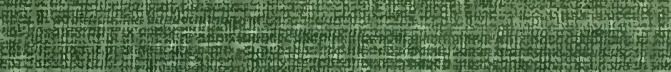
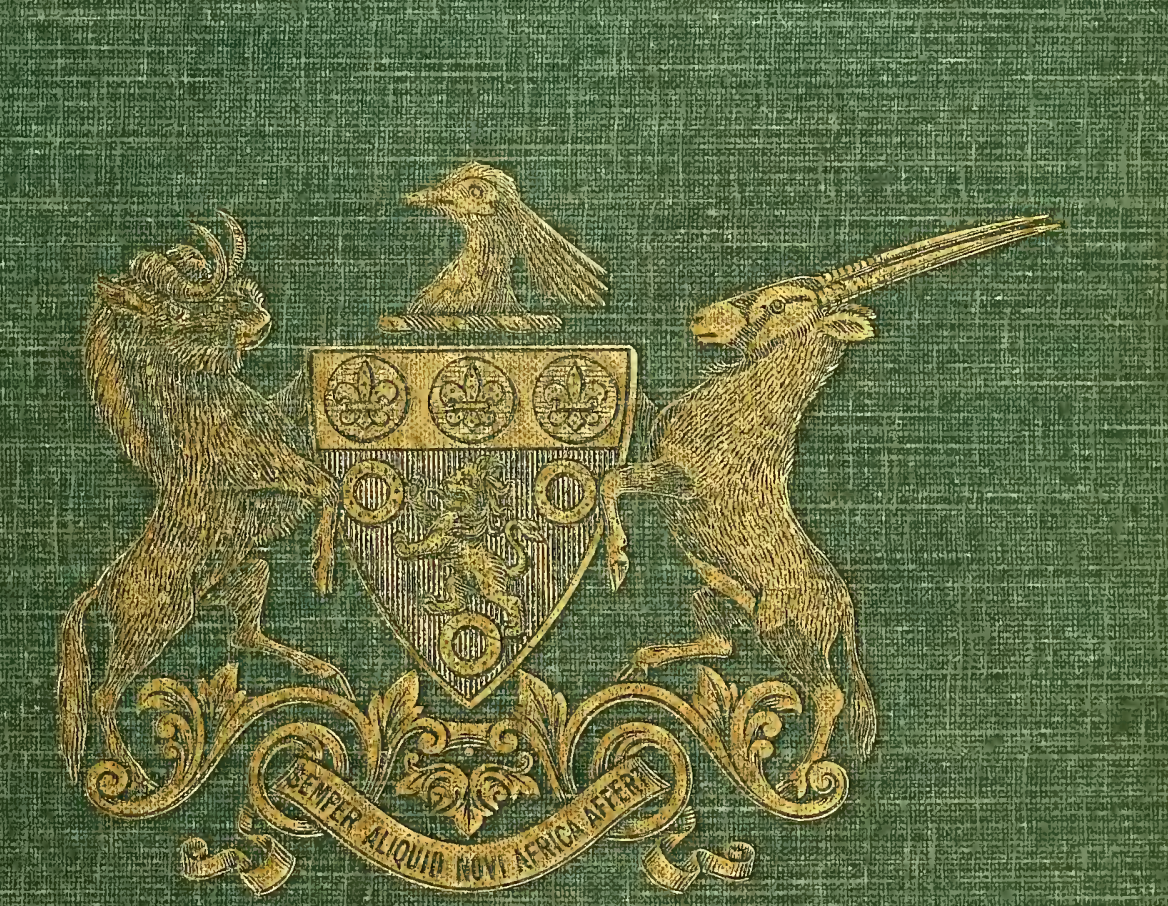

1.

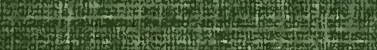




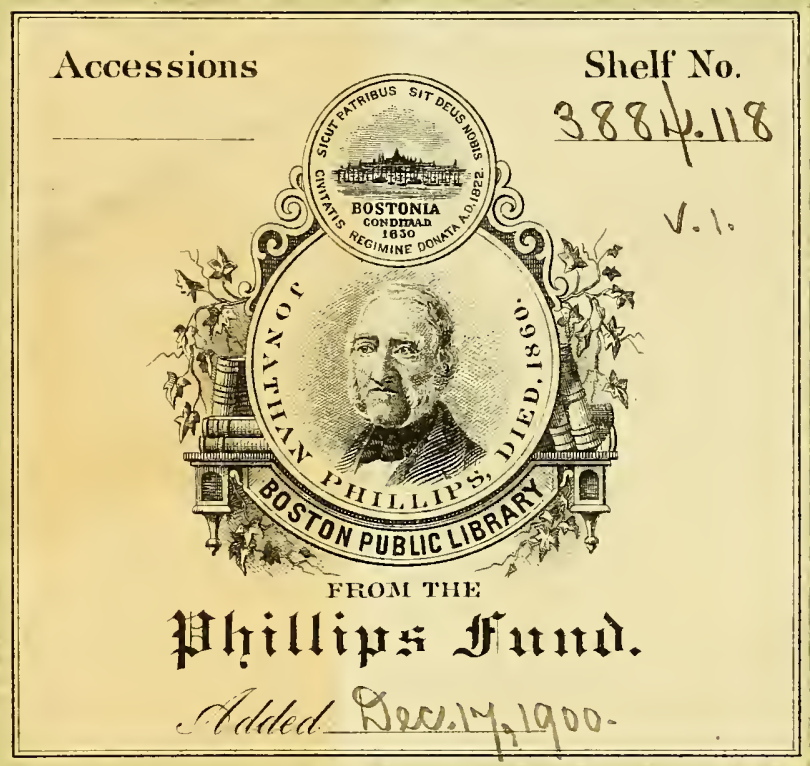




\section{SMAR 28}

BOBAN 21

1902 W JUN 81
TO THE READER.

This book is not in good condition. Please use it carefully.

B,P.L. FORM NO. $403: 9,26,30: 10 \mathrm{M}$. WAN: 
Digitized by the Internet Archive in 2010 with funding from Boston Public Library 


\section{FAUNA OF SOUTH AFRICA}

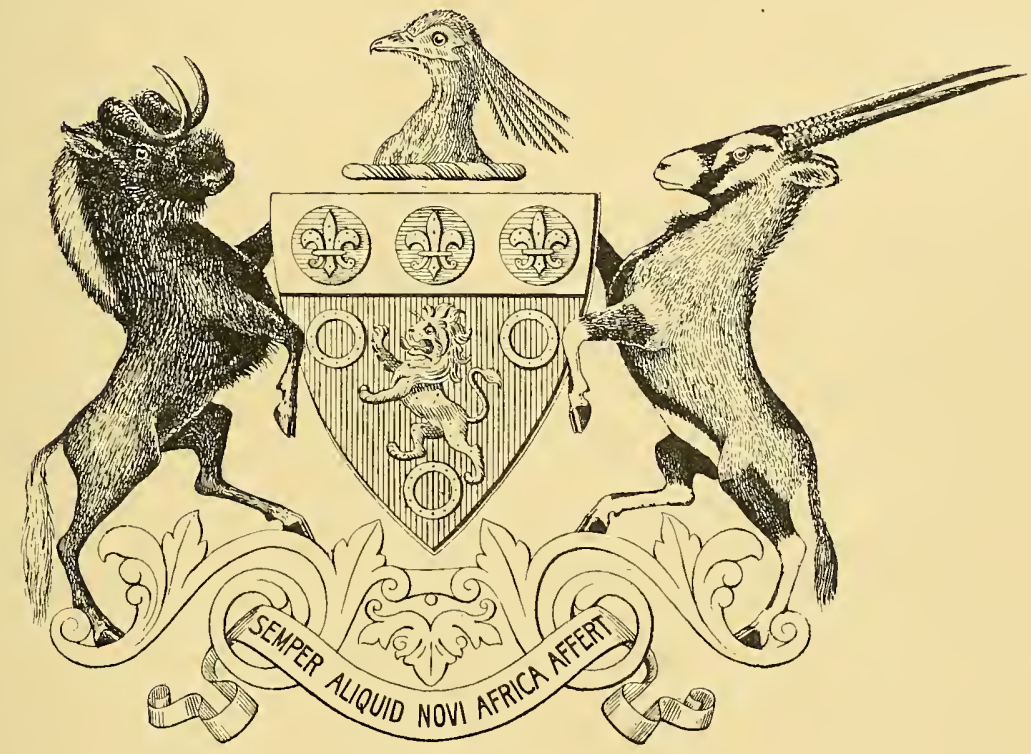

EDITED BY

W. L. SCLATER, M.A., F.Z.S.

Director of the South African Musemn, Cape Town 



\title{
MAMMALS OF SOUTH AFRICA
}

BY

\section{W. L. SCLATER, M.A., F.Z.S.}

Director of the South African Museum, Cape Town

\author{
VOL. I. \\ PRIMATES, CARNIVORA AND UNGULATA. \\ WITH A MAP AND ILLUSTRATIONS
}

\section{ILondon}

R. H. PORTER

7. PRINCES STREET, CAVENDISH SQUARE, W. 


\section{LONDON}

PRINTED BY

JOHN BALE, SONS AND DANIELSSON, LTD.

83-89, GT. TITCHFIELD STREET

w.

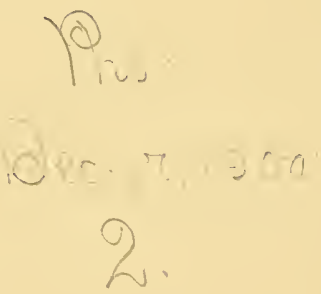

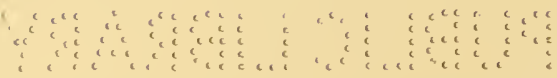

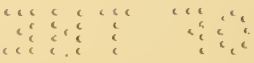


TO

MY WIFE

WHO HAS SHARED AND LIGHTENED MY

LABOURS

I DEDICATE THESE VOLUMES. 



\section{INTRODUCTION.}

IT seems a very remarkable fact, in these days of books and book-making, that except for one very creditable essay published in 1832, by Mr. J. F. Smuts, no one has hitherto attempted to give a complete account of the Mammals of South Africa; and although large numbers of naturalists and sportsmen have visited the country, for the purpose of shooting and collecting, nearly all their energies have been devoted to obtaining so-called "trophies" of the larger animals; while the smaller sorts, among which are many most interesting creatures, have been hitherto almost entirely neglected.

The result of this is that our knowledge of the larger animals such as the antelopes and the carnivores, is fairly complete, while among the rats, bats, and shrews, much still remains to be done.

In the present volumes I have endeavoured to collect together all the information at present available on the subject of Sonth African Mammals. I fear there are a good many omissions and that much revision will be necessary, but my hope is, that the publication of this book may stimulate the energy of many interested in Natural History to collect further material and to record more facts about the life-history of South African animals, for it is the want of specimens, and of information regarding them, that has so much hampered me in my present efforts.

The limits of South Africa, which I have chosen somewhat arbitrarily are the Cunene and Zambesi Rivers on the West and East coasts respectively; on the whole this is a more convenient line than the Tropic of Capricorn, which has 
viii.

sometimes been adopted, or than any fancied line of faunal change.

The Synonymy has been reduced, as far as possible: only references to authors dealing with South Africa have been considered, and a large number of references to the narratives of the older Cape Travellers and to sporting works have been placed under separate headings entitled "Literature."

For the vernacular names in Kaffir or Amaxosa, I am indebted to Mr. W. E. M. Stanford, C.M.G., the Superintendent of native affairs at Cape Town, who is an excellent Kaffir linguist. The descriptions and measurements (which are all in inches), have, unless otherwise stated, all been taken from specimens preserved in the South African Museum, and I have endeavoured to so draw up the former that, with the help of the numerous keys, the ordinary educated individual without special scientific training may be able to understand them, though perhaps this will not always be quite feasible.

In preparing the accounts of the habits of the animals I have necessarily relied on the observations of others. I have endeavoured to compile from what has been already published, and from observations communicated to me by letter and otherwise, a short summary of what is known of the lifehistory of every animal. In the case of many of the smaller forms there is nothing whatever known, and it is here that there is an unbounded field for Nature-lovers throughout South Africa.

Of the illustrations a considerable number have been most kindly lent to me by the Committee of Publications of the Zoological Society of London, to whom I have to return my most sincere thanks. The Publishers of Flower and Lydekker's Mammals have also allowed me the privilege of purchasing a number of clichés of blocks used in that work. The other illustrations have been prepared, under my superintendence, chiefly here in Cape Town, by Miss Ethel Edwards, Mr. Claude Fuller and Mr. and Mrs. C. H. Thompson, to all of whom I am much indebted for their patience and attention to my wants, and although in some cases they have not turned out quite so successfully as I could have wished, yet 
they are careful representations of the animals, and the shortcomings of some of them from an artistic point of view are due chiefly to the inexperience of the artists in making drawings for reproduction in the form of process blocks.

Finally, I must ask my numerous correspondents, both in South Africa and elsewhere, to accept my heartiest acknowledgment for their help, and for the information and the specimens often obtained by them at great inconvenience to themselves, and without which my work would have been still more imperfect; chief among these are Mr. G. A. K. Marshall, of Salisbury, Messrs. H. F. and W. Francis, the late $\mathrm{Mr}$. W. Cloete, of Waterfall, in the Albany Division, Mr. Claude Southey, Dr. C. L. Lindley and Miss Lilian Orpen. To Mrr. Oldfield Thomas and to Mr. W. E. de Winton, of the Natural History Museum in London, and especially to my father, $\mathrm{Mr}$. P. L. Sclater, Secretary of the Zoological Society, I am indebted for constant aid and advice. Mr. Sclater has, furthermore, most kindly undertaken the labour of reading through my proofs for the press.

W. L. SCLATER.

South African Museum, Cape Town, February 13, 1900. 



\section{BIBLIOGRAPHY.}

The following is a list of the more important separate works dealing with South African Mammals referred to in the text, arranged according to the date of publication.

1686. Tachard, Père G. Voyage de Siam des Pères Jesuites, \&c. 2 vols. Paris. 4to.

The second chapter contains an account of the Cape, with allusions to the fauna, illustrated with plates of the Zebra, on p.90, and of the Vache Marine (Hippopotamus), the Rhinoceros and the Cerf du Cap (Hartebeest), on p. 104.

1731. Kolben, P. The Present State of the Cape of Good Hope done into English, by Mr. Medley. 2 vols. London. Svo.

Translation from the German original, published at Nuremberg, in folio in 1719. The second volume contains the earliest list of South African animals.

1763. Caille, Abbé N. L. de la. Journal Historique du Voyage fait au Cap de Bonne Espérance. Paris. $12 \mathrm{mo}$.

The Abbé visited the Cape in $\mathbf{1 7 5 0}$ to make certain astronomical observations; his journal contains descriptions of one or two animals met with during his stay.

1766-68. Linnaens, C. von. Systema Naturae. 3 vols in 4. Ed. duodecima. Stockholm. $8 \mathrm{vo}$.

From the 12th edition of Linnaeus' "System of Nature," binomial nomenclature makes its start.

1766-87. Vosmaer, A. [Collection of descriptions, in Dutch, of various animals, each with a separate title-page and illustrated with a coloured plate]. Amsterdam. 4 to.

The following Cape animals are described chiefly from examples living in the menagerie of the Prince of Orange, viz., Wart Hog (Phacochoerns aethiopicus), Dassie (Procavia capensis), Genet (Genetta tigrina), Kudu (Strepsiceros capensis), Eland (Taurotragus oryx), Gnu (Connochaetes gnu), Giraffe (Giraffa capensis), and Golden Mole (Chrysochloris aurea). 
1774-89. Buffon, Comte de. Histoire Naturelle. Supplément, vols 1-7. Paris. 4to.

A number of South African animals are bere mentioned for the first time; most of the descriptions are based on information sent by Colonel Gordon to Professor Allamand, at Leyden, and reprinted from Allamand's Dutch edition of Buffon's great work.

1775-1810. Schreber. Die Säugethiere. 5 vols. Erlangen. 4 to.

A descriptive work on mammals, not completed by the author but continued after his death by Goldfuss and Wagner.

1776. Masson, F. An Account of Three Journeys from Cape Town into the Southern parts of Africa; undertaken for the Discovery of New Plants towards the Improvement of the Royal Botanical Gardens at Kew. Phil. Trans., 1776, part 1, p. 268.

Mr. Masson was a gardener from Kew who travelled extensively in South Africa between the years 1772 and 1776 . The account of his travels contains a good many references to the larger Cape animals, though none are described at very great lengtb.

1778. Hop, H. Nouvelle description du Cap de Bonne Espérance avec un journal historique d'un voyage de terre fait par ordre du Governeur Feu Mgr. Ryk Tulbagh. Amsterdam. 8vo.

Journal of a journey undertaken in 1761-62 to Little and Great Namaqualand, during which the Giraffe was first met with in South Africa; descriptions of this and other animals from the pens of Professor Allamand and Dr. Klockner of Leyden.

1785. Sparrman, A. A Voyage to the Cape of Good Hope, \&c., from the year 1772 to 1776.2 vols. Dublin. 8vo.

Translation from the original published at Stockholm (8vo, 1783). Sparrman was the earliest trained naturalist who visited South Africa, he travelled along the South Coast as far as the Fish River; his observations are very trustworthy and he added much to our knowledge; a number of Cape animals were described by him for the first time in the Transactions of the Swedish Academy for the years 1778-82.

1789. Paterson, W. A Narrative of Four Journeys into the Country of the Hottentots and Caffraria in the Years 1777, 1778, 1779. London. 4 to.

Notes on journeys made through the eastern and northern parts of the Colony, including the first discovery of the mouth of the Orange River, with Colonel Gordon, and containing references to many animals including the Giraffe, a specimen of which was obtained just to the north of the Orange River.

1790. Vaillant, F. le. Travels from the Cape of Good Hope into the Interior Parts of Africa. Translated by Mrs. Helme. 2 vols. London. 8vo.

1796. Vaillant, F. le. New Travels in the Interior Parts of Africa in the Years 1783, 1784, 1785. 3 vols. London. 8 vo.

The first translated from the 1st edition, published in 4to, at Paris in 1789, the second from the Paris edition, in 8vo, dated l'au 3 (1794-95); accounts of the habits of a good many animals are referred to in these perhaps not wholly trustworthy works. 
1795. Thunberg, C. P. Travels in Europe, Africa and Asia, made between the Years 1770 and 1779. 4 vols. 2nd ed. London. 8vo.

Translation of the original Swedish edition. Vols. 1 and 2 contain the African travels through the Colony to Algoa Bay in the East, and to Calvinia in the North; many incidental accounts of the larger animals are given, afterwards separately published in the "Memoirs of the St. Petersburg Academy," vol. 3 for 1811.

1801-04. Barrow, J. An Account of Travels into the Interior of Southern Africa in the Years 1797, 1798. 2 vols. London. 4to.

A second edition, also in 2 vols., published in 1806. Barrow came out on the staff of Lord Macartney, the first English Governor, and travelled all over the Colony; he makes many references to the animals met with and their habits.

1804-05. Daniell, S. African Scenery, being Illustrations of the Animals, \&c. Plates 1-30. London, oblong folio.

Sketches of the artist who accompanied Messrs. Truter and Somerville on their journey to the north of the Orange River in 1801 (see below, Barrow).

1806. Barrow, J. A Voyage to Cochin China, \&c., to which is annexed an Account of a Journey made in the Years 1801, 1802, to the Residence of the Chief of the Booshuana Natives. London. 4to.

The appendix is a narrative by Messrs. P. J. Truter and William Somerville, of one of the earliest journeys north of the Orange River as far as Latakoo, near Kuruman in Bechuanaland. The Pallah (Aepyceros melampus), the Kokoon or Blue Wildebeest (Connochlaetes taurinus), the "new quagga" (Equus burchelli), and the Takheitse or Roan (Hippotragus equinus) are all met with and described, though their introduction to scientific nomenclature did not take place till later. The animals were mostly figured by Daniell.

1812-15. Lichtenstein, H. Travels in Southern Africa in the Years 1803, 1804, 1805 and 1806. Translated from the original German, by Anne Plumptre. 2 vols. London. 4to.

Translation from the German edition published in 8vo at Berlin in 1811 . Narrative of travels through the Colony and also to Bechuanaland. Notes on several animals are given and also a scientific description and name for the Pallah (Aepyceros melampus).

1817. Burchell, W. A List of Quadrupeds brought by Mr. Burchell from South Africa and Presented by him to the British Museum on the 30th of September, 1817. Pamphlet. London. 8vo.

1820. Daniell, W. Sketches Representing the Native Tribes, Animals and Scenery of Southern Africa. 48 pls. London. Long 8 vo.

A further series of uncoloured engravings by Samuel Daniell (cf. 1804).

1820-22. Desmarest, A. G. Mammalogie ou Description des espèces des Mammifères, 2 vols. Paris. 4to.

A complete descriptive catalogue of the Mammals then known; many of the South African animals collected by Delalande are here described for the first time. 
xiv.

1822. Burchell, W. J. Travels in the Interior of Southern Africa. 2 vols. London. 4to.

Burchell (born 1781, died 1863), arrived at the Cape in 1810 and travelled north as far as Litakun (near Kuruman); he was a most skilful and welltrained zoologist and botanist, and his observations are all accurate and methodical; he discovered and named the Sassaby (Damaliscus lunatus) and a small Wild Cat (Felis nigripes); he also gave a name to the blue Wildebeest (Connochaetes taurinus) and the Blesbok (Damaliscus albifrons), and discriminated the Zebra, to which later Gray gave his name (Equns burchelli).

1826. Smith, A. A Descriptive Catalogue of the South African Museum. Part 1. Mammalia. Cape Town. 8vo.

A descriptive list of the Mammals contained in the collections brought together by Dr., afterwards Sir Andrew Smith, to form the first South African Museum, instituted in June, 1825, by the order of His Excellency Lord Charles Henry Somerset, the then Governor; the collections were for many years in the care of the South African Institution, and subsequently handed over to form the nucleus of the South African Museum, as refounded in 1857.

1827-34. Lichtenstein, H. Darstellung neuer oder wenig bekaunter Säugethiere. Berlin. Folio.

This work contains descriptions of eighteen South African animals, several of which are described as new species though now relegated to synonomy.

1827. Brants, A. Het Geslacht der Muizen door Linnaeus op-gesteldt met eene plat. Berlin. 8vo.

A monograph on the Nuridae containing the earliest descriptions of the following Cape animals:-Georychus caecutiens, Otomys irroratus, Dendromys mesomelas and Mus colonus.

1832. Smuts, J. Dissertatio Zoologica, enumerationem Mammalium Capensium continens. Tribus tabulis adjunctis. Leyden. 4to.

This is the first and in fact the only work dealing with the Mammals of the Cape. Very careful descriptions are given of all the animals, 108 in number. Vespertilio tricolor, Sorex (now Myosorex) varius, Mus dolichurus and Manis temmincki, are described for the first time, others, also described as new, have since been shown to be synonymous with previously described species.

1835. Steedman, A. Wanderings and Adventures in the Interior of Southern Africa. 2 vols. London. 8 vo.

Account of travels, chiefly in the Eastern Provinces, and as far as Griquatown in Griqualand West, whither he accompanied Sir A. Smith; chapter v. of the second volume is devoted to Natural History, and an account of the Waterbuck (Cobus ellipsiprymnus) first obtained by the author is there given.

1835. Moodie, J. W. D. Ten Years in South Africa. 2 vols. London. 8vo.

Incidental notes on the habits and distributiou of many animals in Swellen. dam and Albany between the years 1830-35 are here given.

1836. Smith, A. Report of the Expedition for Exploring Central Africa from the Cape of Good Hope. Cape Town. 8vo.

In an appendix are described the new species of mammals and birds met with during the expeditiou, of which the route extended through Basutoland and 
Bechuanaland, as far as Moselekatse's capital, in what is now the Western Transvaal. The following are the species described for the first time:-Galago moholi, Macroscelides intufi and M. brachyrhynchus, Mus marikquensis, Mus coucha, Mus lehochla, Gerbillus paeba, Gerbillus brantsi and Funisciurus cipapi.

1838. Harris, W. C. Narrative of an Expedition into Southern Africa during the Years 1836 and 1837. 1st edition. Bombay. 8vo.

Second edition published in London, 1839 ; account of a shooting expedition undertaken by the author to the country of Moselekatze, the Matabele Chief, in what is now the Rustenburg District of the Transvaal; accounts of many larger animals are given and also of the discovery of the Sable Antelope (Hippotragus niger).

1840. Harris, W. C. Portraits of the Game and Wild Animals of Southern Africa. 30 plates. London. Folio.

Illustrations of nearly all the larger animals of South Africa drawn from the author's sketches, and accompanied by rather grandiloquent and flowery descriptions.

[1847]. Delegorgue, A. Voyage dans l'Afrique Australe. 2 vols. Paris. 8vo.

Account of shooting expeditions in Natal and Zululand, and of a journey to the Magaliesberg, now in the Rustenburg district of the Transvaal, from 1838 to 1842, with many observations and reflections on Natural History.

1848. Methuen, H. H. Life in the Wilderness, or Wanderings in South Africa. 2nd ed. London. 8vo.

First edition published in 1846. Account of a journey as far as the junction of the Limpopo and Marico rivers, now in the north-western part of the Transvaal, with observations on the larger animals and woodcuts of their heads.

1849. Smith, Sir A. Illustrations of the Zoology of South Africa. Vol. 1, Mammalia. 53 plates. London. 4 to.

Descriptions, with coloured plates, of various South African animals chiefly collected by the author during his journey into the interior (cf. 1836). Many new species are described, and the work constitutes by far the most valuable contribution up to that time, to our knowledge of South African Zoology.

1849. Angas, C. F. The Kaffirs, illustrated in a series of drawings, \&c. London. Folio.

Plate 29 illustrates a new Antelope, the Inyala (Tragelaphus angasi), discovered and described by the author from the neighbourhood of St. Lucia Bay in Zululand.

1850. Gray, J. E. Gleanings from the Menagerie and Aviary at Knowsley Hall. Hoofed Quadrupeds. (Printed for Private Distribution). Knowsley. Folio.

A series of plates, coloured and uncoloured, from drawings by Mr. Waterhouse Hawkins, of animals living in the Menagerie of the Thirteenth Earl of Derby, accompanied by descriptive letterpress by Dr. Gray; many South African species are delineated. 
1852. Peters, W. C. H. Naturwisseuschaftliche Reise nach Mossambique in den Jahren 1842 bis 1848 ausgeführt. Zoologie I. Säugethiere. Fiftyfour plates. Berlin. Folio.

A classic work on the Fauna of the Lower Zambesi Valley; many of the new species herein described have subsequently been found further south, well within our limits, such are Versperugo nanus, Chrysochloris obtusirostris, Funisciunus palliatus, Gerbillus leucogaster, Saccostomus campestris, Golunda fallax, Hystrix africae-australis, Bubalis lichtensteini.

1855. Cumming, R. G. Five Years of a Hunter's Life in the Far Interior of South Africa. 2 vols. New ed. London. Small 8vo.

First edition published in 1850. Description of hunting trips extending as far northwards as the junction of the Shashi and the Limpopo in 1843-49, with accounts of the habits and distribution of most of the larger game; a very large number of Lions and Elephants were shot and a new variety of the Bushbuck was found on the Limpopo and named "Antilopus" roualeyni.

1856. Andersson, C. J. Lake Ngami. London. 8vo.

Account of the author's travels in Damara, Ovampo, and Ngami-land, with notices of the habits of the larger animals met with.

1857. Livingstone, D. Missionary Travels and Researches in South Africa, \&c. London. 8vo.

A history of Dr. Livingstone's earlier journeys from 1842, when Lake Ngami was discovered; various Natural History notes are interspersed; the Lechwe (Cobus lechec), the Puku (Cobus vardoni), the Sitatunga or Nakong (Tragelaphus selousi) and Livingstone's Eland (Taurotragus livingstonii) were all met with for the first time.

1862. Layard, E. L. Catalogue of the Specimens in the Collection of the South African Museum. Part 1, MLammalia. Cape Town. Small 8vo.

Two-hundred and twenty-three' species, both South African and exotic, are enumerated; many of the specimens are still retained, but a good many have been replaced by better preserved examples.

1863. Baldwin, W. C. African Hunting from Natal to the Zambesi from 1852-60. London. 8vo.

Account of hunting excursions in Zululand and through the Transvaal to Lake Ngami and the Zambesi, with notices of many of the larger animals.

1863. Grout, L. Zululand, or Life among thé Zulu Kaffirs. London. 8vo.

A chapter is devoted to the animals of Natal and Zululand and the Zulu names are given.

1864. Baines, T. Explorations in South-West Africa. London. 8vo.

Account of a journey from Walfisch Bay in Damaraland, via Lake Ngami, to the Victoria Falls, with notes and other particulars of the larger animals met with.

1868. Chapman, J. Travels in the Interior of South Africa. 2 vols. London. 8 vo.

Account of Wanderings between Natal, Lake Ngami, the Victoria Falls and Walfisch Bay during the years 1849-61; contains notes on the habits and distribution of some of the larger animals. 
1873. Andersson, C. J. The Lion and the Elephant. London. 8vo.

The habits and hunting of the two animals as observed in South Africa by the author.

1875. Drummond, The Hon. W. H. The Large Game and Natural History of South and South-East Africa. Edinburgh. 8vo.

The author's experiences were chiefly in Natal and Zululand, and a good many of the animals found there are here commented on.

1878. Dobson, G. E. Catalogue of the Chiroptera in the Collection of the British Museum. London. 8vo.

This work contains full descriptions of all the Bats of the world, and our knowledge of South African species is mostly founded on the information therein contained.

1878-83. Elliot, D. G. A Monograph of the Felidae, or Family of the Cats. London. Folio.

A complete monograph illustrated with fine coloured plates.

1881. Holub, E. Seven Years in South Africa (1872-79). Translated by Ellen E. Frewer. 2 vols, London. 8vo.

Translation of the German edition published at Vienna in 1880; contains notes on various animals met with during his journeys extending as far as the Victoria Falls and Sesheke on the Zambesi.

1882-90. Dobson, G. E. A Monograph of the. Insectivora, Systematic and Anatomical. Parts 1-3, fasc. 1. London. 4 to.

An unfinished work containing a monograph of the Golden Moles, a family of considerable importance in South Africa.

1886. Farini, G. A. Through the Kalahari Desert. London. 8vo.

An appendix contains a list of Kalahari Mammals.

1888-93. Theal, G. McC. History of South Africa. 5 vols. London. 8vo.

Many scattered references to the South African Fauna are to be found in these pages.

1889. Bryden, H. A. Kloof and Karoo. London. 8vo.

Contains special chapters on some of the Game animals, such as the Klipspringer, Vaal Rhebok, Zebra, together with a valuable account of the past distribution of the larger animals of the Colony.

1889. True, F. W. Contributions to the Natural History of the Cetaceans, A Review of the Family Delphinidae. Bulletin of the United States National Museum, No. 36. Washington. 8vo.

A complete account of the members of the Dolphin family.

1890. Mivart, St. G. Monograph of the Canidae. London. 4to.

A monograph illustrated with plates of all the South African species of Dogs, Foxes and Jackals.

1890. Reuvens, C. L. Die Myoxidae oder Schlaefer. Leyden, 4to.

A monograph of the Dormice, with the description of a new species from Damaraland. 
xviii.

1890. Selous, F. C. A Hunter's Wanderings in Africa. 2nd edition. London. 8vo.

First edition published in 1881. The greater part of the book is devoted to hunting reminiscences in Mashonaland and north of the Zambesi, with many incidental references to the habits of the animals met with; two valuable chapters on the Antelopes and Rhinoceros are reprinted from the Zoological Society's "Proceedings." The whole is illustrated with figures of the heads of the numerous South African Antelopes.

1890. Martin, Annie. Home Life on an Ostrich Farm. London. 8vo.

Contains notes on the habits of many of the animals and birds met with on Karoo, during a residence for some time in the eastern part of the Colony.

1892. Nicolls, J. A., and Eglington, E. The Sportsman in South Africa. London. 8vo.

An account of the game animals and birds of South Africa, with descriptions, native names, habits and distribution, derived partly from personal observation and partly from compilation. The heads of all the Antelopes are figured in a series of twelve plates.

1892. Moseley, H. N. Notes by a Naturalist on the Challenger. 2nd edition. London. 8vo.

First edition published in 1879; chapter vi. contains an account of residence at, and observation on the Fauna of, the Cape Peninsula, during the stay of the Challenger in Simon's Bay.

1892. Distant, W. L. A Naturalist in the Transvaal. London. 8vo.

Contains scattered notes on some of the Mammals, and (on p. 159) a list of those observed near Pretoria.

1893. Selous, F. C. Travel and Adventure in South-east Africa. London. 8vo.

Further hunting reminiscences with scattered notes on the habits of the larger animals.

1893. Bryden, H. A. Gun and Camera in Southern Africa. London, 8vo.

Account of a residence in British Bechuanaland, and of a trip to the Botletli River; an excellent account of Giraffe shooting is given; one chapter deals with the distribution of the larger game animals of Bechuanaland and the Protectorate.

1893. Lydekker, R. Horns and Hoofs, or Chapters on Hoofed Animals. London. 8vo.

Short descriptions and notes on the various members of the families Bovidae, Cervidae, Suidae and Rhinocerotidae, illustrated with many figures in the text.

1894. Oswell, W. C., Jacksou, F. J., Selous, F. C., and others. Big Game Shooting. The Badminton Library. 2 vols. London. 8vo.

Accounts of several of the large South African game animals, with reminis. cences by Mr. Oswell, Livingstone's companion in his early journeys. 
1894-1900. Sclater, P. L., and Thomas, O. The Book of Antelopes, 4 vols. London. 4 to.

This work contains full descriptions and synonomy of all the known species of Antelopes, together with accounts of their habits and distribution. Almost every species is illustrated by a coloured plate, besides numerous woodcuts of heads and horns.

1895. Millais, J. G. A Breath from the Veldt. London. Folio.

Contains accounts of the Game animals met with and shot on a hunting excursion from Capetown through the Transvaal bushveld to south-east Mashonaland; the special value of the book consists in the drawings and sketches which were nearly all done from the live or only just killed animals, and not from stuffed specimens, as is so frequently the case; the animals most fully dealt with are the Springbok, Kudu, Sable, and Wildebeest, both Black and Blue.

1895. Matschie, P. Die Säugethiere Deutsch-Ost-Afrikas. Berlin. 8vo.

An account of the Mammals of German East Africa, with many illustrations and much incidental information about South African species.

1896. Kirby, F. V. In Haunts of Wild Game. Edinburgh. 8vo.

An account of hunting the large Game animals found in the bushveld of the Eastern Transvaal and adjoining Portuguese territory; an appendix gives a useful list of the animals met with, together with their vernacular names, distribution and habits.

1897. Bryden, H. A. Nature and Sport in South Africa. London. 8vo.

Chapters are devoted to many of the larger and more interesting South African animals, their history, habits and distribution.

1898. Gibbons, A. St. H. Exploration and Hunting in Central Africa. London. 8vo.

In an appendix on p. 394, is a list of the Game animals of Barotseland with notes on their habits and distribution.

1898-99. Catalogus Mammalium tam viventium quam fossilium. 2 vols. New edition. Berlin. 8vo.

A most useful catalogue with the synonomy and distribution of all the species of Mammals hitherto described.

1899. Bryden, H. A. (edited by). Great and Small Game of Africa. London. 4 to.

This work contains descriptions and illustrations of all the larger African animals, the South African portion contains contributions by Kirby, Selous, Bryden, Rendall and Neumann.

1899. Kirby, F. V. Sport in East Central Africa. London. 8vo.

A zoological appendix, contains some notes on Mammals met with, especially in the Portuguese districts lying between the Zambesi and Beira. 



\section{A BBREVIATIONS.}

The following are the abbreviations used for the more important journals quoted in the synonymy:-

Ann. kk. Hofmus. .....Annalen des k. k. naturhistorischen Hofmuseums, 14 vols. 1886-99. Vienna. 8vo.

Ann. Mag. N. H. , .....Annals and Magazine of Natural History. 124 vols. 1838-99. London. 8vo.

Ann. Mus............Annales du Muséum d'Historie Naturelle, 20 vols. 1802-13. Paris, 4to.

Ann. S, A. Mus. ....,.,Annals of the South African Museum. 1 vol, 1898-99. Cape Town. 8vo.

Ann. Sci. Nat. .........Annales des Sciences Naturelles, Zoologie et Palaeontologie. 162 vols. 1824-99. Paris. 8vo.

Archiv. f. Naturg. .... Archiv für Naturgeschichte. 65 vols. 1835-99. Berlin. Svo.

Bericht Akad., Berlin...Bericht üher die zur Bekanntmachung geeigneten Verhandlungen der königlich-preussischen Akademie der Wissenschaften zu Berlin. 20 vols. 1836-55. Berlin. 8vo.

Bull. Soc. Philom. ....Bulletin de la Société Philomatique de Paris. 49 vols. 1791-99. Paris. 8vo.

Charlesw. Mag. N. H... Magazine of Natural History; new series by Edward Charlesworth. 4 vols. 1837-40. London. 8 vo.

Jorn. Sci. Lisb........ Jornal de Sciencias mathematicas, physicas et naturaes publicado sob os auspicios da Academia real das Sciencias de Lisboa. 30 vols. 1868-99. Lisbon. 8vo.

K.Vetensk. Akad.Handl.Kongliga Svenska Vetenskaps Akademiens Handlingar. 138 vols. 1739-91. Stockbolm. 8vo and 4to.

Le Natur. ...........Le Naturaliste. 21 vols. 1879-86. Paris. 4to.

Mag. nat. Fr. Berl...... Magazin der Gesellschaft naturforschender Freunde zu Berlin (c. f. S. B. nat. Fr. Berl.). 8 vols. 1807-18. Berlin. 4to.

M. B. Akad. Berlin.....Monatsherichte der königlich-preussischen Akademie der Wissenschaften zu Berlin. 26 vols. 1856-81. Berlin (c. f. Bericht Akad. Berlin).

Mem. Mus. Hist. Nat.. Mémoires du Muséum d'Histoire Naturelle. 20 vols. 1815-32. Paris. 4to. 
N. Arch. Mus. ........ Nouvelles Archives du Muséum d'Histoire Naturelle. 35 vols. 1865-99. Paris. 4to.

N. Act. Ups. .......... Nova Acta Regiae Societatis Scientiarium Upsalensis. 14 vols. 1733-50. Upsala. 4 to.

Notes Leyd. Mus. .... Notes from the Royal Zoological Museum of the Netherlands at Leyden. 21 vols. 1879-99. Leyden. 8vo.

Nov. Zool. ............ Novitates Zoologicae. 6 vols. 1894-99. Tring. 8vo.

Ofvers. K. Vet. Akad. Öfversigt af $\mathrm{K}$. Vetenskaps-Akademiens Forhandlingar. Forh. ............56 vols. 1845-99. Stockholm. 8vo.

Proc. Zool. Soc. ......Proceedings of the Zoological Society of London. 67 vols. 1832-99. London. 8vo.

Rev. Mag. Zool. .....Revue et Magasin de Zoologie. 30 vols. 1849-79 . Paris. 8vo.

S. Afr. Quart. Journ. .. South African Quarterly Journal. 2 vols. 1829-35. Cape Town. 8vo.

S. B. nat. Fr. Berlin .. Sitzungsberichte der Gesellschaft naturforschender Freunde zu Berlin. 30 vols. 1860-99. Berlin. 4to. and $8 \mathrm{vo}$.

Trans. Zool. Soc. ...... Transactions of the Zoological Society of London. 15 vols. 1885-99. London. 4to.

Zool. Gart........... Der Zoologische Garten. 30 vols. 1860-99. Frankfurta-M. 8 vo.

Zool. Jahrb. .........Zoologische Jahrbïcher. 36 vols. 1886-99. Jena. 8vo. Zool. Journ. .........Zoological Journal. 5 vols. 1824-35. London. 8vo. Zoologist. ..........The Zoologist. 57 vols. 1843-99. London. 8vo. 


\section{LIST OF ILLUSTRATIONS IN THE TEXT.}

Fig 1 Cercopithecus lalandii, mother and young ............ PAGI

", 2 Cercopithecus samango ................................... 10

" 3 Side view of the skull of Papio porcarius ............. 13

" 4 Papio cynocephalus ................................... 17

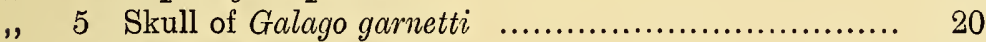

" 6 Skull of Galago moholi ................................ 21

" 7 Galago moholi.......................................... 22

" 8 The right half of the hinder part of the base of the cranium of the Wolf (Canis lupus) ................ 25

9 Left half of the palate and the lower jaw of Felis caffra .............................................. 28

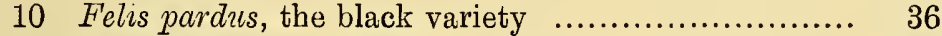

11 Felis nigripes ........................................ 41

12 Genetta tigrina, left half of palate ..................... 53

13 Sole of the hind foot of Genetta tigrina ................ 54

14 The small spotted Genet, Genetta felina ............. 56

15 Left half of palate and lower jaw of Herpestes galera 59

16 The Small Grey Mungoose (Herpestes pulverulentus) 65

17 Skull of Rhynchogale melleri ....................... 70

18 Left half of palate and lower jaw of Suricata tetradactyla ...................................... $\quad 76$

19 Suricata tetradactyla............................... 78

20 Palate and lower jaw of Proteles cristatus showing the rudimentary molars ......................... $\quad 79$

21 Proteles cristatus ..................................... 81

22 Skull and left half of palate of Hyacna crocuta........ 84

23 Hyaena brunnea......................................... 86

24 Skull of Vulpes chama .............................. 97

25 Skull of Otocyon megalotis .......................... 99

26 Otocyon megalotis ..................................... 100

27 Skull of Lycaon pictus ............................. 102

28 Lycaon pictus...................................... 103 
Fig. 29 Left half of palate and lower jaw of Mellivora ratel... 109

„30 Mellivora ratel .................................... 111

„, 31 Palatal view of skull and lower jaw of Zorilla striata 113

,, 32 Skull of Poecilogale albinucha ..................... 115

,. 33 Poccilogale albinucha................................ 116

" 34 Skull of Arctocephalus pusillus....................... 119

", 35 Arctocephalus pusillus ............................. 121

, 36 Skeleton of the right fore feet of the pig and the buffalo (Bos caffer), to show the modification of the Artiodactyle limb.

, 37 Stomach of a ruminant opened to show its internal

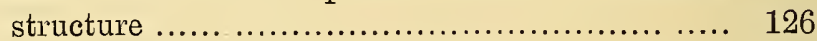

38 Skull and horns of Bubalis lichtensteini $\delta$............. 130

39 The Red Hartebeest (Bubalis caama) .............. 132

40 Lichtenstein's Hartebeest (Bubalis lichtensteini)..... 135

41 The Bontebok (Damaliscus pygargus)................. 139

42 The Blesbok (Damaliscus albifrons) ................ 142

43 Skull and horns of the supposed hybrid between the

Red Hartebeest and the Sassaby ................. 145

44 Young Black Wildebeest, eight months old............. 149

45 Horns of Black Wildebeest, eleven weeks old and nineteen months old ........................... 152

46 Head of the Duiker (Cephalophus grimmi)............ 159

", 47 The Klipspringer (Oreotragus saltator) .............. 167

, 48 Fore leg of the Oribi (Ourebia scoparia) to show the knee tufts...................................... 171

49 Skull of Nesotragus livingstonianus $\delta$................ 179

, 50 Head of the Damaraland Dik-dik (Madoqua damarensis $)$................................... 182

51 Head of the Water-buck (Cobus ellipsiprymnus)..... 186

52 Horns of the Puku (Cobus vardoni)................... 192

53 Head of the Rooi Rhebok (Cervicapra fulvorufula) o 198

54 Hind feet of Aepyceros melampus to show the glandular tufts on the cannon bones ............. 203

55 Head of the male Pallah (Aepyceros melampus)......... 205

56 Side view of skull and horns of Antidorcas euchore 208

57 Head of the Roan Antelope (Hippotragus equinus) ... 218

58 Head of the Sable Antelope (Hippotragus niger) ..... 222

59 The Gemsbok (Oryx gazella) ........................ 226

60 Skull and horns of the Inyala (Tragelaphus angasi)... 236

61 Skull and horns of the Sitatunga (Tragelaphus selousi) 238

62 Skull and horns of the Kudu (Strepsiceros capensis)... 243

". 63 Head of a male Eland (Taurotragus oryx)............ 249 
", 66 Head of the Southern Giraffe (Giraffc capensis) ...... 262

" 67 Skull of Hippopotamus amphibius .................... 266

", 68 The Hippopotamus (Hippopotamus amphibins) $\quad$..... 269

" 69 The Bosch-vark (Potamochoerus choeropotamus) ...... 275

" 70 Skull of Phacochoerus aethiopicus ................... 277

" 71 Right upper molar of Phacochoerus aethiopicus ..... 277

", 72 Right fore-feet of Rhinoceros simus and Equus burchelli to show the modifications of the Perissodactyle limb .............................................. 281

, $73 \quad$ Skull of Equus burchelli .............................. 283

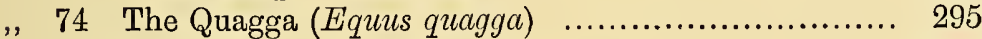

" 75 Skull of Rhinoceros simus........................... 297

" 76 Upper molar of Rhinoceros simus ................... 298

, 77 Skull, side view, and left half of palate of Procavia capensis ............................................. 309

, 78 The Dassie (Procavia capensis) ..................... 312

"79 Right fore-foot of an African Elephant (Elephas africanus), to show the modification of the Proboscidian limb .................................

", 80 Grinding surface of a partially worn right upper molar of the African Elephant (Elephas africa$m u s$ ), to show lozenge-shaped species between the successive enamel plates 



\section{SYSTEMATIC INDEX.}

\section{Order Primates}

Suborder ANTHROPOIDEA

Family Cercopithecidae

1. Cercopithecus lalandii. The Vervet .. .. ..

2. Cercopithecus pygerythrus. The Mozambique MTonkey ..

3. Cercopithecus samango. The Samango Monkey .. $\quad$.. 9

4. Cercopithecus albigularis. Sykes' Monkey . . $\quad$. 11

5. Papio porcarius. The Chacma $\begin{array}{lllll}\text { or Baboon } & . & \text {.. } & \text {.. } & 13\end{array}$

6. Papio cynocephalus. The Yellow Baboon .. $\quad$. 16

Suborder LEMUROIDEA

Family Lenuridae

7. Galago garnetti. Garuett's $\begin{array}{lllll}\text { Lemur } & \text {. } & \text {.. } & \text {.. } & 19\end{array}$

8. Galago moholi. The Moholi Lemur . 20

\section{Order Carnixora}

\section{Suborder FISSIPEDIA}

\section{Division AELUROIDEA}

\section{Family Felidae}

9. Felis leo. The Lion .. 29

10. Felis pardus. The Leopard 34

11. Felis serval. The Serval $\begin{array}{llllll}\text { Cat } & \text {.. } & \text {.. } & \text {.. } & \text {.. } & 38\end{array}$

12. Felis nigripes. The Blackfooted Wild Cat $\quad . \quad$.. 40
14. Felis caracal. The Caracal 44

15. Cynaelurus jubatus. The Hunting Leopard .. $\quad$.. 46

Family Viverridae

16. Viverra civetta. The Civet $\begin{array}{llllll}\text { Cat } & \text {. } & \text {.. } & \text {.. } & \text {.. } & 51\end{array}$

17. Genetta tigrina. The LargeSpotted Genet .. .. 53

18. Genetta felina. The SmallSpotted Genet . . . 55

19. Genetta senegalensis. The Senegal Genet .. . . 57

20. Genetta rubiginosa. The Rusty-spotted Genet .. 58

21. Herpestes caffer. The Large Grey Mrungoose $\quad$. $\quad$.. 60

22. Herpestes gracilis $\ldots \quad \ldots 61$ a, subsp. typicus. The Slender Mungoose $\quad$. $\quad$. . 62 b, subsp. badius. The Ruddy Mungoose $\quad$. $\quad$.. $\quad$.. 62

23. Herpestes galera. The Water Mungoose $\quad . \quad$.. $\quad$.. 63

24. Herpestes pulverulentus. The Small Grey Mungoose. . 65

25. Herpestes punctatissimus. The Pale Mungoose .. . . 66

26. Herpestes albicauda. The White-tailed Mungoose .. 66

27. Herpestes grandis. The Giant Mungoose $\quad$. $\quad$.. 67

28. Helogale parvula. Wahlberg's Mungoose $\quad$. $\quad$. 68

29. Rhynchogale melleri. Meller's Mungoose $\quad$. $\quad$. 71 
30. Crossarchus fasciatus. The Banded Mungoose .. . . 72

31. Cynictis penicillata. The Bushy-tailed Meerkat .. 74

32. Cynictis selousi. Selous' $\begin{array}{lllll}\text { Meerkat } & \text {.. } & \text {. } & \text {.. } & 75\end{array}$

33. Suricata tetradactyla. The Slender-tailed Meerkat .. 76

Family Protelidae

34. Proteles cristatus. The Aard Wolf .. $\quad$.. $\quad$.. $\quad$. 80

Family Hyaenidae

35. Hyaena brunnea. The Brown Hyaena or Strand Wolf .. $\quad . . \quad$.. ..

36. Hyaena crocuta. The Spotted Hyaena or Tiger Wolf .. $\quad . . \quad$.. $\quad . .87$

\section{Division CYNOIDEA}

Family Canidae

37. Canis mesomelas. The Blackbacked Jackal .. ..

38. Canis adustus. The Sidestriped Jackal $\quad$. $\quad$.. 95

39. Vulpes chama. The Silver Fox .. $\quad$.. $\quad$.. $\quad$.. 98

40. Otocyon megalotis. Delalande's Fox .. .. ..

41. Lycaou pictus. The Cape Hunting Dog or Wilde $\begin{array}{lllll}\text { Honde } & \text {.. } & \text {. . } & 102\end{array}$

\section{Division ARCTOIDEA}

\section{Family Mustelidae}

42. Lutra capensis. The Cape $\begin{array}{lllll}\text { Otter .. } & \text {. } & \text {.. } & \text {.. } 107\end{array}$

43. Lutra maculicollis. The Spotted-necked Otter _. 108

44. Mellivora ratel. The Ratel 110

45. Zorilla striata. The Striped Muishond .. $\quad$. $\quad$.. 113

46. Poecilogale albinucha. The Snake Muishond .. . 115
Suborder PINNEPEDIA

Family OtaRIIDAe

47. Arctocephalus pusillus. The Cape Sea-Lion . 120

Order Ungulata

Suborder ARTIODACTYLA

Division PECORA

Family Bovidae

Subfamily Bubalinae

48. Bubalis caama. The Red Hartebeest .. .. .. 131

49. Bubalis lichtensteini. Lichtenstein's Hartebeest . . 134

50. Damaliscus pygargus. The Bontebok $\quad$. $\quad$. . $\quad$. 137

51. Damaliscus albifrons. The Blesbok $\quad$. $\quad$.. $\quad$. 141

52. Damaliscus lunatus. The Sassaby $\quad$. $\quad$. $\quad$.. 144

53. Connochaetes gnu. The Black Wildebeest or Whitetailed Gnu .. $\quad$.. $\quad$.. 148

54. Connochaetes taurinus. The Blue Wildebeest or Brindled Gnu . . $\quad$. . . . . . 152 Subfamily Cephalophinae

55. Cephalophus grimmi. The $\begin{array}{lllll}\text { Duiker } \quad \text {. } & \text {. } & \text {.. } 157\end{array}$

56. Cephalophus natalensis. The Red Duiker .. . . . . 161

57. Cephalophus monticola. The Blue Duiker .. $\quad$.. 163

Subfamily Neotraginae

58. Oreotragus saltator. The Klipspringer ..• .. .. 166

59. Ourebia scoparia. The

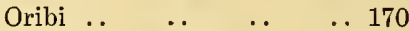

60. Raphicerus campestris. The Steenbok $\quad$. $\quad$. $\quad$. 173

61. Raphicerus melanotis. The $\begin{array}{lllll}\text { Grysbok } & \text {. } & \text {. } & \text {.. } 176\end{array}$ 
62. Nesotragus livingstonianus.

Livingstone's Antelope . 179

63. Madoqua damarensis. The

Damaraland Dik-dik _. 182

\section{Subfamily Cervicaprinae}

64. Cobus ellipsiprymnus. The Waterbuck .. .. .. 185

65. Cobus leche. The Lechwe.. 189

66. Cobus vardoni. The Puku.. 191

67. Cervicapra arundinum. The Reed-Buck .. .. .. 194

68. Cervicapra fulvorufula. The Rooi Rhẹbok _. .. 197

69. Pelea capreolus. The Vaal Rhebok .. .. .. 200

\section{Subfamily Antilopinae}

70. Aepyceros melampus. The Pallah $\quad$. $\quad$. $\quad$.. 203

71. Aepyceros petersi. The Angolan Pallah.. .. .. 207

72. Antidorcas euchore. The Springbuck .. $\quad$. $\quad$.. 209

Subfamily Hippotraginae

73. Hippotragus leucophaeus. The Blaauwbok .. .. 215

74. Hippotragus equinus. The Roan Antelope .. .. 217

75. Hippotragus niger. The Sable Antelope .. .. 221

76. Oryx gazella. The Gems$\begin{array}{lllll}\text { bok } & \text {.. } & \text {.. } & \text {.. } & \text {.. } 225\end{array}$

\section{Subfamily Tragelaphinae}

77. Tragelaphus scriptus $\quad$.. 230 a, subsp. sylvaticus. The Colony Bush Buck .. . . 230 b, subsp. roualeyni. Gordon Cumming's Bush-Buck 231 c, subsp. typicus. The Harnessed Antelope $\quad$. $\quad$.. 231

78. Tragelaphus angasi. The $\begin{array}{llll}\text { Inyala } & \text {. } & \text {. } & \text {.. } 234\end{array}$

79. Tragelaphus selousi. The Sitatunga $\quad$. $\quad$. $\quad$. 237
80. Strepsiceros capensis. The Kudu .. .. . . . . 241

81. Taurotragus oryx $\quad \ldots \quad \ldots 246$ a, subsp. typicus. The Eland $\quad$. $\quad . . \quad \ldots 246$ b, subsp. livingstonii. Livingstone's Elland . $\quad$. 247

Subfamily Bovinae

82. Bos caffer. The Cape Buffalo .. . . . . . 254

\section{Family GIRAfFidaE}

83. Giraffa capensis. The Southern Giraffe . . . 260

\section{Division SUINA}

Family HIPPopotaMIIDAE

84. Hippopotamus amphibius. The Hippopotamus .. . 267

Family SuIdae

85. Potamochoerus choeropotamus. The Bush Pig .. 274

86. Phacochoerus aethiopicus. The Wart-hog .. .. 278

\section{Suborder PERISSODACTYLA}

\section{Family Equidat}

87. Equus zebra. The Mountain Zebra $\quad . . \quad$.. $\quad$.. 284

88. Equus burchelli $\quad \ldots \quad \ldots 287$ a, subsp. typicus. Burchell's Zebra.. $\quad$.. $\quad$.. 288 b, subsp. antiquorum. The Damaraland Zebra .. .. 289 c, subsp. transvaalensis. The Transvaal Zebra .. 290 d, subsp. wahlbergi. Wahlberg's Zebra.. $\quad$.. .. 290 e, subsp. chapmanni. Chapman's Zebra.. $\quad$.. $\quad$.. 291 f, subsp. selousi. Selous' Zebra .. $\quad$.. $\quad$.. $\quad$.. 291 g, subsp. crawshayi, Crawshay's Zebra.. $\quad$. $\quad$.. 292 89. Equus quagga. The Quagga 294 


Family Rhinocerotidae
$\begin{aligned} & \text { PAgE } \\ & \text { 9hinoceros simus. }\end{aligned}$
$\begin{aligned} & \text { Square-lipped Rhinoceros .. } \\ & \text { 91. Rhinoceros bicornis. }\end{aligned}$
$\begin{aligned} & \text { Common Rhinoceros } \\ & \text {.. } 303\end{aligned}$

Suborder HYRACOIDEA

Family Procavildae

92. Procavia capensis. The Dassie $\quad \ldots \quad$. $\quad \ldots 310$
93. Procavia arborea. The Tree Dassie N .. $\quad$. $\quad$.. 314

94. Procavia brucii. Bruce's

Dassie. . . . . $\quad$.. 315

Suborder PROBOSCIDEA

Family Elephantidat

95. Elephas africanus. The

African Elephant .. $\quad$.. 319 


\section{NOTICE.}

The second and concluding volume of this work, which will contain a complete index, is now in the press and will shortly be issued. The second volume of the companion work on the Birds has been delayed owing to the tragic death of the author, Dr. Stark, at Ladysmith, on the 18th of November last year. The manuscript, however, has been recovered and is being prepared for the press by the Editor of the series, Mr. W. L. Sclater. 



\section{THE FAUNA OF SOUTH AFRICA. MAMMALIA.}

MammaLs may be defined as vertebrated or back-boned animals in which the blood is constantly preserved at a fixed temperature, as a rule somewhat higher than that of the surrounding air. Their young are nourished with milk provided by the mother from the mammary glands, which are situated somewhere on the lower side of the body; and the skull is provided with two condyles or swellings posteriorly, for the attachment of the back-bone. In addition to these characteristics they are (almost invariably) provided with a covering of hair; they have, as a rule, four limbs furnished with flat nails, claws or hoofs; their teeth, when present, are usually separable into three categories (i.e., incisors, canines and molars) in which case they are described as Heterodont; though in some cases, as in the porpoises, where all the teeth are constructed on one pattern, they are termed Homodont. Furthermore the teeth of the adult animal are usually preceded by another set, the milk-teeth; finally, the cavity containing the heart and lungs is completely separated from that containing the viscera by a transverse partition known as the diaphragm or midriff.

Mammals are divisible into three sub-classes of which, however, only the first is represented in the South African Fauna. These are :-

1. The Eutheria, containing by far the greater number of Mammals ; in these the young are nourished before birth by means of a placenta ; they are found all over the world.

2. The Metatheria, containing the Marsupialia, the young of which are born in a very rudimentary condition in consequence of 
the absence of a placenta, an organ by which the young are nourished while still unborn. These animals are confined to the Australian Region and to the New World.

3. The Prototheria, containing only the egg-laying Echidna and Omithorhynchus, confined to the Australian Region.

Out of the nine orders into which the Eutheria are usually divided one only (the Sirenia) is not represented in South Africa. In the following key of the other eight, the characters used are by no means the most fundamental, but such as will enable a student to recognise most easily the proper position of any animal in the series :-

A. All four limbs well developed.

a. Fore-limbs not modified for flight.

$a^{1}$. Incisor teeth always present in one jaw at least.

$a^{2}$. Hallux or pollex, or both, opposable to the other digits

PRIMATES.

Vol. I., p. 4.

$b^{2}$. Hallux and pollex not opposable.

$a^{3}$. Toes usually provided with claws sometimes with flat nails.

$a^{4}$. Incisors neither chisel-shaped nor prismatic, or if so more than two in number above and below.

$a^{5}$. Upper lip usually projecting beyond the lower; middle pair of incisors larger than the others

INSECTIVORA.

Vol. II.

$b^{5}$. Upper lip not projecting; middle incisors not larger than the others

CARNIVORA.

Vol. I., p. 24.

$b^{4}$. Incisors chisel-shaped, in the upper jaw usually, and in the lower jaw invariably two in number only

RODENTIA.

Vol. II. 
$c^{4}$. Incisors prismatic and sharppointed, two in the upper jaw and four in the lower

Hyracoidea.

Vol. I., p. 310.

$b^{3}$. Feet provided with hoofs or hoofshaped nails or not terminating in distinct toes.

UNGULATA.

(except Hyracoidea). Vol. I., p. 123.

$a^{2}$. No incisors in either upper or lower jaw

EDENTATA.

Vol. II.

b. Fore limbs modified for flight; fingers

elongated to support a membranous wing

CHIROPTERA.

Vol. II.

$B$. No posterior limbs; structure modified for aquatic life 


\section{Order PRIMATES.}

This order comprises Man, the Monkeys and the Lemurs. Although the group is a tolerably homogeneous one, the disparity in organisation of man and the highest anthropoid apes on the one hand and the lemurs on the other hand, make a definition of the order rather difficult; the following characters, however, are common to the group.

Dentition heterodont, i.e., consisting of incisors, molars and canines, and diphyodont, i.e., with both a milk and a permanent succeeding set; orbit surrounded by a bony ring more or less developed; clavicles present, radius and ulna distinct; limbs almost always with five fingers and toes terminating usually in flat nails or rarely in claws; hallux or pollex, or both opposable.

The animals contained in this order are nearly all arboreal; they are distributed all over the world, except in the northern parts of the Old and New World, and in the Australian Region.

The lemurs form a very distinct sub-order distinguished by their low organisation and generalised features, and, indeed, by many zoologists are considered to represent a separate order; they are specially characteristic of Madagascar, but have outlying forms in the Ethiopian and Oriental Regions.

\section{Key of the South African Genera.}

$A$. Inner pair of upper incisors in contact with one another; orbit completely shut off from the temporal fossa by a vertical bony plate; second digit of hind foot with a flat nail (Anthropoidea).

a. Muzzle short; tail longer than the body; ischial callosities small

Cercopithecus, p. 5.

b. Muzzle elongate and dog-like; tail shorter than the body ; ischial callosities large ..............

$B$. Inner upper incisors separated in the median Papio, p. 12.

line; orbit not shut off from the temporal fossa by a plate of bone; second digit of the hind foot with a claw (Lemuroidea)

Galago, p. 18. 


\section{Suborder ANTHROPOIDEA.}

This suborder comprises Man and all the monkeys, and is divisible into five families, namely, Hominidae (Man), Simiidae (Manlike Apes), Cercopithecidae (other Old World Monkeys), Cebidae (New World Monkeys), and Hapalidae (Marmosets); of these only the second family, to which all South African monkeys are referable, here concerns us.

The characteristic features of the suborder are briefly as follows:-Skull with orbit completely shut off from the temporal fossa by avertical plate of bone, and the lachrymal foramen situated within the limits of the orbit; pollex occasionally rudimentary or absent, second digit always well developed, and the pes almost always provided with a flattened nail; cerebral hemispheres much developed, convoluted and covering completely, or almost completely, the cerebellum; median incisors always in contact in the middle line.

\section{Family CERCOPITHECIDAE.}

The chief distinguishing features of this family are as follows :A narrow internasal septum; tail not prehensile; ischial callosities present; cheek-pouches generally present; pollex, if present, opposable; hind limbs never greatly exceeding the fore-limbs in length; crowns of the molars elongate, their tubercles forming imperfect transverse ridges.

The members of this family are confined to the Old World, and in addition to the two described below, comprise the genera. Theropithecus (the Gelada of Abyssinia), and Cercocebus (the Mangabeys, or white-eyed monkeys), which have no representatives within our limits.

\section{Genus CERCOPITHECUS.}

Type.

Cercopithecus, Erxleben, Syst. Regn. Anim. p. 22 (1777)...C. mona.

Muzzle rather short; head round; body slender with narrow loins; limbs long; tail long; anal callosities present but smaller than in the baboons and macaques; fingers and toes united by a web at the base; thumb present but short. 
Skull depressed, superciliary ridges not prominent; third lower molar with no talon, so with four cusps not five.

Dentition.-i. $\frac{2}{2}$, c. $\frac{1}{1}$, pm. $\frac{2}{2}$, m. $\frac{3}{3},=32$.

About 45 species of this genus have been described, of these 31 are recognised in the last general revision of the genus (P. L. Sclater, Proc. Zool. Soc, 1893, p. 243), while an additional 15 are noted down as not having been seen by the author. This genus is entirely confined to the Ethiopian region, ranging from Gambia and Abyssinia in the north to Cape Colony in the south; the different species being usually confined to small restricted areas.

\section{Key of the South African Species.}

A. Outside of fore and hind limbs the same colour as the body; a white frontal band separating the face and forehead; a patch of rufous hairs at the base of the tail round the callosities.

a. General colour above grizzled yellowishgrey and black

C. laiandii, p. 6.

b. General colour above grizzled greenish and black C. pygerythrus, p. 9.

$B$. Outside of fore and hind limbs black or ashy black, darker than the body; no white frontal band.

a. No red at the base of the tail ; back ashy......

b. A rufous red patch at the base of the tail; back golden yellow

C. samango, p. 9.

C. albigularis, p. 11.

\section{Cercopithecus lalandii. The Vervet.}

Simia sabaea, apud Thunberg, Mem. Acad. Petersb. iii, p. 301 (1811) [nec Linn.].

Cercopithecus faunus, A. Smith, Descr. Cat. S. Afr. Mus. p. 4 (1826) [nec Linn.].

Cercopithecus pygerythrus, Smuts, Enum. Mamm. Cap. p. 1 (1832); Grill, K. Vetens. A7ad. Handl. ii, 2, p. 12 (1858); Layard, Cat. Mamm. S. Afr. Mus. p. 14 (1861); Forbes, Handb. Primates, ii, p. 60 (1894) [nec Cuv.].

Cercocebus pygerythrus, A. Smith, S. Afr. Quart. Journ. ii, p. 22 (1834).

Cercopithecus lalandii, Is. Geoffroy, Dict. Univ. d'Hist. Nat. iii, p. 305 (1843); P. L. Selater, Proc. Zool. Soc. 1893, p. 248; id. ilid. 1893, p. 615 [fig.]. 
Literature.-Kirby (1896) p. 556, native names and habits in the Eastern Transvaal.

Vernacular Names.-Aap, Aapje or Blaauw-aap of the Dutch; Inkau of Amaxosa (Stanford), and Zulus (Kirby); Ingobiyana of Swazis, and Inkalatshana of Basutos (Kirby).

Description.-General colour above, grizzled yellowish-grey and black, each hair being annulated with sub-equal bands of these two colours; outsides of the limbs and greater part of the tail like the back, the latter a little darker; narrow band across the forehead, cheeks, chin, under-parts, and insides of fore and hind limbs white tinged with yellow; hands and feet black; skin of face black, with a few black hairs separating it from the surrounding white; hairs round the base of the tail and anus brick red; skin callosities yellowish, skin of scrotum green. Skull with a long and narrow palate as compared with C. samango.

Dimensions.-Head and body 26 ; tail without hairs 25 ; hind foot 4.75 ; from ear to nose-tip 3.75 ; skull, extreme length, $4 \cdot 0$, from condyle to premaxillae 2.75 ; breadth 2.50 ; upper cheek teeth $1 \cdot 05$.

Distribution.-The vervet is an arboreal monkey, and is therefore found only in the more wooded districts of the Colony, such as those on the southern coast and along the river beds. It is reported to occur in the Swellendam division, and thence along the southern and eastern Coasts as far as Zululand. It is also found in the thick bush along the Orange and Vaal Rivers in Prieska and Griqualand West, and perhaps extends as far north as the Transvaal; but regarding this, reliable data are not at present forthcoming. The South African Museum possesses specimens from Knysna, Pondoland and the Vaal River Valley in Griqualand West.

Habits.-Although the vervet is a very common animal in captivity, little seems recorded about its habits in the wild state; for most of the information given below I am indebted to the late Mr. W. Cloete, of Waterfall, near Bowden, in the Albany division of the Colony.

Mr. Cloete states that these animals are nearly always found in the strips of jungle fringing the banks of rivers, and never very far from water, to which they readily take, swimming with great ease and agility.

They associate together in troops composed of individuals of all ages and sexes, varying in number from small family parties to several dozens, the females carrying the very young ones. The 
adult males in the prime of life are frequently found solitary, whereas in the troops those males which have their teeth much worn down are more numerous than those whose teeth are at their best. This seems to show that the solitary individuals are those which have been unable to enter into the troops owing to the superior strength of the older males.

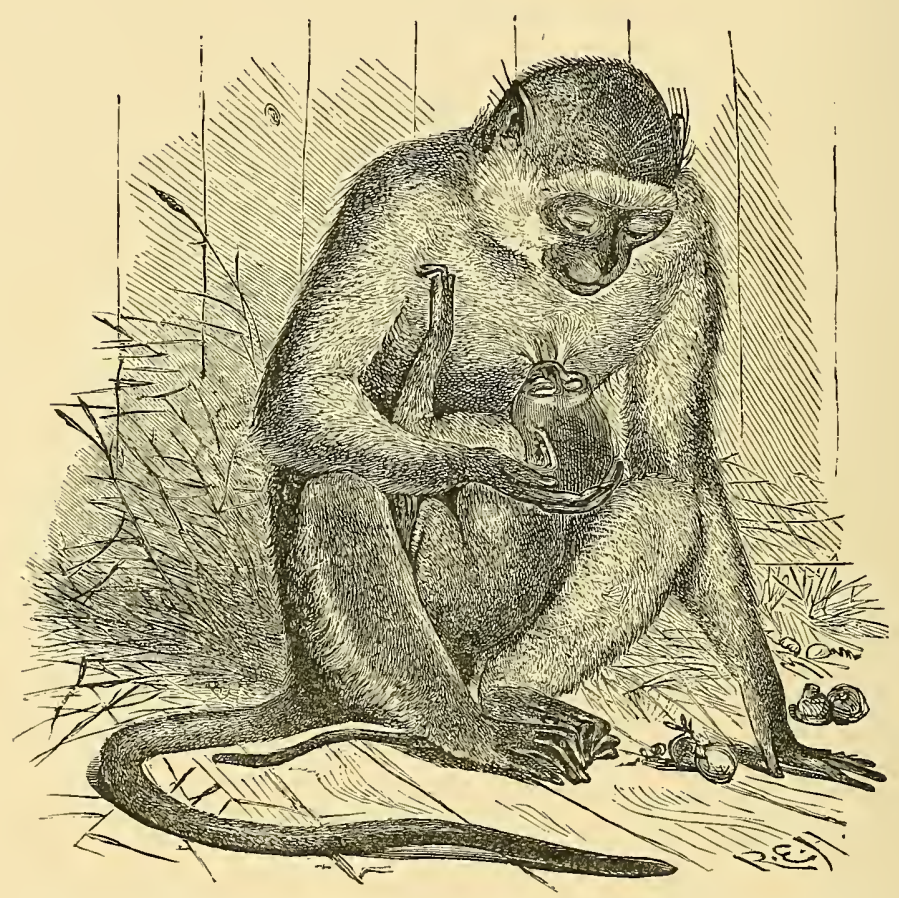

FIG. 1.-Cercopithecus lalandii, mother and young (Proc. Zool. Soc.).

The chief articles of food of this monkey are the gum and seeds of the mimosa; the fruit, and in seasons of scarcity, the pulp of the leaves of the prickly pear (Opuntia), all other fruits and vegetables, especially those of gardens, and also insects and spiders.

In captivity this animal is stated by Mr. Clocte to be more treacherous than the baboon and not so sociable and tame. It is generally to be seen in the Zoological Society's Gardens, where in 1893 a female gave birth to a young one. A curious fact observed in this connection was that the young monkey, which, however, 
only lived about two months, was in the habit of sucking both its mother's teats at once, as is shown in the sketch (fig. 1). The period of gestation does not appear to have been recorded, but that of an allied form the malbrouck (C. cynosurus) is stated by Babu R. B. Sanyal of the Calcutta Zoological Gardens, to be seven months.

\section{Cercopithecus pygerythrus. The Mozambique Monkey.}

Simia pygerythra, F. Cuvier, Hist. Nat. Mamm., livr. xxiv (1821).

Cercopithecus pygerythrus, Desmarest, Mamm. Suppl. p. 534 (1822); Peters, Reise Mozamb. Saügeth. p. 4 (1852); P. L. Sclater, Proc. Zool. Soc. 1893, p. 249; id. List Vert. Zool. Gardens, 9th ed., p. 11 (1896) [Beira district].

Description.-This monkey, which apparently takes the place of Cercopithecus lalandii in East Africa, seems only to differ from it in its much more greenish coloration, the annulations being alternately of black and green instead of black and grey; the fur is also said to be longer and softer in this species than in C. lalandii.

Had it not been for the fact that M. Milne Edwards of the Museum of Natural History in Paris, has examined the types of both Cuvier (C. pygerythrus), and of Geoffroy (C. lalandii), and has most kindly communicated the results of his examination to me to the effect that the two species are quite distinct, I should have been inclined to have identified them with one another.

Distribution.-An example of this monkey from Beira was presented to the Zoological Society of London by Mr. H. P. Hast in 1894, this is the only record of its occurrence within our limits; it appears to be found northwards along the East coast as far as Mombasa, and inland as far as Kilima-njaro, and has been recorded by Peters from Sena and Tette on the Zambesi.

A flat skin from the neighbourhood of Salisbury recently presented to the South African Museum by Mr. Marshall, seems referable to this species, so that this form probably replaces $C$. lalandii in Rhodesia.

\section{Cercopithecus samango. The Samango Monkey.}

Cercopithecus samango, Sundevall, Ofvers. K. Vet. Alad. Forh. Stockholm, i, p. 160 (1845); Peters, Reise Mozambique Saïgeth. p. 4 (1852) [Inhambane]; id. Proc. Zool. Soc. 1865, p. 400 [Angola] ; P. L. Sclater, Proc. Zool. Soc. 1893, p. 251.

Vernacular Name.-Insimango of Amaxosa (Stanford).

Description.-Above dark, grizzled, each hair ringed black and yellow, the black rings being the longest; darkest on the head and 
gradually lightening towards the tail. Below chin, throat, belly, lower side of proximal part of tail and inside of hind legs dirty white; fore limbs and hands black, outside of hind limbs greyish black, feet black, no rufous patch at the sides of the anus, tail gradually darkening, the distal two thirds being quite black. Skin of face, inside of ears, of feet, anal callosities and nails black.

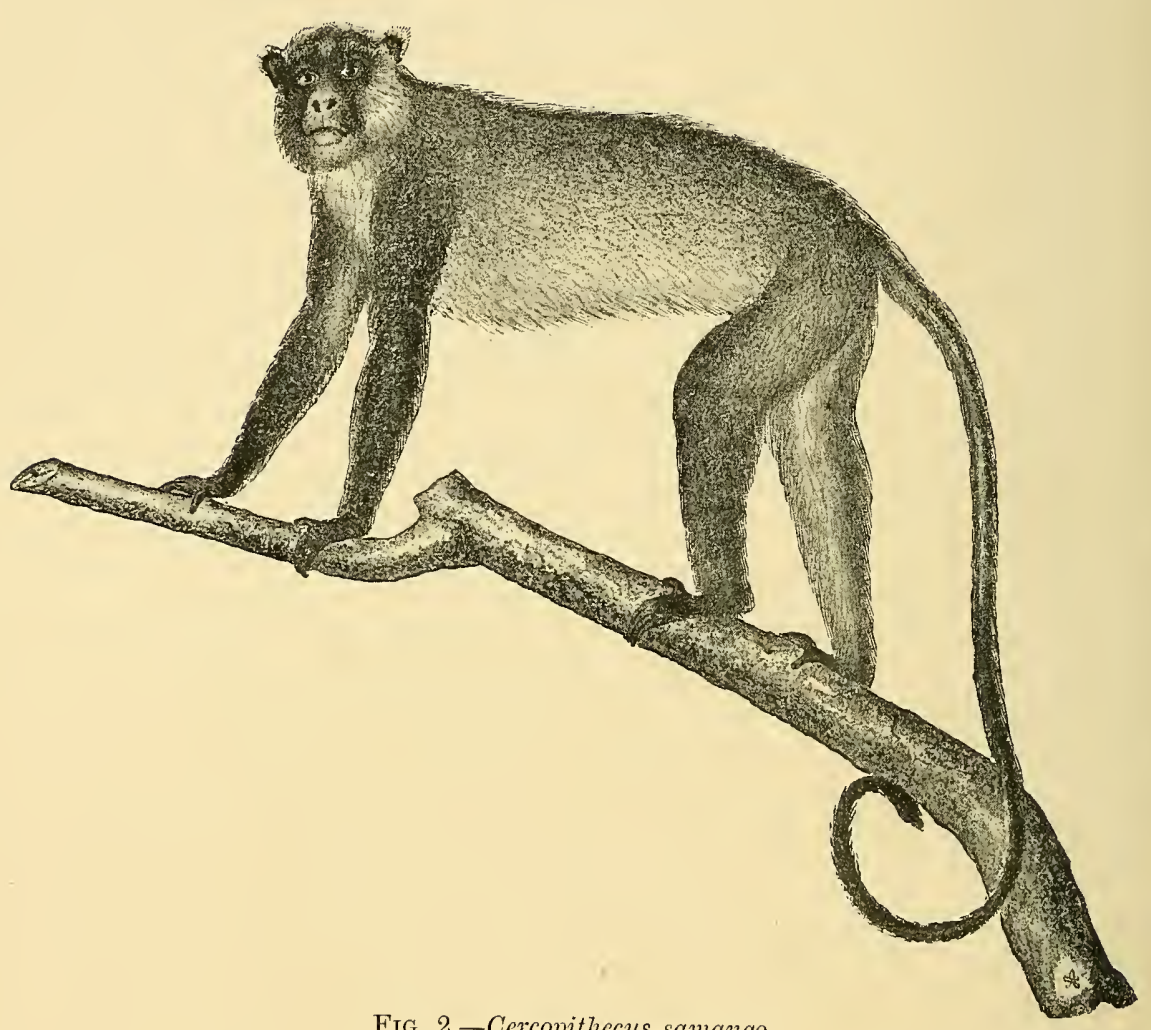

FIG, 2.-Cercopithecus samango.

Dimensions.-Of a mounted specimen; head and body, 27.0; tail without hair 31.0 ; length of hind foot 5.0 ; from ear to nose-tip $4 \cdot 0$; skull extreme length $4 \cdot 30$; condyle to premaxillae $3 \cdot 30$; breadth 2.90 ; cheek teeth $1 \cdot 0$.

Distribution.-This monkey is found in the eastern parts of the Colony such as the King Williamstown district, whence it ranges 
on up the East Coast through Natal (where it is rare) and Zululand to Inhambane; it is further stated by Dr. Peters to reappear in Angola.

The South African Museum possesses examples obtained in the neighbourhood of Port St. John, in Pondoland; and there are several from the Pirie bush in the King Williamstown Museum.

Habits.-Very little is recorded about this monkey; Mr. Sidney Turner, of Port St. Johns, informs me that it is found only in the thickest forest, usually in dark damp places and gorges into which the sun seldom or only for a short time penetrates, and that it never associates with the vervet.

The skins were highly prized and much sought after by the Zulus, as they formed part of the distinguishing dress of one of the regiments of that nation before their military power was broken.

\section{Cercopithecus albigularis. Sykes' Monkey.}

Semnopithecus albigularis, Sykes, Proc. Zool. Soc. 1831, p. 106.

Cercopithecus albigularis, Sykes, Proc. Zool. Soc. 1832, p. 18; P. L. Sclater, Proc. Zool. Soc. 1893, p. 251 ; Forbes, Handb. Primates, ii, p. 67 (1894).

Cereopithecus erythrarchus, Peters, Reise Mozambique Saïgeth. p. 1, pl. i. (1852).

Description.-Fur long, thick and abundant, general colour dark olive on the head and shoulders, darkest on the head; no frontal band of white; cheeks paler than the head; from the middle of the back to the root of the tail a very rich golden yellow, the hair annulated with that colour and black; chin and upper chest white, sides and belly grey-grizzled not white; a pure rufous patch below the tail on either side of the anus; fore limbs coal black, hind limbs ashy black being quite black at the toes; tail with basal three inches golden like the back, then darker, the last three quarters being coal black.

Dimensions.-From a flat skin; head and body 25; tail 24; of the type 23 and 26 respectively.

Distribution.--This species was originally described by Colonel Sykes from a living specimen of which the exact habitat was unknown; it has since been recorded from various parts of East Africa from Kilima-njaro to Mozambique and Nyasaland. A flat 
skin from which the description was drawn up, and which is doubtless referable to this species, was obtained near Umtali in Mashonaland and presented to the South African Museum by Mrs. Morrison. This is the only record of its occurrence in South Africa.

The following species of the genus though not yet ascertained to inhabit South Africa will probably be eventually found within our limits.

Cercopithecus stairsi, P. L. Sclater, Proc. Zool. Soc. 1892, p. 580, pl. xl ; 1893, pp. 252 and 612.

This species can be at once distinguished by the bright red patches in front of the ears. The original specimen was obtained alive in the Zambesi delta and presented to the Zoological Society of London by Dr. J. A. Moloney. Since then two other live examples from Mozambique and British East Africa have been acquired by the same Society.

\section{Genus PAPIO.}

Type.
Papio, Erxleben, Syst. Reg. Anim. p. 15, (1777) .......... P. sphinx.

Muzzle much elongated and swollen by the enlargement of the maxillae, with nostrils at the tip; ischial callosities large; tail short; the fore and hind limbs are of approximately equal length and are much more adapted for terrestrial quadrupedal progression than those of the other monkeys. Skull (fig. 3) with the facial portion much elongated and a conspicuous ridge along the maxillae on either side, so that the upper surface of the face between the orbits and the nasal opening is flattened.

Dentition.-i. $\frac{2}{2}$, c. $\frac{1}{1}, \mathrm{pm} . \frac{2}{2}, \mathrm{~m} . \frac{3}{3}=32$. Teeth large and strong, the canines much elongated and very sharp.

About twelve recent species of this genus have been described, all of them confined to the Ethiopian region.

Key of the South African Species.

A. Hair of back brown, obscurely ringed; skin of face ashy black.............................

$B$. Hair of back ringed yellow and black; skin of face flesh-coloured

P. porcarius, p. 13.

P. cynoceplialus, p. 16. 


\section{Papio porcarius. The Chacha or Baboon.}

Simia porcaria, Boddaert, Naturf. xxi, p. 17, pl. i. (1787); Grill, $K$. Vetens. Akad. Handl. ii, 2, p. 12 (1858).

Simia sphinx, Thunberg, Mem. Acad. Petersb. iii, p. 301 (1811).

Papio porcarius, Geoffroy, Ann. Museum, xix, p. 202 (1812) ; Smuts, Enum. Mamm. Cap. p. 2 (1832) ; Forbes, Handb. of Primates, i, p. 263 (1894).

Cynocephalus ursinus, A. Smith, Descrip. Cat. S. Afr. Mus. p. 1 (1826). Cynocephalus porcarius, A. Smith, S. Afr. Quart. Journ. ii, p. 25 (1834); Layard, Cat. Mamm. S. Afr. Mus. p. 15 (1861); Distant, Zoologist (4) i, p. 29 ; Schönland, ibid. p. 155 (1897) [habits].

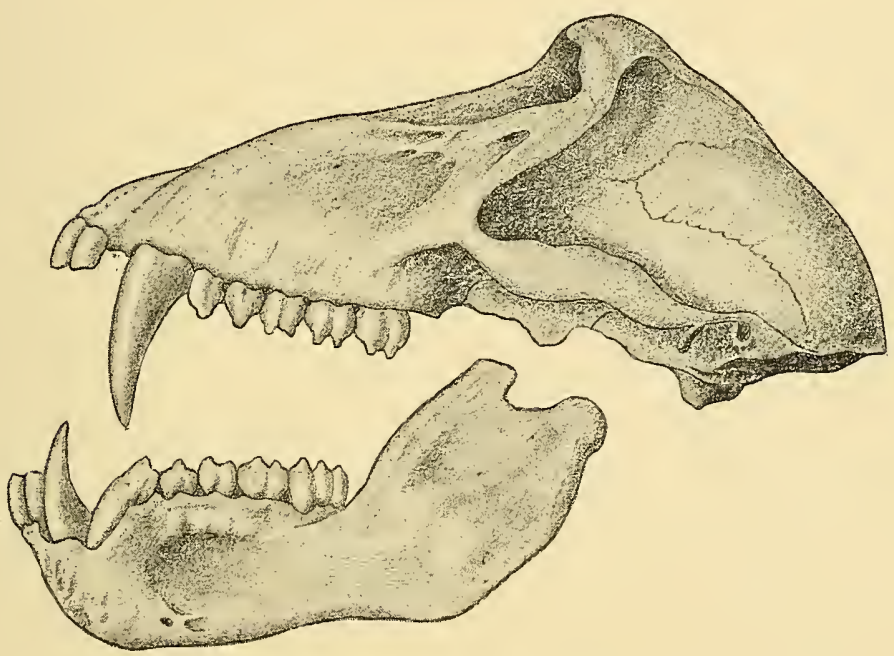

FIG. 3.-Side view of the skull of Papio porcarius.

Literature.-Tachard (1685), p. 90, note of occurrence on Table Mountain; Kolben (1731), ii, p. 120, deseription and quaint account of habits; Sparrman (1785), ii, p. 243, account of meeting with on the Fish River; Hall (1859), p. 377, and (1860) p. 112, notes on habits; Holub (1882), p. 245, account of habits and shooting; Martin (1890), p. 238, note on habits ; Moseley (1892), p. 123, observations near Simonstown; Kirby (1896), p. 557, native names and habits in the Eastern Transvaal; Kirby (1899), p. 319, occurrence in the Beira District.

Vernacular Names.-Bavian of the Dutch Colonists; T'chatikamma of the Hottentots, whence is derived the name Chacma often used in Europe; 
Infene of Amaxosa (Stanford); Imfena of Swazis and Zulus; Tshweni of Basutos (Kirby).

Description.-General colour dark brown with a tinge of yellow which is more conspicuous on the forehead; the hairs dark brown at the base and tip with, in most cases, a subterminal band of yellow; hair on the nape of the neck and the hinder part of the cheeks elongated forming a slight covering to the ears; the lower part of the arms and legs darker than the rest of the body, almost black, hair on the upper parts of the hands and feet quite black; naked skin of the face and chin brownish black, the upper eyelids being flesh-coloured; ears nearly naked; nails black; the callosities dark sienna red in the old males; tail about half the length of the head and body, carried with the proximal third directed somewhat upwards, and the distal two-thirds downwards.

Skull of the old male with very heavy prominent ridges on the frontals above the eyes and also running along the maxillary bones from the orbits to the nasal openings.

Upper canines very strongly developed measuring in the case of one old male in the Museum 1.75 in. in the socket, and with a very sharp edge posteriorly.

Female similar, but with less developed mane and muzzle; callosities flesh-coloured.

Dimensions.-From an old mounted male; head and body $3 \mathrm{ft}$. 4 ; tail without hair 18 ; with 20 ; length of hind foot 8.0 ; from ear opening to nose-tip 8.5 ; skull, extreme length 8.5 ; length from premaxillae to condyle 6.0 ; breadth 4.35 ; upper cheek teeth 2.12 .

Distribution. - The baboon or bavian is found all over South Africa, and is abundant in almost all the divisions of Cape Colony, Natal, and the Transvaal. It appears to extend up into Rhodesia, as it is recorded by Kirby from the country between Beira and the Zambesi, but does not seem to cross that river; baboons are still plentiful in the southern part of the Cape Peninsula and are sometimes seen on Table Mountain itself. There are in the South African Museum skins and skulls from the Stellenbosch, Tulbagh, Worcester, Beaufort West and Albany divisions of the Colony.

History. -The baboon has long been known in South Africa, and is frequently mentioned in van Riebeck's diary; all the early travellers, Tachard, Kolben, Sparrman, and le Vaillant, give a more or less full account of its occurrence and habits. Among more modern authors little has been written on the subject and in the 
following account I have chiefly relied on some notes sent to me by Mr. W. Cloete, of Waterfall, near Grahamstown.

Habits.-The chacma is an inhabitant of the steep and rocky krantzes which abound in all parts of Africa, and although most frequently found in treeless country, is a very good tree climber when opportunity offers; in some parts of its range where krantzes are few it even sleeps in tall trees. They associate in troops of varying numbers up to about one hundred individuals; when moving from place to place the old males are usually seen on the outskirts and always form a rear guard; also when resting a sentinel or two is always placed on the top of a rock, in order to warn the troop of approaching danger.

They rest at night in crevices of the krantzes, coming out during the day only. They are frequently captured by surrounding their lairs before daylight, when all are asleep. The chief enemy of the baboon apart from man is the leopard, which, however, seems to confine his attention to females and young ones, as an adult old male would probably be a good match even for a leopard.

The pace of baboons is not very rapid; on level ground they can easily be overhauled by ordinary dogs, but in rough country and on hill sides they can hold their own with great ease. They move with the first part of the tail somewhat up-curved, and the last two-thirds hanging straight down.

The cry of this animal is a deep hoarse bark, and is compared by Professor Moseley, who observed their habits in the neighbourhood of Simons Town, to a German " hoch" much prolonged.

The baboon may almost be described as omnivorous; the fruit and leaves of the prickly pear, the more thorny ones being preferred, wild fruits, berries, and bulbs, and the white sweetish pith at the lower ends of the aloes form the greater part of its diet. Insects, scorpions, centipedes and even lizards are eagerly sought after by turning over loose stones, and Mr. Distant relates how when first searching for insects in the Transvaal he was intensely surprised to find stones turned over before his arrival, as if some other "geodephagous coleopterist had anticipated him;" this he afterwards found was due to the insect-searching attributes of the baboons.

Mr. Cloete informs me that wild honey is also a favourite article of diet; he has himself observed a male chacma robbing a bee's nest in a hole in the ground; the method pursued by the animal was to rush at the nest, seize a comb, and after dropping it a 
few times and rolling it about to get the bees off, to carry it away a short distance so as to be able to devour it out of the way of the infuriated bees.

The baboons cause great annoyance to the farmers; they frequently devastate orchards and fruit gardens, they suck and devour ostrich eggs, and of late years they have taken to killing and disembowelling lambs and kids for the sake of the curdled milk in their stomachs.

The chacma is frequently seen in captivity, and examples of it are nearly always to be found in the Zoological Gardens in London. When young it is a delightful pet, full of intelligence and affection, especially towards its master, though sometimes averse to strangers; with increasing age, however, it becomes morose and dangerous. Baboons are frequently hunted by farmers with dogs and guns, the most ordinary procedure being to surround the "kopje" where they are known to be sleeping before daylight; they defend themselves from the attacks of dogs with considerable vigour, often inflicting very severe wounds with their long eye teeth, which sometimes in the case of old males reach a length of two inches.

\section{Papio cynocephalus. The Yellow Baboon.}

Papio cynocephalus, Geoffroy, Ann. Mus. xix, p. 102 (1812) ; Lorentz, Ann. kk. Hofmus. ix, notiz. p. 67 (1894).

Cynocephalus babouin, Desmarest, Mamm.p. 68 (1820); Peters, Reise Mozambique Saügeth. p. 4 (1852); P. L. Sclater, List Vert. Zool. Gardens, 9th ed., p. 33 (1896) [Mashonaland].

Papio babuin, Forbes, Handbook of Primates i, p. 265 (1894).

Literature.-Kirby (1899), p. 320, occurrence north of Beira.

Description.-General colour of fur brownish yellow; ears naked, flesh-coloured like the face; upper side of body uniform brownish yellow, the hairs with broader yellow and narrower black rings, sides darker, below lighter than the back; hands and feet black; whisker tufts pale saffron yellow. (Forbes).

Dimensions.- Smaller than the chacma; Kirby gives the total length of a male $3 \mathrm{ft} .4$; of a female $3 \mathrm{ft} .1$.

Distribution. - The yellow baboon is found throughout the greater part of Africa, extending from Abyssinia and Nubia in the north, to the Coanza River in Angola in the west and the Zambesi River in the south. 
An example rom Mashonaland has recently reached the Zoological Gardens in London, so that it must be included in the South African Fauna as defined in this work.

Habits.-In this respect the yellow baboon seems to resemble the chacma. Sir Harry Johnston in his British Central Africa, p. 287, says of it that it is very common everywhere in Nyasaland, and very bold and cunning. It is constantly robbing the natives'

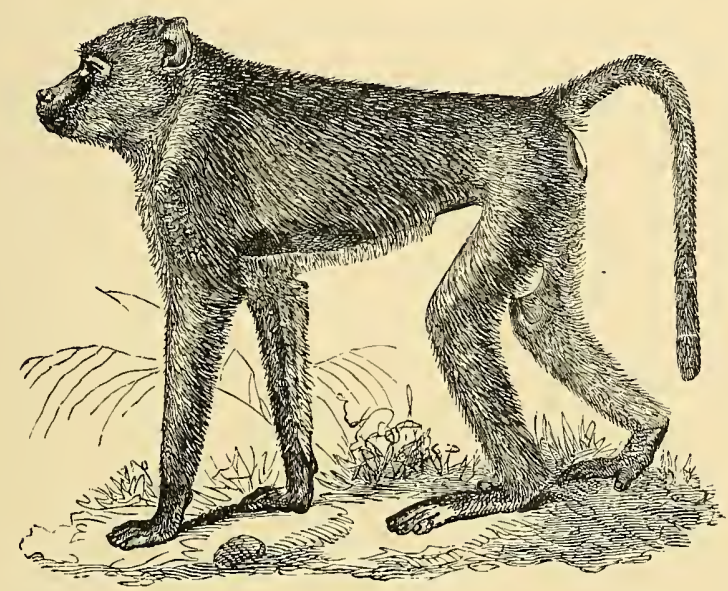

Fig. 4.-The Yellow Baboon (Papio cynocephalus). (Flower and Lydekker).

plantations, and the women profess to go in terror of the large males, as they say that the latter will attempt to outrage them if they see no man accompanying the party; this is also related of the chacma of South Africa. When the baboons descend to raid plantations, one or more of their number invariably stand sentry to warn the rest of the troop of approaching danger.

\section{Suborder LEMUROIDEA.}

This suborder contains the animals known generally as lemurs, all of which are small or of moderate size and arboreal, and generally nocturnal in their habits.

The chief anatomical characters separating them from the true 
monkeys are as follows:- Skull with the orbit freely communicating with the temporal fossa below the post-orbital bar, and with the lachrymal foramen opening outside the orbit; pollex and hallux well developed, the second or index digit of the manus sometimes rudimentary, that of the pes always with a claw; cerebral hemispheres not completely overlapping the cerebellum; median incisors usually separated by a gap in the middle line.

The head quarters of the lemurs are undoubtedly in the large island of Madagascar to which by far the greater proportion of the species is restricted. They extend, however, in smaller numbers across Africa as far as Senegambia and through Southern Asia into the Philippines.

Only one of the three families here concerns us, as the other two, the Chiromyidae, containing only the aye-aye, and the Tarsiidae, containing the tarsier, are confined to Madagascar and the Malayan regions respectively.

\section{Family LEMURIDAE.}

The characters of the family may be considered with those of the only genus represented in South Africa. Some six additional genera are confined to Madagascar, two to Africa proper and two to the Oriental region.

\section{Genus GALĀGO.}

Galago, Geoffroy, Mag. Encycl. Ann. ii, i, p. 49

Type.

(1796) ............................................... senegalensis. Otolicnus, Illiger, Prodr. Mamm. p. 74 (1811) .....G. senegalensis. Otogale, J. E. Gray, Proc. Zool. Soc. 1863, p. 139...G. garnetti.

Ears large, round and membranous, naked, capable of being folded at the will of the animal; eyes large and approximated; fingers and toes long and slender; tail thick and bushy.

The skull (fig. 5) is high and broad with a rounded brain case and short facial region; the angle of the lower jaw is produced backwards.

Dentition.-i. $\frac{2}{2}$, c. $\frac{1}{1}, \mathrm{pm} . \frac{3}{3}, \mathrm{~m} . \frac{3}{3}=36$. The last upper premolar has two large external cusps, and nearly equals the first 
molar in size, the upper incisors are small and separated in the middle line, the lower incisors and canines are all parallel and procumbent, the anterior premolar appearing at first sight to be the canine.

This genus, which consists of about twelve species, is confined to the tropical and sub-tropical portions of Africa.

In addition to the two species mentioned below, a third, Galago crassicaudatus, of larger size and darker rufous colour than G. garnetti, has been stated to occur in Natal, though I have been unable to find on what authority; as, however, it is undoubtedly found just north of the Zambesi it may, eventually, have to be included in our fauna. Galago monteiri of Angola also occurs just beyond our frontier.

\section{Key of the South African Species.}

$A$. Larger ; tail of equal bushiness throughout; snout produced

G. gametti, p. 19.

$B$. Smaller; tail more bushy towards the tip; snout very short

G. moholi, p. 20.

\section{Galago garnetti. Garnett's Lemur.}

Otolicnus garnettii, Ogilby, Proc. Zool. Soc. 1838, p. 6.

Otogale garnetti, J. E. Gray, Proc. Zool. Soc. 1863, p. 140, [fig. skull]. Galago garnettii, Mivart, Proc. Zool. Soc. 1864, p. 646 ; P. L. Sclater, Proc. Zool. Soc. 1864, p. 711, pl. xl; id. ibid. 1872, p. 689; Forbes, Handb. Primates i, p. 40 (1894); Pousargues, N. Arch. Mus. (3) vi, p. 138 (1894).

Description.-General colour yellowish grey, the hair soft and thick and the bases slaty, while a number of longer hairs with black shining tips are scattered all over the body especially on the back; hairs on the muzzle shorter; a faintly marked white stripe from between the eyes to the nose; chin and lower sides yellowish white; ears nearly naked and black; limbs of the same colour as the back; hands and feet darker, nearly black; tail long and bushy of same colour as the back but the bases of hairs not slaty, fingers and toes all provided with a flat nail, except the second of the hind limb which has a claw. 
Skull with the facial portion considerably elongated so that the nasals are as long as the diameter of the bony orbits.

Dimensions.-From a skin; head and body 14; tail with terminal hairs 11 ; hind foot 3.5 ; from ear opening to nose tip 2.20 ; ear about $1 \cdot 80$; skull length $2 \cdot 30$, breadth $1 \cdot 45$, cheek teeth $0 \cdot 70$.

Distribution.-Garnett's lemur is found in Natal and Zululand; and should it on further investigation be found to be identical with $G$. agisymbanus, as has been suggested by some authors, its range will be extended northwards as far as British East Africa.

The South African Museum possesses a specimen from Natal.

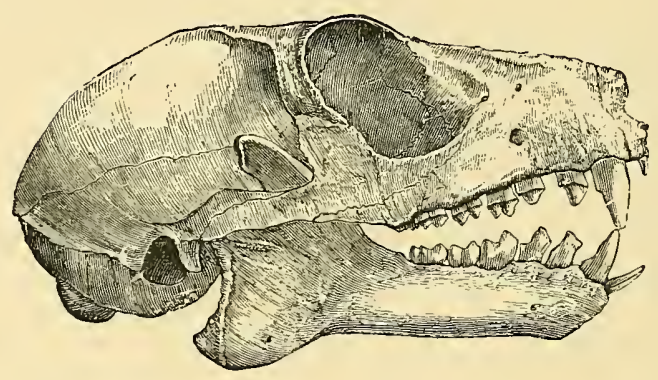

Fig. 5.-Skull of Galago garnetti (Proc. Zool. Soc.).

Habits.-Very little seems to be known about this lemur although it was described so long ago as 1837 by Mr. Ogilby. In captivity it is stated to exhibit no fear of cats and dogs and to be very sprightly and tricky; it kills all it can pounce upon and overpower; on the ground it jumps upright like a kangaroo on its hind limbs without using its forefeet, covering several feet at a spring. It is nocturnal in its habits and feeds on fruits and perhaps insects.

\section{Galago moholi. The Moholi Lemur.}

Galago moholi, A. Snith, App. Report Exped. Explor. South Africa, p. 42 (1836); id. Illustr. Zool. S. Afr. Mamm. pl. viii (1839); Layard, Cat. Mamm. S. Afr. Mus. p. 17 (1861); Gray, Proc. Zool. Soc. 1863 p. 146 [fig. skull] ; Distant, Zoologist (4) i, p. 83 (1897). Otolicnus senegalensis, apud Peters, Reise Mozamb. Saïgeth. p. 11, pl. iv, figs. 10, 11 [skull] (1852). 
Galago senegalensis, Forbes, Handb. Primates i. p. 41 (1894);

Pousargues, N. Arch. Mus. (3) vi, p. 144 (1894) [in part].

Literature.-Chapman (1868), p. 13, note on habits; Kirby (1896) p. 556, native names and habits in Eastern Transvaal.

Vernacurar Names. - Nacht aapje of the Dutch, Night-ape or Bush baby of the English Colonists ; Ngwanangwaila of the Basutos (Kirby).

Description.-General colour greyish brown, the basal part of the fur dark slaty and the tips yellowish grey, the fur being very fine and soft ; the face somewhat paler than the back with a distinct white stripe along the nose separating two black rings round the eyes; the chin and throat are white, the rest of the underparts washed with yellow in the male, paler in the female; outside of the limbs of the same colour as the back, hair on feet pale; tail long covered with long sparse brown hairs, of the same colour throughout, getting more bushy towards the tip.

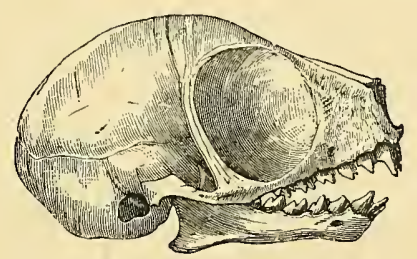

FIG. 6. -Skull of Galago moholi (Proc. Zool. Soc.).

Head rounded, snout short and pointed, ears pale, naked inside, covered with a few fine yellow hairs outside; eyes deep topaz yellow; fingers and toes with flat nails except the second toe which has an upstanding thin claw.

Skull with smooth and rounded brain case, large orbits completely encircled, but not entirely closed in by bone, and with a short slender facial portion, the length of the nasal bones being about half the diameter of the orbit.

The upper incisors are very small, close to the canines, and separated by a gap in the middle line; the canines short, about twice the length of the following tooth; the anterior and median premolars are like the canines but with traces of the anterior and posterior cusp; the posterior premolar is like the succeeding molars with four chief cusps connected by an oblique ridge from the anterior inner to the posterior outer cusp. In the lower jaw the four incisors 


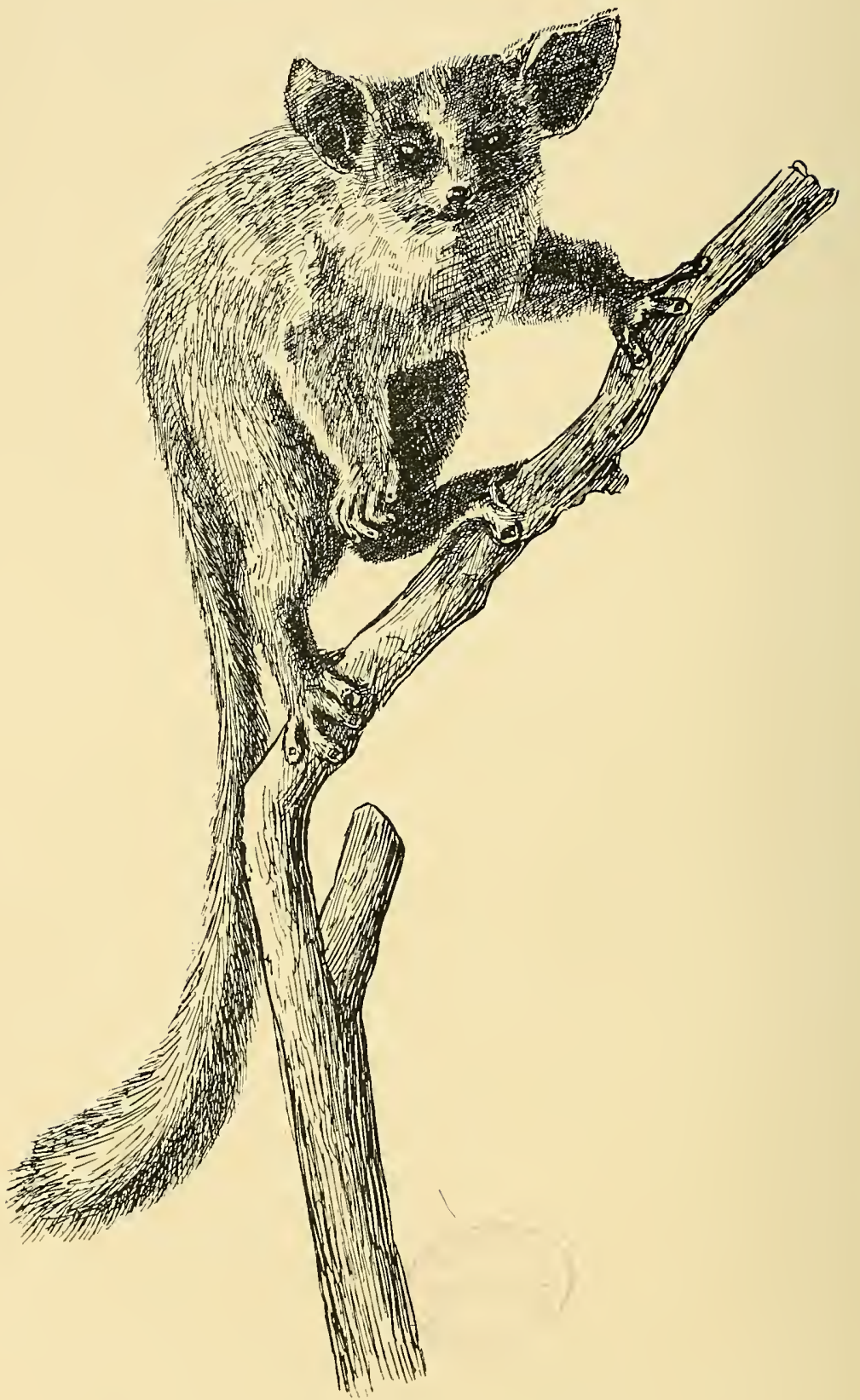

FIG. 7. - The Moholi Lemur (Galago moholi.) 
are long and procumbent, the succeeding canines resemble the incisors but are slightly stouter; the anterior and median premolars are procumbent and tusk-like, exceeding the canine in every way, the posterior premolar resembles the molars.

Distribution.-The moholi lemur was met with by Sir A. Smith, who was its first discoverer, on the Limpopo River in about $25^{\circ} \mathrm{S}$. Lat., i.e., in the Rustenburg district of the Transvaal ; from here it extends all over the wooded districts of the Transvaal and Rhodesia to Nyasaland, where it has been recorded by Thomas. It also occurs in Mozambique and Angola but does not appear to reach the Colony or Natal.

The South African Museum possesses specimens from the Transvaal and from the neighbourhood of Lake Ngami.

This little lemur is closely allied to the West African form with which it has frequently been confounded, but an examination of the types of the two species ( $G$. senegalensis in Paris and G. moholi in London) shows that they are really distinct.

Dimensions.-From a mounted specimen; head and body 7 ; tail with hair 8 ; hind foot 2.5 ; from ear opening to nose-tip 1.4 ; skull extreme length 1.5 ; zygomatic breadth 1.0 ; upper cheek teeth $0 \cdot 4$.

Habits.-The moholi lemur is a purely arboreal animal, and is therefore only found in wooded districts; it is also nocturnal spending the day in a nest or lying on the branch of a tree. It is found singly or in pairs, and is exceedingly active, springing great distances from branch to branch; in captivity too the facility with which it bounds or almost flies across the room has frequently been remarked. Its food consists of pulpy fruits and insects.

The female is said to bear two young ones at a birth though a pair kept in captivity by Mr. Distant only produced one.

Sir A. Smith remarks that in their manners these lemurs manifest considerable resemblance to monkeys, particularly in their propensity to the practice of ridiculous grimaces and gesticulations. 


\section{Order CARNIVORA.}

This order contains a large assemblage of highly organised and powerful animals chiefly flesh-eating in diet, such as the cats, dogs, weasels and seals. They are distinguished by possessing five or sometimes four toes usually armed with claws, by the pollex and hallux not being opposable and by their teeth, of which there are two sets, each divided into incisors, canines, and molars, all of which are rooted.

Other characters are; incisors small and pointed, usually three in number on either side, of which the median pair are the smallest, canines strong, conical and well developed, molars usually compressed, sharp edged and adapted for cutting; condyle of the lower jaw on a level with the molars and working in a transverse semicircular groove, the glenoid cavity, restricting all lateral motion; clavicles rudimentary or absent, radius and ulna distinct, no centrale; cerebral hemispheres always convoluted to a certain extent; stomach simple; caecum small or absent ; uterus bicornuate, placenta discoidal and generally zonary; mammae abdominal and of varying number.

The order is divided into two suborders (by some zoologists considered as separate orders) for the terrestrial and marine forms respectively, and comprises altogether eleven families, representatives of seven of which are found in South Africa, while the other four, namely the bears (Ursidae), racoons (Procyonidae), walruses (Trichechidae) and true seals (Phocidae) are entirely absent.

The following synopsis gives the characters by which the South African suborders and families can be separated. These characters unfortunately are not always very obvious, and the skull (fig. 8) must be referred to for further explanation. Keys to the genera where necessary will be found under the families. 


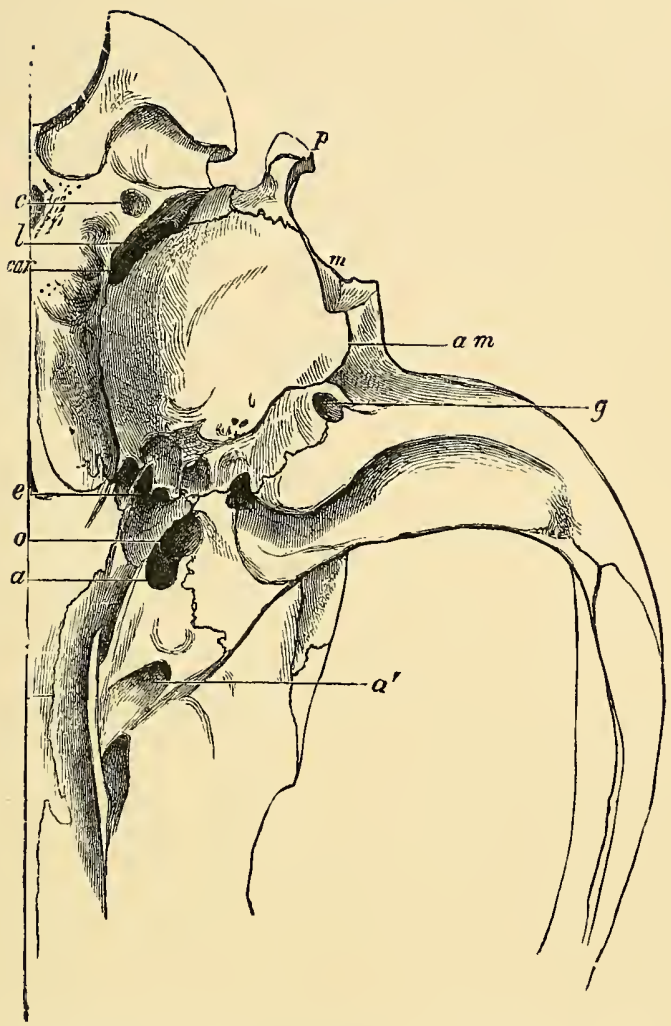

Fig. 8. - The right half of the hinder part of the base of the cranium of the wolf (Canis lupus) to show:-c, condyloid foramen; $l$, foramen lacerum posterius ; car, carotid canal ; $e$, eustachian canal ; $o$, foramen ovale ; $a$, the posterior, and $a^{\prime}$, the anterior opening of the alisphenoid canal ; $P$, the paroccipital process ; $m$, the mastoid process ; $a m$, the external auditory meatus ; $g$, the glenoid foramen below which is the glenoid cavity for the condyle of the mandible (after Flower).

A. Limbs adapted for terrestrial life, not forming flippers (Suborder Fissipedia).

a. Auditory bulla inflated and divided into two chambers by a transverse partition.

$a^{1}$. Head short, digitigrade, toes $5-4$ with sharp, curved and generally retractile claws ............

$b^{1}$. Head elongate, toes generally $5 \cdot 5$, claws variable

Felidae, p. 27.

$c^{1}$. Head elongate, toes 5-4, claws blunt, molars almost rudimentary

Viverridae, p. 49.

Protelidae, p. 79. 
b. Auditory bulla inflated but not divided.

$a^{1}$. Condyloid and glenoid foramina concealed or

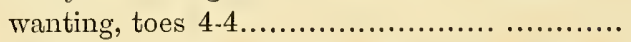

$b^{1}$. Condyloid and glenoid foramina present, toes

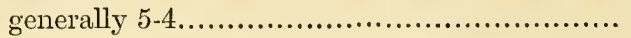

c. Auditory bulla not inflated or divided, toes 5-5 ... Hyaenidae, p. 82. Canidae, p. 91. Mustelidae, p. 106. $B$. Limbs adapted for aquatic life forming flippers and enclosed in a common integument (Suborder Pinnipedia).

Otariidae, p. 118.

\section{Suborder FISSIPEDIA.}

In this suborder are included all the Carnivora the limbs of which are generally adapted to progression on land, although some members of the suborder, such as the otter, may be partially aquatic in their habits.

The toes are always provided with claws, which are strong and generally sharp and curved, and neither the first digit of the fore limb nor the first or fifth of the hind limb ever surpass the others in length; with rare exceptions there are three pairs of incisors above and below; the molars are never uniform, but there is always a pair of so-called carnassial teeth, the upper one of which is the last premolar and the lower one the anterior molar, these form a pair of blades acting on one another like a pair of scissors.

The classification of the Fissipedia presents a good many difficulties. Mr. Turner and Professor Flower divide the suborder into three sections named AFluroidea, Cynoidea, and Arctoidea, from the Greek words for cat, dog and bear, each of which forms a type of the respective divisions.

The characters by which these sections are separated are chiefly certain modifications of the bulla or bony chamber of the ear and of the alisphenoid canal, a passage below a little bridge of bone through which the external carotid artery passes at the base of the skull. (See fig. 8, p. 25.)

\section{Division ALUROIDEA.}

Auditory bulla dilated, rounded, smooth, thinwalled and (except in the Hyaenas) divided into two chambers ; auditory meatus short; paroccipital process applied to and spread over the bulla: 
mastoid process not much developed; carotid canal small and inconspicuous ; condyloid and glenoid foramina concealed or wanting ; caecum small.

Representatives of all the four families which belong to this division are found in South Africa.

\section{Family FELIDAE.}

The characters of the genus Felis given below adequately diagnose the family, except for the fact that the toes are not always completely retractile and that the inner tubercle of the upper carnassial does not always bear a cusp.

The only two genera may be distinguished as follows :-

$A$. Claws completely retractile, upper carnassial with

a strong inner cusp and root

Felis, p. 27.

$B$. Claws not completely retractile, upper carnassial

with an inner root but no cusp

Cynaelurus, p. 46.

\section{Genus FELIS.}

Felis, Linnaeus, Syst. Nat., 12th ed. i, p. 60 (1766) ........ $\quad$ F. Feo.

This genus contains the true cats, the most highly organised of all the animals composing the order Carnivora.

The cats are digitigrade (i.e., walk on the tips of the toes), and the fore limbs are provided with five, the hind limbs with four toes. The claws borne by these toes are large, strongly curved, compressed, very sharp, and completely retractile, that is to say, the last phalangeal bone which bears the claw, can be folded back into a special sheath provided for its reception on the outer side in the fore foot, on the upper side in the hind foot, of the middle phalangeal bone.

The skull is short and rounded, and the auditory bullae are large, smooth, and inflated.

The dentition is as follows:-i. $\frac{3}{3}$, c. $\frac{1}{1}, \mathrm{pm} . \frac{3 \text { or } 2}{2}, \mathrm{~m} . \frac{1}{1}=28$ or 30 ; the most remarkable tooth is the last premolar of the upper jaw, which with the solitary molar of the lower jaw form a pair 
of sharp cutting blades acting like scissors and termed the carnassials, this feature attains its most complete development in this genus. It is further to be noted that the upper carnassial bears on its inner side a tubercle with a cusp; the solitary upper true molar is small and placed somewhat transversely to the other teeth ; the canines are very large and strong, the incisors small.

This genus is distributed all over the world except Madagascar and the Australian region, and contains about forty-one species, of which there are six found in South Africa as described below.
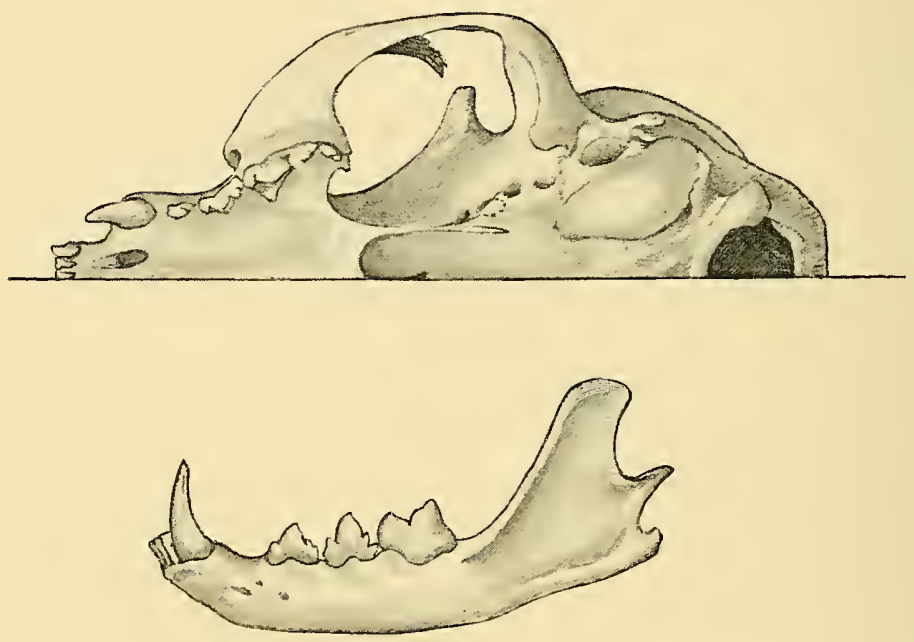

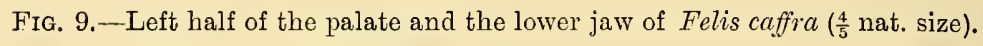

Key of the South African Species.

A. Ears rounded without a pencil of long hairs; 3 upper premolars.

a. Of large size; head and body about $6 \frac{1}{2} \mathrm{ft}$. in

length; of uniform colouration with a mane

well developed in male ............................
b. Of intermediate size; head and body about

$4 \frac{1}{2} \mathrm{ft}$. ; body covered with rosette like spots ... F. pardus, p. 34 .

c. Smaller; head and body less than $3 \frac{1}{2} \mathrm{ft}$.

$a^{1}$. Rufous, with solid black spots; head and body about $3 \mathrm{ft} .3 \mathrm{in}$.

F. serval, p. 38. 
$b^{1}$. Pale, with solid black spots; head and body about 20 in.

F. nigripes, p. 40.

c. Grey, without spots; limbs with bands or traces of bands

F. caffica, p. 42.

$B$. Ears pointed and provided with long pencil of hairs; as a rule two upper premolars only; body unspotted, rufous

F. caracal, p. 44.

\section{Felis leo. The Lion.}

Felis leo, Linnaeus, Syst. Nat. 12th ed.i, p. 60 (1766); Thunberg, Mem. Acad. Petersb. iii, p. 303 (1811); Smuts, Enum. Mamm. Cap. p. 25 (1832); A. Smith, S. Afi. Quart. Journ. ii, p. 120 (1834); Elliot, Monogr. Felidae, pl. i, (1883) ; Lydekter, Handb. Carnivora i, p. 27, pls. i-ii, (1895).

Leo barbarus, Layard, Cat. Mamm. S. Afr. Mus. p. 36 (1861).

Litera'ure.-Tachard (1685), p. 90, note on occurrence near Cape Town; Kolben (1731), ii, p. 94, found close to Cape Town in 1707; Sparrman (1785) ii, p. 48, observations on habits; Paterson (1790), p. 12, occurrence in Caledon and Oudtshoorn in 1777-8; Thumberg (1795) ii, p. 69, on habits and occurrence on the Oliphants River in Clanwilliam in 1775; le Vaillant (1796), i, p. 229, also met with on the Oliphants River; Barrow (1801), pp. 72, 346, met with lions in Uitenhage and Nainaqualand; Burchell (1822), i, p. 287, ii, p. 81, lions on the northern karoo in Carnarvon and Hanover; Steedman (1835), i, pp. 120, 209, and ii, pp. 14-15, occurrence in various parts of the Colony in 1830-31, with note on habits ; Harris (1838), pp. 85, 163, 371, met with lions in Bechuanaland and in the Western Transvaal, and gives a description; Harris (1840), figured pl. xxix ; Delagorgue (1847), ii, p. 153, habits in Natal ; Methuen (1848), pp. 80-2, habits and occurrence in Griqualand West; Cumming (1855), i, pp. 176, 193, a good account of habits and hunting; Livingstone (1857), pp. 11, 138, adventures with lions and account of habits; Hall (1857), p. 4, distribution in South Africa at that date; Grout (1862), p. 289, still existing in Natal; Andersson (1873), pp. 1-238, adventures with lions ; Drummond (1875), pp. 222-286, lion-hunting in Zululand; Bisset, Sport and War (1875), account of lion shooting in the Colony in 1839, and in Natal in 1865; Selous (1881), pp. 25, 257, habits and hunting of lions ; Holub (1882), ii, p. 100, observations on the habits; Theal (1888), i, p. 254, ii, p. 7, lion incidents near Cape Town at the end of the 17 th century; Bryden (1889), p. 290, extinction in the Colony; Nicolls and Eglington (1892), p. 80, habits, distribution, and description; Bryden (1893), p. 496, past and present distribution; Selous (1893), pp. 147, 165, 444, 467, various notes and measurements; Selous and Jackson (1894), chap. xii, and xvii, on lion hunting; Millais (1895), pp. 80, 185, habits, occurrence and sketches in the eastern Transvaal; Kirby 
(1896), pp. 390, 551 on hunting, native names, habits and dimensions in the Eastern Transvaal ; Kirby (1899), p. 321, distribution in the Beira-Zambesi country; Kirby (1899a), p. 545, habits and shooting in South Africa.

Vernacular Naues.-Leeuw of the Dutch colonists; Ingonyama of Amaxosa (Stanford) ; Ingonyama, Imbubesi or Imbubi of Swazis and Zulus (Kirby); Tau of Bechuanas and Basutos (Bryden and Kirby).

Description.-Male: General colour tawny yellow, the hair being very short, yellowish and here and there dark tipped; no spots or stripes; below a little lighter coloured; a mane of long hairs of the same colour extends above from a point on the head between the ears to the middle of the shoulder and round the neck to just between the front legs; pupil round; ears with a black patch at the base outside, tips and insides tawny yellow; a yellow tuft of long hairs more or less developed, at the elbow-joint of the fore limbs; tail long and tapering with a horny tip covered with a thick tuft of black hairs; naked skin of the toes black.

The female differs in the complete absence of the mane, and the young animals of both sexes show very distinct signs of darker spots, especially about the limbs.

The skull of the lion is large and massive, with broad zygomatic arches, and well-marked sagittal and occipital crests for the attachment of the powerful jaw muscles; it can be distinguished from that of the tiger, with which alone it could be confused by the fact that the posterior processes of the nasal bones do not, or only just extend as far back as the frontal processes of the maxillae, and that the distance between the anterior parietal suture and the postorbital process is comparatively short, so that the lion's skull may be described as short-waisted as compared with the long-waisted skull of the tiger.

Dimensions.- Of a mounted example from Mashonaland in the South African Museum; head and body $6 \mathrm{ft} .6$; tail $2 \mathrm{ft} .6$; hind foot from heel about $1 \mathrm{ft} .4$; head from ear-opening to tip of nose $12 \mathrm{in.}$; height at shoulder $3 \mathrm{ft} .3$.

Selous gives $10 \mathrm{ft} .3,10 \mathrm{ft} .6,10 \mathrm{ft} .9,10 \mathrm{ft} .10$, and $11 \mathrm{ft} .1$, as the dimensions of pegged out skins, and the weight of a male not full grown 385 lbs., quite full grown as 408 lbs.

Kirby gives $10 \mathrm{ft} .7[7 \mathrm{ft} .2+2 \mathrm{ft}$. 11] as the length of the largest lion shot by him measured in the flesh along the curves of the body, the skin of the same individual, measured when pegged out $11 \mathrm{ft} .4$, and the skull $16 \mathrm{in}$. in length; a lioness measured in the same way $9 \mathrm{ft} .2$. 
Measurements of a skull in the South African Museum are: total length 13; from incisors to the foramen magnum 11; breadth across the zygomata 8 ; upper cheek teeth 5 .

Distribution.-The lion was formerly found throughout the whole of Africa, from Algeria to Cape Colony, though now exterminated in the more thickly settled districts; in Asia it ranges through Mesopotamia and Southern Persia into North West India, where, however, it is now very rare and likely soon to become extinct. Within historic times it was found in Asia Minor and South-eastern Europe, and the presence of bones and teeth in caverns and superficial deposits prove that it was formerly abundant throughout Western Europe as far as the British Isles.

In South Africa the lion is now extinct south of the Orange River, but it is still to be found in German South-west Africa, in the Kalahari, in the eastern part of the Transvaal, and throughout Rhodesia, Zululand and Portuguese territory. A lion was killed at Springs near Johannesburg in 1897, and another was reported from near Heidelburg, south of Johannesburg, in the Cape Times newspaper of Feb. 8, 1898; a third was said in the issue of the same paper for July, 20, 1897, to have been killed close to Bulawayo.

With regard to past times-Kolben (1731), states that lions were not uncommon near Cape Town as late as 1707, Sparrman (1785), Paterson (1790), Thunberg (1795), and Barrow (1801), all met with these animals as soon as they got arvay from the immediate neighbourhood of Cape Town especially on the karoo and in Uitenhage. The last record I have met with of the occurrence of a lion south of the Orange River is of one killed with assegais near Commetjes Post on the eastern frontier in 1842, as noted by Hall. General Bisset shot a lion in Natal in 1865, which is probably the last record for that Colony. The South African Museum possesses a mounted pair killed by Mr. Selous in Mashonaland and Manicaland in 1888 and 1892, and a skin recently obtained from Lake Ngami.

Varieties.-Most hunters assert that there are more than one kind of lion, some distinguishing two, some three, some more species; the distinctions on which these are based are slight variations in colour and especially variation in the development and colour of the mane; the Boers distinguish two maned varieties, the "Zwart-voorlijf" and the "Geel-voorlijf" i.e., the black and yellow maned; Selous (1881), has, I think, clearly shown that these varieties are individual and not in any sense geographical, and that black-maned and yellow-maned and even maneless lions may be born among the same litter. 
Habits. - The lion has been known so long, and so much has been written on it that it is difficult to sift out a short account from such abundant material. The following is based chiefly on the works of Gordon-Cumming and Selous, both of whom appear to have observed this animal closely in its native haunts.

The lion inhabits sandy plains and rough rocky places covered with brush or thorny thickets; it is frequently seen in dry, or nearly dry river beds, on either side of which are beds of reeds and bushes, in which it can conceal itself. Lions are sociable animals and are often seen in small troops of from about six to a dozen individuals consisting of perhaps two adult males, three or four adult females, the remainder of cubs of varying ages.

Although this species has a round pupil it is a distinctly nocturnal animal, being seldom seen during the day, when it usually rests concealed. Kirhy says that in cloudy weather, in unfrequented districts it is sometimes seen in the day; and Selous mentions, as a very unusual sight, the fact of his seeing, during broad daylight, one hunting a kudu.

The roar has often been described, and while to some people it appears most majestic, resembling distant thunder, to others, as for instance, to Dr. Livingstone, it resembled the bray of an ass and was indistinguishable from the voice of the ostrich. GordonCumming describes it as consisting of "at times a low deep moaning repeated five or six times, ending in fairly audible sighs, and at other times of loud deep-toned solemn roars repeated in quick succession, each increasing in loudness to the third or fourth, when it dies away in five or six low muffled sounds, very much resembling distant thunder."

Its pace is a slow, loose-jointed walk, the head being held quite low, not raised up as generally represented in pictures. When excited and charging it progresses by a series of bounds or springs, and its pace is as great as that of a horse ; this, however, only lasts a short time as, if not successful at first, it very soon tires of the pursuit.

It is generally supposed that the lion does not climb trees, but that this is not always so has been shown by $\mathrm{Mr}$. Kirby, who gives an instance of a lioness doing so.

Its food consists of the larger herbivorous animals, and as these are killed off, it retreats into less settled and hunted districts. The buffalo is perhaps the most frequent victim, but all the antelopes, from the eland to the pallah, zebras and even giraffes, are 
easily overcome; the only animals that apparently escape its depredations are the rhinoceros, hippopotamus and elephant. The cattle, and especially the donkeys, of the hunter and trader are frequently carried off at night, as is related in nearly all books of South African travel. For all this the lion by no means disdains meat which has been shot by sportsmen, even when it has become somewhat putrid.

They sometimes become regular man-eaters, though this is not nearly so common an occurrence as in the case of tigers in India. This is probably owing to the fact that the natives of Africa are braver and better armed than the natives of India, and soon club together to hunt out and destroy any lion manifesting these proclivities. In such cases as I have seen described the animal was always a very old one, and the teeth so much worn down as to be nearly useless for catching wild animals.

Cannibalism occurs occasionally: Andersson witnessed the contest of a lion and lioness over the carcase of an antelope, resulting in the death of the latter and in the devouring of her by her mate.

The lion usually commences its meal by tearing open the belly of its victim and removing the entrails; these, all observers are agreed, it buries near the kill, whether it eventually eats them or whether it buries them merely to conceal their odour, which might attract other animals to the kill, seems uncertain. They drink, as a rule, once a day, in the evening, between sunset and 10 p.m.; also sometimes in the morning after eating all night; they lap loudly like a cat.

The lion is monogamous; the period of gestation, as observed in the Dublin Zoological Gardens, * is about one hundred and eight days; in South Africa two to four cubs are born, usually three, during the warmer season between November and March; the eyes are said by most authors to be open at birth. The mother exhibits great devotion towards her young and is always more dangerous to meddle with at that time.

Accounts of the character of the lion differ very considerably; by the older authors it was regarded as the noblest of animals, while Livingstone and many others have stigmatised it as a skulking coward. The truth, no doubt, lies between the two extreme views; it is doubtless cowardly and lazy unless roused, only a very few instances being known of its attacking human beings 
unprovoked and there is no doubt that it will shun a conflict with man when possible.

This animal is not tenacious of life, and is easily killed as compared with the larger antelopes; hunting it with dogs and horses is comparatively safe; even on foot it is not reckoned by sportsmen very dangerous; the great risk is in the following up of wounded animals into the bush, and it is in doing this that so many fatal accidents have occurred. Notwithstanding what has been said the lion is considered by Selous to be the most dangerous of all South African animals.

According to Selous the flesh is very palatable, resembling veal.

\section{Felis pardus. The Leopard.}

Felis pardus, Linnaens, Syst. Nat. 12th ed., i, p. 61 (1766); Thunberg, Mem. Acad. Peters. iii, p. 303 (1811) ; Layard, Cat. Mamm. S. Afr. Mus. p. 38 (1861); Gunther, Proc. Zool. Soc. 1882, p. 312 [pale var.] ; Trimen, ibid. 1883, p. 535 [small black-spotted var.]; Ellliot, Monogr. Felidae, pls. vi, vii (1883); Gunther, Proc. Zool. Soc. 1885 , p. 243 pl. xvi [small black-spotted var.] ; $i d$. ibid. 1886, 203 [complete melanistic var.] ; Lydekker, Handb. Carnivora, i, p. 71. pl. v (1895).

Felis leopardus, Schreber, Saïgeth. iii, p. 387, pl. ei (1778); Smuts, Enum. Mamm. Cap. p. 27 (1832); A. Smith, Descr. Cat. S. Afr. Mus. p. 7 (1826) ; id. S. Afr. Quart. Journ. ii, p. 121 (1834); Layard, Cat. Mamm. S. Afr. Mus. p. 38 (1861).

Literature.-Kolben (1731), ii, p. 97, described as being found near Cape Town in 1705; Burchell (1822), i, p. 16, note of occurrence near Cape Town in 1810 ; Harris (1840), figured on pl. xxviii, fig. 1; Drummond (1875), p. 288, habits in Zululand; Nicolls and Eglington (1892), p. 84, deseription, distribution and habits; Bryden (1893), p. 498, distribution in Bechuanaland; Kirby (1896), pp. 178, 239, 551, account of hunting, variation, native names and habits in Eastern Transvaal ; Kirby (1899), p. 321 distribution in the Beira-Zambesi country; Kirby (1899a), p. 568, general account of habits and hunting.

Vernacular Nanes.-Tijger or Vlackte tijger of Dutch Colonists; Ingwe of Swazi, Zulu, and Amaxosa; Inkwi of Basuto (Kirby).

Description.-Ground colour yellow of varying intensity, paling below to pure white, covered all over with black spots of unequal size, but not usually exceeding one inch in diameter; the fur is very close, short and thick in South African skins; on the back and sides of the body, the spots consist of three to five clumps of 
black, forming an incomplete ring with a yellow centre usually darker than the ground colour; on the head and limbs the spots become smaller, and gradually lose their light centres; ears rounded, black at the base and extreme tip, subterminally tawny; tail of varying length, not so long as the body, tawny above, white below, spotted with large irregular black patches, which become larger towards the tip where they form two or three incomplete irregular rings; tail not tufted or pointed. Cubs with rather longer hair and less bright coloration, the spots being more indistinct.

The skull of the leopard, besides being very much smaller than that of the lion, is more arched from behind forwards, so that, as a rule, when the lower jaw is attached and the skull placed on a flat surface, the hinder part touches that surface.

Dimensions.-Leopards vary considerably in size ; the following measurements are taken from a large mounted specimen in the South African Museum, shot many years ago at Camps Bay, close to Cape Town. Head and body, $5 \mathrm{ft}$; tail, $2 \mathrm{ft}$. 10; hind foot, 8.5 in. ; from ear opening to tip of nose $7.5 \mathrm{in}$.

Kirby (1896) gives the dimensions of the two varieties, which he distinguishes, as follows:-Hill variety: head and body, $3 \mathrm{ft}$. 7 ; tail, $2 \mathrm{ft}$. 10. Plains or low country variety: head and body, 4 ft. 4 ; tail, 2 ft. 6.

Dimensions of a skull in the South African Museum. Total length $8 \cdot 25$, width across the zygomatic arches $5 \cdot 0$, length of upper cheek teeth $3 \cdot 10$. Mr. Kirby gives the weight of an adult as from 180 to $190 \mathrm{lbs}$.

Distribution.--The leopard is the most widely spread of all the cat family; it is found over the whole extent of Africa, and also throughout the greater part of Asia, being absent from Siberia and the high plateau of Thibet alone; formerly it ranged over Western Europe, as is shown by the fossil remains in the bone caverns of Great Britain, Spain, France and Germany.

In South Africa the leopard, or tiger, as it is invariably called by all the Colonists, is found almost everywhere, where suitable situations exist. A specimen already mentioned above was killed not many years ago within two miles of Cape Town, at Camps Bay, and the South African Museum has recently acquired a young individual from Jonker's Hoek in the Stellenbosch division, not thirty miles from Cape Town, presented by Mr. F. G. Watermeyer; elsewhere it is found throughout the country up to the Zambesi. 
Yarieties.-The leopard is an animal which varies a good deal both in size and in the colour and distribution of its markings, so that it has always been a doubtful question as to the number and validity of the species. Both in Africa and India sportsmen have been in the habit of distinguishing a smaller "hill" and a larger "plains" variety, the cistinctions between which have been clearly pointed out by Kirby. The smaller has a rich buff ground colour and long thick fur, and the rosettes of the back run together somewhat so as to form several continuous stripes from the nape of the neck to the middle of the back. The animal measures on an average $6 \mathrm{ft}$. 5 , of which the tail forms $2 \mathrm{ft}$. 10. The larger low country variety has very short fur, with a pale fawn ground, and no sign of the black stripes along the back; it is a lankier, longer animal than the other, and measures about $6 \mathrm{ft}$. 10, of which the tail forms about $2 \mathrm{ft}$. 6 .

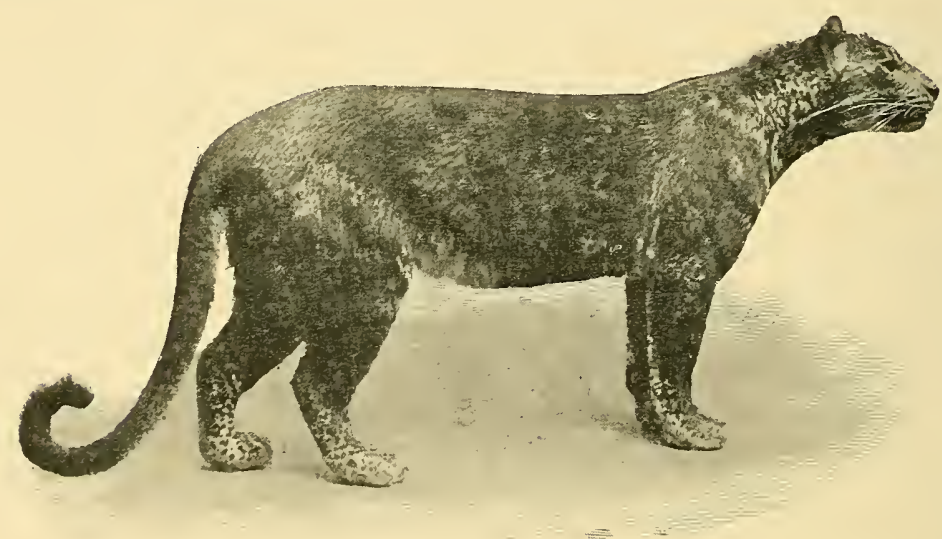

FIG. 10.-The Leopard (Felis pardus), from a photograph of the mounted specimen of the black variety in the South African MIuseum.

Mr. Kirby, however, further states that these two described varieties are merely the extremes, and that intermediate forms are common, even commoner than the extremes, and that in no way can the two be considered as different species or even geographical races.

More distinct variations of the leopard sometimes occur. Dr. Gunther has described a very pale sandy variety from Matabeleland; but perhaps the most remarkable form is one noticed by Gunther 
and Trimen, of which three or four specimens have been obtained, all from the neighbourhood of Grahamstown, and of which an example has recently reached the South African Museum.

This peculiar form shows no trace of the rosettes, but is covered, especially on the head and along the back, with a large number of small round black spots, which in one case were so numerous as to be fused together, so that the whole of the back and sides of the animal was quite black, while below and on the lower part of the legs the spots remain separate. In fact, this variety must be accounted as much a black "leopard" as any of those not infrequently found in Southern Asia. The difference, however, between the two varieties is an essential one, as in the Asiatic black leopard the melanism is caused by the darkening of the tawny ground colour, and the rosettes can be seen, somewhat like spots on watered silk in certain lights; whereas in the African variety the melanism seems to be caused by the great increase of the spots, which finally fuse to form a uniform black livery.

Dr. Blanford, in his account of the Indian Mammals, asserts that African leopard skins can be always distinguished from those of Asia by their smaller and more solid spots. If this is the case, it may perhaps be necessary to distinguish the African form as a geographical sub-species, which should be called Felis pardus nimr of Hemprich and Ehrenberg.

Habits. - The leopard is usually found in rocky situations, sometimes in dense scrub near krantzes or precipices, sometimes on rocky hills, where there is hardly any vegetation at all, in which case it makes its home in caves. It usually goes singly or in pairs, though sometimes small troops of four or six are seen together, probably consisting of one family; it is thoroughly nocturnal, much more so than the lion. All observers agree in saying that it is a far more silent animal than the lion or even the tiger, its voice when heard being something between a hoarse grunt and a cough; it further differs from the lion in the great facility with which it is able to climb even high trees, and when attacked it frequently seeks refuge there. When pressed the leopard takes to the water and can swim well.

The food of the leopard consists of any animals it can overpower; in the Colony, baboons and dassies (Procavia); in the Eastern Transvaal, according to Kirby, cane-rats (Thryonomys); duikers (Cephalophus); bush-pigs (Potomochoerus) and bushbucks (Tragelaphus) among wild animals; kids, lambs, sheep and calves 
among domestic animals. In India it seems to have a particular predilection for dogs of all kinds, but $I$ have not observed this noticed among writers on African sport.

The leopard is always credited with the love of killing for killing's sake; it seems likely, however, that when a number of victims have been slain, the destroyer would return and devour the whole of them if allowed to do so, more especially as it appears, notwithstanding what Drummond says to the contrary, to be very fond of carrion, even when putrid.

This animal has a favourite custom of placing its prey up in a tree-fork until rotten, and the late Mr. Cloete of Bowden, has written to me that he has found the rotten remains of an almost devoured bushbuck 12 or $14 \mathrm{ft}$. above the ground in a euphorbia tree.

I have never come across any account of a true man-eating leopard in Africa, such as undoubtedly exists in India, though many fatal accidents have occurred through these animals.

The usual number of cubs at birth appears to be three, though from four to six have occasionally been observed; in the Eastern Transvaal they are born usually between October and December.

In disposition the leopard is extremely active, wary, and bloodthirsty. It is so cunning that instances frequently occur of one approaching quite close to a camp, without disturbing the occupant, who only discovers the nature of the intruder by the spoor marks next day. When brought to bay or wounded it will charge with the greatest pluck, and show, for its size, as much courage as a lion.

\section{Felis serval. The Serval Cat.}

Felis serval, Erxleben, Syst. Regn. Anim.p. 523 (1777); Smuts, Enum. Mamm. Cap. p. 28 (1832) ; A. Smith, S. Afr. Quart. Journ. ii, p. 122 (1834); Layard, Cat. Mamm. S. Afr. Mus. p. 39 (1861); Elliot, Monogr. Felidae, pl. xxvi (1883); Lydekker, Handb. Carnivora, i, p. 135 , pl. xiv (1895).

Felis capensis, Gmelin, Linn. Syst. Nat. i, p. 81 (1788); Thunberg, Mem. Acad. Petersb. iii, p. 304 (1811) ; A. Smith, Descr. Cat. S. Afr. Mus. p. 9 (1826).

Literature.-Kolben (1731), ii, p. 127, notice of a wild cat, obviously the Serval; Sparrman (1785), ii, p. 268, short notice of the Serval; Grout (1863), p. 291, described as inhlozi; Nicolls and Eglington (1892), p. 87. 
description and distribution; Kirby (1896), p. 552, account of in Eastern Transvaal; Bryden (1899a), p. 581, general account.

Vernacular Names.-Tijger-bosch-kat or Tijger-kat of Dutch; Indhlozi of Amaxosa (Stanford); Indhloti of Swazis and Zulus (Kirby); Tlodi of Basutos (Kirby); Tali of Bechuanas (Bryden).

Description.-General colour fulvous, getting a little lighter posteriorly and on the flanks; below, chin, belly and inside of legs, white or nearly so; fur thick and somewhat woolly, much more so than in the leopard; body covered with black spots, which on the nape and upper part of the shoulder coalesce to form six more or less well-defined black lines; head rounded, with a few very small black spots on the cheeks and forehead, but no defined markings; ears long and somewhat pointed, more so than in the leopard, black behind with a subterminal fulvous spot; legs long, spotted like the back and with a very characteristic black horizontal band inside about the region of the elbow and knee joints; tail very short, less than half the length of the head and body, the spots at the base large and gradually forming indistinct rings towards the tip.

The skull seems small for the size of the animal; it differs from that of the leopard in having that portion of the skull which forms the orbital region very much narrower than the portion behind the post-orbital bony processes, whereas in the leopard these two portions of the skull are of approximately equal breadth; except in size and that the nasals are somewhat longer and more truncate, I can detect no distinction of importance from the skull of $F$. caffra.

Dimensions.-Measurements of a mounted specimen in the South African Museum; head and body $3 \mathrm{ft} .1 \cdot 5$, tail 12, hind foot $7 \cdot 5$; head from ear opening to tip of snout $5 \cdot 5$.

Kirby gives the total length of a specimen as $3 \mathrm{ft}$. 8 , and the height at the shoulder $1 \mathrm{ft}$. 8 .

A skull in the South African Museum measures, total length 4.35 ; greatest width $2 \cdot 90$, upper cheek teeth $1 \cdot 75$.

Yariations.--Like the leopard, this animal varies somewhat in the intensity of its coloration. Kirby records a very dark coloured individual almost a melanism, from the Eastern Transvaal; while Mr. H. C. V. Hunter shot near Mt. Kilima-njaro in East Africa, a completely black variety in which, like the Asiatic black leopard, the spots could be seen shining through in certain lights.

Distribution,-The serval seems to be found throughout Africa 
from Algeria to the Cape, but does not extend its range like the two previous species, to the neighbouring continent of Asia. It occurs everywhere in South Africa, though nowhere does it seem to be common; it is said to be found in Namaqualand and in the Transkei, in German South - west Africa, the Transvaal and Rhodesia. The South African Museum possesses an example obtained near Somerset West, not far from Cape Town, presented by Sir James Sivewright in 1898, and also a skin recently obtained at Potchefstroom, in the Transvaal, where it is not uncommon.

Habits.-This wild cat perhaps partly due to its retiring habits, partly to its scarcity, has been but rarely noticed by African observers; it appears to frequent long grass, reeds and bushes, especially in the neighbourhood of small streams and rivers. When disturbed by dogs it usually takes to a tree, where it remains at bay; its food consists of small mammals, such as hares and canerats (Thryonomys), also of birds, and it further is said not to disdain birds' eggs; it is strictly nocturnal in its habits and a great poultry thief.

Sir Harry Johnston relates that the kittens are easily reared and stand confinement well, and that they become tame only to a certain extent, never so much so as those of the leopard.

\section{Felis nigripes. The Black-footed Wild Cat.}

Felis nigripes, Burchell, Travels ii, p. 592 (1824); A. Smith, S. Afr. Quart. Journ. ii, p. 123 (1834); Layard, Cat. Mamm. S. Afr. Mus. p. 39 (1861) ; Matschie, S. B. Nat. Fr. Berlin, p. 258 (1894); Brydcn, Great and Small Game, p. 582 (1899).

Vernacular Names.-Kakikaan of Bechuanas (Burchell); Tsipa in the Kalahari Desert (Livingstone).

Description.-Slightly smaller than the domestic cat; general colour pale tawny, or sandy, becoming almost white on the chin and belly and inside the legs; body covered with small rounded very dark brown or black spots, which on the nape and shoulder coalesce into rather vague longitudinal stripes; top of the head dark speckled brown with short close hairs, becoming paler on the cheeks along which are two ill-defined blackish markings; ears moderate, slightly pointed, of a uniform speckled brown, the anterior 
edge with long upright white hairs ; fore and hind limbs with three more or less well-defined black rings encircling them ; soles of both pairs of limbs quite black; tail short with ill-defined black spots and a black tip.

Skull resembling that of $F$. caffra, but smaller.

Dimensions.-From an old mounted specimen; head and body $20 \cdot 0$, tail $6 \cdot 0$, hind foot $4 \cdot 0$; head from ear opening to tip of nose 2.75 ; skull length 3.20 ; extreme breadth 2.28 ; length of upper cheek teeth $1 \cdot 25$.

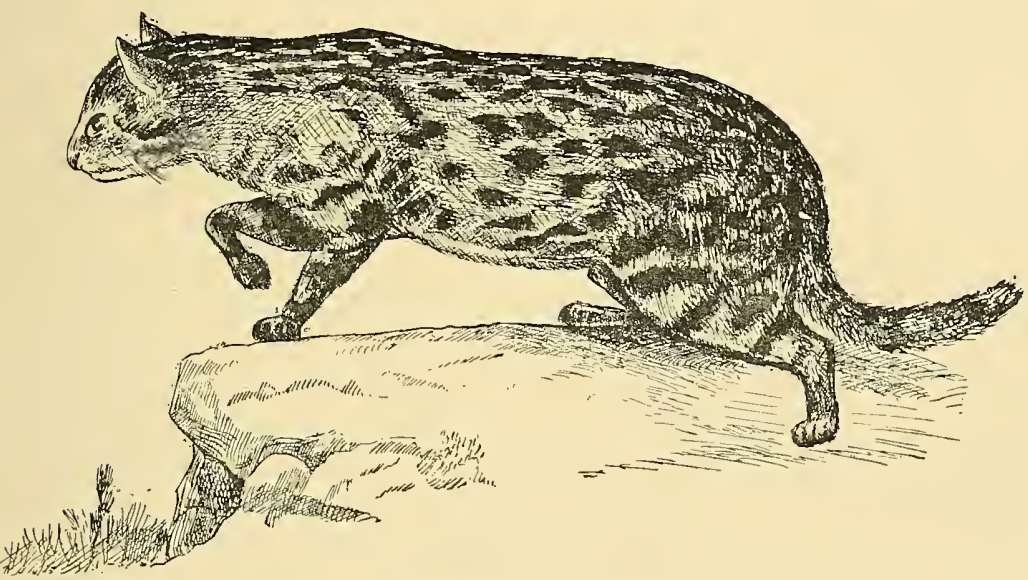

FIG. 11.-The Black-footed Cat (Felis nigripes).

Distribution.-This wild cat seems to be only found in the Kalahari Desert and Bechuanaland, and is very little known. It was described by Burchell from an imperfect skin, which he saw at Litakun, near Kuruman, forming part of a cloak or kaross. There is a single very old specimen in the South African Museum, obtained at Kuruman many years ago by Dr. Moffat, and there are specimens in the British and Berlin Museums. Dr. Gray, in his catalogue, placed this species as a synonym of $F$. caligata $(=F$. caffra), in which he was followed by Elliot in his monograph, and it is perhaps in consequence of this that the species has been so often overlooked. It is much more like a very small edition of $F$. serval, and bears no external resemblance to $F$. caffra. 


\section{Felis caffra. The Caffer Cat.}

Felis caffra, Desmarest, Mammal. Suppl., p. 540 (1822); A. Smith, Descr. Cat. S. Afr. Mus. p. 10 (1826); id. S. Afr. Quart. Journ. ii, p. 123 (1834) ; Layard, Cat. Mamm. S. Afr. Mus. p. 39 (1861); Elliot, Monogr. Felidae. pl. xxxi (1883); Lydeklier, Handb. Carnivora i, p. 155, pl. xix (1895).

Felis chaus, apud Thunberg, Mem. Acad. Petersb. iii, p. 304 (1811) [nec Guldenst.]

Felis caligata, apud Smuts, Enum. Mamm. Cap., p. 30 (1832); [nec Temminck].

Literature.-Nicolls and Eglington (1892) p. 89, description; Kirby (1896), p. 552 native names and habits in Eastern Transvaal ; Kirby (1899), p. 322, distribution in the Beira-Zambesi district; Bryden (1899a), p. 583, habits, \&c., \&c.

Vernacular Names.-Bull Head or Wild Cat, Wilde Kat or Graauwkat of the Colonists; Ingada or Inxataza of Amaxosa (Cloete); Impaka or Imbodhla of Swazis and Zulus (Kirby).

Description.-General colour speckled greyish brown, the fur being dark slate for the basal third, then yellowish, the tips ringed black and white, below becoming yellowish owing to the absence of the ringed tips; along the middle of the back a line of darker fur with darker under-fur; head dark, speckled with irregular darker marks, and a dark spot in front of each eye; chin white; whiskers chiefly white with some black bristles; ears rounded, reddish brown posteriorly, a few long white hairs along the front inner margin; fore and hind limbs darker than the body, ringed with about five black bars ranging in distinctness and also varying in development in different individuals; elbow joint of fore limb and soles of fore and hind feet black, tail short, not half the length of the head and body, with a dorsal band, three rings and tip black.

The female is lighter in colour and the black is not nearly so marked ; the kittens show very distinct traces of transverse stripes.

Skull (fig. 9, p. 28), intermediate in size between those of the serval and the black-footed cat, with narrow, pointed and rather short nasals.

Dimensions.-From a mounted male, head and body $2 \mathrm{ft.} 1$; tail 9.5 ; hind foot 5.75 ; head from ear opening to tip of nose 3.25 ; skull, total length 4.85 ; breadth $2 \cdot 60$; upper cheek teeth 1.50 .

Yariation.-Kirby, p. 552, and also Mr. Clocte in his notes, communicated to me, both distinguish two varieties, a larger and smaller race, the former with a shorter tail, more tawny colour and 
less black soles; but although no doubt individuals vary a good deal, especially through age and sex, no sufficient grounds have been shown for distinguishing two species in South Africa.

Whether the caffer cat should be distinguished from that of Abyssinia and North-east Africa (Felis caligata of Temminck and Felis maniculata of Cretzschmar), is a difficult question, and only a comparison of a large number of skins and skulls from various localities can settle this matter satisfactorily.

Distribution. - If the forms above-mentioned are to be considered as specifically identical with $F$. caffra, this species has a very wide distribution, including Syria, Arabia, Sardinia, and Africa from Algeria to the Cape. In South Africa it appears to be fairly abundant everywhere, and it is quite common throughout the Colony, even in the immediate neighbourhood of Cape Town; there are specimens in the South African Museum from the Cape, Paarl, Worcester, Beaufort West, Middelburg and Namaqualand divisions of the Colony.

Habits.-Observers have not paid much attention to this wild eat, and the following account is derived chiefly from Kirby, and from manuscript notes sent me by the late Mr. Cloete, of Bowden.

The caffer cat is nocturnal, though sometimes seen in cloudy, cool weather, during the day time; usually, however, it spends the day among thick bushes, whence it is sometimes put up by parties out shooting; occasionally in an open country it takes refuge in the deserted earth of an ant-bear (Orycteropus).

Its food consists of small mammals, such as rats and mice, game birds to which it is very destructive, and occasionally the young of the smaller antelopes; it is also a great fowl-house raider. Layard mentions a case of thirty fowls belonging to the late Sir Thomas Maclear, being destroyed in a few days, at the Royal Observatory near Cape Town; occasionally too, it will attack lambs and kids; it does not appear to relish carrion.

The wild cat brings forth its young in holes under stones, or in thick bushes, the number of kittens being from two to four; it breeds freely with the domestic cat, and in many parts of the country it is difficult to keep the ordinary domestic tom cats, owing to the superior fighting powers of the wild cat which comes down around the farms during the breeding season. It is a very plucky and ferocious animal, caring little for man and his vicinity.

It has been maintained by many naturalists that the European domestic cat is chiefly derived from the north-eastern race of this 
species found in Egypt; at least, the domestic form is certainly not derived from the European wild cat (Felis catus). It is in any case certain that $F$. caligata is the species so thoroughly domesticated by the ancient Egyptians, and used by them for fowling purposes. These cats were also held sacred by the Egyptians, and enormous numbers of their bodies have been found preserved and embalmed in tombs, especially in the neighbourhood of Bubastis and BeniHassan in Egypt.

\section{Felis caracal. The Caracal.}

Felis caracal, Guldenstadt, Nov. Comm. Acad. Petrop. xx, p. 500 (1766); Thunberg, Mem. Acad. Petersb. iii, p. 304 (1811) ; A. Smith Descrip. Cat. S. Afr. Mus. p. 31 (1826); Smuts, Enum. Mamm. Cap. p. 29 (1832); A. Smith, S. Afr. Quart. Journ. ii, p. 125 (1834); Layard, Cat. Mamm. S. Afr. Mus. p. 40 (1861); Elliot, Monogr. Felidae, pl. xli (1883); Lydekker, Handb. Carnivora, i, p. 188, pl. xxiii (1895).

Caracal nubicus, Fitzinger, Sitzb. Akad. Wien lx, pt. i, p. 205 (1870). Felis nubica, Matschie, Sitzb. Ges. Naturf. Berlin, p. 114 (1892).

Literature.-le Vaillant (1796), ii, p. 284, obtained in Great Namaqualand; Daniell (1820), figured on pl. xii ; Livingstone (1857), p. 50, notice of, in the Kalahari, under name of "tuane"; Farini (1886), p. 461, in the Kalahari ; Nicolls and Eglington (1892), p. 88, description and distribution; Bryden (1893), p. 61, note on occurrence in Bechuanaland; Bryden (1899a), p. 585, general account.

Vernacular Names.-Lynx, Roode-kat or Rooi-kat of Colonists ; Incawa of Amaxosa (Cloete); Tuane of Bechuanas (Livingstone and Bryden).

Description.-General colour dark brick-red, darkest on the middle of the back; fur of the same colour throughout, though paler towards the roots, some of the hairs black tipped, especially along the middle of the back, below paler but hardly white; head the same colour as the back with a black ring round the eye, extending forwards to the nose; two small black spots on the forehead and on the cheek at the roots of the whiskers, which are black at the base and white beyond; the cheek markings are not always well defined; lower cheeks, chin, and upper throat white, ears acutely pointed, bearing a long tuft of black hairs intermingled with some white ones more than an inch in length; back of ears greyish black, formed also of black hairs with a few white intermixed, and a quite black patch at the base of the ears on the head; 
front of ears with long greyish hairs ; limbs long, of the same colour as the back; tail about one third of the length of the head. and body, also of the same colour as the back. Young with a more woolly coat, and often showing traces of spots.

Skull of about the same size as that of $F$. serval, but without the small anterior premolar of the upper jaw, so that there are only two premolars above instead of three.

This animal resembles the true lynxes of the northern hemisphere in its long limbs, its pencilled ears, and in the absence of the anterior upper premolar, but it has a longer tail, and has not the ruff round the neck, so characteristic of the true lynxes, and may therefore be regarded as an intermediate form between these animals and the typical cats.

Dimensions.-From a mounted specimen in the South African Museum; head and body $2 \mathrm{ft.} 11$; tail 11.50 ; hind foot 8.25 ; from ear opening to tip of nose $5 \cdot 0$; the largest specimen met with by Mr. Cloete measured $4 \mathrm{ft} .3$ from nose to tip of tail in the flesh; skull length 4.5 ; breadth $3 \cdot 20$; upper cheek teeth 1.80 .

Distribution.-Like most of the cat family, this species has a wide distribution; it is found throughout the western part of India, in Persia and Arabia, and also over the greater part of Africa, except perhaps on the west coast and in the south-eastern districts, such as Mozambique and Nyasaland.

In South Africa the rooi-kat appears to be found throughout the Colony, but is nowhere common; it is perhaps more abundant in the western portion, as it seems to be fairly common in German territory, the Kalahari and Bechuanaland, but gets scarcer to the eastward in Mashonaland, the Transvaal, and the Orange Free State, and I have not heard of its occurrence in Zululand or Natal. The South African Museum contains specimens from the Paarl and Uitenhage divisions.

Herr Matschie (see above) believes that the African race can be specifically distinguished from that of Asia; if this is so the name of the former will be $F$. nubica.

Habits.-For this species again my chief sources of information are the notes of Mr. Cloete. According to this observer the rooi-kat is found in mountainous, fairly open country, spending the day in bush or kloof, and coming out abroad chiefly at night, though should temptation, in the form of a convenient flock of sheep or goats offer, it will not hesitate to attack during the day. When pursued with dogs it usually takes refuge in a tree; the male will, 
however, sometimes face dogs in the open, standing at bay, scratching, spitting and "kaahing." It preys on small antelopes and often ravages sheep-kraals, and if lambs or kids are not available, will occasionally attack a full grown sheep. Mr. Cloete once found an entire mungoose (Herpestes pulverulentus), in the stomach of an individual shot by him.

Two to three young are usually born, though $\mathrm{Mr}$. Cloete relates a case of finding five young ones of the same age in a hole of a tree.

Like other wild cats, the rooi-kat is exceedingly fierce and bold, especially the female in defence of its young.

The skin of the rooi-kat is highly prized by the Bechuanas for making rugs or karosses, the value of which is as much as $£ 4$ or $£ 5$. These karosses are said to be a remedy for rheumatism when used as blankets, and the fat of the animal is also used as an ointment for the same purpose.

In Persia and India the Caracal is known as the "siyah-gush" (blackears), and is trained for hunting and capturing birds, especially pigeons.

\section{Genus CYNAELURUS.}

Cynailurus, Wagler, Nat. Syst. Amphib., p. 30 (1830) Type. Gueparda, Gray, List Mamm. Brit. Mus., p. 46 (1843)

This genus is closely allied to Felis; it differs from it in having the claws less curved, and hardly at all retractile, so that they are always visible; the dentition is the same as that of Felis, i.e., i. $\frac{3}{3}$, c. $\frac{1}{1}, \mathrm{pm} . \frac{3}{2}, \mathrm{~m} \cdot \frac{1}{1},=30$; the upper carnassial has no internal cusp, though still retaining the corresponding root; the posterior upper molar is more rounded and in a line with the other molars than in Felis.

One species only is usually recognised, though some naturalists regard the African hunting leopard as specifically distinct from that of India.

\section{Cynaelurus jubatus. The Hunting Leopard.}

Felis jubata, Erxleben, Syst. Reg. Anim. p. 510 (1777) ; Thunberg, Mem. Acad. Peters. iii, p. 304 (1811); A. Smith, Descr. Cat. Mamm. S. Afr. Mus. p. 8 (1826); Smuts, Enum. Mamm. Cap. p. 26 (1832); A. Smith, S. Afr. Quart. Journ. ii, p. 122 (1834). 
Felis guttatus, Hermann, Observ. Zool. p. 38 (1804).

Gueparda jubata, Layard, Cat. Mamm. S. Afr. Mus. p. 38 (1861).

? Felis lanea, P. L. Sclater, Proc. Zool. Soc. 1877, p. 532, pl. lv [Beaufort West]; Layard, ibid. 1878, p. 655; P. L. Sclater, ibid. 1884, p. 476.

Cynailurus jubatus, Elliot, Monogr. Felidae, pl. xliii (1883) ;

Lydekker, Handb. Carnivora, p. 202, pl. xxv (1893).

Cynaelurus guttatus, Nuack, Zool. Jahrb. iv, p. 163 (1889) [Kalahari].

Literature.-Harris (1840) figured on pl. xxviii, fig. 2; Drummond (1875), p. 289, described as maned leopard in Zululand; Farini (1886), p. 461, occurrence in Kalahari ; Nicolls and Eglington (1892), p. 86, description and habits; Bryden (1893), p. 60, on its occurrence in Bechuanaland; Kirby (1896), p. 553, vernacular names, habits, and measurements in the Eastern Transvaal ; Kirby (1899a), p. 587, general account.

Vernacular Names. - Luipard or sometimes Vlackte tijger of Dutch Colonists; Shlozi of Amaxosa (Cloete) ; Ngulule of Zulus (Drummond); Nki or Nkwani of Bechuanas (Smith); Ihlose of Swazi, Sigakaka of Basutos (Kirby).

Description.-General colour ochraceous yellow; fur smooth, not very long, and of the same colour throughout, covered everywhere with round black spots about half an inch in diameter at the largest; below lighter, almost white, with longer and more woolly hair and indistinct spots; round the neck and more so on the shoulders the hair is thicker, more woolly and upstanding, forming a kind of incipient mane; head short and thick, with small, rather indistinct spots, and a characteristic black line from the anterior angle of the eye to the edge of the lip in the neighbourhood of the canine tooth; pupil round; ear short and rounded, posteriorly with a black patch and tawny tip; chin white, unspotted, chest whitish and spotted; limbs very lank and long, spotted like the back; claws large and always visible, as they are only partially retractile; tail long, about half the length of the head and body, spotted at first, distally the spots tend to become rings, of which there are six to eight more or less imperfect; the tip of the tail is bushy and usually white.

In the young the fur is woolly, grey, and not so smooth, and the spots absent, or at least not nearly so well defined.

Skull much rounded above from behind forwards; inter-orbital and post-orbital portions of the skull very much wider than the corresponding parts in the leopard; orbits, sometimes at any rate, completed posteriorly; no internal cusp to the posterior upper pre- 
molar; the first upper premolar crushed in close between the canine and the middle premolar; the upper molar rounded and hardly transverse in position.

Dimensions. - Of a mounted female, head and body $3 \mathrm{ft} .11$; tail $1 \mathrm{ft} .11 .5$; hind foot 10.5 ; from ear-opening to tip of nose 7.5 in.; Kirby gives the total length of the largest met with by him as $7 \mathrm{ft}$. 6 , and the height at shoulders $2 \mathrm{ft}$. 6 to $2 \mathrm{ft}$. 8 . Skull length $7 \cdot 20$; breadth 2.75 ; length of upper cheek teeth 2.75 .

Yarieties.-An example of a pale variety, in which the ground colour is isabelline, the spots fulvous blotches, and in which the characteristic face streak is absent, was brought alive to the Zoological Gardens in London, and described and figured as Felis lanea by Mr. P. L. Sclater; another individual which, like the former, was obtained in the neighbourhood of Beaufort West, has long been in the South African Museum. It appears to me that these specimens are merely examples of an incipient albinism, just as the Grahamstown leopards described above are examples of commencing melanism, and that no specific differentiation can be established in either case.

Many authors have sought to draw a distinction between the hunting leopards of Asia and Africa; should this be correct the name C. guttata must be applied to our species or sub-species.

Distribution. - The hunting leopard inhabits much the same geographical area as the caracal; it is found throughout the greater part of India westwards of Lower Bengal, Persia, and Transcaspia. In Africa it is found in all the dryer parts, in Somaliland and British East Africa as far as Kilima-njaro, on the Nyasa-Tanganyka plateau and in parts of Angola, but it does not appear to enter the West African Forest region or the damper and more afforested parts of South-east Africa.

In the Colony it is found sparingly in the western and midland districts: north of the Orange River it is common in German territory, the Kalahari and Bechuanaland, and exists in Rhodesia, the Transvaal, Zululand and Natal, though now very rare in the latter Colony, and found only in the Drakensberg range. There are examples in the South African Museum from Beaufort West in the Colony, Natal, the Lydenberg district of the Transvaal and the Nyasa-Tanganyka plateau.

Habits.-The hunting leopard inhabits an open grass country where there are scattered bushes; it is never found in thick forest. It is less nocturnal than the leopard, and is frequently seen abroad 
in daytime, especially in cool and cloudy weather. When pursued it frequently takes to a tree; this was the case with both the individuals which came under the notice of Mr. Cloete in the Albany district.

The pace of this cat is very great. Both Kirby and all Indian naturalists are agreed that for a short distance at any rate it will easily outstrip a horse ; in fact, Mr. Blanford, in his "Mammals of India," states that it is the swiftest of all mammals. The voice of the adult is a deep grunt something like that of a leopard, while the young give vent to a whistling sound.

The prey of the hunting leopard consists of small quadrupeds, such as hares and small bucks, though Kirby relates the case of one which overpowered a female kudu. In the neighbourhood of farms it will attack goats, young cattle, and has even been known to destroy ostriches by driving them against the wire fences enclosing them.

The animal is a shy and secretive one, and is hence probably often overlooked and so reckoned rare; it has never been known to attack man, and in captivity is described as being gentle, timid and easily excitable.

In India it is often known as the cheetah or chita, though the name is not a good one, as it is also applied to the true leopard by the Hindustani-speaking natives. It is there frequently caught and tamed, and trained to hunt antelopes, and no native Rajah's court is complete without one or two. Only the adult animal is caught, as it is said that the young ones will never hunt unless taught by their mother.

After six months' training they are taken out hooded, usually in a cart, and loosed when within 200 to 400 yards of the antelopes; these are knocked over after a violent rush, and as many as six are sometimes secured in this manner in one day.

\section{Family VIVERRIDAE.}

Carnivores with a somewhat elongate head and body and short limbs, as compared with the previous family. The claws vary in retractibility, and so does the extent to which the soles are clothed with hairs, this depending on the fact that some of the family are digitigrade, some plantigrade. The number of digits is usually five. 
Auditory bulla externally constricted and divided into two chambers; alisphenoid canal nearly always present; the second pair of lower incisors usually extending above the level of the first and third pairs, premolars three or four, molars one or two, upper carnassial with no anterior lobe.

This family is confined to the Old World, and contains a good number of South African representatives.

\section{Key of the South African Genera.}

A. Claws strongly curved and more or less retractile; toes 5-5; perineal glands present.

a. Shorter animals with longer legs; soles completely clothed with hair Viverra, p. 50.

b. Slenderer animals with shorter legs; soles with a long narrow naked line Genetta, p. 52.

$B$. Claws exserted, lengthened, and not retractile; no perineal glands.

a. A bare line runs from the nose to the upper lip; toes $5-5$.

$a^{1}$. Soles naked or hairy; three to four premolars, if three, a space between the anterior one and the canine

Herpestes, p. 59.

$b^{1}$. Soles always naked; three premolars above and below, with no space between them and the canine in front

Helogale, p. 68.

b. No naked groove between the nose and the upper lip.

$a^{\mathrm{I}}$. Toes $5-5$.

$a^{2}$. Soles hairy; four premolars above and below

Rhynchogale, p. 69.

$b^{2}$. Soles bare; three premolars above and below

b. ${ }^{1}$ Toes 5-4; soles hairy ; four premolars above and below

$c^{\mathrm{l}}$. Toes 4-4; soles bare; three premolars above, three or four below.

Crossarchus, p. 72 .

Cynictis, p. 73.

Suricata, p. 76 .

\section{Genus YIVERRA.}

Viyerra, Limnaeus, Syst. Nat., 12th ed., i, p. $63(1766)$ V.'zibetha.

Animals with a somewhat short and stout body as compared with other members of the same group; limbs long, tail short and tapering; underside of tarsus completely clothed with hair; claws 
long, not very retractile, five in number on both feet; a pouch at the root of the tail for the storage of the secretion of the perineal glands.

Skull with auditory bulla small and somewhat pointed in front.

Dentition i. $\frac{3}{3}$, c. $\frac{1}{1}$, pm. $\frac{4}{4}, \mathrm{~m} . \frac{2}{2}=40$, as in Genetta, but the teeth stouter and less compressed and the third upper premolar with no internal cusp.

Only one African species, that below described, is known; four others are found in India and South-eastern Asia.

\section{Yiverra civetta. The Civet Cat.}

Viverra civetta, Schreber, Saïgeth. iii, p. 418, pl. exi (1778) ; Lydekker, Handb. Carnivora i, p. 211, pl. xxvii (1895); Kirby, Haunts of Wild Game, p. 553 (1896) [Eastern Transvaal].

Viverra orientalis, Matschie, Archiv. f. Naturg., p. 352 (1891); id. Saïgeth. Deutsch-Ost-Afrikas, p. 72. fig. 40 (1895).

Vernacular Naues.-Civet Kat of the Boers; Mpicamadhloti (that which puzzles spirits, in reference to its secretive habits) of the Swazis, Lisisi of the Basutos (Kirby).

Description.-General colour yellowish grey, covered with indistinct dark brown spots which tend on the anterior half of the body to form transverse markings; cheeks, throat and limbs black, upper lip and hinder cheeks white ; ears short, broad and rounded, with black bases and white tips; along the back from between the ears to the root of the tail a crest of much longer hairs, at first tawny yellow at their bases with black tips, getting entirely black towards the hinder part of the back; tail about half the length of the head and body, the proximal half with white rings interrupted above by a black dorsal band, the distal half quite black.

This description has been drawn up from a flat skin obtained by Mr. G.A.K. Marshall, near Salisbury; another one, also in the South African Museum, is very similar, but is without the crest and is perhaps that of a female.

Dimensions.-Of the flat skin described above, head and body $36 \cdot 0$, tail $18 \cdot 0$.

Distribution.-The civet cat is found throughout the tropical portion of Africa, and extends south of the Zambesi into Mashonaland and the Eastern Transvaal, where it has been met with by Messrs. Marsluall and Kirby. 
Habits.-These animals appear to be nocturnal and hence to be very seldom seen, and little is known about their habits. In the Transvaal, Kirby relates that they are found in the low country and in the kloofs, and were occasionally killed by his dogs. In tropical Africa they are frequently caught by the natives, and either kept in cages or tied up by a ring put through their noses, for the purpose of collecting the secretion which is stored up in the receptacles on either side of the tail ; this is the civet of commerce, formerly in considerable demand as a perfume.

The civet cat is a dire foe to poultry, and possesses to the full the bloodthirsty propensities of weasels and wild cats.

\section{Genus GENETTA.}

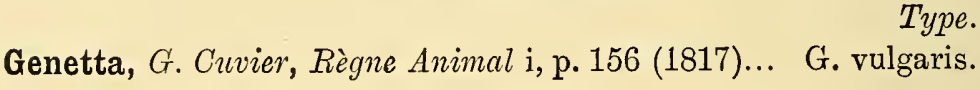

Elongated animals with slender bodies and long tails, with soft spotted or clouded fur; the underside of the metatarsus has a long narrow bare line of skin extending up to the heel, in this differing from Viverra; perineal glands round the anus present, but no pouch for storing up their secretion; five toes to each foot, provided with partially retractile claws.

Skull with an elongated bulla, constricted in the middle and divided into two chambers by a septum; dentition i. $\frac{3}{3}$, c. $\frac{1}{1}, \mathrm{pm}$. $\frac{4}{4}, \mathrm{~m} \cdot \frac{2}{2}=40$, all the teeth sharp pointed and compressed; the upper carnassial with an internal lobe, the lower with a considerable talon.

The species of this genus are sadly in need of revision, and there is considerable confusion as to their number. Trouessart, in his catalogue recognises six, and of these four are found in our region; of the others, one (G. vulgaris) is South European and North African, the other ( $G$. pardina) is tropical African.

\section{Key of the South African Species.}

A. Dorsal stripe and body spots black.

a. Spots large, in three rows; tail tip black;

third upper premolar with no internal cusp G. tigrina, p. 53. 
b. Spots small in five or six rows, tail tip white; third upper premolar with an internal cusp

$B$. Dorsal stripe black, spots rusty red

G. felina, p. 55 .

$C$. Dorsal stripe and spots rusty red

G. senegalensis, p. 57.

G. rubiginosa, p. 58 .

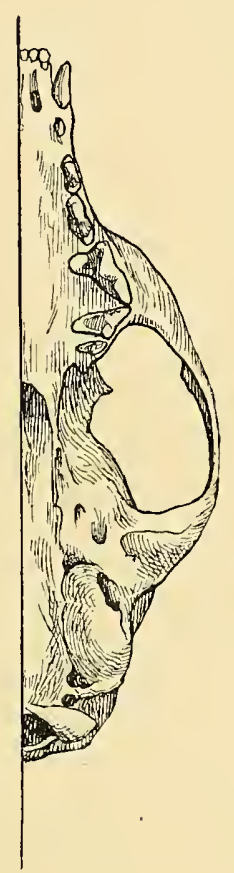

FIG. 12.-Gennetta tigrina, left half of palate ( $\frac{4}{5}$ nat. size).

\section{Genetta tignina. The Large-spotted Genet.}

Viverra tigrina, Schreber, Saügeth. iii, p. 425 pl. cxv (1778); Thunberg, Mem. Acad. Peters. iii, p. 306 (1811); Smuts, Enum. Mamm. Cap. p. 17 (1832).

Genetta tigrina, A. Smith, S. Afr. Quart. Journ. ii, p. 94 (1834); Layard, Cat. Mamm. S. Afr. Mus. p. 33 (1861) ; Lydekker, Handb. Carnivora i, p. 219, pl. xxviii (1895).

Vernacular Names.-Also applied to other species of the genus; Muskkat or Misselyat-kat of Colonists; Inywagi of Amaxosa (Stanford); Insimba of Swazis and Zulus (Kirby); Tshipa of Basutos (Kirby). 
Description.-General colour grey, with a tinge of yellow owing to the extreme tips of the longer hairs being black, under fur slaty; a black dorsal stripe slightly crested posteriorly from just behind the shoulders to the root of the tail; nape of the neck and shoulders with several ill-defined stripes and markings, sides of the body with black somewhat square spots, the larger more than an inch in diameter, arranged in about three longitudinal rows; head tawny grey with a white spot below the anterior part of each eye and also over the front of each lip, the two spots separated by a black patch whence spring the whisker bristles which are partly black and

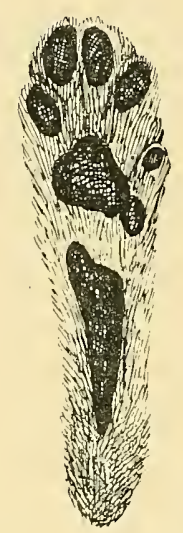

FIG. 13.- Sole of the hind foot of Genetta tigrina.

white; lower lips and chin black, throat whitish; ears rounded, thinly covered with white hairs, a few longer ones at the base posteriorly; fore limbs from above the elbow joint downwards black with a few whitish longer hairs, toes paler; hind limbs below the knee joint almost black; soles with a narrow naked line extending three quarters of the way back to the heel (fig. 13); tail long, a little less than the length of the head and body, clothed with long hair, and bearing about twelve alternately black and dirty-white rings, the black ones slightly broader.

Skull long and narrow, the third upper premolar with no trace of the internal cusp present in G. felina in the skull examined (fig. 12, p. 53).

This species differs from $G$. felina in its darker limbs, larger squarish spots and black tipped tail with predominating black rings, 
and also in the character of the third upper premolar, if this be constant.

Dimensions.-From a mounted specimen in the South African Museum; head and body 22.5 ; tail 17.5 ; hind foot 3.5 ; from ear opening to tip of snout 3.65 ; skull, length 3.60 ; breadth 1.85 ; upper cheek teeth $1 \cdot 55$.

Distribution.-This genet is apparently fairly common throughout the Colony, the Museum possesses several examples from the neighbourhood of Cape Town, where, however, it is not so abundant as the allied small-spotted form; there is also in the Museum a skin from Pondoland in the extreme east. Beyond the Colony it has been recorded from Matabeleland, Nyasaland, Kilima-njaro, Abyssinia and Somaliland.

Habits.-This animal was first made known by a live specimen sent by the Cape Governor, Tulbagh, in 1759 to Holland, where it lived for some time in the menagerie of the Stattholder, and was described by Vosmaer under the name of the Bizamkat; on this description Schreber founded his Viverra tigrina.

The animal is nocturnal in its habits, remaining concealed during the day in thick grass and bushes, or oftener lying extended along the horizontal branch of a tree; its food consists of small game, and it is a great poultry robber; in disposition it is bloodthirsty, fierce and untameable, though, when attacked by dogs, it is considered to be cowardly, not defending itself but only hissing and emitting an evil-smelling yellow secretion from the glands opening in the neighbourhood of the anus.

\section{Genetta felina. The Shald-spotted Genet.}

Viverra felina, Thunberg, K. Velens. Akad. Handl. Stockholm, xxxii, p. 166, pl. vii (1811); Smuts, Enum. Mamm. Cap. p. 18 (1832).

Viverra genetta, apud A. Smith, Descr. Cat. S. Afr. Mus. p. 18 (1826). Genetta felina, A. Smith, S. Afr. Quart. Journ. ii, p. 95 (1834); Layard, Cat. Mamm. S. Afr. Mus. p. 33 (1861).

Vernacular Names.-The names applied to the large-spotted genet apply equally to this species.

Description.-General colour whitish grey, with the tips of some of the longer hairs black, under-fur slaty; dorsal stripe black, extending from the shoulder to the base of the tail, slightly crested posteriorly; sides of the body covered with a much larger number 


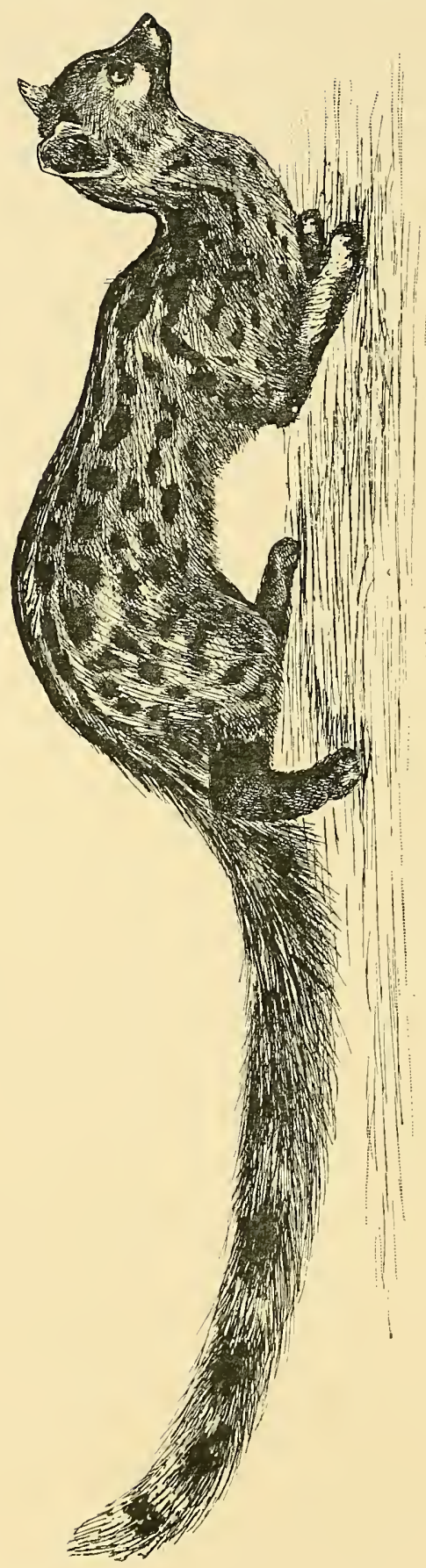

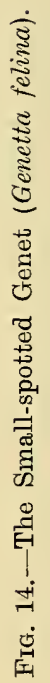


of smaller black spots than in G. tigrina, arranged in about five irregular longitudinal rows, the largest not more than three quarters of an inch in diameter; head markings and ears as in $G$. tigrina; fore-limbs black below, but above the same colour as the back with almost white toes; hind limbs as in G. tigrina, but toes white; tail with about thirteen or fourteen alternate rings of black and white, the black rings being narrower than the white; tip of the tail white.

Skull long and narrow, a little larger but otherwise hardly differing from that of $G$. tigrina; the third upper premolar with a distinct internal cusp and root.

Dimensions.-From a mounted specimen; head and body 23.50; tail 17.50; hind foot 3.0 ; head from ear opening to the tip of the nose 3.25 ; skull, length 3.80 , breadth 1.90 ; upper cheek teeth $1 \cdot 70$.

Distribution.-This species appears to be rather commoner round Cape Town than the former one, and the South African Museum possesses several examples from the neighbourhood; it also occurs at Graaff Reinet and Kuruman and has been recorded by M. Barboza de Bocage from Angola; whether it extends further north it is impossible to say until a thorough revision of the species of this genus has been undertaken.

Habits.-All that was said about the habits of the largespotted genet may equally apply to this species, since the distinction between the two is hardly recognised in the Colony.

\section{Genetta senegalensis. The Senegal Genet.}

Viverra senegalensis, Fischer, Synopsis Mamm. p. 170 (1829).

Genetta senegalensis, Gray, Proc. Zool. Soc. 1832, p. 63 ; id. Cat. Carn. Mamm. B. M., p. 50 (1869); Noack, Zool. Jahrb. iv, p. 169, pl. iv, figs. 30, 32 (1889) [Kalahari].

Description.-General colour whitish grey as in G. felina, the spots on the sides of the body also have much the same distribution as in that species, but are a rusty brown instead of black and contrast strongly with the well-marked crested dorsal stripe which is black; head markings, limbs, and tail as in G. felina.

The skull, judging from the description of Gray and the figure of Noack, resembles that of $G$. tigrina in not having the internal cusp on the third upper premolar. 
The specimen in the South African Museum, from which the description is drawn up, agrees very well with that of Gray above quoted. The species, however, was founded on a figure of the "Genette de Senegal" in F. Cuvier's Mammifères, and this certainly has the spots black, not red, so that it is probable that Gray's species and that of Cuvier are not identical.

Dimensions.-From a mounted specimen in the South African Museum; head and body 20.50 ; tail 18.00 ; hind foot 2.60 ; from ear opening to tip of nose $3 \cdot 10$; skull [apud Gray] length 3.2 ; breadth $1 \cdot 8$.

Distribution.-The South African Museum possesses an example of this species from the Lake Ngami district, obtained by Chapman; and Noack has recorded it from the Kalahari; thence its range extends northwards through Angola to West Africa.

\section{Genetta rubiginosa. The Rusty-spotted Genet.}

Genetta rubiginosa, Pucheran, Rev. Zool. (2) vii, p. 154 (1855) ; Bocage, Jorn. Sci. Lisb. (2) i, p. 177 (1890).

Description.-General colour greyish-white with a red tinge, the limbs of the same colour, and only showing a few small black or blackish spots; the dorsal stripe and spots on the body of a brilliant brick-red, except those of the lowest row, which are blackish; tail somewhat elongated, having as a rule, towards the base four red rings, followed by four or five black ones, which alternate with narrower rings of white with a tinge of red; a considerable space at the tip of the tail formed by a coalescence of two or three black rings.

The description is translated from that of Bocage, and agrees very well with specimens from Bechuanaland, now in the South African Museum.

Dimensions.-From Bocage; head and body 18.90; tail 18.90; from ear to tip of nose $3 \cdot 0$.

Distribution.-This species was originally obtained from Cape Colony by M. Verreaux, and has since been recorded from Angola by M. de Bocage.

It is often to be found in karosses or skin rugs made in Bechuanaland, where it is probably common. There are two flat skins obviously prepared for this purpose in the South African Museum. 


\section{Genus HERPESTES.}

Ichneumon, Lacépede, Mém. de l'Inst. iii, p. 492

(1801) [nec Linn] .................................. ichneumon.

Herpestes, Illiger, Prodr. Syst. Mamm. p. 135

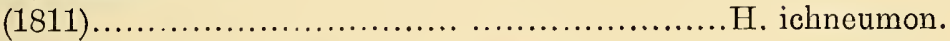

Atilax, F. Cuvier, Hist. Nat. Mamm. iii, livr. 54

(1826)

H. galera.

Animals with long slender bodies and with very short wide ears hardly projecting beyond the surrounding fur; a narrow naked groove always present from the nose to the upper lip; legs somewhat short; body covered with a grizzled fur caused by the individual
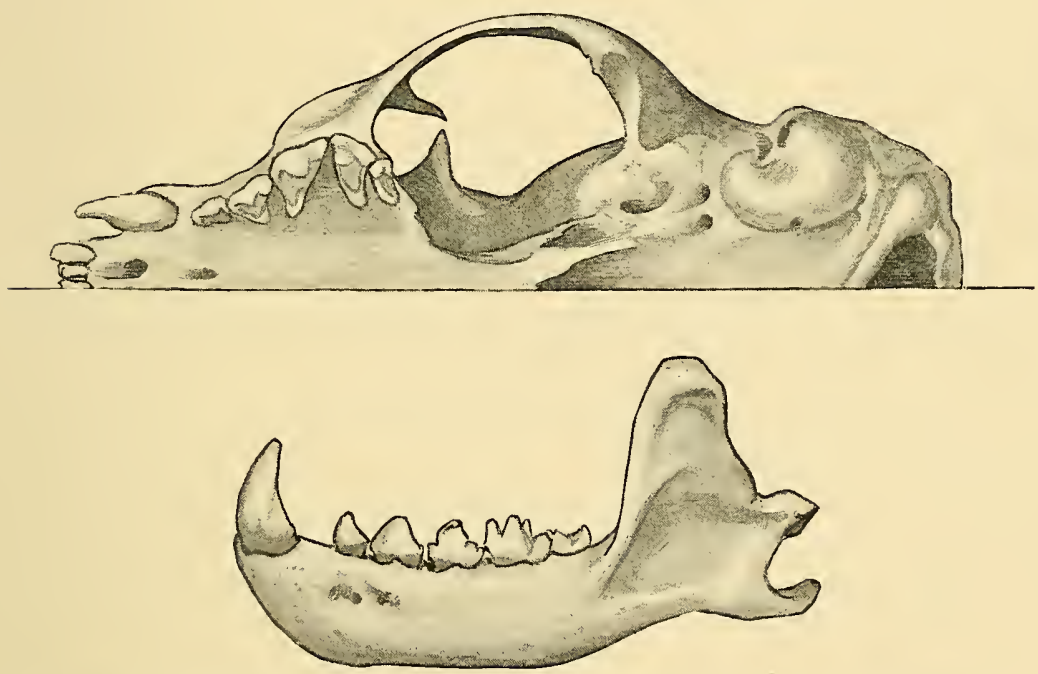

FIG. 15.-Left half of palate and lower jaw of Herpestes galera ( $\frac{2}{3}$ nat. size).

hairs being ringed with two distinct colours; tail at least half as long as the head and body; tarsus sometimes naked, sometimes hairy beneath; five toes to fore and hind feet, the first very short and with a very small claw. Skull long and narrow, considerably contracted behind the post-orbital process, bony orbits complete or nearly so, palate long. Teeth, i. $\frac{3}{3}, \mathrm{c} \frac{1}{1}, \mathrm{pm} . \frac{3 \text { to }}{3 \text { to } \frac{4}{4}}, \mathrm{~m} . \frac{2}{2}=36$ to 40 ; 
the dimensions of the teeth very constant, but the number of premolars varies, even within the limits of a single species.

This is a large genus and contains nineteen species according to Trouessart's Catalogue, distributed over Africa (except Madagascar), Southern Spain and Southern Asia as far as the Malay Peninsula and Borneo. Six are found within our limits.

The present account is founded on an excellent revision of the African species of the genus, published by Thomas (Proc. Zool. Soc. 1882, p. 59).

\section{Key of the South African Species.}

$A$. Tarsus nearly or quite naked below ; posterior upper molar about half the size of its anterior fellow; only two cusps to the posterior lower molar.

a. Tail distinctly black tipped.

$a^{1}$. Large, head and body more than 20 in. H. caffer, p. 60.

$b^{\text {I }}$. Small, head and body less than 15 in. $a^{2}$. Fur grizzled

H. gracilis typicus. p. 62 .

$b^{2}$. Fur bright rufous

H. gracilis badius, p. 62.

b. Tail not black tipped.

$c^{\mathrm{l}}$. Large, head and body more than $20 \mathrm{in.}$, dark rufous...............................

$d$. Medium, head and body 14 to 15 in. grizzled

$e^{1}$. Small, head and body 10 to 13 in., pale grizzled

H. galera. p. 63.

H. pulverulentus, p. 65.

H. punctatissimus, p. 66.

$B$. Tarsus always hairy beneath; posterior upper molar about $\frac{3}{4}$ the length of its anterior fellow.

$f^{\mathrm{I}}$. Skull larger, over 4 in., lower posterior molar with 4 external cusps...........

$g^{1}$. Skull smaller, less than 4 in., lower posterior molar with 3 external cusps, tail usually white

H. grandis, p. 67.

H. albicauda, p. 66.

\section{Herpestes caffer. The Large Grey Mungoose.}

Viverra cafra, Gmelin, Limn. Syst. Nat. i, p. 85 (1789).

Viverra grisea, Thunberg, Mem. Acad. Petersb. iii, p. 305 (1811).

Herpestes griseus, apud Smuts, Enum. Mamm. Cap. p. 19 (1832).

Ichneumon caffer et madagascarensis, A. Smith, S. Afr. Quart. Journ. ii, p. 114 (1834).

Herpestes bennettii, Gray, Charlesw. Mag. N. H. i, p. 578 (1837). 
Herpestes ichneumon, apud Grill, K. Vetens. Akad. Handl. Stockholm ii, 2, p. 14 (1858); Layard, Cat. Mamm. S. Afr. Mus. p. 33 (1861) [nec Linn.]

Herpestes caffer, Thomas, Proc. Zool. Soc. 1882, p. 66.

Vernacular Names. - Grijse Muishond and Kommetje-gat-kat of Colonists; Umvuzi of Amaxosa (Stanford); Mvunti of Swazis (Kirby).

Description.-General colour speckly grey; the fur is coarse and is quite short on the head, but gets longer towards the hinder end of the body, where it reaches a length of nearly four inches; each hair bears up to twelve black and white alternate rings; face in front of the eyes black; ears very short and broad, hardly showing above the fur; limbs getting darker towards the toes, which are almost black; underside of the tarsus usually naked, sometimes though rarely the posterior part hairy; tail tapering, with shorter hairs towards the tip, which latter is provided with a brush of quite black, long hairs, extending beyond the bony tip of the tail a distance of from four to five inches. Skull slender and somewhat narrower than that of $H$. galera, breadth nearly always a little over half the length; a small anterior premolar in the lower jaw, making four in all.

Dimensions.-From a mounted specimen; head and body 26.0 ; tail 18.0; hind foot 3.50 ; from ear to tip of nose 4.0 ; skull (apud Thomas), length 4.3 ; breadth $2 \cdot 14$; upper cheek teeth $1 \cdot 3$.

Distribution.-This mungoose is found all over Africa south of the Sahara, though apparently nowhere abundant; in North Africa and Spain it is represented by an allied species, the true ichneumon, a sacred animal of the ancient Egyptians. In South Africa the large grey mungoose, though widely spread, appears to be nowhere common; there are examples in the South African Museum, from the Cape and Stellenbosch divisions in the west, and from Pondoland in the east, and it is also found in Natal.

Habits.-Little has been recorded of the habits of this animal; it is said to be found in rocky places, and to feed upon mice, small birds and perhaps frogs.

\section{Herpestes gracilis.}

This species is found throughout the whole of the Ethiopian region, and in consequence of its great colour variation has been divided into four sub-species by Thomas; of these two are described below, the others are :- 
(1) H. gracilis melamurus from West Africa, with dark rufous annulated fur.

(2) H. gracilis ochraceus from Abyssinia, with light sandy-yellow annulated fur.

\section{2a. H. gracilis typicus. The Slender Mungoose.}

Herpestes gracilis, Rüppell, N. Wirb. Abyss. p. 29, pl. viii, fig. 2 (1835); Thomas, Proc. Zool. Soc. 1882, p. 68; Bocage, Jom. Sci. Lisbon (2) i, p. 178 (1890).

Herpestes mutgigella, Rüppell, N. Wirb. Abyss, p. 29, pl. ix, fig. 1 (1835).

Herpestes punctulatus, Gray, Proc. Zool. Soc. 1849, p. 11 [Port Natal].

Herpestes ornatus, Peters, Reise Mozamb. Sä̈geth. p. 117, pl. xxvi (1852).

Description.-Form small and slender, general colour yellowish or greyish brown, fur short and annulated, with alternate black and whitish to reddish brown rings; below and extremities somewhat paler, the black rings not being so marked; the tarsus somewhat hairy, the naked portion as a rule occupying the distal two-thirds only; tail nearly as long as the head and body, coloured like the back, with a very strongly marked black tail brush, the hairs of which project one or two inches beyond the bony tip.

Skull like that of $H$. caffra, but much smaller; orbits in both the skulls examined completed posteriorly; teeth slender and sharp, only three premolars in the lower jaw.

Distribution.-Africa, south of the Sahara, from Cape Verde to Abyssinia in the north (the type having been obtained by Rüppell near Massowa on the Red Sea) thence southwards through East Africa as far as Natal, and the Eastern part of the Colony; there are examples in the South African Museum from the neighbourhood of Lake Ngami, from Pondoland and from the Weenen district of Natal.

\section{2b. H. gracilis badius. The Ruddy Mungoose.}

Ichneumon ratlamuchi et cauui, A. Smith, App. Report Exped. Explor. S. Africa, p. 42 (1836).

Herpestes badius, A. Smith, Illustr. Zool. S. Afr. Mamm. pl. iv (1838). Herpestes gracilis var. badius, Thomas, Proc. Zool. Soc. 1882, p. 68; Noac7, Zool. Jahrb. iv, p. 182 (1889). 
Description.-General colour bright rufous, without a sign of annulation, tail tip as in the typical sub-species. Iris red; skull also as in the typical sub-species.

Distribution.-This sub-species appears to be found in the drier parts of South Africa; the type was obtained from Old Latakoo in the neighbourhood of Kuruman in Bechuanaland. The form has also been recorded from the Kalahari ; and there is a richly coloured example in the South African Museum from Upington on the Orange River; it is said by Thomas to extend to Zanzibar.

Dimensions. - (Applicable to both sub-species) from a mounted specimen in the South African Museum. Head and body 12.0 ; tail $11 \cdot 0$; hind foot $2 \cdot 1$; from ear to tip of snout $2 \cdot 1$. Skull, length $2 \cdot 70$; breadth $1 \cdot 40$; upper cheek teeth $1 \cdot 07$.

Habits.-This little mungoose lives in dry districts, where there is plenty of brushwood and undergrowth; it is very shy, hiding quickly when discovered. In East Africa it is said to specially affect old ant-hills round which it plays; its food consists apparently chiefly of insects, these were found by Smith in the stomach of his specimens, and by Noack in the mouth of others; it is also said to devour mice, lizards and snakes.

\section{Herpestes galera. The Water Mungoose.}

Mustela galera, Erxleben, Syst. Reg. Anim. i, p. 453 (1777).

Viverra nems et Mustela afra, Kerr, ed. Linn. Syst. Nat. pp. 160, 175 (1792).

Atilax vansire, $F$. Cuvier, Hist. Nat. Mamm. iii, livr. 54 (1826).

Herpestes paludinosus, G. Cuvier, Règne Anim. ed. 2, i, p. 158 (1829); Smuts, Enum. Mamm. Cap. p. 21 (1832); Grill, K. Vetens. Akad. Handl. Stockholm ii, 2, p. 14 (1858); Layard, Cat. Mamm. S. Afr. Mus. p. 34 (1861).

Mangusta urinatrix, A. Smith, Zool. Journ. iv, p. 437 (1829).

Ichneumon urinator, A. Smith, S. Afr. Quart. Journ., ii, p. 115 (1834). Herpestes galera, Thomas, Proc. Zool. Soc. 1882, p. 72 ; Lydekker, Hanab. Carnivora, i, p. 253 (1895).

Vernacular Names.-Zwarte Muishond and Bruin Kommetje-gat-kat of the Colonists ; Ivuzi of Amaxosa (Cloete).

Description.-General form large, stout and thickset, especially about the head and neck; colour above and below dark brown, the hairs not nearly so long as in $H$. caffer, and annulated with alternate 
bands of pale yellow and brown, the latter predominating, these annulations are sometimes obsolete or absent; under-fur thick, woolly and light brown; head the same colour as the back; limbs dark brown, the annulations being absent; tarsus usually bare up to the heel, sometimes the posterior third hairy; tail little over half the length of the head and body, stout and gently tapering, of the same colour as the body, getting a little darker towards the tip, but never with a distinct black tuft. Skull stout and heavy, particularly the lower jaw ; teeth strong; three lower premolars only.

Dimensions.-From a mounted specimen; head and body $24 \cdot 0$; tail 13.0 ; hind foot 3.9 ; from ear to tip of nose $4 \cdot 0$. Skull, length 4.55 ; breadth $2 \cdot 60$; upper cheek teeth 1.80 .

Distribution.-West and South Africa; the form occurring in North-east Africa being distinguished by Thomas as a sub-species on account of its larger size. The present typical variety is found in French Congoland, Angola, Nyasaland and German East Africa, and appears to be common everywhere south of the Zambesi; the South African Museum possesses specimens from the Cape division and from the Zambesi River.

Habits.-This species, known to Buffon as the "Vansire" from the description given by Flacourt (Histoire de la grande isle Madagascar, p. 154, 1661), of a specimen obtained by him in that island, was only subsequently found to be an African and not a Madagascan species.

This mungoose is a thoroughly aquatic animal, at any rate in the Colony, being almost invariably found in marshy places or on the banks of rivers and streams, concealed in rushes. When pursued with dogs it takes to the water, swimming and diving with great ease, and will even remain for a considerable period entirely immersed, with the tip of its nose alone above water, hidden in the weeds in order to escape its enemies. The fresh water crab (Thelphusa), so common everywhere throughout the Colony, is said to constitute the chief article of diet of this animal, but fishes, frogs, and insects all contribute, and the fowl yard when handy is by no means neglected.

From the glands on either side of the anus this animal is able to diffuse a strong odour described as being "sweet sickening." 


\section{Herpestes pulyerulentus. Thẹ Small Grey Mungoose.}

Herpestes caffra, apud A. Smith, Descrip. Cat. S. Afr. Mus. p. 21 (1826) ; Layard, Cat. Mamm. S. Afr. Mus.p. 34 (1861) [nec Gmelin].

Herpestes pulverulentus, Wagner, Munch. Gel. Anzeig. ix, p. 426 (1839); Thomas, Proc. Zool. Soc. 1882, p. 74.

Herpestes apiculatus, Gray, Proc. Zool. Soc. 1864, p. 551.

Vernacular Names.-Grijse Muishond, Neethaar, or Pepper and Salt Cat of the Colonists ; ilitse of Amaxosa (Cloete).

Description.-General colour resembling that of $I$. caffer, a speckly grey, caused by the long hair being banded with alternate rings of black and white; a woolly under-fur dark brown at the

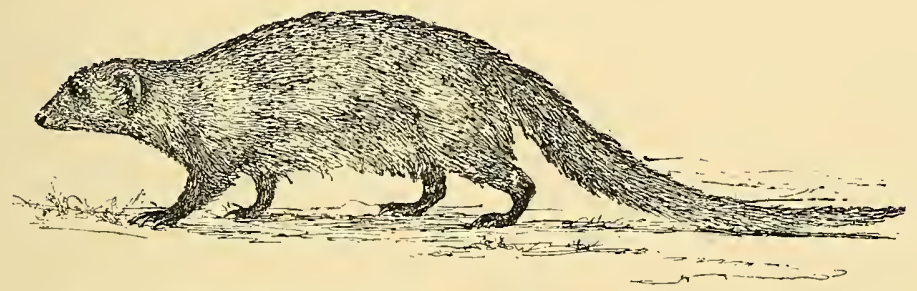

FIG. 16. -The Small Grey Mungoose (Herpestes pulverulentus). (From life.)

base, lighter above; head and extremities slightly darker than the body; naked area of tarsus a narrow band hardly extending to the heel; tail as in $H$. caffer, but without any trace of the black tuft of hair at the tip. Skull resembling that of $H$. gracilis, but somewhat stouter and the teeth rather larger.

Dimensions.-From a mounted specimen; head and body 13.50 ; tail 10.50; hind foot 2.65 ; from ear to tip of nose 2.7 . Skull, length 2.80 ; breadth 1.55 ; upper cheek teeth 1.20 .

Distribution.-This species appears to be fairly abundant throughout the Colony and Natal, but we have no evidence of its extension further north; in the South African Museum there are specimens from the Malmesbury, Stellenbosch, Colesberg, Beaufort West, Griqualand West and East London divisions, while the British Museum contains examples from King Williams Town and Natal.

Habits.-This little mungoose, as I am informed by Mr. Cloete, inhabits dense bush or rocky veld, and is not found as a rule in the open; a favourite resort is an old hollow stump; when pressed 
it will climb trees, especially those with sloping stems, but it is not very active in this respect, and is in no sense an arboreal animal. Its food consists of insects, mice, rats, small birds and their eggs.

\section{Herpestes punctatissimus. The Pale Mungoose.}

Herpestes punctatissimus, Temminck, Esq. Zool. Guin., p. 108 (1853); Thomas, Proc. Zool. Soc. 1882, p. 74.

Description.-General colour pale grey; fur short and harsh, the hairs on the back barely half an inch in length, finely grizzled black and creamy white; below like the back, except the hairs have longer pale tips and less black; tail hairs rather longer than those of the body, uniformly annulated, no trace of the darker tail tip; extremities the same colour as the body; tarsus naked [Thomas]. Skull of the only specimen known imperfect.

This mungoose appears to differ from $H$. pulverulentus, to which it is evidently very closely allied, by its lighter colour and its smaller size.

Dimensions. - Head and body 13.0 ; tail 10.2 ; hind foot 1.75 [Thomas].

Distribution.-The only known example of this species was obtained by Dr. Brehm at Algoa Bay, and is now in the Leyden Museum; there was said to have been a second example in the same Museum from Gaboon, but this is now no longer there.

\section{Herpestes albicauda. The White-tailed Mungoose.}

Herpestes albicaudus, G. Cuvier, Règne Anim. 2nd. ed. i, p. 158 (1829); Thomas, Proc. Zool. Soc. 1882, p. 75.

Herpestes leucurus, Ehrenberg, Symb. Phys. pl. xii, dec. 2 (1832).

Ichneumon albicaudis, A. Smith, S. Afr. Quart. Journ. ii, p. 115 (1834). Ichneumia albescens, I. Geoffr., Mag. Zool. pp. 16, 35 (1839) [descript. not fig.].

Herpestes loumpo, Temminck, Esq. Zool. Guin., p. 93 (1853).

Ichneumia nigricauda Pucheran, Rev. et Mag. Zool. vii, p. 394 (1855).

Description.-Of large size with a somewhat slender body; general colour grey; a very thick woolly under-fur, light slaty at the base, dirty white at the tip, covers the body, beyond which project sparse, long coarse hairs, chiefly black, though some have a 
white ring; the head is the same colour, but with a slight tinge of rufous on the snout and a black ring round the eye, the hair being much shorter and closer; extremities black from the elbow and the hock joints respectively; tarsus completely hairy to the root of the toes; tail a little shorter than the body without the head, of the same colour as the back at the base, but the white hairs gradually predominating so that the last two-thirds of the tail are completely white. In some specimens, especially those from West Africa, the bases of the tail hairs only are white and the tips black, so that the animal appears to have a black tail; such examples have been obtained occasionally in Natal.

Skull stout and heavy, brain case short, teeth rounded, posterior molars above and below larger than in $H$. caffer ; the lower anterior molar with five cusps instead of four.

Dimensions.-Head and body 22.50 ; tail 16.0 ; hind foot 4.45 ; from ear to tip of snout 3.40 ; skull (apud Thomas) length 3.80 ; breadth 2.07 .

Distribution.-The greater part of Africa, from Guinea in the west and Nubia in the east to the eastern part of the Colony, extending into Arabia as far as Muscat. In South Africa it is abundant in Natal and westward as far as the midland districts of the Colony and northwards to Matabeleland; the South African Museum contains specimens from the Albany division of the Colony and from Estcourt in Natal.

\section{Herpestes grandis. The Giant Mungoose.}

Herpestes grandis, Thomas, Proc. Zool. Soc. 1889, p. 622, pl. Ixii. (skull and dentition).

Description.-Only known from a skeleton, the external characters cannot therefore be described.

Allied to $H$. albicanda, from which it differs in being larger, and in the form and dimensions of the teeth; in H. grandis the canines are longer above by $2 \mathrm{~mm}$., below by $3 \mathrm{~mm}$., than in the other species; in the posterior lower molar there are two anterointernal cusps instead of one and the single median external cusp present in $H$. albicauda is doubled; furthermore the posterior edge or talon of the same tooth, which is simple in $H$. albicauda, is regularly crenulated in this species; in consequence of these complications the whole tooth is practically the same size as its neigh- 
bour in front, the anterior molar, whereas in $H$. albicanda it is only about 86 per cent. of the latter.

Dimensions.--Length of skull, from incisors to condyle 4.50; breadth $2 \cdot 5$.

Distribution.-The type, a skeleton now in the British Museum, was obtained by Mr. T. E. Buckley, either on the Limpopo River or in Zululand. No other specimen is known.

\section{Genus HELOGALE.}

Helogale, Gray, Proc. Zool. Soc. 1861, p. 308............... Ty. parvula.

Slender auimals with elongated bodies and short legs, with a naked line between the nose and upper lip, with five toes to each foot and a naked tarsus; the characters by which the genus is separated from Herpestes are: (a) the shape of the skull, which is shorter, broader and smoother; $(b)$ the number of the teeth, which is always 36 , i.e., i. $\frac{3}{3}$, c. $\frac{1}{1}, \mathrm{pm} . \frac{3}{3}, \mathrm{~m} . \frac{2}{2}=36$; the premolars are constantly three in number, and there is no diastema or interval between the anterior premolar and the canine, as in those species of Herpestes which have only three premolars. In addition to the single species mentioned below, two others from East Africa and Somaliland respectively, are described, but they do not seem to be worthy of being considered as anything more than sub-species or geographical races.

\section{Helogale paryula. Wahlberg's Mungoose}

Hespestes parvula, Sundevall, Oefvers. Akad. Forh. Stockholm, iii, p. 121 (1847) [Natal, Wahlberg].

Helogale parvula, Gray, Proc. Zool. Soc. 1861, p. 308 [figs. of skull] ; Thomas, Proc. Zool. Soc. 1882, p. 79 ; Jentink, Notes Leyd. Mus. xi, p. 31 (1889); Bocage, Jorn. Sci. Lisbon (2) i, p. 180 (1890) [habits in Angola].

Description.-Small and slender; general colour above and below dark, finely grizzled grey-brown, the hairs annulated with black or brown and yellowish white; extremities a little darker; tail shorter and rather darker than the body; no trace of rufous on any part of the body [Thomas]. The characters of the skull are given under the genus.

The geographical sub-species replacing this one further north in 
tropical Africa is distinguished by its greater size and by its bright rufous throat and belly.

Dimensions.-Head and body 9.5 ; tail 5.5 ; hind foot 1.5 ; skull, length from condyle 1.82 ; breadth 1.13 [Thomas].

Distribution.-Natal, extending northwards to Mozambique, where it merges with a geographical race, Helogale parvula undulata, which extends northwards along the east coast to Kilimanjaro, beyond which a third geographical race, $H$. parvula attinsoni takes its place as far as Somaliland; the typical subspecies is also recorded from Angola. An example from the Waterberg district of the Transvaal is in the Pretoria Museum, but it is not represented in the South African Museum.

Habits.--This species seems to be a rare one, as except for the record of its occurrence in Angola by M. B. de Bocage, it is only known from the original specimens collected by Wahlberg many years ago, and from the example recently obtained in the Transvaal.

M. de Anchieta writes to M. de Bocage regarding this little mungoose that it inhabits both cultivated and uncultivated lands; that it is social in its habits, often joining forces to attack snakes; it lives in holes in trees or underground, or in deserted termite's nests, and plays havoc in poultry-yards.

Mr. R. D. McHawker (Proc. Zool. Soc. 1898, p. 764) gives a good account of the habits of the allied species, $H$. atkinsoni, in Somaliland.

He states that they hunt in packs of about fifteen individuals, and that they take refuge in a deserted termite's nest or among a heap of stones; that their food consists, judging from their droppings, of locusts and other insects, and that they become very tame and make delightful pets.

\section{Genus RHYNCHOGALE.}

Rhinogale, Gray Proc. Zool. Soc. 1864, p. 573 [nec Gloger, 1842]

Type.

Rhynchogale, Thomas, Proc. Zool. Soc. 1894, p. 139... R. melleri.

This genus agrees in most of its characters with Herpestes; the toes are five in number on both fore and hind feet, and the tarsus is hairy; it differs, however, from the typical genus in having no naked line running from the nose to the upper lip; the skull has a 

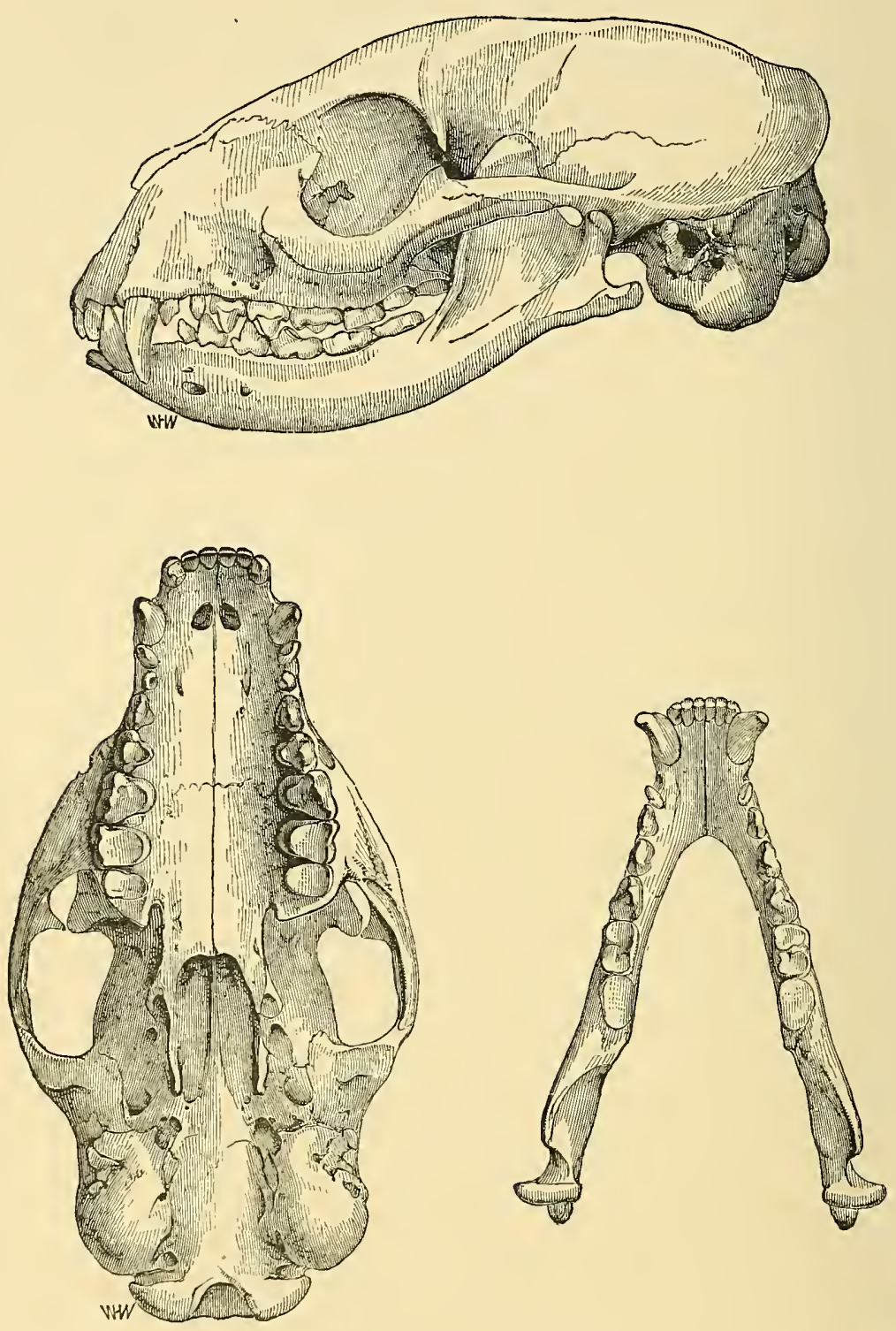

Fig. 17.-Skull of Rhynchogale melleri (from Gray, Proc. Zool. Soc.). 
rounded form without any marked angles or crests, and the palate is deeply concave both transversely and longitudinally, a character which separates it from all other mungooses; dentition i. $-\frac{3}{3}$, c. $\frac{1}{1}$, pm. $\frac{4}{4}, \mathrm{~m} . \frac{2}{2}=40$; exceptionally as in the type of the species as described by Thomas there are five upper premolars.

This genus contains only the single species described below.

\section{Rhynchogale melleri. Melder's Mungoose.}

Rhinogale melleri, Gray, Proc. Zool. Soc. 1864, p. 575 [figs. of skull, \&c.] ; Thomas, Proc. Zool. Soc. 1882, p. 85, pl. iii. [animal].

Rhynchogale melleri, Thomas, Proc. Zool. Soc., 1894, p. 139.

Description.-Fur harsh and rough ; form resembling that of $H$. albicauda, general colour dark-ashy, darker along the middle line of the back, woolly under-fur dark slaty, with pale brown tips, longer hairs ringed brown and white; head coloured like the body, nose completely surrounded by hair, so that there is no bare line between the nose and the upper lip; extremities the same colour as the body, or a little darker; tarsus hairy to the toes; tail with long hairs much as in $H$. albicauda, with a dark dorsal line and black tip, all the hairs being white at the base ; iris dark brown with sea green centre.

Skull and teeth described above in the generic diagnosis.

Dimensions. - Of the type specimen from Thomas; head and body 22.0 ; tail 15.5 ; hind foot 3.8 ; of a young specimen in the South African Museum measured in the flesh, head and body 17.50; tail 13.50; height at shoulder 7.50 ; skull of type from Thomas, length $3 \cdot 38$; breadth $1 \cdot 85$.

Distribution.-The type obtained by Dr. Meller, now in the British Museum, probably came from the Lower Zambesi; since then the British Museum has received specimens from Nyasaland; in the South African Museum is a young example from Komatipoort on the Pretoria-Delagoa Bay railway, presented by Mr. H. F. Francis, which brings the species well within the South African limits.

Habits.-Mr. A. Whyte, who collected the Nyasaland specimens, found wild fruits within the stomachs of those examined. 


\section{Genus CROSSARCHUS.}

Crossarchus, F. Cuvier, Hist. Nat. Mamm. ii. livr.

This genus resembles the preceding one in haring no naked line from the nose to the upper lip, and in having five toes to each foot, but on the other hand, it has a naked tarsus.

The skull resembles that of Herpestes, but the vacuity in the floor of the bulla is usually in adult skulls filled up, leaving a row of small holes.

Dentition-i. $\frac{3}{3}$, c. $\frac{1}{1}$, pm. $\frac{3}{3}, \mathrm{~m} . \frac{2}{2}=36$ : teeth somewhat rounded without sharp cutting edges; the posterior lower molar with an extra cusp in the middle of the outer edge as in $H$. albicauda.

This genus is confined to Africa; in addition to the one species described below, some four or five others are known from West, Central, and North-eastern Africa.

\section{Crossarchus fasciatus. The Banded Mungoose.}

Viverra ichneumon B, Schreber, Säugeth. iii, p. 430, pl. cxvi, (1778).

Herpestes fasciatus, Desmarest, Dict. Sci. Nat. xxix, p. 58 (1823).

Ichneumon taenionotus, A. Smith, S. Afr. Quart. Journ. ii, p. 114 (1834) [Natal].

Crossarchus fasciatus, Thomas, Proc. Zool. Soc. 1882, p. 90 ; Pousargues, N. Arch. Mus. Paris (3) vi, p. 123 (1894); Matschie, Säugeth. Deutsch-Ost-Afrikas, p. 81, fig. 47 (1895).

Description.-Of medium size; general colour grizzled grey, on the hinder half of the body a series of about twenty alternate black and dirty-white bands, the posterior part of each white band shading gradually through rufous into the black; these bands are caused by the regular manner in which the individual hairs are arranged, so that all the light and dark rings come together; belly and head of the same colour as the anterior part of the back; no bare line between the nose and upper lip; limbs becoming a little darker, almost black, towards their extremities; five toes to each foot; tarsus bare to the heel; tail about half the length of the head and body, and of the same colour as the latter, getting black towards the tip.

Dimensions. - Of a mounted specimen in the South African Museum: head and body 16.0 ; tail 7.5 ; hind foot 2.35 ; from ear 
opening to nose tip 2.40 ; skull, length 2.77 , breadth 1.52 ; upper cheek teeth $\cdot 75$.

Distribution.-The banded mungoose is found throughout Eastern and South-eastern Africa from Kilima-njaro southwards throughout Nyasaland to the Transvaal, Natal and Kaffraria; in Natal it is the common mungoose of the coast lands. The South African Museum contains examples from near Lake Ngami, the Waterberg district of the Transvaal, and from near Durban.

Habits.-A good account of this animal by Bohm is given in Matschie's work. He says that they are usually found near rivers, and live in small social communities, often in old ant-heaps; they generally sit up on their haunches like the meerkat, and, in fact, closely resemble it in every respect; their voice consists of twitterings, trillings and pipings, when pleased, but when angry they growl and bark sornething like a dog ; they live on insects, for which they diligently scratch the ground, also on fruits and seeds, which latter can always be found in their excrement; eggs and snails they break by picking them up in their fore paws and dashing them down between their hind feet against a stone or a wall; they are further said to sprinkle their food with urine before eating it. This mungoose is frequently seen in captivity, especially in Zanzibar; it makes a docile and amusing pet, and is said to be most useful in ridding a house of cockroaches and other insect pests. It is eaten with relish by the Wagalla, a tribe in German East Africa.

\section{Genus CYNICTIS.}

Cynictis, Ogilby, Proc. Zool. Soc. 1833, p. 48

Type.

This genus contains animals of the same general character as Herpestes, but without a naked line from the nose to the lip; there are five toes to the fore feet, but only four to the hind; the tarsus is quite hairy; the skull resembles that of Herpestes especially $H$. gracilis and the teeth are forty in number, i.e., i. $\frac{3}{3}$, c. $\frac{1}{1}, \mathrm{pm} . \frac{4}{4}, \mathrm{~m} . \frac{2}{2}$. The only two authenticated species are confined to South Africa.

\section{Key of the Species.}

a. Breadth of the skull exceeds the length of the palate by at least a quarter of an inch

C. penicillata, p. 74 .

$b$. Breadth of skull about equal to the length of the palate C. selousi, p. 75 . 


\section{Cynictis penicillata. The Bushy-tailed Megrkat.}

Herpestes penicillatus, G. Cuvier, Règ. Anim. ed. 2, i, p. 158 (1829);

Smuts, Enum. Mamm. Cap. p. 20 (1832).

Mangusta levaillantii, A. Smith, Zool. Journ. iv, p. 437 (1829).

Cynictis steedmani, Ogilby, Proc. Zool. Soc. 1833, p. 49.

Cynictis typicus, A. Smith, S. Afr. Quart. Journ. ii, p. 116 (1834).

Cynictis ogilbyii, A. Smith, S. Afr. Quart. Journ. ii, p. 117 (1834); id,

Illustr. Zool. S. Afr. Mamm. pl. xvi (1839); Layard, Cat. Mamm.

S. Afr. Mus. p. 34 (1861).

Cynictis lepturus, A. Smith, Illustr. S. Afr. Zool. Mamm. pl. xvii (1839).

Cynictis penicillata, Thomas, Proc. Zool. Soc. 1882, p. 83 ; Noack,

Zool. Jahrb. iv, p. 185 pl. iv, figs. 39, 43 (1889) ; Haagner, Zoologist (4), iii, p. 179 (1899).

Literature.-Steedman (1835), ii, p. 296, description and habits with figure; Farini (1886) p. 463, habits in the Kalahari.

Vernacular Names.-Geel or Rooi Meerkat of Colonists; Igala of Amaxosa (Cloete).

Description.-General colour yellowish brown to pale yellowish grey; hair on the body soft and short, fur slaty at the base, then light yellow, the tips of the longer hairs ringed brown and white, below paler almost white; head like the back; chin and throat white; ears dark brown posteriorly but with white hairs along the margin; limbs somewhat pale, claws very dark, five to fore, four to hind limbs; tarsus hairy behind the toe pads; tail about as long as the body without the head, covered with long thickset hairs giving it a somewhat distichous, bushy appearance, tail hairs yellow at the base and tip with a broad black band between; tail tip usually wbite ; iris of eye bright red. Skull resembling that of $H$. gracilis but a little larger with a more inflated bulla, having a vacuity in its floor; lower jaw with four premolars.

Dimensions.-From a mounted specimen ; head and body 15.5 ; tail 9.0 ; hind foot 2.80 ; from ear opening to tip of nose 2.90 ; skull length 3.65 ; breadth 1.45 ; upper cheek teeth $1 \cdot 10$.

Distribution.-Chiefly found in the drier parts of the eastern half of the Colony extending eastwards to Tembuland and King Williamstown, northwards through the Free State, the high veld of the Transvaal, Bechuanaland and the Kalahari to Lake Ngami, but apparently replaced in the western Karoo by the other Meerkat (Suricata tetradactyla); there are examples in the South African Museum from Graaff Reinet, Potchefstroom, and the neighbourhood of Lake Ngami. 
Habits.-These animals are found in the dry barren Karoo plains and never in bushveld; they associate in colonies of twenty individuals upwards, forming burrows in mounds where the earth is loose, and sometimes inhabiting the deserted earths of the springhaas (Pedetes caffer); at the mouth of these burrows they are frequently to be seen seated on their haunches and looking around for any sign of danger, whereat they disappear with great rapidity down into the ground.

They are diurnal in habits and wander forth in the daytime in search of food; their pace is described as a walk, but when excited or frightened they move along in a series of bounds clearing the ground very quickly.

Their food consists of rats, mice, small birds and insects. When near a farm they will devour eggs and young chickens, they are also said to be particularly partial to the eggs of the large leopard tortoise (Testudo pardatis) which they dig up, guided, it is said, by the strong smell of the urinary excretion, dropped by the tortoise when burying its eggs.

This meerkat is said to be very savage when captured, but when subdued by hunger, becomes much more docile, though always treacherous and apt to bite; it never seems to become quite so tame as the true meerkat (Suricata tetradactyla).

\section{Cynictis selousi. Selous' Meerhat.}

Cynictis selousi, de Winton, Ann. Mag. N. H. (6) xviii, p. 469 (1896).

Description.--This species is only known from the skull, which differs from that of $C$. penicillata in being much broader and more rounded; the squamosal part of the zygoma is not so expanded laterally, and is only bowed up slightly; the ascending process of the malar bone is very slender, barely meeting the post-orbital process; the auditory bullae are considerably inflated, and the breadth of the skull is nearly equal to the length of the palate, whereas in C. penicillata it exceeds it by $\cdot 25$ at all ages.

Dimensions.-Of skull, length $3 \cdot 0$; breadth $1 \cdot 70$.

Distribution.-The type and only specimen known is a skull, and was obtained by Mr. Selous at Essex Vale, near Bulawayo, and is now in the British Museum. 


\section{Genus SURICATA.}

Suricata, Desmarest, Tabl. Meth. Mamm. in Nouv. Dict.

Type.

d'Hist. Nat. ed. 1, xxiv, p. 15 (1804) .............. S. tetradactyla. Rhyzaena, Illiger, Prodr. Syst. Mamm. p. 134 (1811) S. tetradactyla.

Mungoose-like animals with no naked line from the nose to the upper lip, with a slender snout projecting far beyond the lips; with four toes on both fore and hind limbs; claws of fore limbs exceedingly long, double those of the hind limbs; tarsus naked; skull quite different in general shape to that of the other mungooses,

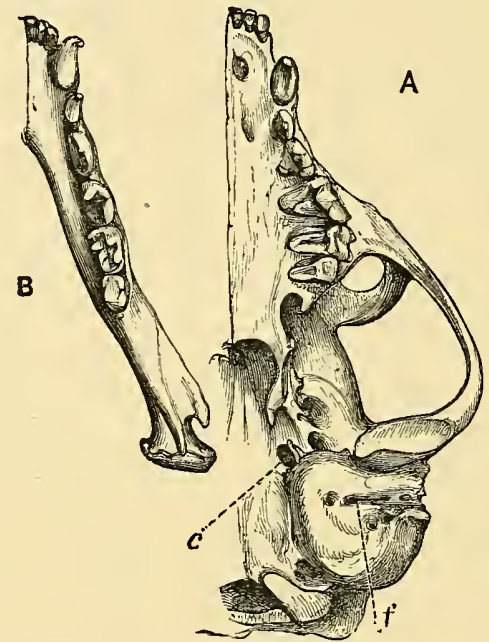

FIG. 18.-A, left half of palate; B, lower jaw of Suricata tetradactyla; $c$, carotid foramen; $f$, fissure in the floor of the auditory bulla (after Mivart).

being short and broad, the zygomatic arches widely diverging outwards from in front; the auditory bullae are flattened, the meatus somewhat prolonged, with a fissure or line of fine holes marking its course. Dentition i. $\frac{3}{3}$, c. $\frac{1}{1}, \mathrm{pm} . \frac{3}{3 \cdot 4}, \mathrm{~m} . \frac{2}{2}=36$ to 38 . Only the single species mentioned below is described; it is confined to South Africa.

\section{Suricata tetradactyla. The Slender-tailed Meeriat.}

Viverra suricatta, Erxleben, Syst. Regn. An. p. 488 (1777).

Viverra tetradactyla, Schreber, Säugeth. iii, p. 434, pl. cxvii (1778); Thunberg, Mem. Acad. Peters. iii, p. 305 (1811). 
Mus zenik, Scopoli, Delic. Flor. et Faun. ii, p. 84 (1786).

Suricata capensis, Desmarest, N. Dict. d'Hist. Nat. ed. 1, xxiv, p. 15 (1804).

Surikata viverrina, Desmarest, N. Dict. d'Hist. Nat. ed. 2, xxxii, p. 297 (1819).

Ryzaena surakatta, A. Smith, Descrip. Cat. S. Afr. Mus. p. 32 (1826).

Rhyzaena capensis, Smuts, Enum. Mamm. Cap. p. 22 (1832).

Rhyzaena typicus, A. Smith, S. Afr. Quart. Journ. ii, p. 117 (1834).

Suricata zenick, Layard, Cat. Mamm. S. Afr. Mus. p. 35 (1861).

Suricata tetradactyla, Thomas, Proc. Zool. Soc. 1882, p. 92 ; Noack, Zool. Jahrb. iv, p. 188, pl. v, fig. 44-6 [skull] (1889) [Kalahari]; Lydekker, Handb. Carnivora i, p. 276 (1895).

Literature.-Holub (1882), p. 142, on its habits ; Martin (1890), p. 157, account of habits in captivity.

Vernacular Names.-Meerkat of Colonists.

Description.-Form small and slender; general colour grizzled grey, under-fur woolly, pale brown; the whole back is irregularly transversely marked with alternate black and white bands, caused by the regular arrangement of the black and white rings on the longer hairs; below pale yellowish; head grizzled grey, a black patch round the eye ; snout projecting considerably beyond the lips and surrounded by hair, ears very low, but conspicuous by the deep black of the skin and hairs on their anterior surface ; tail short and slender, about half the length of the head and body, becoming reddish yellow towards the tip, of which the extreme $1 \frac{1}{2}$ inches is black.

Skull and teeth described above in the generic diagnosis.

Dimensions.-From a mounted specimen ; head and body 14.5 ; tail 7.0 ; hind foot 2.35 ; ear opening to tip of nose 2.60 ; skull, length 2.57 ; breadth 1.45 ; upper cheek teeth 1.1 .

Distribution.-This meerkat seems to be a somewhat more westerly form than the bushy-tailed meerkat, it is found in all the upland divisions of the Colony from Namaqualand and Ceres in the west, as far as Griqualand East in the east, and northwards throughout the Orange Free State and Great Namaqualand. In the South African Museum are examples from the Namaqualand and Woodhouse divisions of the Colony.

Habits. - This species is first mentioned by Buffon, who possessed an example purchased in Holland, which he believed to have come from Surinam in South America; this error was corrected by Schreber, who saw an example in the menagerie of the Staatholder of Holland, and who showed that the name "suricate" was 
wrongly applied to this animal, and that it really belonged to a lemur from Madagascar. In habits this species closely resembles the bushy-tailed meerkat, living in small colonies in burrows on the Karoo. Its voice is described by Buffon as resembling a policeman's rattle when it is pleased, and the bark of a young dog

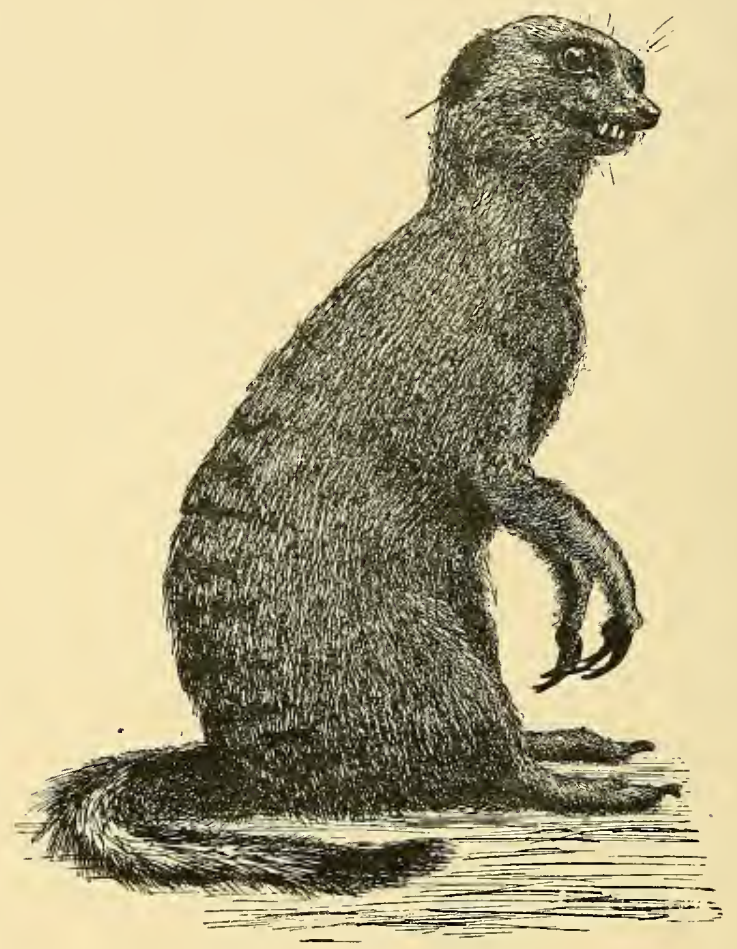

FIG. 19.-Suricata tetradactyla.

when annoyed. Its food consists of small animals, and particularly of insects and their grubs, which it digs up with unerring dexterity; in captivity meat, fish, and eggs are relished. Two young ones are usually born at a time; it is extremely tame and docile in captivity, more so than the bushy-tailed form, and is very commonly kept as a pet throughout the country. 


\section{Family PROTELIDAE.}

\section{Genus. PROTELES.}

\section{Type.}

Proteles, Is. Geoffr. Mem. du Museum, xi, p. 355 (1824)...P. cristatus.

General form hyaena-like, but fore feet with five toes, of which the pollex is much shorter than the others, hind feet with only four toes ; the claws are not retractile, and the animal is digitigrade.
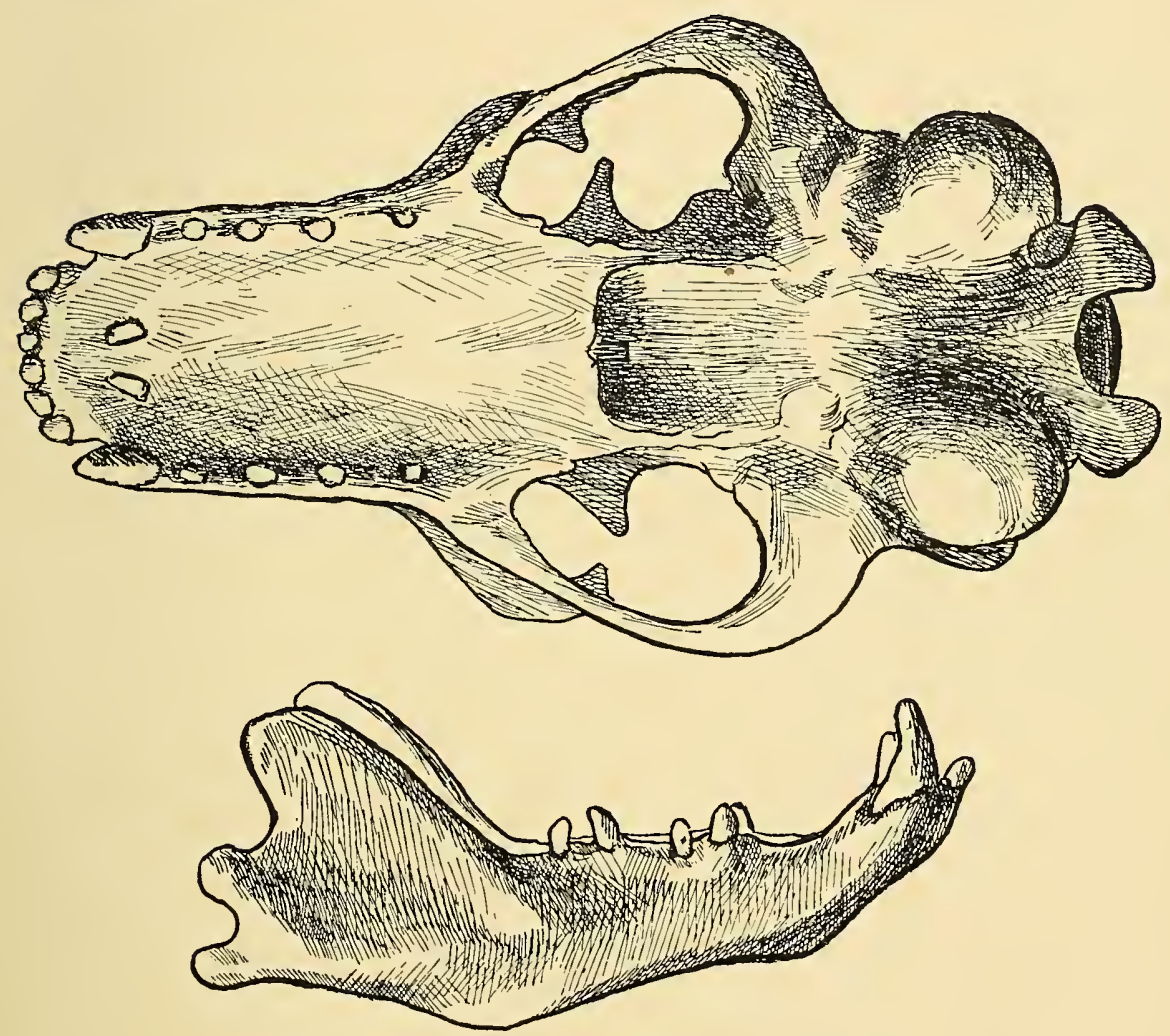

FIG. 20.-Palate and lower jaw of Proteles cristatus showing the rudimentary molars.

The skull has no alisphenoid canal, and the auditory bulla is divided into two chambers.

Dentition.-i. $\frac{2}{8}$, c. $\frac{1}{1}$, pm. $\frac{3}{3}, \mathrm{~m} . \frac{1}{1},=32$; the incisors and 
canines are normal in shape and size, but the molars are very small, almost rudimentary and set very far apart in the jaw, so that they cannot be of the slightest use to the animal as far as mastication is concerned.

The species described below is the only representative of the family and the genus, and has long been a puzzle to naturalists; it has relationships to both the Hyaenidae and the Viverridae, but on the whole most authors are agreed to place it in a special family by itself.

\section{Proteles cristatus. The Aard Wolf.}

Viverra cristata, Sparrman, Resa till Goda Hopps-udden (1783); id. English Translation, (Dublin ed. in 8vo) ii, p. 192 (1785).

Viverra hyaenoides, Desmarest, Mamm. p. 538 (1820).

Proteles lalandii; Is. Geoffr., Mem. du Museum xi, p. 371 pl. xx (1824); Simuts, Enum. Manm. Cap.p. 23 (1832).

Proteles typicus, A. Smith, S. Afr. Quart. Journ. ii, p. 96 (1834).

Proteles cristatus, Layard, Cat. Mamm. S. Afr. Mus. p. 35 (1862); Flower, Proc. Zool. Soc. 1869, p. 474, pl. xxxvi [animal].

Literature.-Steedman (1835) ii, p. 114, description and affinities; Nicolls and Eglington (1892), p. 92, description, distribution, and habits; Bryden (1893), p. 59, occurrence in Bechuanaland; Kirby (1896) p. 554, native names and habits in Eastern Transvaal ; Schönland, Zoologist (4), i. (1897), p. 155, habits; Bryden (1899a) range and habits; Hobson, Cape Agricultural Journal xv. (1899), p. 351, habits and depredations.

Vernacular Names.-Grey Jackal apud Sparman; Nadrou Jackal apud Smith; Aard Wolf or Maanhaar (i.e., Mane-hair) Jackal of the Colonists; Inci of Amaxosa (Stanford) ; Isingci of Swazis, Taku of Basutos (Kirby).

Description.-Form hyaena-like but smaller; general colour dirty yellowish grey, under-fur thick and woolly, with dark slaty basal, and yellowish white apical halves through which project a number of longer coarser hairs, partly white, partly black and white; along the line of the back from the nape to the tail these hairs are much more numerous, from seven to eight inches in length, and form a regular black crest, erectile at the will of the animal. On the shoulders two or three horizontal, and on the body five or six transverse black stripes ; beneath lighter, no black; head dark grey, with short hairs only; face in front of the eyes brown and nearly bare of hair, lower jaws and chin also brown; ears rather narrow and pointed, about three inches long, thinly covered with white 
hairs in front and brown behind; legs with indistinct black bands above, becoming black below the knees and hocks; five toes and claws (the first falling far short of the others) to the fore feet, four only to the hind; completely digitigrade; tail short, half the length of the body, very bushy, yellowish at the base, apical three quarters black, composed of long coarse hairs white at the base, followed by an indistinct darker ring, then a white ring, the terminal quarter being black

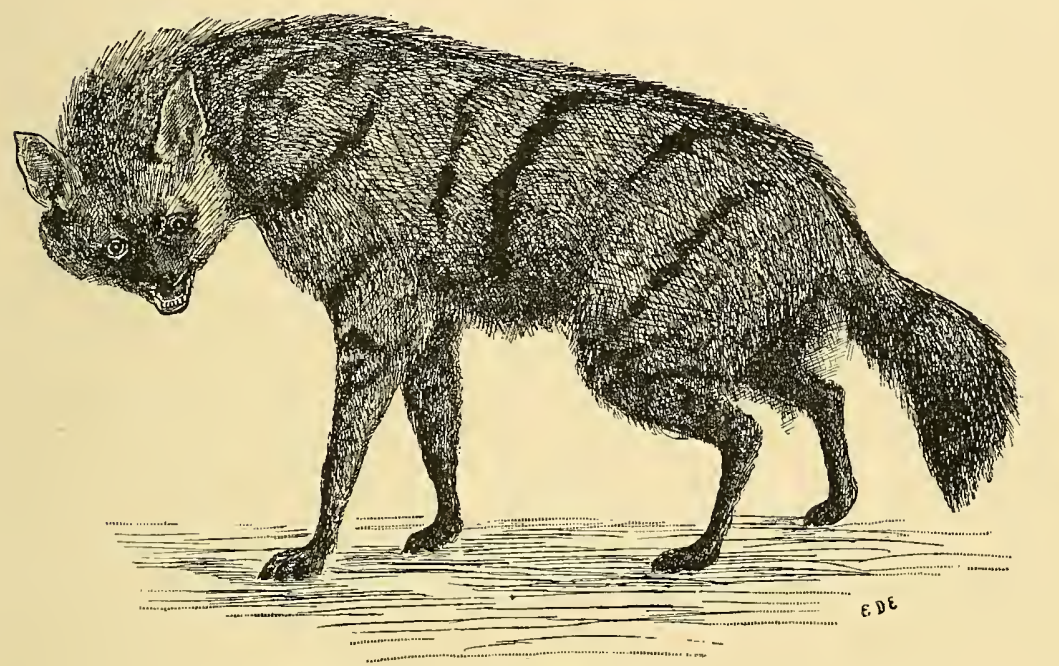

FIG. 21.-Proteles cristatus.

In the female the woolly hair is less rufous, and the general colour is somewhat lighter.

Skull and dentition as described above.

Dimensions.-From a mounted specimen : head and body $32 \cdot 0$; tail without terminal hairs $6 \cdot 0$, with 10.50 ; hind foot 5.50 ; from ear opening to tip of snout $5 \cdot 50$; skull length 5.55 ; breadth 3.40 ; upper cheek teeth $2 \cdot 25$.

Distribution.-The aard wolf is found from Somaliland through Central Africa to the Colony, but does not appear to occur in Nyasaland or in the German territories to the east, or in West Africa.

In South Africa it is not uncommon throughout the Colony and 
Natal, though seldom seen; it is also abundant in German Southwest Africa, in Bechuanaland, the Orange Free State, the Transvaal, and the western portion of Matabeleland.

The South African Museum posesses examples from Stellenbosch and Beaufort West, from Potchefstrom in the Transvaal, and from Maritzburg in Natal.

Habits.-The aard wolf was first described by Sparrman, the celebrated Swedish traveller, who obtained a specimen near the little Fish River, in what is now the Somerset East division of the Colony. He stated that the animal was known to the farmers as the grey jackal, and gave a very recognisable description of it, though he unfortunately lost the specimen subsequently.

A few years later the French traveller and collector Delalande, obtained specimens from near Algoa Bay, which M. Is. Geoffroy St. Hilaire named after the collector.

The aard wolf is found both in open treeless and in bushy veld; it is purely nocturnal in its habits, passing the day in burrows and holes, or sometimes lying out in thick bush.

The earths are sometimes constructed by the animals themselves, but more often they make use of those of the aard-vark (Orycteropus).

It is a slow animal and can be run down by an active man, and is easily outpaced by dogs.

The question of the food of the aard wolf is one that has given rise to considerable discussion; Sparrman and other authors who have examined the stomachs of these animals, found that they contain nothing but termites or white ants ; this is further confirmed by Mr. Cloete, who writes that he has examined the stomachs of more than fifty, and never found any trace of anything else than a purely insectivorous diet, ants being the chief constituent. He further examined the excrement of these animals for traces of any other than insectivorous diet, but without result. These researches are fully confirmed by the extraordinary rudimentary condition of the molar teeth, which would certainly prevent the animal from dealing with any bony matter.

Notwithstanding this, it is constantly reported by farmers that young sheep and kids are carried off by the aard wolf, and that they will also devour carrion and ostrich eggs.

Other farmers state that they do not devour kids and lambs, but kill them merely for the sake of the milk contained in their stomachs, much in the same way as the baboons, which appear also 
to have only recently acquired these destructive habits. Of this latter fact there can be little or no doubt, as it is confirmed by many farmers whose observations are above suspicion, but I still consider that it is very doubtful whether they ever actually carry off and devour the bodies of their victims.

Mr. Cloete informs me that he has found that from two to four young ones are produced at a birth.

The aard wolf when attacked discharges a yellow viscous fluid from the glands on either side of the anus, which has a musky smell characteristic of the animal.

Most observers describe the aard wolf as a cowardly and timid animal ; Mr. Cloete combats this statement, saying, that though not wishing for one moment to class it with such desperately pugnacious animals as the otter, ratel, or bush-pig, at the same time, compared with such animals as the black-backed jackal, it is a perfect paragon of courage. It is cornmonly hunted with fox terriers and affords good sport, making a kind of roar, ending in a yell as it charges the dogs.

\section{Family HYAENIDAE.}

\section{Genus HYAENA.}

Hyaena, Zimmermann, Spec. Zool. Geogr. p. 365 (1777). H. Hype.

Carnivorous animals with the front limbs longer than the hind; digitigrade with four toes to each foot, all supplied with strong non-retractile claws; tail short, less than half the length of the body; opening above the anus under the tail is a median glandular sac which receives the secretion of the scent glands lying on either side of the rectum.

Skull with incomplete orbits, and strong sagittal crest for the attachment of the powerful jaw muscles; the auditory bulla is not divided into two chambers, and there is no alisphenoid canal.

Dentition, i. $\frac{3}{3}$, c. $\frac{1}{1}, \mathrm{pm} . \frac{4}{3}, \mathrm{~m} \cdot \frac{1}{1}=34$; upper carnassial with a blade of three lobes and an anterior internal cusp, upper molar very small, and often deciduous, especially in the spotted species, and transversely placed; lower carnassial with a two-lobed blade and small posterior talon, all the teeth large and strong.

This genus is the only one of the family, and contains in addition to the two South African species a third, the striped 

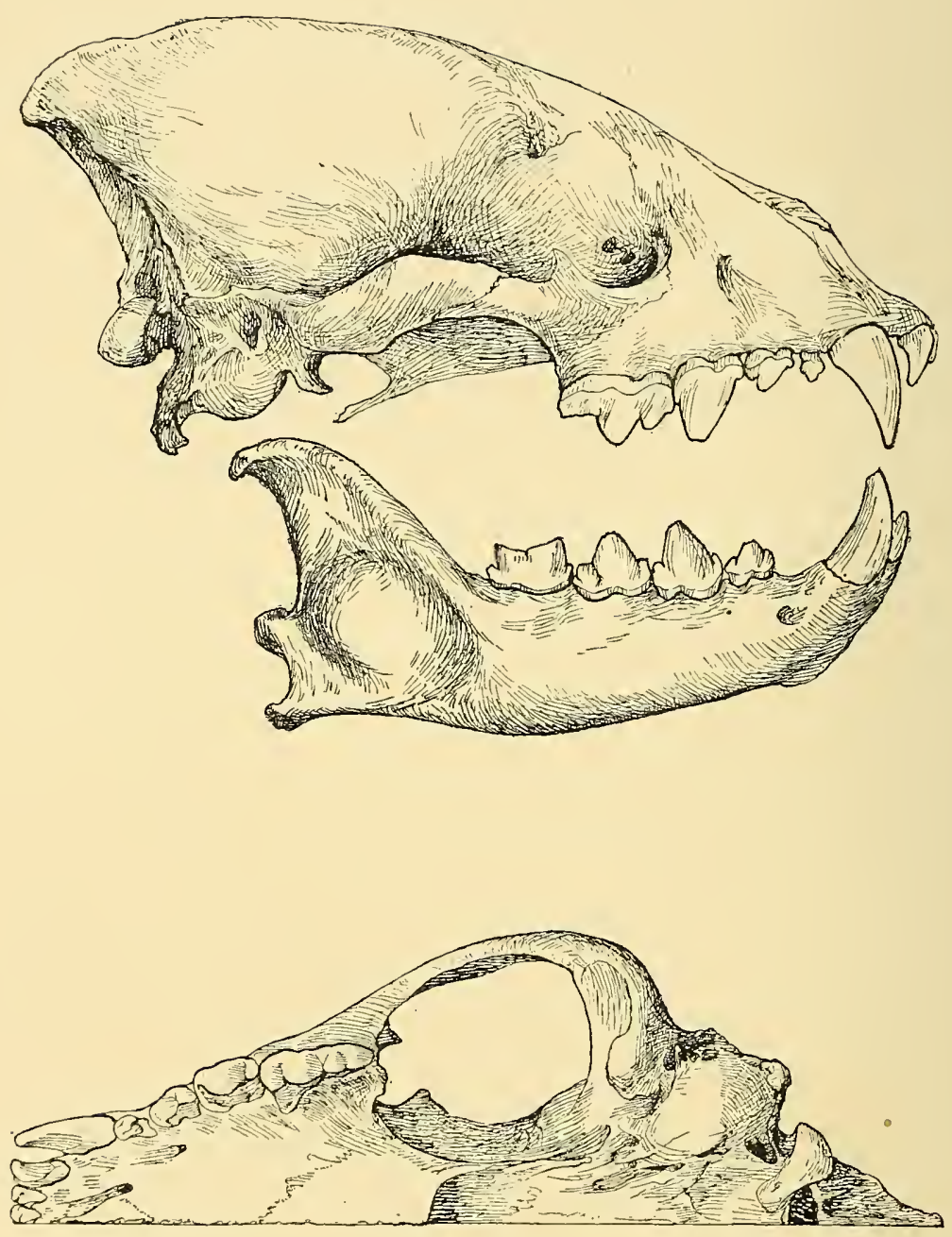

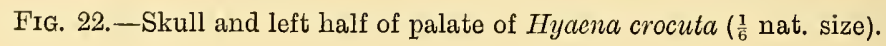


hyaena (Hyaena striata) of Southern Asia and Northern Africa. From the tertiary beds of Europe and India, too, a large number of extinct forms allied to all the three existing species have been described.

\section{Key of the South African Species.}

a. General colour brown, unspotted, with long hair and pointed ears ........................................

b. General colour fulvous, spotted darker, hair short and ears rounded.

H. brunnea p. 85.

H. crocuta, p. 87.

\section{Hyaena brunnea. The Brown Hyaena or Strand Wolf.}

Hyaena brunnea, Thunberg, K. Vetensk. Akad. Handl. Stockholm, p. 59, pl. i. (1820); Murie, Trans. Zool. Soc. vii, p. 503, pl. lxiii. (1871) [anatomy].

Hyaena fusca, E. Geoffr., Dict. Class. Hist. Nat. viii, p. 444, pl. cxlviii, fig. 2 (1825); Smuts, Enum. Mamm. Cap. p. 24 (1832); A. Smith, S. Afr. Quart. Journ. ii, p. 119 (1834).

Hyaena striata, apud A. Smith, Descr. Cat. S. Afr. Mus. p. 14 (1826) (nec Zimmermann).

Hyaena villosa, A. Smith, Trans. Linn. Soc. xv, p. 461, pl. xix. (1827); Layard, Cat. Mamm. S. Afr. Mus. p. 36 (1861).

Literature.-Sparman (1785) i, p. 175, describes a specimen which he wrongly identifies with the striped Hyaena; Moodie (1835) i, p. 249, account of habits; Steedman (1835) ii, p. 111, describes and figures under name of Hyaena villosa with account of its habits and occurrence in central districts away from sea: Harris (1840), figured on plate xxx.; Delagorgue (1847) i, p. 46, describes its habits of scavenging along the seashore in search of fish and crustacea in the Piquetberg division; Cumming (1855), i, p. 167, met this animal in Griqualand West; Nicolls and Eglington (1892), p. 92, range, habits and description; Bryden (1899a), p. 596, range and habits.

Vernacular Names.-Strand Jut or Strand Wolf of the Colonists; Incuka of Amaxosa (Stanford).

Description. - Form hyaena-like, with hind quarters falling away, broad head and very thick neck; general colour ashy-brown, the body covered with very long coarse hairs, reaching on the posterior part of the back a length of nearly 10 inches; no woolly under-fur; head of the same colour as the body but with short, close hair, with darker almost black cheeks, chin and throat; a narrow bare line connects the nose and the upper lip; ears large 
and pointed, about $5 \frac{1}{2}$ inches long, very scantily covered with hair; behind the ears a light-coloured, almost white collar encircles the neck, the chest and belly also lighter; limbs with imperfect dark brown bands, with four toes in front and behind; tail short, about a quarter the length of the body, covered with long coarse hairs like the back.

Skull narrower, and more pointed than that of the spotted hyaena; in the skull examined, an adult, but not an old one, the

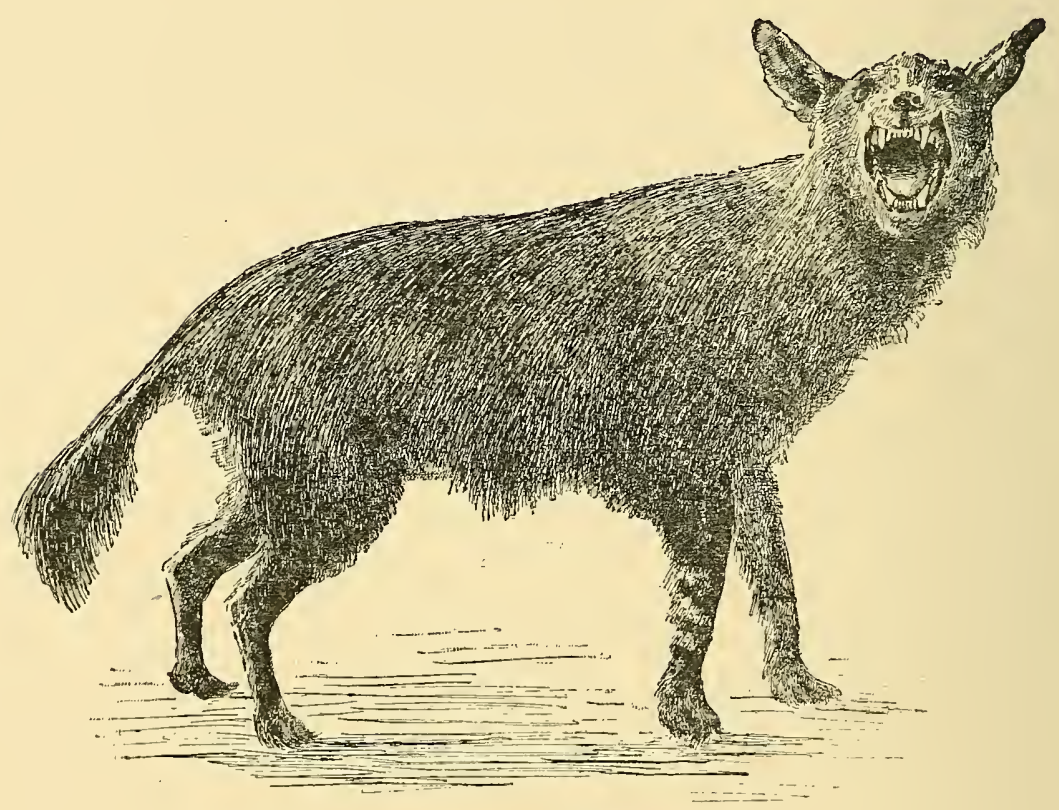

FIG. 23.-Hyaena brunnea.

premaxillae and frontals do not meet, being separated by the nasals and maxillae; the reverse is the case in the spotted form; the teeth in this species are not quite so large and strong, but the posterior upper molar is much larger and three-rooted, whereas in the spotted hyaena it is very small and usually deciduous, the lower carnassial molar, though considerably smaller, resembles that of the other species in not possessing any trace of an inner cusp.

Dimensions.-From a mounted female; head and body $3 \mathrm{ft.} 10$; 
tail without hairs, $7 \cdot 0$; with hairs 12.0 ; hind foot 9.0 ; from ear opening to tip of nose, 9.5 ; skull, length 9.0 ; breadth, 6.50 ; upper cheek teeth $4 \cdot 75$.

Distribution.-The strand wolf seems to be confined to southwest Africa, and not to extend north of the Zambesi ; in the Colony it was formerly abundant especially along the sea coast, it has now from persistent poisoning and trapping become very rare; it never seems to have extended far to the east or to have reached Natal; in German South West Africa, the Kalahari, and western Matabeleland it is said to be still fairly common, and I have also heard of its occurrence in the Waterberg district in the north-west Transvaal. There are specimens in the South African Museum obtained some years ago from Groenekloof in the Malmesbury division, and from the Nieuveld near Beaufort West, and one, a female, has quite recently been acquired from the Fish River Bush near Grahamstown.

Habits.-As is the case with so many South African animals, little has been recorded about the habits of this species ; it was at one time supposed that it was found only along the coast but this is now known to be by no means true.

Like its spotted cousin this species is nocturnal in its wanderings, remaining concealed during the daytime; those which have their home along the coast are said to be ichthyophagous, feeding on dead fish, crabs and an occasional stranded whale, but they are certainly also a danger to the sheep and cattle kraals, in fact the specimen in the South African Museum from Groenekloof is said to have killed three of Mr. Van Reenan's calves before it was finally destroyed. Sir A. Smith had a live specimen for some time, and gives a good general account of its habits in captivity. He describes it as a timid and cunning animal; he further states that it is the general belief in the Colony that they regurgitate, for the benefit of their young, a portion of the food which they themselves have swallowed, and that he observed that they occasionally did bring up their food again and chew it afresh.

\section{Hyaena crocuta. The Spotted Hyaena or Tiger Wolf.}

Canis crocuta, Erxleben, Syst. Regn. Anim. p. 578 (1777).

Hyaena maculata, Thunberg, Mem. Acad. Petersb. iii, p. 302 (1811) ; Smuts, Enum. Mamm. Cap. p. 24 (1832); A. Smith, S. Afr. Quart. Journ. ii, p. 119 (1834). 
Hyaena capensis, Desmarest, Mamm. p. 216 (1820).

Hyaena crocuta, A. Smith, Descr. Cat. S. Afr. Mus. p. 12 (1826); Watson, Proc. Zool. - $S o c .1877$, p. 369 pls. xl, xli; id. ibid. 1878, p. 416 , pls. xxiv, xxv ; 1879 , p. 79 pls. v, vi ; 1881, p. 516 pl. xlix [complete account of anatomy especially of urinogenital organs].

Crocuta maculata, Layard, Cat. Mamm. S. Afr. Mus. p. 36 (1862).

Literature.--Kolben (1731) ii, p. 108; a quaint account of the "Tyger Wolf"; Sparrman (1785), i, p. 167, observations on this animal in the Caledon division; Lichtenstein (1812), ii, p. 15, notes on the habits of an individual caught in the neighbourhood of Cape Town in 1804; Steedman (1835), p. 198, and Moodie (1835), p. 249, observations on habits; Harris (1840), figured on pl. xxx, fig. 1; Grout (1863), p. 292, habits in Natal; Drummond (1875), p. 307, account of in Zululand; Nicolls and Eglington (1892), p. 90, range, description and habits; Kirby (1896) p. 554 names, habits, and occurrence in the Eastern Transvaal; Kirby (1899) p. 323, distribution in Mozambique; Kirby (1899a) p. 592, range and habits.

Vernacular Names.-Tyger Wolf, or simply Wolf of the Colonists; Isadawane of Amaxosa (Stanford); Impisi of Swazis, Zulus, and Matabeles (Drummond and Kirby); Kwiri of Basutos (Kirby).

Description. - Form large and massive in front, falling off towards the hind quarters, which stand about four inches lower; general colour dirty yellow, fur rather woolly with no trace of the longer coarser hairs; along the neck and front part of the back the hairs are rather longer and somewhat forwardly upstanding, forming a species of reversed mane; body, shoulders and haunches covered with irregular circular spots of a dark brown or black colour which vary considerably in arrangement and distinctness; below, chest and belly somewhat paler. Head large, unspotted, rather darker about the muzzle; ears shorter and broader than in the other species, about 4 inches in length; posteriorly covered with tawny hairs, anteriorly with white; lower part of the extremities a little darker than the body; both fore and hind feet with four claws, those of the former considerably larger than those of the latter; tail short, thinly haired at the base, ending in a brush of long black hairs forming the terminal half.

Skull larger, more massive and blunter than the other species; the other distinguishing characters are described above in the account of the brown hyaena.

Dimensions.-From a mounted specimen; head and body 4 ft. 6 ; tail without terminal hairs 9.0 , with 14.0 ; bind foot 9.50 ; from ear opening to nose 9.50 ; skull, length 9.75 ; breadth 7.25 ; upper cheek teeth $5 \cdot 1$. 
Distribution.--The spotted hyaena is found over Africa south of the Sahara from Senegal, Abyssinia, and Somaliland southwards; in the Congo basin, however it has hitherto not been noted, it may perhaps be absent; it was formerly abundant throughout the Colony. Sparrman speaks of it as being extremely common near the Cape Town shambles in his times, but now poisoning and trapping have greatly reduced its numbers, and there are few except in out-of-the-way districts; in Natal there appear to be some few left unexterminated; north of the Orange River the spotted hyaena seems to be found everywhere, and is specially common in Ovampoland and in the Eastern Transvaal and Portuguese territory, both in elevated and low country. In the South African Museum are to be found a skull from Beaufort West, and a mounted skin recently obtained from the Beira district.

This species is now generally identified with the cave hyaena of Europe, the remains of which have been found throughout Europe from Yorkshire to Gibraltar, and as far east as the Madras Presidency in India.

Habits.-Much has been written about the spotted hyaena, and all travellers, without exception, combine to revile it for its cowardice, greed, and cruel treachery. The animal is nocturnal, spending the day in holes (frequently those of aard-vark's (Orycteropus) whence the rightful owners are displaced) and caves, or even in thick bush, and sallying forth at night along well-defined paths stretching in all directions singly, in pairs, or small troops in search of food.

The hyaena soon proclaims its presence by its remarkably powerful voice, which consists of two distinct cries, first a long drawn out mournful note beginning low and ending high, compared by Sparrman to the letters "aauæ," this is the usual cry of the animals to one another; the other cry resembles the laugh of a maniac more than anything else, and is only given vent to under sexual or any other great excitement; it is from the latter cry that this species is sometimes known as the "laughing hyaena." The appetite of the animal is boundless; it is entirely carnivorous, but it seems to prefer putrid and decaying matter, and never kills an animal unless driven thereto by hunger; sheep and donkeys are generally attacked at the belly, and the bowels torn out by the sharp teeth of the marauder, and horses are also a frequent object of attack, but in this case shackling is effective as the horse, unable to escape, faces the hyaena, which incontinently bolts.

This animal is an excellent scavenger, perhaps this may be said 
to be its only good point; it is asserted that it will sometimes hide food in running water for a future occasion, so as to prevent its odour from spreading around.

The hyaena has been known to attack and carry off young children, though the least attempt at pursuit will cause it to drop them ; many stories, too, are told of its assaults on sleeping natives, in this case it invariably goes for the face of the man with its powerful jaws. Drummond states that he has seen many men who had been thus mutilated, some with noses wanting, others with the whole mouth and lips torn away; this is also confirmed by other authors.

Although the hyaena is well endowed with acute senses of scent and hearing and also is exceedingly strong, it is undoubtedly a very cowardly animal, and also very treacherous and cunning; unless absolutely obliged it will never face opposition but will always make off; if possible it always attacks from behind, selecting some weak and dangerous spot. Drummond relates an instance of where no less than seven cows were mortally injured in a single night by two hyaenas, who attacked them in succession, jumping up and seizing the udders and biting them off with their powerful teeth.

The hyaena is so wary that it is difficult to trap or to exterminate it with spring guns, in fact the poisoned meat method seems to be the only really successful plau of getting rid of it.

It was believed by the authors of classical times, and it is still the prevalent notion among the South African Colonists, that the hyaena is hermaphrodite, and a large number of curious stories concerning its reproductive habits are consequently widely spread in South Africa.

These notions have doubtless arisen in consequence of the fact that the external reproductive organs of the female closely resemble those of the male, and without dissection it is exceedingly difficult to distinguish the two sexes from one another.

A full account of these peculiarities, and of the general anatomy of the spotted hyaena, is given in the series of papers by Dr. Watson quoted in the synonymy. 


\title{
Division CYNOIDEA.
}

\author{
Family CANIDAE.
}

The dogs, wolves, jackals, and foxes form a single family and are easily recognised as distinct from the rest of the Carnivora.

The principal characters are a somewhat elongate muzzle, with moderate tail, and well-developed limbs ; feet digitigrade, with four toes to the fore and four or five to the hind feet; in the skull the post-orbital processes are short, so that the eye is never surrounded by a ring of bone, the auditory bulla is inflated but not divided; an alisphenoid canal is present.

There are always four premolars on either side above and below, the upper carnassial bears two cusps, the anterior backwardly-directed one being the larger, the posterior forming a compressed ridge; there is also a small inner lobe at the anterior end of the tooth; the first upper molar is large and broader than it is long, with two cusps on the external border, the second upper molar is similar but smaller; the lower carnassial is also a large tooth with anteriorly a well developed bilobed blade of which the hinder cusp is the larger; on to this latter hangs a small inner tubercle, while the posterior part of the tooth is formed of a well marked tuberculated heel.

The family is almost world-wide in its distribution and is mostly carnivorous in its habits; some of its members are predatory, several hunt in troops, all have very acute senses of smell, sight, and hearing.

A. Toes 4-5.

\section{Key of the South African Genera.}

a. With two molars above and three below.

$a^{1}$. Tail (without terminal hairs) less than half the length of the head and body; post-orbital processes of the skull smooth and convex ............ body; post-orbital processes of the skull concave Vulpes, p. 97.

b. With three to four molars above and four below ... Otocyon, p. 99.

B. Toes 4-4; skull and other characters as in Canis ..... Lycaon, p. 101. 


\section{Genus CANIS.}

Canis, Linnaeus, Syst. Nat. 12th ed., i, p. $56(1766)$...... C. familiaris.

This genus contains the animals usually known as wolves, dogs, and jackals; the number of toes (except in some domestic dogs) is always four on the front and five on the hind feet; the tail has, as a rule, a moderate brush and is less than half the length of the animal ; the pupil is round and there are from eight to ten mammae.

The skull is strong, with a frontal sinus within the frontal bone, and with smooth convex post.orbital processes.

The dentition is as follows-i. $\frac{3}{3}$, c. $\frac{1}{1}$, p.m. $\frac{4}{4}, \mathrm{~m} . \frac{2}{3}=42$; all the teeth are strong and powerful.

This genus contains the greater number of the members of the family and is distributed over almost the whole world.

\section{Key of the South African Species.}

a. Back silvery black, contrasting with the rufoustinged sides. C. mesomelas, p. 92 .

b. Back and sides light silvery grey, a diagonal white side stripe

C. adustus, p. 95 .

\section{Canis mesomelas. The Black-Backed JackaL.}

Canis mesomelas, Schreber, Säugeth. iii, p. 370, pl. xcv. (1778); Thunberg, Mem. Acad. Petersb. iii, p. 302 (1811); A. Smith, Descr. Cat. S. Afr. Mus. p. 11 (1826); Smuts, Enum. Mamm. Cap. p. 16 (1832); A. Smith, S. Afr. Quart. Journ. ii, p. 85 (1834); Layard, Cat. Mamm. S. Afr. Mus. p. 29 (1861) ; Noack, Zool. Jahrb. iv, p. 164 (1889) [Kalahari]; Mivart, Monogr. Canidae, p. 45, pl. xii. (1890); Lorenz, Ann. kk. Hofmus. ix. notizen, p. 66 (1894) [western Transvaal].

Literature.-Kolben (1731) ii p, 125, described under the name of Tenlie or Kenlie; Moodie (1835), p. 357, on its habits; Livingstone (1857), p. 50, mentioned under the name of Pukuye; Hall, Cape Monthly Mag. (1860), p. 286, habits and account of hunting; Grout (1863), p. 292, described as Impunguche; Nicolls and Eglington (1892) p. 94, description, distribution and habits; Bryden (1893), p. 60, common in Bechuanaland; Kirby (1896), p. 555, occurrence in the Eastern Transvaal with vernacular names; Bryden (1897), p. 110, jackal hunting in Bechuanaland with fox hounds; Kirby (1899), p. 324, distribution in Mozambique; Hobson, Cape Agricultural Journal, xv. (1899), p. 351, habits and depredations. 
Vernacular Names.-Jackhals, rooi Jackhals, red, golden or sometimes silver Jackal (which last however is best reserved for V. chama), Fox (near Cape Town where hunted) of Colonists; Pukuye of Bechuanas (Livingstone); Impungutshe of Swazis (Kirby), Amaxosa (Cloete), and Zulus (Grout).

Description.-About the size of a large English fox; general colour of back greyish black, the under-fur woolly and reddish yellow, beyond which project long hairs, black at the base and tip, with a broad white median portion; sides of the body rufous, the line of colour division between the back and sides sharply marked by a black line, below from chin to vent much paler.

Head rufous, the muzzle a purer colour, posteriorly mixed with white hairs; ears fairly large about four inches in length with a few white hairs anteriorly, posteriorly and a patch at their base rufous; limbs of the same colour as the sides; tail about one-third the length of the head and body, bushy like an English fox's brush, composed of long rather woolly hairs, basally greyish yellow, with black tips becoming more developed towards the extremity of the tail, which appears quite black.

The upper molars are smaller than the corresponding teeth in C. adustus, measuring along their outer edge $\cdot 45$ and $\cdot 26$ respectively against .55 and $\cdot 35$; on the other hand the upper carnassial is larger being $\cdot 71$ length against 61 in $C$. adustus; the anterior internal cusp of the same tooth is very small.

Dimensions.-From a mounted specimen in the South African Museum; head and body 39.0 ; tail 14.0 ; hind foot 6.25 ; from ear opening to tip of nose $7 \cdot 50$; skull length $6 \cdot 20$; breadth $3 \cdot 30$; upper cheek teeth $3 \cdot 45$.

Distribution.-This animal is found everywhere abundantly throughout South Africa, and extends northwards through Angola and Central Africa to Somaliland and middle Nubia. It is not recorded from German East Africa, Mozambique, West Africa or French Congo.

Habits.-In the more thickly inhabited parts of the country this jackal is strictly nocturnal in its habits; it cannot, perhaps, be called a social animal, though occasionally in the evening a few may be seen together. Like the English fox, during the daytime, it lies out in the thick bush, but the young are born in an "earth," either excavated by the animal itself or more often constructed by an aard-vark; to this earth, if hard pressed by dogs, the jackal will generally retreat. 
This animal may almost be said to be omnivorous; it is fond of carrion and will kill lambs, kids, hares and fowls when carrion is not available. Mr. Cloete further states that it will break ostrich eggs for the sake of their contents, and that he even once found a water tortoise in the stomach of an individual examined by him.

The usual voice of the jackal is described by $\mathrm{Mr}$. Cloete as a "wailing-laughing" sound; another form of voice is a quacking or cackling sound to which it gives vent when attacked, and finally, especially when young ones are about, a short "wuff" something like the bark of a dreaming dog, but louder, can be heard.

As has already been stated the young are born in holes or earths, and six seem to be the usual number of puppies. Mr. Cloete gives the following account: "The young ones have almost always a 'back door' by which they can escape; this is just large enough for the puppies to squeeze through, whatever their size; as a rule, as soon as the terriers go down the earth in which there are young ones, they fly out through one of these small 'back door' holes through which, as a rule, the terriers are unable to follow, and should there be no one to intercept them on the surface make away into the veld as hard as they can; the parents are very rarely found in the holes with the young ones; they are generally lying in the nearest patch of bush and may often be seen watching the proceedings from a safe distance. The male helps the female in foraging for the little ones, they either carry the food in their mouths or, should they not be able to get a good piece to carry away, eat their fill and then vomit the contents of their stomachs for the young ones to eat."

In disposition the jackal is "most cowardly," again quoting Mr. Cloete, "making no resistance to speak of when caught by a determined dog, yet frequently chasing and biting small curs which it sees are afraid of it." It will seldom attack big sheep. It is very cunning, and difficult to trap, unless very special precautions are taken and will also frequently refuse to take a poisoned bait, but after chewing it slightly will drop it on the ground again and make off.

This is the jackal which is so abundant everywhere all over the Colony, and which is so terribly destructive among the flocks of the stock-farmer. A reward of 7s. $6 \mathrm{~d}$. a tail is paid in the Colony to encourage their destruction, but although very large sums have been expended in this way, but little apparent effect has hitherto been produced. 
On the Cape flats, in the neighbourhood of Cape Town, it has been hunted with foxhounds for a great number of years, and has given very good sport; and in Bechuanaland also there has been from time to time a regular pack of hounds hunting this species, chiefly owing to the energy of Major-General Sir Frederick Carrington; an account of this hunt will be found in Mr. Bryden's book quoted above.

\section{Canis adustus. The Side-striped Jackal.}

? Canis variegatoides, A. Smith, S. Afr. Quart. Journ. ii, p. 87 (1834).

Canis adustus, Sundevall, Oefvers. Akad. Forhandl. Stockholm iii, p. 121 (1847) [Magaliesberg] ; Bocage, Jorn. Sci. Lisb. (2) i, p. 182 (1889); Mivart, Monogr. Canidae, p. 49, pl. xiii (1890); Lorenz, Ann. 7k. Hofmus. ix, notizen, p. 66 (1894); Pousargues, Ann. Sci. Nat. (8) iii, p 278 (1896).

Canis lateralis, P. L. Sclater, Proc. Zool. Soc. 1870, p. 279 pl. xxiii [Gaboon].

Canis holubi, Lorenz, Verh. kk. Zool. bot. Ges. Wien xlv, p. 110 (1896) ; id. Ann. kk. Hofmus. xi, p. 6 (1896); [Pandamatenka and Leshumo Valley, near Victoria Falls.]

Description.-Form rather stout; general colour silvery grey, rather blacker on the back; on either side of the body a more or less distinct diagonal white stripe with a similar black one bordering it below; the hair on the back is long, from 3 to 4 inches, and consists of a rather coarse, pale reddish under-fur beyond which project longer black hairs with a broad white subterminal band; the regular arrangement of the bands on these long hairs causes the side stripe; head speckly grey with a rufous tinge, ears short, about 3 inches long only, posteriorly the same colour as the head anteriorly with a few long white hairs; chin pale brown, contrasting with the rufous brown throat and chest; limbs with a slight rufous brown tinge and traces of a black transverse band above the hocks on the hind legs; tail about half the length of the head and body covered with long hairs, but not so brush-like as in the other species; basal third yellowish, distal two thirds mingled black and yellowish, tip pure white.

The female is considerably lighter in colour, much less rufous and with the side stripes very faintly marked.

The skull is more massive than that of $C$. mesomelas, and the teeth differently proportioned as described above.

Dimensions.-From a mounted male; head and body 29.50; 
tail 14.0 ; with terminal hairs 18.0 ; hind foot 6.50 ; from ear opening to tip of nose 7.50 ; skull, length 6.10 ; breadth 3.5 ; upper cheek teeth $3 \cdot 50$.

Synonymy.-The history of this species is by no means clear as is seen by the four names included in the synonymy; the earliest of these is C. variegatoides of Smith, who, however, in his description does not mention the white tail tip, or the side stripes so characteristic of this species; further he described the colour of the ears as chestnut, which is difficult to reconcile with the present species as generally understood. The plate of Mr. P. L. Sclater's C. lateralis, from Gaboon, agrees with individuals I have examined, except that in it the colour of the ears is represented as a pure rufous brown instead of a speckled grey.

Senhor Barboza de Bocage has compared specimens of sidestriped jackals from Angola and from Gaboon (true C. lateralis), and states that though externally the two forms agreed very well, that the skull of the Angola jackal is larger and somewhat differently shaped from that of Gaboon.

Finally, two examples of a side-striped jackal obtained near the Victoria Falls, by Dr. Holub, were examined by Dr. Lorenz von Liburnau; he at first identified these with Canis adustus, of Sundevall, which he believed to be specifically distinct from $C$. lateralis, but subsequently he came to the conclusion that they represented a third species differing from all those hitherto described in their shorter and thicker heads, their more stumpy noses, and their higher legs.

On the whole I am inclined to identify with one another all the side-striped jackals, including $C$. adustus, which, though always described as coming from Caffraria, was really obtained in the Magaliesberg range near Pretoria, and which was doubtless a female or a young male with an ill-developed stripe.

Distribution.-Central Africa extending to Kilima-njaro and Gaboon in the one direction, and to Angola, the Transvaal and Nyasaland in the other; south of the Zambesi it has been obtained in the Magaliesberg in Western Transvaal and near the Victoria Falls; the South African Museum possesses a pair shot by Mr. Selous close to Bulawayo, and it is probably the common jackal of Rhodesia.

Habits.-To Du Chaillu and Dr. Pechuel-Loesche we are chiefly indebted for accounts of the habits of this jackal; it is stated to hunt in packs and to prey on small mammals, sick individuals of 
larger species, and also to feed on the fruit of the oil palm; it will interbreed with domestic dogs and can be tamed with facility.

\section{Genus YULPES.}

Yulpes, Brisson, Regn. Anim., p. 239 (1756)

Animals of slighter build with a more pointed muzzle, and a tail usually exceeding half the length of the head and body and very bushy; ears large, pupil vertically elliptical, six mammae.

Skull with no frontal sinus, and with the post-orbital processes concave.

Teeth like those of Canis but less powerful.

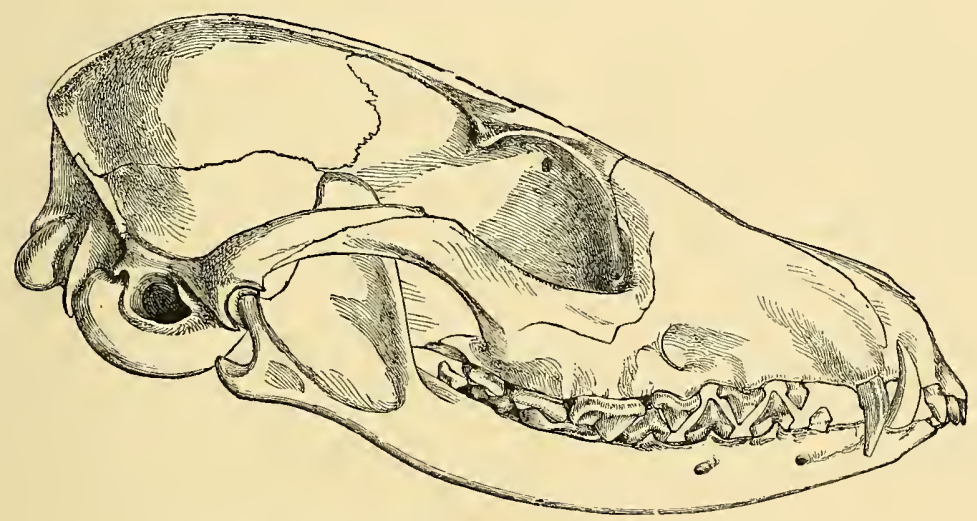

Fig. 24.-Skull of Vulpes chama (Proc. Zool. Soc.).

This genus includes the well known English fox, which under slight modifications is found throughout the whole of the northern regions of the old world and other Asiatic, North American and African species.

The only South African representative, described below, is at once distinguishable from the jackals by its much longer tail, its smaller size, and different colouration. 


\section{Yulpes chama. The Silver Fox.}

Canis chama, A. Smith, S. Afr. Quart. Journ. ii, p. 89 (1834) ; P. L. Sclater, Proc. Zool. Soc., 1875, p. 81, pl. xvii.; Mivart, Monogi. Canidae, p. 140, pl. xxxiii. (1890).

Canis variegatoides, apud Layard, Cat. Mamm. S. Afr. Mus. p. 30 (1861) (nec Smith).

Fennecus caama, Gray, Proc. Zool. Soc., 1868, p. 520, fig. 7 [skull].

Vernacular Names.--Silver or Vaal Jackal of the Colonists; Asse apud Smith.

Description.-Form slender and delicate, with long limbs and tail; general colour silvery grey above and on the sides, fur very soft and thick, under-fur pale lavender-slate at the base, getting paler above, the longer projecting hairs having black tips and a broad white subterminal band, lower sides and below yellowish with a rufous tinge; head pale rufous, intermingled with white hairs, darker on the muzzle; upper lip towards the angle of the mouth, lower lip and chin very dark brown; ears large, about $3 \frac{1}{2}$ inches long, covered posteriorly with short soft reddish brown hairs; anteriorly with a few long white hairs, a pale yellowish patch at the base of the ears; legs becoming paler towards the toes, with a distinctly marked black band between the knee and hock of the hind leg; tail long, very thick and bushy, mingled yellow and black with black tip, hairs woolly with black extremities.

Skull slender, with post-orbital processes little developed and concave above; the anterior internal cusp of the upper carnassial tooth well developed.

Dimensions.-Of a mounted specimen; head and body 23.50 ; tail 12.50; hind foot 5.25 ; from ear opening to nose 6.0 ; skull length 4.53 ; breadth 2.45 ; upper cheek teeth 2.40 .

Distribution.-This little fox seems to be generally distributed over South Africa, though by no means common; it was described originally from Namaqualand, but extends eastwards as far as Grahamstown and the uplands of Natal, and appears fairly common in Beaufort West; north of the Orange River it is distributed through German South-west Africa, Griqualand West and the Orange Free State; the South African Museum has examples from Beaufort West, Caledon and the neighbourhood of Cape Town, where it however is not common.

Habits.-Little is recorded about this fox; it appears to be nocturnal and extremely wary, and its diet usually consists of insects and fruit. It has never been known to injure stock. 


\section{Genus OTOCYON.}

Otocyon, Wiegmann, Archiv. f. Naturg. iv, p. 290

(1838) O. megalotis.

Fox-like animals with four toes to the fore, five to the hind feet, and with very long ears.

Skull also resembling that of the smaller foxes.

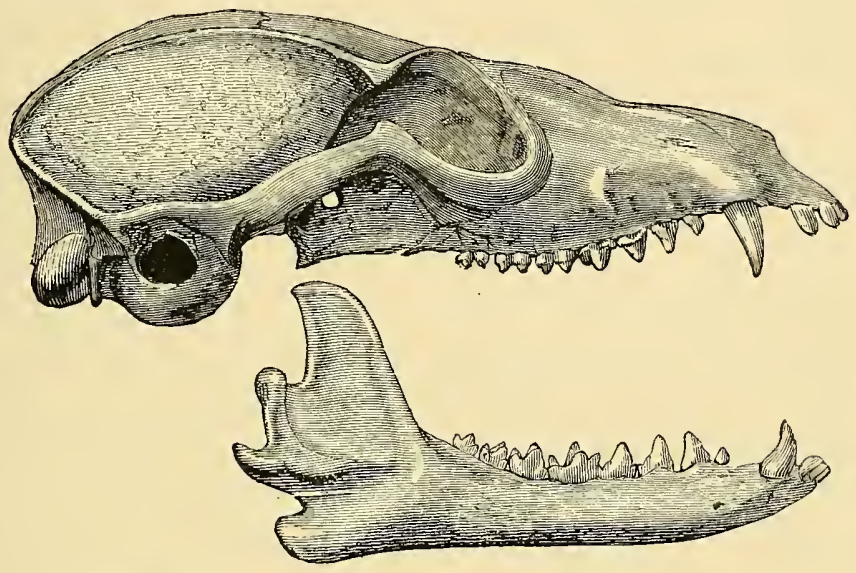

Fig. 25.-Skull of Otocyon megalotis (Proc. Zool. Soc.).

Dentition.-i. $\frac{3}{3}$, c. $\frac{1}{1}, \mathrm{pm} . \frac{4}{4}, \mathrm{~m} . \frac{3-4}{4}=46$ or 48 . This genus possesses a greater number of molar teeth than any other heterodont mammal and it is this which separates it from the preceding genus; the teeth are of the same general character as those of the foxes, but the cusps are more pointed especially in the case of the lower carnassial.

The species described below is the only known one.

40. Otocyon megalotis. Delalande's Fox.

Canis megalotis, Desmarest, Mammal. Suppl. i, p. 538 (1822) ; Smuts, Enum. Mamm. Cap. p. 15 (1832) ; A. Smith, S. Afr. Quart. Journ. ii, p. 90 (1834).

Canis lalandii, Desmoulins, Dict. Class. Hist. Nat. iv, p. 18 (1823).

Otocyon caffer, Wiegmann, Archiv. f. Naturg. iv, p. 290 (1838) ; Noack, Zool. Jahrb. iv, p. 166 (1889) [Kalahari]. 
Otocyon lalandii, Layard, Cat. Mamm. S. Afr. Mus. p. 31 (1861); Huxtey, Proc. Zool. Soc. 1880, p. 258, fig. 12 [skull].

Otocyon megalotis, Mivart, Monogr. Canidae p. 202, pl. xlv \& figs. 56.59 [skull] (1890); Lorenz, Ann. k7. Hofmus. ix, notiz. p. 67 (1894).

Literature.-Livingstone (1857), p. 50, its occurrence in the Kalahari ; Bryden (1893), p. 60, common in Bechuanaland; Millais (1895), p. 11, figured in a woodeut; Kirby (1896), p. 555, occurrence in the Eastern Transvaal.

Vernacular Names.-Motlose of Bechuanas (Livingstone); sometimes known as the Cape Fennec, a name which should be more correctly applied to $V$. chama.

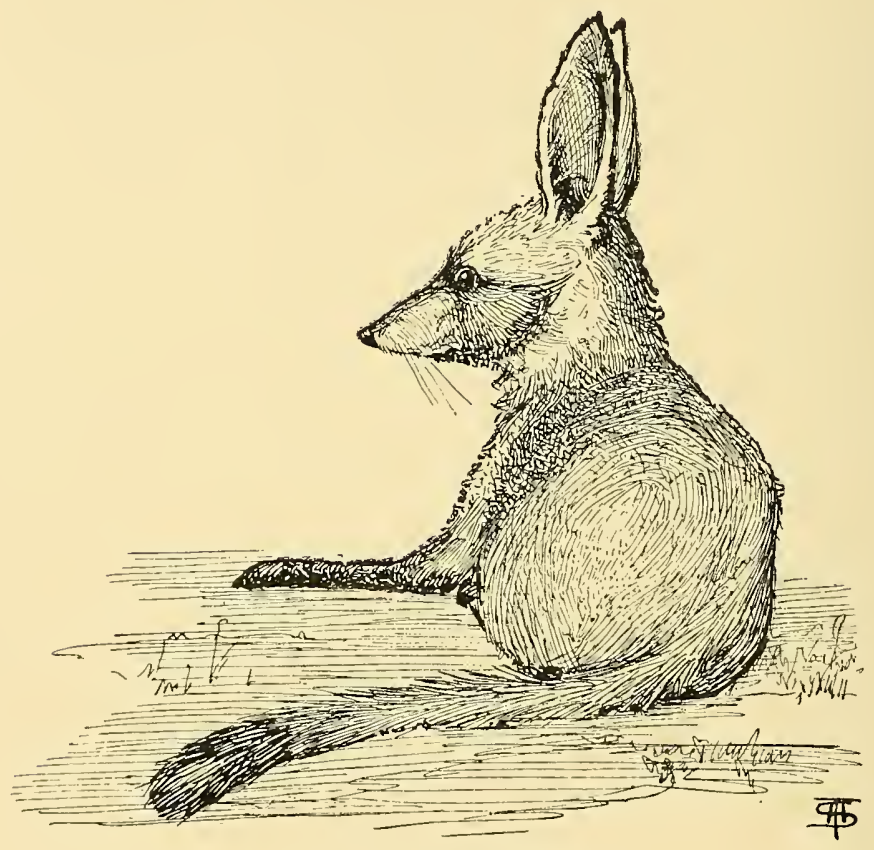

FIG. 26.-Otocyon megalotis.

Description.-In its slender form and general colour it somewhat resembles $V$. chama; the under-fur however, is a pale yellow and not slaty, the head shows no sign of reddish but has a dark streak running through the eyes and down the centre of the nose; the chin is dark brown and the rest of the under-surface very pale, almost white; the ears are very large for the animal being about $4 \frac{1}{2}$ inches 
in length, posteriorly and along the upper margins they are covered with thick soft dark brown fur, with a few white hairs anteriorly; the limbs grow darker towards the toes which are quite black; the tail is thick and bushy and somewhat pointed, the last third being black, the hairs are all yellowish with black tips, those towards the end of the tail being quite black.

The skull and dentition are described in the account of the genus.

Dimensions.-From a mounted specimen; head and body 25.0 ; tail without terminal hairs 10.50 , with 13.0 ; hind foot 5.25 ; from ear opening to tip of nose 6.0 ; skull length 4.30 ; breadth 2.51 ; upper cheek teeth $1 \cdot 35$.

Distribution.--Like Vulpes chama this fox is found only in the western parts of South Africa, though it extends northwards through the dryer parts of Central Africa to Somaliland; in the Colony it is said to reach as far east as Graaff Reinet and Uitenhage; it is certainly common at Beaufort West whence the South African Museum possesses an example and where it was sketched by Millais. It is found throughout German territory, the Kalahari, Bechuanaland, and perhaps the dryer portions of Rhodesia and the Transvaal as it is recorded from the eastern portion of that Republic by Kirby.

Habits.-This fox was originally obtained by the French traveller Delalande, and was described by Desmarest from his specimens.

It is purely nocturnal in its habits and found singly or in pairs; its food is said to consist of mice, birds, insects and fruit; others report termites alone form the bulk of its nourishment. It is easily tamed and becomes playful and affectionate, and is valued by the Bechuanas for its skin of which excellent karosses are made.

\section{Genus LYCAON.}

Type

Lycaon, Griffth, Cuvier's Anim. Kingd. v, p. 151 (1827)...L. pictus.

This genus resembles Canis in most respects, differing only in the fact that there are four toes on both fore and hind feet; the skull also is shorter and broader and the teeth more massive.

Only one recent species, that below described, is known, but in the cave-deposits of Glamorganshire in South Wales, a lower jaw found closely resembling that of the recent species, indicates that 
the genus had formerly in Pleistocene times a wider distribution than at present.

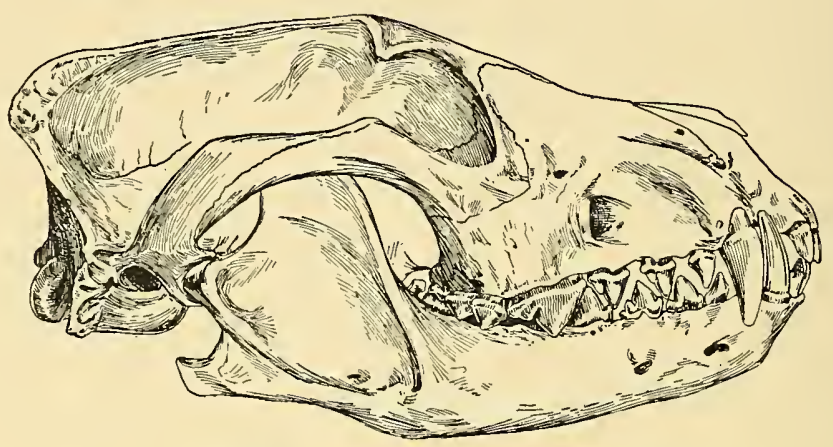

Frg. 27.-Skull of Lycaon pictus.

\section{Lycaon pictus. The Cape Hunting Dog or Wilde Honde.}

Canis aureus, apud Thunberg, Mem. Acad. Petersb. iii, p. 302 (1811) (nec Linn.).

Hyaena picta, Temminck, Ann. Gen. Sci. Phys. iii, p. 54, pl. xxxv (1820).

Hyaena venatica, Burchell, Travels, i, p. 456 (1822).

Lyeaon tricolor, Griffith, Cuvier's Anim. Kingd., v, p. 151 (1827).

Canis pictus, Smuts, Enum. Mamm. Cap., p. 14 (1832).

Lycaon typicus, A. Smith, S. Afr. Quart. Journ. ii, p. 91 (1834).

Lycaon venaticus, Gray, Proc. Zool. Soc., 1868, p. 497, fig. 1 [skull].

Lycaon pictus, Garrod, Proc. Zool. Soc., 1878, p. 373 [anatomy]; Mivart, Monogr. Canidae, p. 196, pl. xliv \& fig. 55 [skull] (1890).

Literature.-Masson (1776), p. 278, occurrence of "Wild Dogs" near Saldanha Bay; Sparrman (1785), p. 166, description of its habits in Caledon; Paterson (1790), p. 83, met this species in Uitenhage ; Burchell (1822), i, p. 456, described as a new species; ii, p. 229, further discussion and notes on systematic position ; Moodie (1835), i, p. 256, on its habits ; Harris (1840), figured on pl. xxx, fig. 3; Delagorgue (1847), p. 374, occurrence in Zululand with discussion of habits and systematic position; Cumming (1855), i, p. 169 account of meeting with wild dogs in Griqualand West; Grout (1863), p. 293, native names and habits in Zululand; Drummond (1875), p. 311, account of habits in Zululand; Selous (1881), p. 356, observation on a solitary wild dog pursuing a sable antelope; Holub (1882), i, p. 302, note on habits; Nicolls and Eglington (1892), p. 93, description, distribution and habits; Bryden (1893) p. 314, occurrence in Khama's country; Kirby (1896), p. 555, on habits, distribution and 
vernacular names in the Eastern Transvaal; Kirby (1899), p. 324, distribution in Mozambique,

Vernacular Names.-Wilde Honde of the Colonists; Inkentyane (Drummond), Inkentshana (Kirby) of the Zulus; 'Budaja of Swazis (Kirby); Matshabidi of Basutos (Kirby); Ixwili of Amaxosa (Stanford).

Description.-Form, large and wolf-like; general colour, pale yellow with irregular dark brown markings, separating the yellow into patches, sometimes with white brown-margined patches, but the markings varying very much with individual specimens; fur coarse and woolly with no long straight hairs; muzzle, lower

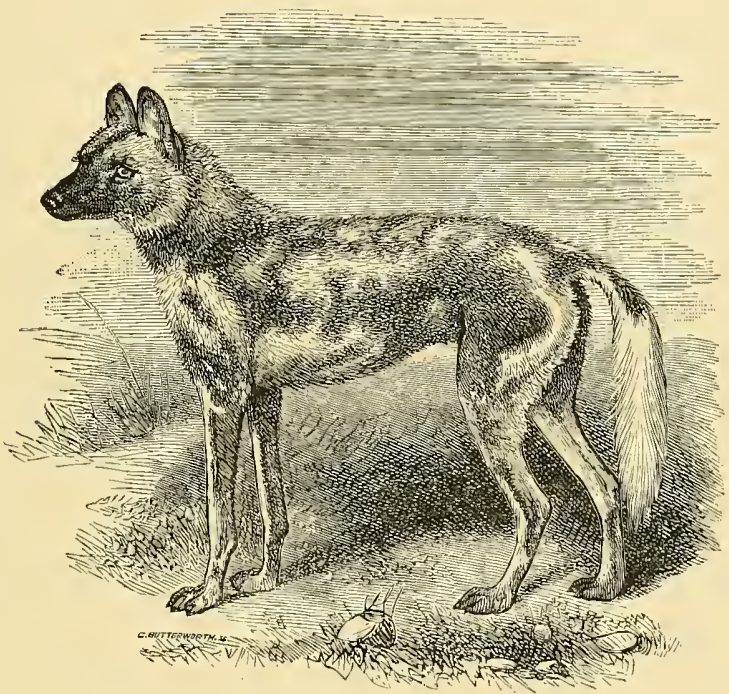

FIG. 28.-Lycaon pictus (after Flower).

cheeks, chin and throat brown or black, from the former passes back a band of the same colour to between the ears; ears large, wide, rounded and patulous covered posteriorly and along the upper margins with brown bairs, and anteriorly with a few long yellow hairs; limbs mottled with yellow, white and brown like the back; with four toes only, to both fore and hind feet as in Hyaena; tail short, rather bushy, mottled like the back with the distal half pure white.

Skull and dentition as described above. 
Dimensions.-From a mounted specimen; head and body 45.5 ; tail 11.50 , with terminal hairs 14 ; hind foot 8.25 ; from ear opening to tip of nose 9.50 ; skull length 8.25 ; breadth 5.30 ; upper cheek teeth, $3 \cdot 0$.

Distribution.-The hunting dog is found over the greater part of eastern and southern Africa, from Abyssinia and Somaliland through Uganda and East Africa to the Colony. It is still found in the Colony, especially in unsettled districts such as the Addo and Fish River bush, and is also recorded from all the other territories and states which go to form South Africa.

Habits.-This animal though not distinguished till 1821 by naturalists in Europe was previously well known to the colonists, and is mentioned by some of the earlier writers ; and in consequence of its peculiar habits has always attracted a good deal of attention.

The wilde honde is always found in packs of from four to sixty, but usually about fifteen individuals; they travel rapidly and are migratory, seldom remaining long in one place. Mr. Selous gives an account of a solitary individual whom he observed pursuing a sable antelope, but this is quite exceptional. They travel both by day or night in a long untiring gallop, not very speedy but which is effective in exhausting their victims.

Cumming states that they have three distinct cries, a sharp angry bark of surprise, a chattering somewhat like that of monkeys chiefly heard at night, and thirdly and most commonly a soft and melodious "ho, ho," like the second note of the cuckoo; this is used to rally the pack, and is mentioned by many other observers.

Their food consists of the sheep and cattle of the farmer, and the larger antelopes, even the sable and gnu; they appear to be always ravenous, and a troop has been seen to kill, tear to pieces and completely clear away a large buck in about fifteen minutes.

They hunt their prey like well trained hounds. Drummond says: "It is a marvellous sight to see a pack of them hunting, drawing cover after cover, their sharp bell-like note ringing through the air, while a few of the fastest of their number take up their stations along the expected line of the run-the wind, the nature of the ground, and the habits of the game all taken into consideration with the most wonderful skill. And then to see them after they have found, going at their long unswerving gallop so close together that a sheet might cover them, while those which had been stationed or had stationed themselves, it is hard to say which, drop in one by one as the others find themselves unable to make the running 
any longer; and the chase, generally a gnu or waterbuck pressed first by one and then another, though it may distance the pack for a while soon comes back to it, and is in the end almost invariably run into."

They always attack their victim just below the tail and try to tear out the viscera.

The visits of these animals are greatly dreaded by farmers, as they kill more than they eat, and as many as sixty or seventy sheep or goats are destroyed in one night out of each of which only a few mouthfuls are taken. Drummond states that he had seen them dash into a herd of cattle feeding not a hundred yards from the house, and drive out a beast, disappear over the rising ground with it, and kill it and pick its bones before the saddle could be placed on the horse to follow.

Smuts states that ten to twelve puppies are born at a birth; the females bring forth their young in large holes or eartbs on the open plains, which are connected with one another by underground passages; in these earths they never take refuge, but if pursued make off into bush.

In disposition this animal is exceedingly bold, and shows little or no fear of man, and instances are even known of their attacking, or at any rate making very unpleasant demonstrations towards a man on foot, though they will not meddle with a man on horseback; they have been occasionally caught and tamed, but apparently never become quite docile.

Moodie states that when crossed with domestic dogs they produce a mongrel offspring of bad character.

\section{Division ARCTOIDEA.}

This section of the Carnivora consists of three families; those containing the bears, the racoons, and the weasels, of which only the last-named have South African representatives.

In external appearance no very marked character separates this section from the other two previously considered, but in their osteology and anatomy they possess many points in common, and show considerable distinctions from the members of the other groups, of which the following are the most important.

In the skull the auditory bulla is simple and not divided inter- 
nally into two separate chambers, and the inferior lip of the auditory meatus is prolonged into a short spout; the mastoid process is separated from the paroccipital and is very prominent; the condylar foramen is quite distinct and not fused with the foramen lacerum posterius; there is no caecum to the intestine, and there are invariably five toes to both fore and hind feet armed with non-retractile claws.

\section{Family MUSTELIDAE.}

This family contains the Otters, Weasels and Badgers, and is characterised by the absence of an alisphenoid canal to the skull, by the number of molar teeth, either $\frac{1}{2}$ or $\frac{1}{1}$, and by the fact that the inner tubercular portion of the single upper molar is longer than the outer secant portion.

The family is a large one and widely distributed, especially in the northern regions; only four genera containing five species reach South Africa.

\section{Key of the South African Genera.}

A. Feet short and rounded; hind toes webbed; habits

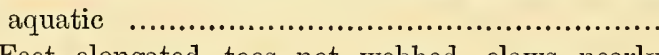

$B$. Feet elongated, toes not webbed, claws nearly straight; habits terrestrial.

a. Form stout; tail short; external ear rudimentary. Mellivora, p. 109.

b. Form long and slender; tail more than half the length of the body, external ears present.

$a^{1}$. Form mungoose-like with pointed snout, and three premolars above and below ..............
Form weasel-like, very short on the legs as compared with the length of the body; snout somewhat rounded, only two premolars above and below

Lutra, p. 106.

Zorilla, p. 112.

Poecilogale, p. 114.

\section{Genus LUTRA.}

Lutra, Erxleben, Syst. Regn. Anim. p. 445 (1777) ......L. vulgaris. Aonyx, Lesson, Man. Mamm. p. 157 (1827).............. capensis.

Animals of aquatic habit, with rounded heads, elongated bodies, short limbs and webbed hind toes; claws sometimes well developed 
sometimes rudimentary; soles of the hind feet naked, but not quite as far as the heels; ears small.

Skull large and depressed, with a large brain case, and a short facial portion.

Dentition, i. $\frac{3}{3}$, c. $\frac{1}{1}$, pm. $\frac{4}{3}, \mathrm{~m} \cdot \frac{1}{2}=36$; upper carnassial with a sharp-edged tricuspid blade and a large inner lobe, anterior premolar small, set inside the regular tooth line.

All Otters resemble one another very closely externally and are difficult to distinguish; Mr. Thomas' memoir in the Proceedings of the Zoological Society for 1889 is here followed.

Otters are spread all over the world except in Australia; only two species are found in the Ethiopian Region, and both of these reach South Africa.

\section{Key of the South African Species.}

A. Larger, head and body about 30 inches; claws quite rudimentary.... L. capensis, p. 107.

$B$. Sinaller, head and body about 20 inches; claws well developed

L. maculicollis, p. 108.

\section{Lutra capensis. The Cape Otter.}

Lutra capensis, Schinz, Cuvier's Thierr. i, p. 214 (1821); Thomas, Proc. Zool. Soc. 1889, p. 196.

Lutra inunguis, F. Cuv. Dict. Sci. Nat. xxvii, p. 247 (1823); Smuts, Enum. Mamm. Cap. p. 13 (1832); A. Smith, S. Afr. Quart. Journ. ii, p. 84 (1834); Noack, Zool. Jahrb. iv, p. 168 (1889) [Lake Ngami]. Aonyx delalandi, Lesson, Man. Mamm. p. 157 (1827); Layard, Cat. Mamm. S. Afr. Mus. p. 28 (1861).

Literature.-Moseley (1892) p. 132, habits and occurrence near Simonstown ; Kirby (1896) p. 556 occurrence in Eastern Transvaal.

Vernacular Names.-Otter of the Colonists ; Intini of Swazis and Zulus (Kirby) and Amaxosa (Cloete); Itini of Basutos (Kirby.)

Description.-Form robust, the largest of all otters except the Brazilian; general colour rich dark brown, woolly under-fur brown, somewhat lighter towards the base, bristly hairs also brown, below a little lighter; all the fur smooth and short; head broad, tip of the nose, upper lip, cheeks, chin and throat white, gradually shading into brown on the chest and shoulder; nose pad broad, not 
connected with the upper lip by a bare line; whiskers white; ears short, only about an inch in length, flattened against the sides of the head and covered with brown fur; limbs short and stout; toes with no trace of claws on the fore-feet, but the third and fourth toes of the hind feet bearing a small, flat, rounded nail; only the bases of the toes of the fore-legs webbed, between those of the hind foot the web extends to the distal joint; tail thick at the base, tapering, covered, like the body, with short fur.

Young with longer and rougher fur and a slightly shorter tail.

Dimensions.-From a large mounted specimen in the South African Museum; head and body 32.0 ; tail 18.0; from ear opening to tip of nose 5.50 ; hind foot 6.50 ; skull length 5.45 ; breadth 3.60 ; upper cheek teeth 1.58 .

Distribution.-This otter is found over the greater part of Africa southwards from the Gold Coast on the west and Zanzibar on the east; it seems to be fairly common in the Colony, especially along the coast and elsewhere, wherever suitable conditions exist; it also occurs in Natal, the Transvaal and Rhodesia, including Lake Ngami, and the Zambesi River. It is not at all rare in the neighbourhood of Cape Town and a large male example was quite recently received from the Lorenz River, near Somerset West, weighing no less than $31 \mathrm{lbs}$.

Habits.-Little is recorded about the habits of this otter, probably it resembles the European species in this respect.

The Cape otter, however, is often found near the sea, in places where there are no streams, and probably are in some places adapting themselves for marine life; their food doubtless consists chiefly of fish, where these are absent, as is often the case in South African Rivers, it contents itself with other fresh-water animals especially crabs and frogs; when an opportunity presents itself it will destroy ducks and other water fowl.

\section{Lutra maculicollis. The Spotted-necked Otter.}

Lutra maculicollis, Lichtenstein, Arch. f. Naturg. i, p. 89, pl. ii, fig. 1 (1835) ; Thomas, Proc. Zool. Soc. 1889, p. 196.

Hydrogale maculicollis, Gray, Proc. Zool. Soc. 1865, p. 132 [fig. of skull].

Description.- General colour dark brown, darker than the other species, with a thick woolly under-fur; below slightly paler; upper and lower lips white; throat and chest pale, spotted with 
light red; fore and hind feet each with five well developed strong claws, all the toes, both fore and hind, fully webbed to the tips; tail coloured like the body and but slightly shorter than it.

Dimensions. -From a skin ; head and body 21.0 ; tail 14.0 ; hind foot about 4.0 ; from ear to nose-tip about 3.0 ; skull length 4.0 ; breadth 2.3 ; upper cheek teeth 1.2 .

Distribution.-The spotted-neck otter was described by Lichtenstein, and the specimens were said to have obtained in the Bambusbergen in the north-eastern portion of the Colony; it is reported from West and South-east Africa, from Liberia, the Camaroons, Angola, Nyasaland and Natal; the South Atrican Museum has an example obtained in the Waterberg district of the Transvaal.

\section{Genus MELLIYORA.}

Type.

Mellivora, Storr, Prodrom. Method. Mamm. p. 34 (1780) ...M. ratel. Body stout, limbs short and strong, fore claws large and well developed, tail short, external ear rudimentary; mammae four in

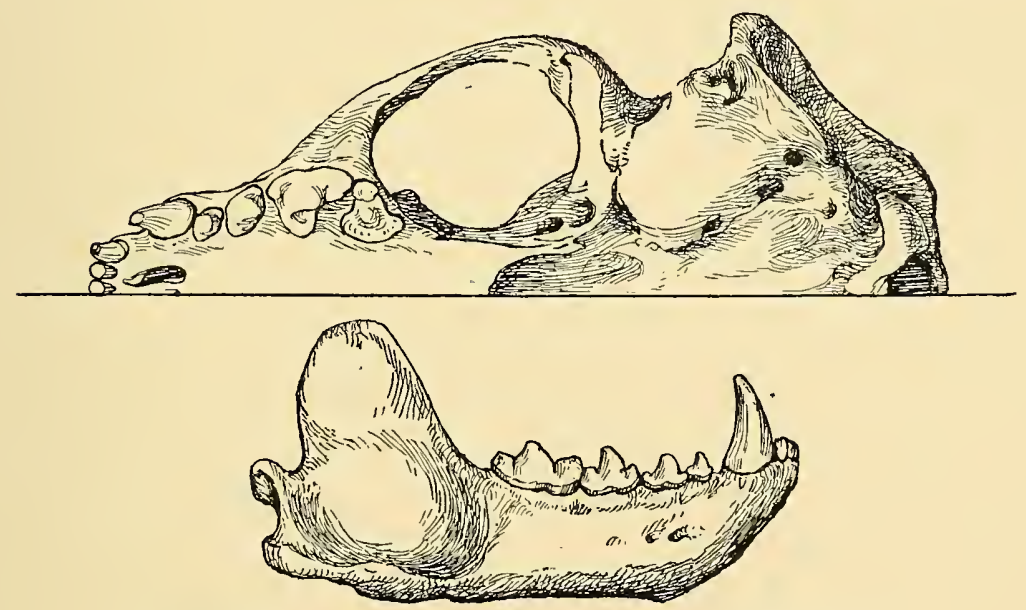

FIG. 29.-Left half of palate and lower jaw of Mellivora ratel.

number; anal glands developed, two in number; sole of the hind foot naked to the heel.

Skull with the lower jaw held in its place by the projection of the edges of the glenoid cavity as in the European badger. 
Dentition.-i. $\frac{3}{3}$, c. $\frac{1}{1}, \mathrm{pm} . \frac{3}{3}, \mathrm{~m} . \frac{1}{1}=32$; no lower tubercular molar; the upper molar with a very small outer and very large inner rounded lobe, upper carnassial large with the inner cusp quite at its anterior end.

In addition to the South African species another closely allied form, distinguished by the absence of the white dividing band between the grey of the back and the black of the belly, is found in Southern Asia from Transcaspia to India.

\section{Melliyora ratel. The RAteL.}

Viverra ratel, Sparrman, K. Vet. Akad. Handl. Stockholm, xxxviii, p. 147, pl. iv, fig. 3 (1777).

Viverra capensis, Schreber, Säugeth. iii, p. 450, pl. exxv. (1778).

Ursus mellivorus, G. Cuvier, Tabl. Elem., p. 112 (1798).

Meles mellivora, Thunberg, Mem. Acad. Petersb. iii., p. 306 (1811).

Gulo capensis, Desmarest, Mamm. p. 176 (1820); Smuts, Enum. Mamm. Cap. p. 11 (1832).

Gulo mellivora, A. Smith, Descr. Cat. S. Afr. Mus. p. 17 (1826).

Ratellus typicus, A. Smith, S. Afr. Quart. Journ. ii, p. 83 (1834).

Mellivora ratel, Layard, Cat. Mamm. S. Afr. Mus. p. 26 (1861); Bocage, Jorn. Sci. Lisb. (2) i, p. 184 (1889) [habits] ; Matschie, Säugeth. Deutsch-Ost-Afrikas, p. 84, fig. 49 (1895).

Mellivora leuconota, P. L. Sclater, Proc. Zool. Soc. 1867, p. 98, pl. viii. [young specimen]; $i d . i b i d .1871$, p. 232.

Literature. - Kolben (1731) ii, p. 124, described amusingly but somewhat inaccurately as the Rattle-Mouse; La Caille (1763), p. 182, described as the "Blareau puant" at considerable length; Sparrman (1785) ii, p. 194, figured and described with an account of its habits ; Barrow (1801), p. 293, on its habits as a honey eater and its tenacity of life ; Kirby (1896), p. 556, occurrence in the Eastern Transvaal with vernacular names; Kirby (1899), p. 324, distribution in Mozambique.

Vernacular Names. - Ratel or Honey-Ratel of Colonists; Icelesi of Amaxosa (Stanford); Sisele of Basutos; Indundundwana or Insele of Swazis and Zulus (Kirby).

Description.-Form stout and thickset; general colour above from forehead to base of tail greyish brown, becoming darker posteriorly; sides and lower parts quite black including the face and ears; a band of pure white, about an inch in breadth, runs along each side dividing the grey back from the black under-parts; fur very coarse, no under-fur; external ear completely absent; fore limbs very powerful, with nearly straight stout claws, of which the 
middle three are the longest, being over an inch in length; claws of the hind feet comparatively small; tail short, one fourth the length of the head and body, rather bushy, black except at the base where it is white. In the young the white lateral dividing line does not seem to be present.

Dimensions.-Head and body 32.0 ; tail 6.50 without, 8.30 with the terminal hairs; from ear opening to tip of nose 4.0 ; hind foot $5 \cdot 0$; skull length $5 \cdot 80$; breadth 3.40 ; upper cheek teeth $2 \cdot 30$.

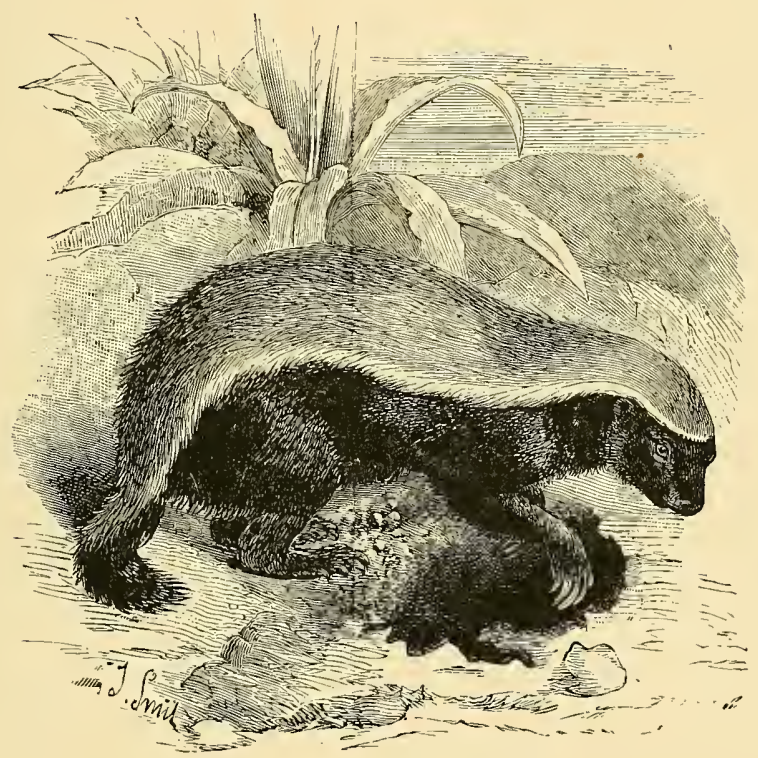

FIG. 30.-Mellivora ratel.

Distribution.- Found throughout Africa southwards from French Congoland in the west, and from Kordofan and Nubia in the east ; in South Africa it is plentiful everywhere, though it does not seem to be often seen owing to its retiring nature. There are examples in the South African Museum from the Albany and Cape divisions of the Colony.

Habits.-This animal, which is strictly nocturnal, is found chiefly in caves and rocky situations, and has its lair either among the roots of trees, or actually in a hollow tree, though according to Sparrman it does not climb trees. 
Its skin is very thick, so much so that the sting of a bee cannot penetrate it; it is also very loose so that a dog cannot well obtain a firm grasp of the animal, and even then it can nearly always turn and bite its assailant.

The ratel is practically omnivorous, it robs the poultry yard and eats snakes; a cobra has been found in the stomach of one by M. Bocage. But perhaps its favourite and most notorious food is the comb and honey of wild bees ; by Sparrman it is said to destroy the nest and carry off the honey to some special repository; it has also been related that it is sometimes able to find the bees' nest by following the honey-guide (Indicator) as it flutters through the forest.

When pursued it takes refuge, as a rule, in a hole, and bites most savagely and tenaciously; it further defends itself by emitting an offensive odour from its anal glands. It is very difficult to kill, only, it is said, by actually crushing its skull or by stabbing to the heart can this be effected.

Though dangerous to tackle, when once in captivity it soon becomes tame and makes an amusing pet. It has a curious habit of turning constant somersaults when confined in menageries.

\section{Genus ZORILLA.}

$$
\text { Type. }
$$

Zorilla, Is. Geoffr. Dict. Class. Hist. Nat. x, p, 215 (1826)...Z. striata. Ictonyx, Kaup, Thierreich i, p. $352(1835)$................... striata.

Form somewhat slender with short limbs, the fore feet large, with five stout non-retractile claws, the first and fifth being slightly shorter; tail long, with long hairs, giving it a bushy appearance.

Skull of much the same general proportions as that of a mungoose, but with the bony palate prolonged considerably back behind the level of the molars, and the posterior wing of the pterygoid bones connected with the auditory bulla by means of a thin bony bridge.

Dentition. - i. $\frac{3}{3}$, c. $\frac{1}{1}, \mathrm{pm} . \frac{3}{3}, \mathrm{~m} \cdot \frac{1}{2}=34$; teeth sharp and pointed, upper and lower carnassials with sharp well-marked inner cusps, and the latter with a talon.

Several of these small skunk-like forms are found in Africa; only the earliest and best known species reaches South Africa. 


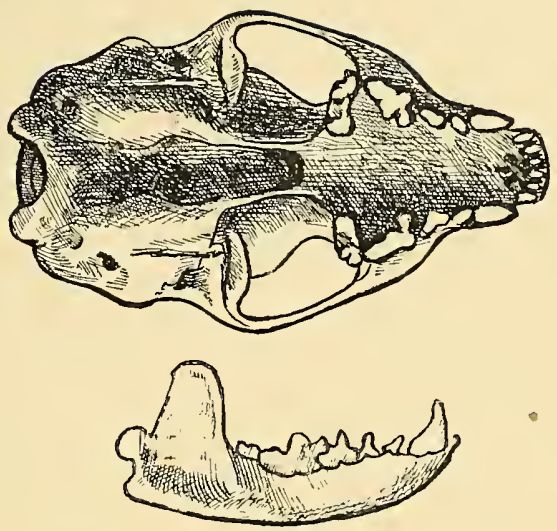

FIG. 31.--Palatal view of skull and lower jaw of Zorilla striata.

\section{Zorilla striata. The Striped Muishond.}

Vive rra zorilla, Erxleben, Syst. Regn. Anim. p. 492 (1777); Thunberg, Mem. Acad. Peters. iii, p. 306 (1811).

Viverra striata, Shaw, Gen. Zool. i, pt. 2, p. 387, pl. xciv (1800).

Mephitis capensis, A. Smith, Descrip. Cat. S. Afr. Mus. p. 20 (1826).

Mustela zorilla, Smuts, Enum. Mamm. Cap. p. 12 (1832).

Putorius zorilla, A. Smith, S. Afr. Quart. Joum. ii, p. 84 (1834).

Zorilla striata, Layard, Cat. Mamm. S. Afr, Mus. p. 28 (1861).

Vernacular Names.-Stink or Getrepte Muishond, or simply Muishond of the Colonists; Iqaqa of Amaxosa (Cloete).

Description.-Form slender; general colour black with four longitudinal stripes of white divided by three narrower black ones which run from behind the occiput to the root of the tail, the median black stripe being somewhat widened over the pelvis; rest of the body and limbs entirely black. A woolly under-fur is present as well as an outer longer fur, the latter being very soft and fine. Fore feet with large claws, especially those of the three middle toes; claws of the hind feet much smaller; all slightly curved. Head with a pointed snout, black with three white spots on the forehead and cheeks; ears small and rounded, black with narrow white margins along the upper part of conch; tail nearly as long as the head and body, clothed with long hairs mingled black and white in different proportions; tip generally white; young, with a very short completely white tail. The skull is described above. 
Dimensions. - Measured in the flesh by Mr. A. Ross; head and body 14.75 ; tail without hairs, $9 \cdot 25$, with, 12.50 ; from ear opening to tip of nose 2.60 ; hind foot 2.50 ; skull length 2.50 ; breadth $1 \cdot 60$; upper cheek teeth $1 \cdot 0$.

Distribution. - Central and South Africa from Benguela, Uganda, and Mozambique southwards; found throughout all the country south of the Zambesi, and not uncommon in the neighbourhood of Cape Town. In the South African Museum are examples from Upington in Gordonia, from Namaqualand, the Cape and Albany divisions, and from near Johannesburg.

Habits. -This little animal seems to take the place of the weasels of Europe and the skunks of North America, to which latter they have many points of likeness, both in appearance and odour. It is nocturnal, spending the day in holes and recesses and issuing forth at night in search of food. M. Bocage states that it is a good digger, and that it does not climb trees, but that it can swim well when forced into water; when moving about it walks with its tail upright or carried forwards over its back.

Its food consists of small mammals, birds, birds' eggs, lizards and frogs, and it is a great poultry-yard thief. When irritated it emits, like most of the family, a most disgusting odour proceeding from the secretion formed in the anal glands; this odour closely resembles that of the American skunk, though perhaps it is not quite so strong and pungent; the act can always be performed at the will, and is usually indulged in when dogs are in pursuit. It is gentle and easily tamed, and becomes greatly attached to its master, and is most useful in keeping down the rats and mice in a house.

\section{Genus POECILOGALE.}

Poecilogale, Thomas, Ann. Mag. N. H. (5) xi, p. 370

Type.

(1883)............................................ P. albinucha.

Body very much elongated and legs very short, head somewhat truncated and rounded; the skull much shortened, and the auditory bulla so flattened that it is hardly noticeable, the opening of the meatus being anteriorly directed.

Dentition. -i. $\frac{3}{3}$, c. $\frac{1}{1}, \mathrm{pm} . \frac{2}{2}, \mathrm{~m} . \frac{1}{2}-\overline{1}=28$ or 30 ; anterior premolars quite absent with no trace even of the diastema where they should stand; the number of teeth, therefore, is much reduced as 
compared with Mustela, with which at one time the only species of the present genus was associated ; the second lower molar is present though very small in one out of three skulls available for examination.

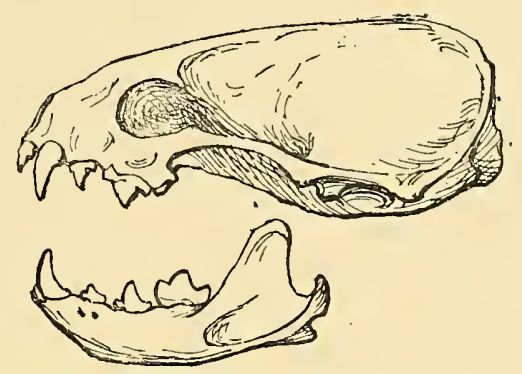

FIG. 32.-Skull of Poecilogale albinucha.

This genus was formed by Mr. Thomas for the reception of the single species below described.

\section{Poecilogale albinucha. The Snake Muishond.}

Zorilla albinucha, Gray, Proc. Zool. Soc. 1864, p. 69, pl. x.

Poecilogale albinucha, Thomas, Ann. Mag. N. H. (5) xi, p. 370 [woodcut of skull」 (1883).

Vernacular Name.-Slang muishond (snake-weasel) of the Colonists.

Description.-Body very elongated and weasel-like; fur short and soft, general colouration closely resembling that of the preceding species, but the whole of the top of the head from between the eyes is white or sometimes yellowish; along the back run three long, narrow black stripes, the middle one commencing on the occiput, the lateral ones behind the shoulder divided from one another and from the black of the body by four wider, white or sometimes pale yellow stripes, running from the white head to the root of the tail ; rest of the head, body and limbs shiny black; ear conch very small just at the junction of the black and white; limbs very short, the claws of the front a little longer than those of the hind feet, but not much curved; tail about half the length of the head and body, covered with long coarse white hairs.

Dimensions.-From a skin; head and body 12.0 ; tail 5.5 , with 


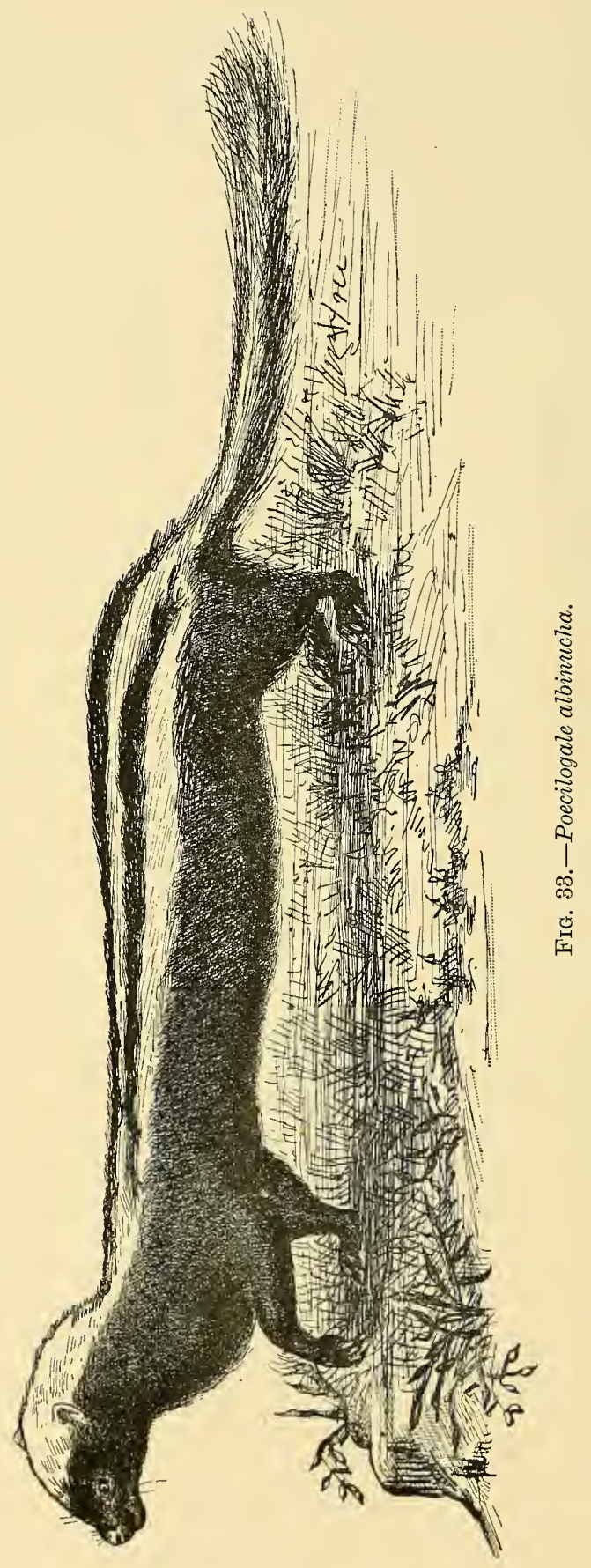


terminal hairs 6.5 ; hind foot 1.0 ; ear opening to nose-tip 1.25 ; skull length 1.90 ; breadth $1 \cdot 0$; upper cheek teeth $\cdot 4$.

Distribution.-Central and South East Africa, from Angola, Nyasaland, and German East Africa to Natal and the eastern part of the Colony; the South African Museum possesses examples of this species from the Cradock, Queenstown, and Pondoland divisions of the Colony, from the Rustenburg district of the Transvaal, and from Natal.

\section{Suborder PINNEPEDIA.}

This suborder contains the members of the Order Carnivora specially adapted to aquatic life, e.g., the eared seals, or otaries, the walrus, and the seals proper. They are distinguished from the land Carnivora chiefly by the structure of their limbs, which are modified for aquatic progression.

The two proximal segments (arm and forearm) are in these animals greatly shortened, while the third segment (hand and fingers) is elongated and expanded, and forms a flipper which is composed of five digits enveloped in a common integument; the tail is always very short.

The incisors are always fewer than $\frac{3}{3}$; the molar teeth are also much modified and simplified as compared with those of the land Carnivora; they are all more or less alike, having only two roots and compressed pointed crowns, and are never broad or tuberculated as in the land forms, nor are there ever differentiated carnassial teeth.

The brain is large; the kidneys are divided into a number of lobules; and the mammae, either two or four in number, are abdo. minal in position.

Of the three families into which the suborder is divided South Africa possesses a representative of one only, the Otariidae or eared seals, though two antarctic members* of the Phocidae or true seals have been reported to have reached our shores; the third family containing the walrus is exclusively arctic.

* Machrorhinus leoninus, the sea-elephant, and Ogmorhinus leptonyx the sea-leopard. 


\section{Family OTARIIDAE.}

These animals when on land have the hind feet turned forwards under the body to support the trunk and aid in progression; in addition a small external ear is present; skull with a post-orbital process and an alisphenoid canal.

Only two genera are now generally recognised, Otaria, containing only O.jubata, the Patagonian sea-lion, and Arctocephalus described below containing all the other species.

\section{GenUS ARCTOCEPHALUS.}

Arctocephalus, F. Cuvier, Mem. Mus. Hist. Nat. xi,

Type.

p. 205 (1824)

A. ursinus.

Head rounded, eyes large, pinna of the ear narrow and pointed; skin of both the limbs extending beyond the nails with a lobed margin deeply incised on the hind feet; nails small, sometimes rudimentary or absent.

Skull with a flat palate and a hook-like process to the pterygoids.

Dentition.-i. $\frac{3}{2}$, c. $\frac{1}{1}, \mathrm{pm} . \frac{4}{4}, \mathrm{~m} . \frac{1-2}{1}=34$ or 36 ; milk teeth shed a few days after birth; molars all of the same pattern usually single-rooted with a single, pointed cusp and smaller accessory ones in front and behind.

If the Patagonian sea-lion be excluded, the number of wellestablished species of this genus is eight; of these, four, among which is the Cape species, are distinguished by the possession of a woolly under-fur below the long stiff bristles, and are known as fur-seals; the most important of these commercially is the North Pacific species (A. ursinus), from which the largest proportion of the world's "seal skin" is now obtained, and which has been the object of so much negociation and diplomatic controversy between England and the United States. The other two are $A$. australis, from the South American coasts, and $A$. forsteri, from the Australian and New Zealand coasts, both of which are now very scarce and therefore not considered to be worth pursuit.

The other four species, A. stelleri from the North Pacific, $A$. californiana from California, and $A$. hookeri and $A$. lobatus from Australian seas, are all hair seals with no woolly under-fur, and commercially speaking comparatively valueless. 

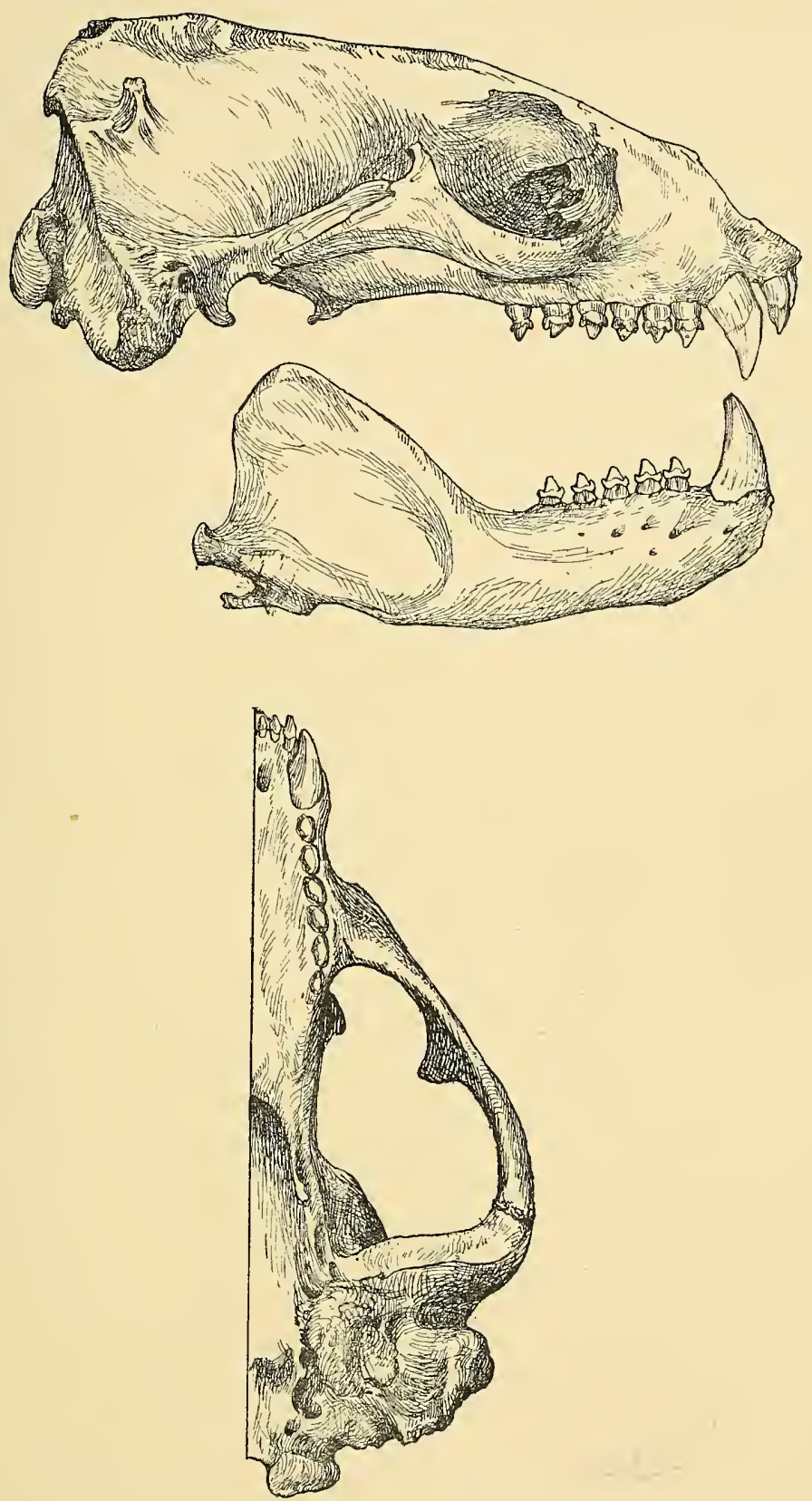

FIg. 34.-Skull of Arctocephalus pusillus. 


\section{Arctocephalus pusillus. The Cape Sea-Lion or Robbe.}

Phoca pusilla, Schreber, Säugeth. iii, p. 314, pl. lxxxv, (1778) ; Smuts, Enum. Mamm. Cap. p. 31 (1832).

Phoca antaretica, Thunberg, Mem. Acad. Petersb. iii, p. 221 (1811).

Otaria peronii, Desmarest, Mamm. p. 250 (1820); A. Smith, S. Afr. Quart. Journ. ii, p. 126 (1834).

Otaria delalandii, Gray, Proc. Zool. Soc. 1859, p. 107, pl. lxix. [skull].

Aretocephalus ursinus, apud Layard, Cat. Mamm. S. Afr. Mus. p. 40 (1861) [nec Linn.]

Arctocephalus antarcticus, Allen, Bull. Mus. Comp. Zool. ii, p. 45 (1870).

Imterature.-Jardine, South African Quart. Journ. i (1832), p. 286, account of industry; Jackson, Report of the Beliring Sea Commission (1893) p. 154, Report on the Condition of the Seal Fishery on the Coast of the Cape of Good Hope.

Vernacular Names.-Seal, Sea-dog or Robbe of the Colonists.

Description.-General colour rich brown, rather darker on the muzzle and lighter on the hind neck; a soft light brown woolly under-fur is entirely covered and concealed by coarse bristle-like hairs, lighter at their base, browner at their tips; head massive, whiskers consisting of a very small number of exceedingly thick, stiff bristles; external ear narrow and pointed, about an inch and a half long; fore limbs converted into flippers enclosed in a common integument, which is produced about half an inch beyond the end of the digits, hardly excised into lobes but distinctly scalloped; no trace of nails or claws; hind limb directed forwards, the integument produced far beyond the digits and deeply incised into thin flipper-like fingers; the three middle toes with large claws, the fifth toe with only a rudiment and the first toe without even this; tail very short.

The old males have a well-developed mane of long hairs all round the neck; the females are much smaller than the males and have no trace of the mane.

The young when born are jet black, but after a few months they become silvery grey from the gradual development of white tips to the hairs; there are present, too, in the young five rudimentary nails on the toes of the fore feet.

Dimensions.-From a mounted male specimen; head and body $6 \mathrm{ft} .1$; tail 3.0 ; hind foot to nails 13.0 , to end of projecting integument 18.0 ; from ear opening to tip of snout $9 \cdot 0$; skull length 11.0 ; breadth 6.5 ; upper cheek teeth 4.0 . A very old male 
measured in the flesh about $8 \mathrm{ft}$. from the nose to the root of the tail, an average female about $4 \mathrm{ft} .4$.

Distribution.-The coasts of South-western Africa extending

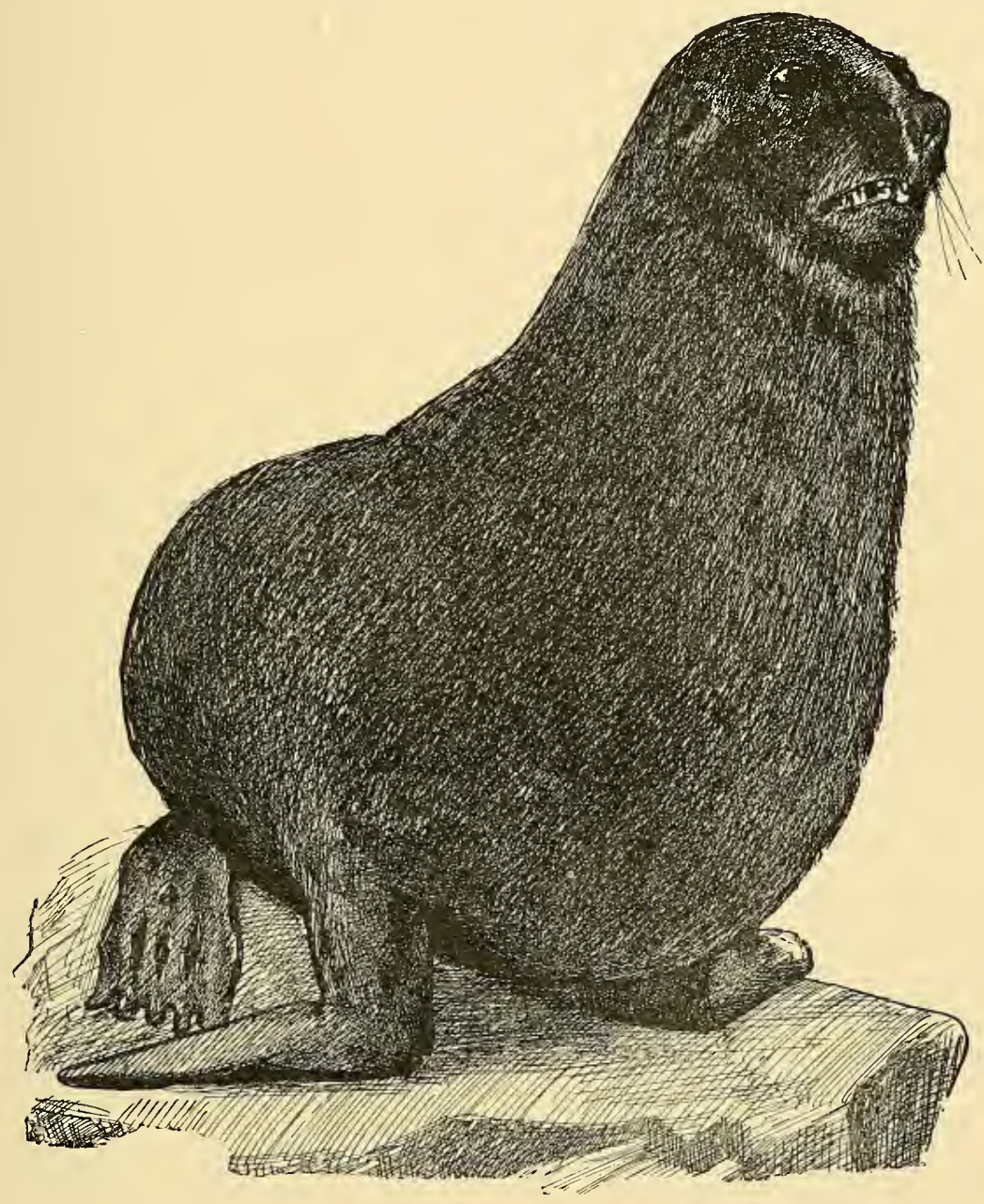

FIG. 35.-Arctocephalus pusillus.

northwards to Hollam's Isle, South of Walfisch Bay, and perhaps further north to Cape Cross, and eastwards to Bird Island in Algoa Bay. 
Habits.-The name applied to this species is founded on a plate of a young individual in Schreber's Saügethiere, and this again is taken from Buffon's description of a specimen stated to have come from India, but which no doubt really reached Europe from the Cape. In consequence of this several other names have been assigned to the species.

Compared with what has been learnt about the Northern Pacific fur-seal, these animals are very little known.

They resort to land twice a year, in winter between June and August when they shed their fur, and it is chiefly males that then arrive, and in summer between November and January when they come for breeding purposes; their migrations are irregular, and they can be seen at any time along the coast singly or in pairs. Their food consists apparently entirely of small fish.

The males arrive at maturity at three years, and the very old males, which reach an enormous size and fight very desperately at the breeding times, are locally known as " big wigs."

The chief breeding islands (these animals never seem to land on the mainland) are as follows:-Hollam's Isle, south of Walfisch Bay, Long Island, near Angra Pequena, Jacob's Rock in Saldahna Bay, Robbensteen in Table Bay, and Dyer's Island off the Caledon Coast. To these in November the females come and give birth to two pups; the period of gestation is just twelve months, as the female takes the male again immediately after the birth; the pups are suckled for about six months, they have a loud and piercing cry resembling that of an infant, and their teeth are sharp from quite an early age. Should they lose their mother while still sucking they can as a rule obtain a foster-mother, as females will suckle pups not their own.

The seals are seldom if ever killed at sea, but only on the islands when they arrive for breeding or shedding their fur; at this time men armed with wooden clubs are sent to the islands for the purpose.

The number killed of late years has not been very great, as they have been nearly exterminated, and it is considered very desirable to allow them to increase. The fur is somewhat shorter and less abundant than in the Northern Pacific species, but still it sells well on the London market at perhaps an average price of $25 \mathrm{~s}$. a skin. 


\section{Order UNGULATA.}

In this order are comprised what we may roughly describe as the hoofed or herbivorous animals, such as pigs, deer, antelopes, sheep, oxen, tapirs, rhinoceros, horses, elephants, and hyraxes or dassies. Although some of these differ very markedly from one another not only in outward appearance but also in internal structure, the study of the large number of allied fossil forms tends to bring them together, but at the same time it is difficult to construct a diagnosis, which will accurately fit them all.

The following, however, are their most important characteristics:- Ungulates are terrestrial and mainly vegetable-feeding mammals, with limbs adapted to progression and not to prehension, with from five to only one digit usually ending in a solid hoof enclosing the last phalanx, though in some cases there are broad. blunt nails; no clavicles; humerus with no entepicondylar foramen ; scaphoid and lunar bones always distinct; a full set of milkteeth not completely replaced until adolescence; molars broad with ridged or tuberculated crowns.

This order containing the largest of all terrestrial animals is particularly well represented in South Africa. Out of twelve recent families usually recognised, six have representatives, six are absent, the most important of the latter being the deer (Cervidae), which are spread all over the rest of the world except Australia-the others are the peccaries (Dicotylidae), the camels (Camelidae), the chevrotains (Tragulidae), the prong-bucks (Antilocapridae) and the tapirs (Tapiridae).

The following key gives the most conspicuous characters by which the six represented families can be at once distinguished.

$A$. Never more than 4 toes to both limbs.

a. Two middle toes, the $3 \mathrm{rd}$ and 4 th, equal

and forming a symmetrical pair [Artiodactyla].

$a^{1}$. No incisors in the upper jaw; a ruminating stomach; 2nd and 5th digits incomplete [Pecora]. 
$a^{2}$. Horns always present in males at least, and consisting of a horny sheath enclosing a bony core ...................

$b^{2}$. Horns consisting of hairy skin enclosing a bony core.

Bovidae, p. 127.

Giraffidae, p. 258.

$b^{1}$. Incisors usually present in the upper jaw ; not ruminating [Suina].

$a^{2}$. Toes 4-4 subequal, all reaching the ground ; muzzle broad and rounded...

$b^{2}$. Toes $4-4$ outer pair not reaching the ground; muzzle forming an elongate mobile snout

b. The 3rd toe always larger than the others [Perissodactyla].

$a^{1}$. Only one toe developed to each foot Equidae, p. 282.

$b^{1}$. Three toes to each foot; median dermal horms on the nose.

Rhinocerotidae, p. 297.

$B$. Five toes to fore limbs (5th small and rudiHippopotamidae, p. 266.

Suidae, p. 272. mentary), 3 to hind feet; incisors triangular and sharp-pointed; small and rodentlike animals

Procaviidae, p. 308.

$C$. Five toes to each limb (only 3 hoofs on hind foot), of very large size with nostrils at the end of a long prehensile proboscis......

Elephantidae, p. 316.

\section{Suborder ARTIODACTYLA.}

The animals comprised in this suborder are those popularly known as cloven-footed; in these the third and fourth digits of both limbs are equally developed and are each provided with hoofs flattened on their inner surfaces so as to form a symmetrical pair, the middle line of the foot running between them (fig. 36), whereas in the Perissodactyla the middle line runs through the middle of the third toe. Other distinctive characters are as follows:-nasal bones not expanded posteriorly, no alisphenoid canal, dorso-lumbar vertebrae always nineteen in number; femur with no third trochanter, astragalus with two nearly equal facets for the articulation of the navicular and cuboid; premolars and molars dissimilar, the former usually with single, the latter with double lobes; stomach complex, caecum small, placenta diffuse or cotyledonary.

This suborder, although it can be traced back as far as the Eocene age, was not in early times nearly so widely diffused as the 
Perissodactyla, though now-a-days it has become the predominant group of the order and is widely spread all over the world except in the Australian region.

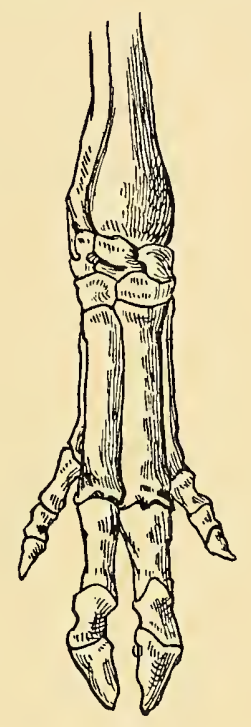

A

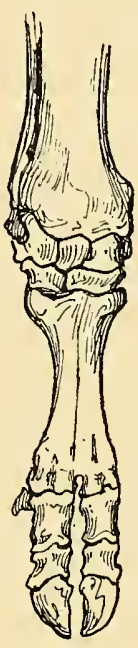

$\mathrm{B}$

FIG. 36.-Skeleton of the right fore feet of A, the pig, and $B$, the buffalo (Bos caffer), to show the modifications of the artiodactyle limb.

\section{Division PECORA.}

Artiodactyles with no incisors in the upper jaw, with selenodont molars, i.e., with folds of enamel forming a crescent-shaped pattern on the surface of the tooth after wear; with a ruminating stomach; usually with horns or antlers attached to the frontal bones; with the third and fourth metatarsals and metacarpals fused to form a cannon-bone and with the second and fifth toes small and sometimes wanting altogether, their metatarsals and metacarpals never being complete.

The stomach of the Pecora is a most complex organ and comprises four well defined cavities; these are (1) the rumen or paunch -much the largest-which has its mucous membrane closely covered with villi resembling pile or velvet; (2) the reticulum or 
honey-comb bag with the lining membrane arranged in shallow hexagonal cells;; (3) the psalterium or manyplies, the inner surface of which is composed of numerous longitudinal folds; (4) the abomasum or reed which is the digestive stomach proper. The food when swallowed is received in the paunch, and after being retained there for a period and undergoing a softening process, is regurgitated into the mouth where it undergoes the process known as "chewing the cud," that is retrituration by the molar teeth.

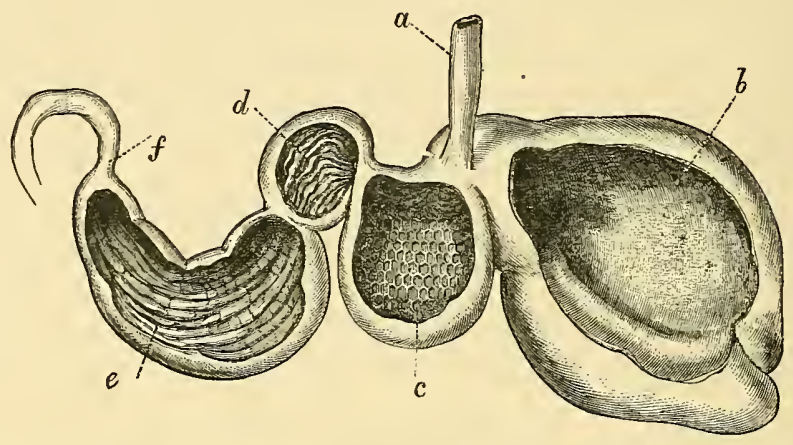

Fig. 37.-Stomach of a ruminant opened to show its internal structure, $a$, oesophagus, $b$, rumen or paunch ; $c$, reticulum or honeycomb bag; $d$, psalterium or manyplies; $e$, abomasum or reed ; $f$, duodenum. (From Flower.)

There are four generally recognised recent families of the Pecora easily distinguished by their horns. Of these South Africa possesses representatives of two, Bovidae and Giraffidae. The other two are (1) the Cervidae in which the horns, or rather antlers, are outgrowths of true bone covered during growth with a soft vascular skin, called "velvet," which peels off when the antler has attained its full size. Antlers are grown and shed periodically, as a rule annually, and are usually branched. This family is widely distributed over the New World, Europe, North Africa and Asia, but does not reach the true Ethiopian region south of the tropic of Cancer; (2) the Antilocapridae or prongbucks of North America in which there are branched horns fixed on to unbranched bony cores and in which the horns are shed periodically, a new one being formed under the old one on the bony core beneath. 


\section{Family BOVIDAE.}

Frontal appendages when present, consisting of a long bony process attached to the skull, termed the horn core; this is ensheathed with the true horn, which is therefore hollow, and consists of an epidermic development of hard fibrous matter; these horns are not periodically shed as is the case in the Deer family where the appendages which are of an entirely different nature consisting of bony matter only, and should more properly be called antlers.

Skull with one orifice to the lachrymal canal inside the orbit.

Lateral toes sometimes completely absent, sometimes represented by small false hoofs alone, but never with a well-developed skeleton.

Gall bladder always present; placenta with very numerous cotyledons.

Dentition, i. $\frac{0}{3}$, c. $\frac{0}{1}, \mathrm{pm} . \frac{3}{3} \mathrm{~m} \cdot \frac{3}{3}=32$, upper incisors and canines absent, lower canines resembling the insisors and following behind them without a gap, molars usually hypsodont (i.e., with long crowns).

This is a very extensive family numbering among its members antelopes, goats, sheep and oxen, and is found throughout Europe, Asia, Africa and North America.

The first section of the family containing the antelopes is specially characteristic of the Ethiopian region and South Africa is very rich in this group.

In the following account much use has been made of the "Book of Antelopes" by Messrs. P. L. Sclater and O. Thomas, a complete monograph of this group now in the course of publication.

As no less than twenty genera of this family are represented in South Africa, it will perhaps be most simple to give a key to the various subfamilies into which for the sake of convenience the family may be divided.

It may be here explained that by "rhinarium" is meant the naked and usually moist area of skin surrounding the openings of the nostrils ; that the antorbital glands are situated in front of the eye and open on the cheek; where these are large there is often a depression in the skull for their reception, in front of the orbit termed the antorbital fossa. 


\section{Key of the South African Subfamilies.}

$A$. Horns in the male sex only.

a. Larger animals from $2 \mathrm{ft} .6$ and upwards at the shoulder, with large rhinarium and no antorbital glands; horns generally ringed and curved forwards...............

b. Smaller from $2 \mathrm{ft}$. and downwards at the shoulder, rhinarium present or absent, horns short, straight and usually ringed only at the base...............................

Cervicaprinae, p. 183.

Neotraginae, p. 165.

$B$. Horns present or absent in the female.

c. Horns never ringed or knotted, usually spirally twisted with an anterior ridge, rhinarium large...............................

d. Horns lyrate and ringed, rhinarium much reduced, muzzle hairy, antorbital glands present or absent ............................

$e$. Horns short and straight, rhinarium well developed, antorbital gland opening along a narrow, naked line

Tragelaphinae, p. 229.

Antilopinae, p. 202.

Cephalophinae, p. 156.

C. Horns always present in both sexes.

f. Horns medium, lyrate or doubly twisted, antorbital gland small, rhinarium large, nostrils large and valvular

Bubalinae, p. 128.

$g$. Horns long, exceeding the length of the head, no antorbital glands, rhinarium reduced

Hippotraginae, p. 214.

h. Horns round or angulate, never knotted or ringed, rhinarium very large, nostrils lateral, no antorbital glands................

Bovinae, p. 252.

\section{Subfarnily BUBALINAE.}

Antelopes usually of large size with, as a rule, the body standing much higher at the withers than at the rump; the antorbital glands are small, the nostrils are large and valvular with a welldeveloped rhinarium, tail long and tufted, false hoofs large, two mammae, horns present in both sexes, of median length and rather varying shape. 


\section{Key of the South African Genera.}
a. With elongated heads and doubly curved horns
b. With normal faces and lyrate horns
Bubalis, p. 129.
c. With tufted faces and maned necks, horns with
expanded bases
Damaliscus, p. 137.
Connochaetes, p. 147.

\section{Genus BUBALIS.}

Bubalis, Lichtenstein, Mag. nat. Freund. Berl. vi,

Type.

p. 154 (1814) ...................................... b. buselaphus.

Alcelaphus, Blainville, Bull. Soc. Philom. p. 75

Damalis (gen.) and Acronotus (subgen.) H. Smith,

Griff. Anin. Kingd. iv, pp. 343, 345 (1827) …..... B. buselaphus.

Animals of considerable size characterised by their great height at the withers as compared with that at the rump; head long and narrow with a semilunate bare space above the nostrils, which are approximated and lined with stiff bristles; antorbital gland small ; false hoofs present; no knee brushes; tail long, reaching below the hocks; two mammae.

Horns present in both sexes, of moderate length, ringed and doubly curved, the tips posteriorly directed and the bases approximated.

Skull with the frontals produced upwards and backwards to form a long support to the horns, with no supra-orbital pits or lachrymal vacuities, but with a shallow fossa for the reception of the antorbital gland in front of the eye.

This genus contains the hartebeests, of which two species occur within the limits of South Africa. In addition to these there are known to science seven other species from other parts of Africa and Arabia. These are:

Bubalis buselaphus (Pallas), from North Africa and Arabia.

", major (Blyth), from West Africa.

" tora (Gray), from Northern Abyssinia and Upper Nubia.

" swaynei (P. L. Sclater), from Somaliland and Shoa.

" cokei (Gunther), from British and German East Africa.

" jacksoni (Thomas,) from Uganda and Central Africa.

" neumanni, Rothschild, from the neighbourhood of Lake Rudolf. 
In addition to these fossil species have been recorded from the Pliocene beds of India and the Pleistocene beds of Algeria.

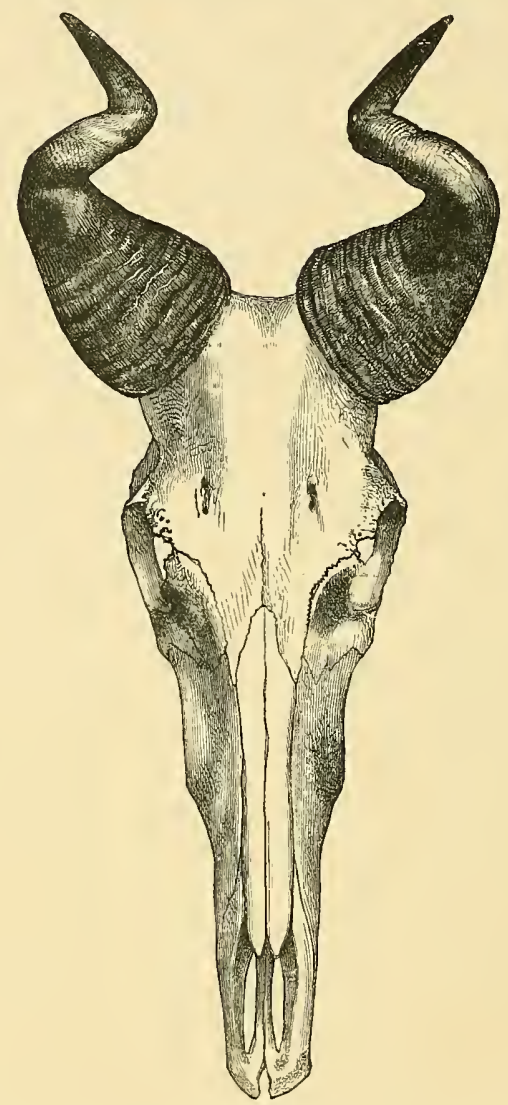

Fig. 38.-Skull and horns of Bubalis lichtensteini o (Proc. Zool. Soc.).

Key of the South African Species.

a. Colour dark fulvous with marked black blazes on face, front of shoulders and hips; horn pedicel extremely elongated, horns forming a $\mathrm{V}$ when viewed in front ... 乙. Colour much lighter with no marked black blazes; horn pedicel very short and thick; horns curved in towards one another before the final backward twist

B. caama, p. 131.

B. lichtensteini, p. 134 


\section{Bubalis caama. The Red Hartebeest.}

Antilope bubalis, apud Schreber, Säugeth. pl. cclxxvii (1787) [nec Pallas].

Antilope dorcas, apud Thunberg, Mem. Acad. Petersb. iii, p. 316 (1811) [nec Linn.].

Antilope caama, G. Cuvier, Dict. Sci. Nat. ii, p. 242 (1816).

Damalis (Acronotus) caama, Smuts, Enum. Mamm. Cap.p. 88 (1832) ; A. Smith, S. Afr. Quart. Journ. ii, p. 221 (1834).

Bubalis caama, Sundevall, K. Vet. Akad. Handl. Stockholm, 1844, p. 208 (1846); Selous, Proc. Zool. Soc. 1893, p. 1 [hybrid with Sassaby] ; P. L. Sclater and O. Thomas Bk. Antelopes i, p. 33, pl. iv (1894); Lorenz, Ann. k7. Hofmus. ix, notiz. p. 59 (1894); [Orange Free State]; Rendall, Proc. Zool. Soc. 1895, p. 362 [Transvaal].

Bubalus caama, A. Smit7, Illustr. Zool. S. Afr. Mamm. pl. xxx. (1840). Alcelaphus caama, Layard, Cat. Mamm. S. Afr. Mus. p. 76 (1861); Buckley, Proc. Zool. Soc. 1876, pp. 285, 292 ; id. ibid. 1877, p. 454 [distribution] ; Selous, Proc. Zool. Soc. 1881, p. 763 [distribution].

Literature.-Tachard (1686), p. 104, short notice; Kolben (1731), ii, p. 126, described under name of the "Hart"; Sparrman, Swedish Acad. Trans. xl. (1779), p. 151, pl. v, first accurately describes the Hartebeest of South Africa; Buffon (1782). Suppl. vi, p. 135, figure from Allamand, to whom a description and skin were sent from the Cape by Colonel Gordon, under the name of the Caama or Bubale; Sparrman (1785), i, p. 137, ii, pp. 12, 215, pl. i, fig. 1, met with the Hartebeest several times during his journey, and gives a general account of it; Paterson (1789), p. 81, description under name of Capra dorcas in Uitenhage; Thunberg (1795), i, p. 145, description as Capra dorcas of a specimen obtained at Groenekloof close to Cape Town; Barrow (1801), i, p. 359, still at Groenekloof ; Lichtenstein (1812), ii, p. 23, recorded as plentiful in Aberdeen in 1804; Burchell (1822), i, p. 420, ii, p. 81, numerous in Hanover and other northern Karoo districts ; Harris (1838), p. 142, in the Marico district of the Transvaal ; id. (1840), figured on pl. vii ; Cumming (1855), i, p. 118, shot in the Philipstown and Hopetown divisions ; Grout (1863), p. 303, native names and habits in Natal ; Holub (1882), i, p. 267, records great herds near Mafeking in 1873 ; Theal (1888), i, p. 51, notes that it was abundant close to Cape Town in 1652 in Van Riebeck's time; Nicolls and Eglington (1892), p. 45, pl. iv, fig. 13, description, distribution and habits; Bryden (1893), pp. 387, 505, habits and distribution; Ward (1896), p. 65, horn measurements ; Bryden (1897), p. 225, chapter on hunting ; Bryden (1899a), p. 150, account of habits and distribution.

Vernacular Names.-Hartebeest of the Dutch and English Colonists; Kaama of the Hottentots (Smuts) and Bechuanas (Bryden); Ixama of Amaxosa (Stanford); Indhluzele of Zulus (Stanford); 'Ama ingama of Makalakas and Masawas (Selous). 
Description.-Form somewhat ungainly owing to the great height at the shoulders as compared with the croup; general colour a rich sienna brown with black or nearly black blazes on the front part of the face, somewhat interrupted between the eyes, on the occiput between the horns and ears continued as a narrow line down the ridge of the neck, on the shoulder continued down the front of the legs and on the thighs; round the rump and along the belly much paler, almost white.

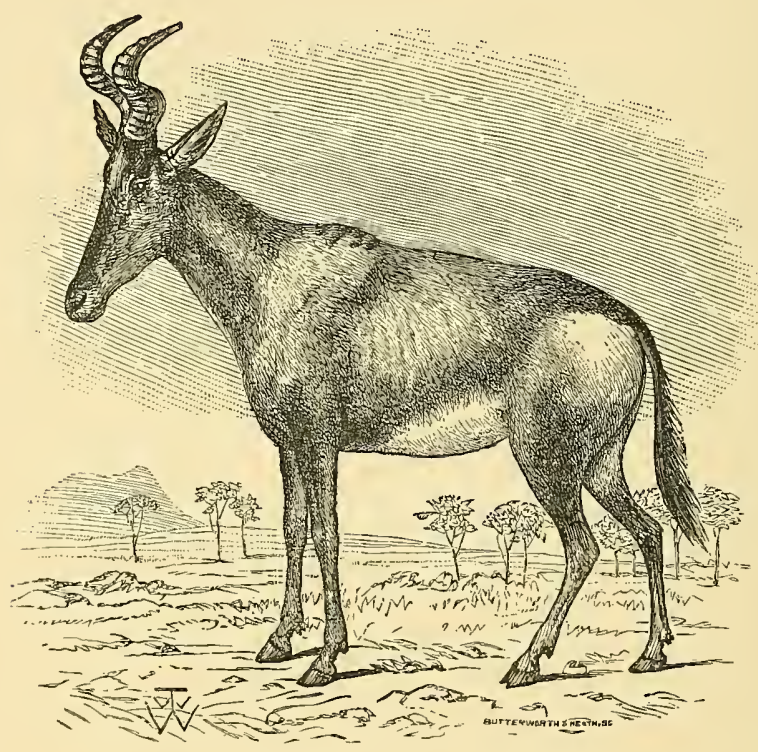

FIG. 39.-The Red Hartebeest (Bubalis caama). (Flower and Lydekker.)

Face very long and narrow; nose slit-shaped with a semi-lunar rhinarium above it; a rough tuft of hair covers the opening of the antorbital gland, often agglutinated by the waxy secretion; ears long and pointed, with a covering of white hairs inside; tail long with a number of long black hairs commencing close to the root directed posteriorly to form a compressed fringe.

Female of the same size as the male but paler in colour; the young are also like the female, with no sign of the black patches.

Horns elevated on a bony projection of the skull, black, ringed, nearly circular in section at the base, the basal third directed 
slightly outwards, the middle third slightly inwards and forwards, the distal third horizontally backwards forming nearly a right angle with the middle third; horns of the female of the same shape but much more slender. Skull with the frontal portion very narrow and backwardly produced.

Dimensions. - From a mounted male; head and body measured along the curves from the nose to the root of the tail $7 \mathrm{ft} .9$; tail with hairs 22, without, 17 ; height at shoulder $3 \mathrm{ft} .11$; ear from notch 7.0 ; from ear opening to nose-tip 17.5 ; skull length 16 , breadth $5 \cdot 4$; horns (measured along the front curve) of the male 20 , of the female 19 ; record according to Ward 25.

Distribution.-The hartebeest was formerly found all over the Colony, and was common in the immediate neighbourhood of Cape Town, as is mentioned in Van Riebeck's journal quoted in Theal's History; at the end of the last century it still survived at Groenekloof about 30 miles north of Cape Town, and Sparrman and other travellers met with it in Caledon and on the Zwartkops River near Port Elizabeth. On the karoo near Beaufort West they are said to have lingered till 1864.

At the present day there are still a few surviving in the deserts of Namaqualand and Kenhardt south of the Orange River, and north of this they are fairly abundant in Gordonia and Griqualand West and along the borders of the Kalahari as far as the lake Ngami region.

The hartebeest is still found, though rarely, in Basutoland, the Orange Free State and the Eastern Transvaal; in Natal a few are preserved on certain of the upland farms ; they are also fairly abundant in parts of German South-west Africa.

This species of hartebeest barely reaches the confines of Matabeleland, and has never yet been recorded from north of the Zambesi.

The South African Museum possesses a fine mounted pair from Khama's Country (Bechuanaland), shot by Mr. Selous in 1885, and skulls and horns from Damaraland and from Boshoff in the Orange Free State.

History.-The hartebeest was known from the earliest times in South Africa, and is mentioned by Tachard and Kolben though the descriptions are hardly recognisable. Sparrman was the first to give a really adequate account of the animal, but both he and Buffon, who derived his information from a skin and a description sent by Colonel Gordon to Professor Allamand of Leyden, confused 
the animal with the allied bubale of North Africa, and it was no till 1816 that Baron George Cuvier showed that the South African hartebeest really was quite a distinct animal.

Habits.-The hartebeest is found usually in open, somewhat desert country in small herds of about ten individuals; it is wary and suspicious, but of a very curious disposition, frequently turning during flight to gaze at its pursuer and so falling an easy prey to the marksman; its pace though without the appearance of speed is very great, and it is exceeded in this respect only by the sassaby among South African antelopes. In addition to man the hartebeest finds a constant enemy in lions and wild dogs.

During the breeding season the males fight fiercely on their knees with their horns, according to Harris; only one calf is produced at birth.

Like most of the larger South African antelopes the hartebeest suffers a good deal from the larvae of bot-flies, which are hatched in the nasal and even the frontal cavities of the skull of the animal, and which it endeavours in vain to get rid of by constant blowings and sneezings.

The flesh is dry and rather tasteless, but it is much used for the manufacture of biltong.

Mr. Selous has described the skull of an individual which he regards as a natural hybrid between a bartebeest and a sassaby; the animal was shot near Tati in Southern Matabeleland, and though the skull resembles in most respects that of the hartebeest, the horns are distinctly intermediate in character (see fig. 43, p. 145).

\section{Bubalis lichtensteini. Lichtenstein's Hartebeest.}

Antilope lichtensteinii, Peters, Mitth. Ges. nat. Fr. (1849) ; id Reise Mozamb. Säugeth. p. 190, pls. xliii, xliv (1852).

Bubalis lichtensteini, Temminck, Esq. Zool. Guin. p. 195 (1853); Bartley, Proc. Zool. Soc. 1894, p. 132 [Beira district]; P. L. Sclater and Thomas, Bk. Antelopes i, p. 45, pl. v, \& figs. $6 \mathrm{a}$ and b [skulls of of and o ] (1894).

Alcelaphus lichtensteini, Buckley, Proc. Zool. Soc. 1877, p. 454 [distribution]; Selous, Proc. Zool. Soc. 1881, p. 763 [distribution].

Literature.-Nicolls and Eglington (1892) pl. iv, fig. 14, p. 46, description and distribution; Selous (1893) p. 190, note on a specimen shot on the Sabi River in south Mashonaland, now in the South African Museum; Millais (1895) pp. 121, 123, habits, nomenclature, and distribution in south- 
east Mashonaland; Ward (1896) p. 76, horn measurements ; Kirby (1899) p. 333, distribution in the Beira country; Selous and Rendall (1899a) p. 160, range and habits.

Vernacular Nayes.-Moff-hartebeest of the Transvaal Boers (Millais); Vacea de Mato (i.e., wood cow) of the Portuguese (Peters) ; Konze of Masubias, Inkulanondo of Mashonas (Selous).

Description.-Form and size much as in the common hartebeest; general colour above a bright rufous, brighter than in the other species, paler on the sides, nearly white below; face a little

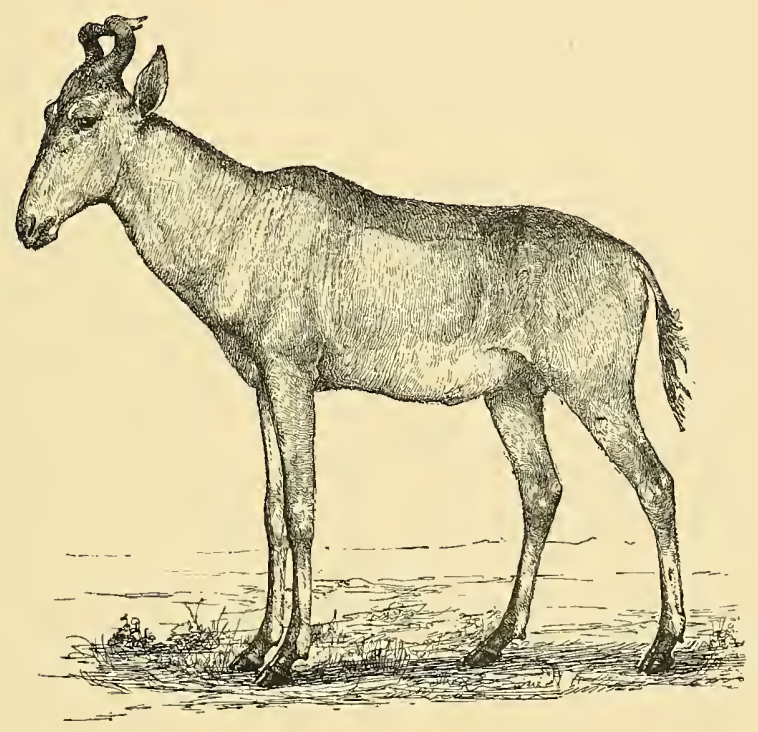

FIG. 40.-Lichtenstein's Hartebeest (Bubalis lichtensteini).

darker along the line of the nose but not black, chin black, upper forehead and occiput between the horns and ears also black, nose and ears as in the other species; no antorbital tuft, no black patch on the shoulder, though sometimes a patch of grey shows itself a few inches behind the shoulders; along the front of the legs both fore and hind, a well-marked line of black extending to the hoofs; rump pale, almost white contrasting with the back; tail with the proximal quarter with smooth short hairs, beyond this point begins the posteriorly directed black fringe present in the other species. 
Female slightly smaller and paler and with two mammae, in other respects like the male.

Horns (fig. 38, p. 130) very much flatter at the base and not set so high as in the common species; the basal thirds directed outwards, the middle thirds strongly inwards again, the terminal thirds horizontally backwards and parallel to one another, only the basal flattened portion is conspicuously ringed or rather furrowed.

Skull without the marked frontal elevation characteristic of B. caama, but the front part of the muzzle even more elongated; males with a conspicuous boss in the middle of the forehead between the horn bases and the orbits.

Dimensions.-From a mounted specimen in the South African Museum; head and body $7 \mathrm{ft} .8$; tail without terminal hairs 17 , with 20 ; height at shoulders $4 \mathrm{ft} .3$; ear from notch $7 \cdot 5$; from ear opening to nose-tip $17 \cdot 0$; skull length 16 ; breadth $6 \cdot 75$; average horns of male 16.5 ; of female 13.0 ; record according to Ward $21 \cdot 0$.

Distribution.-Lichtenstein's hartebeest is only found in the north-eastern part of South Africa, from the Nuanetsi and Sabi Rivers of South-eastern Mashonaland northwards through the Pungwe Valley to the Zambesi; north of this river it extends its range to about opposite Zanzibar, to Nyasaland, and to the Barotse country beyond the Victoria Falls.

The South African Museum possesses a mounted pair shot by Mr. Selous on the Sabi River in South-east Mashonaland in 1885, a skin and skull from Nyasaland and several skulls from the Beira district.

History. - The present species was first brought to the notice of naturalists by the celebrated German savant Dr. W. Peters, who made extensive journeys in Mozambique between the years 1842-48; he first discovered the animal in the Portuguese provinces of Sena, Tette and Boror, and dedicated it to his predecessor in the keepership of the Berlin Museum, Lichtenstein, who had also travelled in South Africa. Since that time it has been found to extend a good deal further south by Selous, Barkly and Millais, and may even perhaps reach as far as Delagoa Bay.

Habits.-There is little recorded concerning the habits of this hartebeest, it seems to be found in small herds on the grassy plains in the open, often consorting with waterbuck, impala, and other larger antelopes; Millais relates that it is fond of making a lair for itself in reeds or bushes from which it is frequently ousted by the more quarrelsome sable or gnu. Its pace is good when 
pressed; it drinks morning and evening, and is very partial to a mud bath.

\section{Genus DAMALISCUS.}

Damalis, apud Gray, Ann. Mag. N. H. (1) xviii, p. 233

Type.

(1846) [nec H. Smith]

D. lunatus.

Damaliscus, $P$. L. Sclater and Thomas, Bk. Antelopes

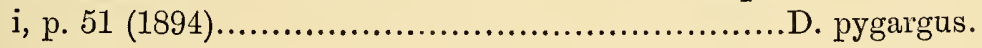

Antelopes agreeing in most characters with the preceding genus, but with more normally shaped faces, the frontal bones not being upwardly produced to form a support for the horns, so that when the skull and horns are viewed from above the parietal region is easily visible, which is not the case in Bubalis.

Horns nearly equally developed in both sexes, with a simple or slightly lyrate curve, but not abruptly doubly curved as in Bubalis.

The range of this genus is confined to Africa, south of the Sahara; in addition to the three species below described the following are known :-

D. hunteri (Scl.), Hunter's antelope from South Somaliland.

D. korrigum (Ogilb.), the Korrigum from West Africa.

D. tiang (Heugl.), the Tiang from the Upper Nile Valley.

D. jimela (Matsch.), the Topi from Uganda and East Africa.

Key of the South African Species.

$A$. Face white, horns forming an acute $V$.

a. A very distinct white rump; horns black

D. pygargus, p. 137.

b. Rump not white though sometimes a little paler

than the rest of the body; horns pale............

$B$. Face dark, almost black; horns wide-spreading,

forming an obtuse $\mathrm{V}$

D. albifrons, p. 141.

D. lunatus, p. 144.

\section{Damaliscus pygargus. The Bontebor.}

Antilope dorcas, Pallas, Miscell. Zool. p. 6 (1766) [nec Linn.].

Antilope pygarga, Pallas, Spic. Zool. i, p. 10 (1767), xii, p. 15 (1777);

Smuts, Enum. Mamm. Cap. p. 73 (1832) [in part].

Antilope maculata, Thunberg, Mem. Acad. Petersb. iii, p. 315 (1811).

Antilope personata, Wood, Zool. Journ. iv, p. 524 (1829). 
Gazella pygarga, A. Smith, S. Afr. Quart. Jou'n. ii, p. 189 (1834) [in part].

Damalis pygarga, Layard, Cat. Mamm. S. Afr. Mus. p. 77 (1861) ; id., Proc. Zool. Soc. 1871, p. 625.

Damaliseus pygargus, P. L. Sclater and O. Thomas, Bk. Antelopes i, p. 73, pl. viii \& fig. 10 [woodcut of animal] (1895).

Literature.-Masson (1776), p. 287, note on Bontebok's occurrence near the Kaffir Kuils River in Riversdale; Sparrman (1785) i, p. 137, ii, p. 237, account of the occurrence of the Bontebok in Caledon; Paterson (1790), pp. 12, 21, numerous in Caledon and Swellendam; Barrow (1801), p. 307, formerly much more abundant in Swellendam, now reduced to troops of twelve to twenty; Moodie (1835), p. 282, then confined to a district between the Breede and the Duivenhoek Rivers in Swellendam; Harris (1838), p. 308, though accurately noticing distinctions from the Blesbok, describes the Bontebok as occurring in considerable numbers in the Orange Free State; id. (1840), pl. xvii; Gray (1850), p. 21, pl. xx, fig. 3 [juv.] pl. xxii, figs. 2, 3 [adult], figured from life; Nicolls and Eglington (1892), p. 32 , pl. vii, fig. 27, description and distribution; Ward (1896), p. 85, horn measurements; Bryden (1897), p. 273, general account; Selous (1899), p. 175 , range and habits.

Vernacular Navie.-The Bonte-bok (i.e., pied goat) of the Dutch Colonists.

Description.-General colour a rich brown, palest on the shoulders and saddle, darkest, almost a purplish black, on the sides and upper parts of the fore and hind limbs; face white from between the base of the horns to the nose, the patch above the forehead much narrower than below the level of the eyes, where it suddenly expands; ears white inside with a white patch at the base; below pure white sharply marked off from the dark sides, the colour extending up between the hind legs to form a conspicuous pure white rump patch continued round the root of the tail; forelimbs in front, above and below the "knees" dark, almost black, inside and around the "knees" white; hind limbs outside as far as the hocks and a small patch on the front part of the toes dark, rest white.

Tail reaching halfway to the hocks, basal half covered with short white hairs, posterior half with the usual backwardly directed fringe of long black hairs; no suborbital brushes; sexes alike.

The young animal at the time of birth shows no traces of the white face or rump, but is fawn coloured throughout and slightly paler below.

Horns with twelve or thirteen transverse ridges prominent in 
front, much less noticeable behind, the bases somewhat compressed; the basal two thirds curved gently outwards and backwards, the terminal third smooth and slightly recurved inwards and forwards, colour quite black. Skull long and slender with slight depressions in front of the orbits for the reception of the antorbital glands.

Dimensions.- Of a mounted male, head and body $5 \mathrm{ft.} 2$; tail without $9 \cdot 5$, with terminal hairs $18 \cdot 0$; height at shoulders 37 ,

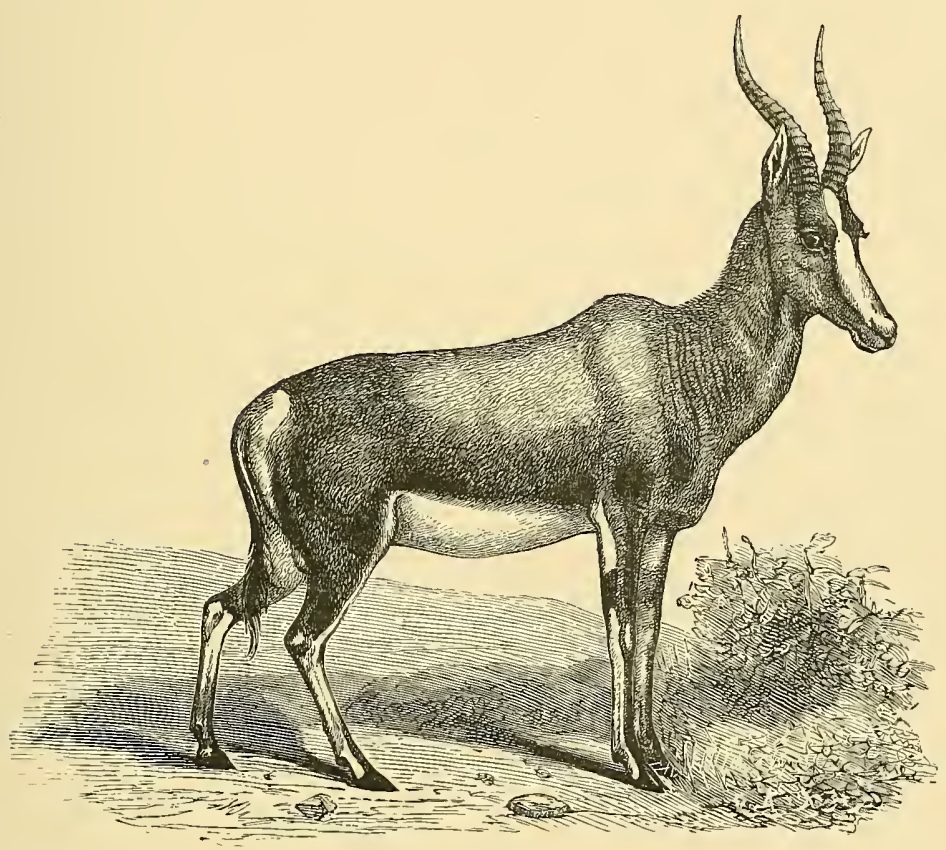

FIG. 41.-The Bontebok (Damaliscus pygargus).

(Book of Antelopes.)

ear 5.5; from ear opening to nose-tip 13 ; Harris gives the height at 46 , but this, I think, must be an exaggeration, or due to a different system of measurement.

Horns 14 to 15 , the record according to Ward being $16 \frac{3}{8}$. Skull length $12 \cdot 8$, breadth $5 \cdot 05$.

Distribution. - The bontebok is now found only on two farms situated on what is known as the Strand Veld between the village of Bredasdorp and Cape Agulhas, the extreme southern point of Africa. 
These farms are named "Nachtvacht" and "Zeekoe Vley" and are the property of Mr. J. D. Albertyn and Dr. Albertyn respectively; formerly they belonged to Messrs. vau der Byl and van Breda, to whom, together with the present owners, is due the credit of having preserved this interesting species from complete extinction since the early part of the century.

Formerly the bontebok was somewhat more widely spread throughout the south-western corner of the Colony. Sparrman mentioned seeing a herd near the Bot River in Caledon and Smuts notes it from the Breede River in Swellendam, but Harris, although he was the first to clearly point out the difference between this species and the blesbok, was, I believe, in error in asserting that the former was found in vast numbers on the plains of the interior, and in this he has been followed by nearly all subsequent writers. It is a remarkable fact, moreover, that no one has subsequently found the bontebok in the interior either in the Orange Free State or in the eastern part of the Colony, while the blesbok still remains preserved on several farms throughout the Orange Free State and the Transvaal.

The herds now preserved are said to number about 300 individuals, and the South African Museum possesses a good series of examples all from Mr. Albertyn's farm at Nachtvacht.

History.-The bontebok or pied goat was well known to the earlier Dutch settlers, and is mentioned by nearly all the travellers at the end of the 18th century; it first became known to European naturalists through the description of the celebrated Russian naturalist, Pallas, who gave a very good and recognisable account of it, but compared it with the "Dorcas" of Aelian, now identified as one of the gazelles. This mistake he subsequently corrected, and selected for it the very appropriate name of Antilope pygarga, which it has since borne.

Even in those times the bontebok was becoming increasingly rare, and now it may be said to be quite extinct in a feral state, although preserved as above-mentioned on certain farms in the south-western part of the Colony.

Habits. - The bonteboks on the farms, where they are preserved in large camps or runs enclosed in a wire fence, roam about in herds of from eight to fifteen individuals; their best pace is a somewhat lumbering canter, which, though not appearing to be rapid, is enough to require a very good horse to overtake them; they run in single file usually upwind with their noses down near the ground. 
Their food consists of the herbage of the veld which in the Bredasdorp division is composed of rhenoster bush, coarse grass and heather.

The young are born in the latter end of August or the beginning of September, but the time varies a good deal. The period of gestation appears to be from nine to ten months. The young are easily found and caught, lying either under a bush or even in the open, but are very difficult to rear even with cows' milk.

They are wary and suspicious and not easily approached.

\section{Damaliscus albifrons. The Blesbor.}

Antilope albifrons, Burchell, Travels ii, p. 335 (1824).

Damalis albifrons, Layard, Cat. Mamm. S. Afr. Mus. p. 77 (1861).

Alcelaphus albifrons, Buckley, Proc. Zool. Soc. 1876, pp. 286, 292.

Damaliscus albifrons, P. L. Sclater and O. Thomas, Bk. of Antelopes i, p. 79, pl. ix, \& fig. 11 [woodeut of animal] (1895).

Literature.-Harris (1838), p. 287, saw great herds on the plains of the Orange Free State; id. (1840), figured on pl. xxi; Gray (1850), p. 22, pl. xxii, fig. 1; Cumming (1855), i, pp. 93, 179, account of distribution and habits; Holub (1882), p. 267, found in great herds near Mafeking in 1873 ; Nicolls and Eglington (1892), p. 31, pl. iii, fig. 9, description and distribution ; Bryden (1893), p. 508, on the distribution; Millais (1895), pp. 45 and 235, sketches and notes of a herd preserved in the Transvaal ; Ward (1896), p. 83, horn measurements; Bryden (1899), p. 183, range and habits.

Vernacular Names.-Blesboli of the Dutch; Ilinqua of Amaxosa (Stanford) ; None or Nunni of the Bechuanas (Harris and Bryden).

Description.-Closely resembling $D$. pygargus in most respects, except that the general colour is rather more reddish and without the purplish gloss; the white blaze on the face is sometimes divided by a narrow transverse band between the eyes; the rump is not white, a very small area round the base of the tail being paler than the rest of the animal ; ears almost white; outside of the fore and hind limbs brown, not white below the knees.

In a young female with horns 12 inches in length the body generally is a light greyish brown colour and shows no black markings ; the white, however, on the face, belly and insides of the legs is all well marked. Skull and horns closely resembling that of its ally the bontebok, except that the horns are pale in colour and not black; this is specially the case with the prominent rings which are almost white. 
Dimensions.-From a mounted male; head and body 5 ft. 4 ; tail 6.5 , with hairs 12 ; height at shoulder $3 \mathrm{ft} .2$; ears $5 \cdot 0$, from ear opening to nose-tip $12 \cdot 0$.

The skull of a male measures in extreme length 12.50 , from the premaxillae to the condyle 12.0 , in breadth 4.90 ; the horns average between 15 and 16; Ward records a pair in the possession of Sir E. Loder measuring $18 \cdot 5$.

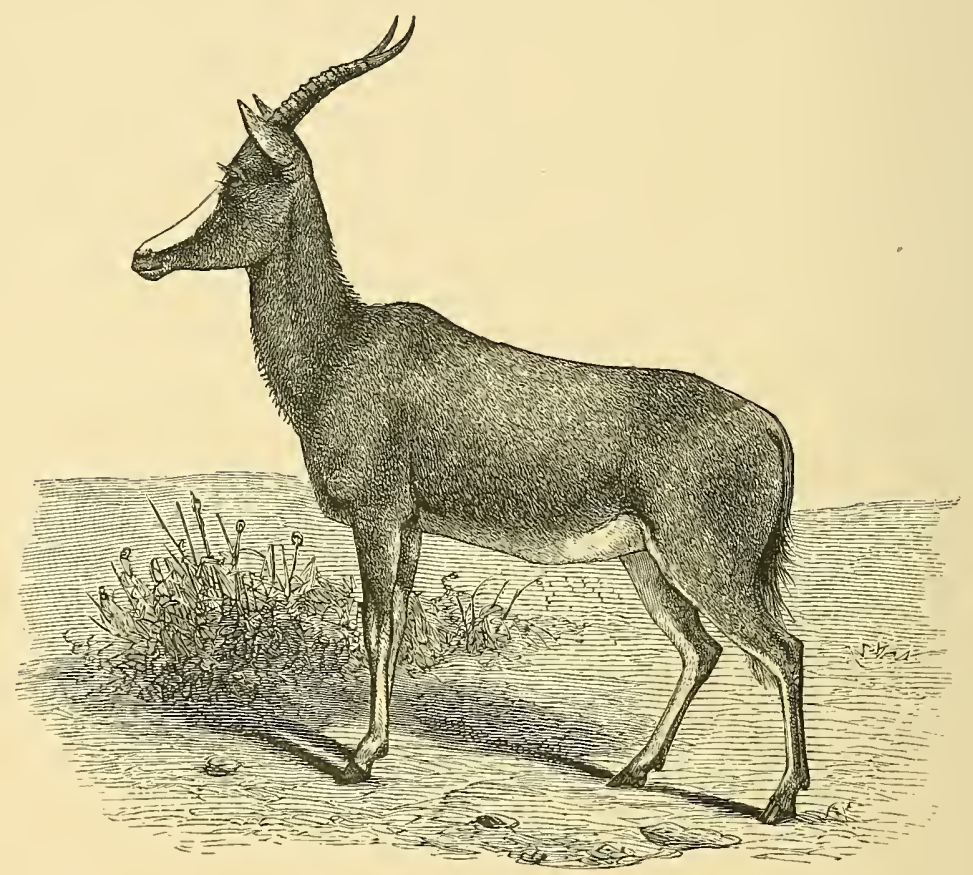

FIG. 42.-The Blesbok (Damaliscus albifrons).

(Book of Antelopes.)

Distribution.-The blesbok was formerly found in very large numbers on the north-eastern plains of the Colony extending northwards over the high veld of the Orange Free State, Transvaal and eastern portion of Bechuanaland; it does not appear to reach Matabeleland or Mashonaland; Harris in 1838 found it abundant on Bontebok flats in the present Queenstown and Tarka districts. Cumming, a few years later, notes that it was rare south of the Orange Piver but very abundant further north on the Griqualand 
West and Orange Free State borders; even as late as 1873 Holub records large herds in the neighbourhood of Mafeking in Bechuanaland. At the present day a herd is preserved in the Steynsburg division of the Colony whence the South African Museum has obtained a fine male specimen. On a good number of farms on the high veld of the Orange Free State, the Transvaal and Bechuanaland, similar herds are found, almost invariably preserved in large fenced enclosures or camps.

The blesbok never seems to have extended north of the Limpopo.

History.-Although vaguely referred to by Sparrman and named by Burchell, the blesbok was never properly discriminated from the bontebok till Harris' time, and even his account is not at all clear, as he speaks of bonteboks in the eastern part of the Colony and beyond the Orange River where I feel certain they never existed. The fact seems to be that he did not discover the real distinctions between the two animals until the end of his huntingtrip when he went to the true bontebok country in Bredasdorp. His error, as I believe it to be, of believing the bonteboks were to be found with the blesboks in the north and east of the Colony has been followed by every other writer since, ${ }^{1}$ but there has never been the slightest independent evidence for this assertion, so tar as I have been able to discover.

Habits.-The blesbok seems to resemble the bontebok in its habits, being found on the open plains of the high veld in smal parties; its pace is described as being a heavy rolling canter, considerably exceeding that of the springbok. Some years back, before the enclosure of the country, it used to migrate southwards across the Vaal river in winter and back to the north in summer, where it calved in about November. When disturbed it almost invariably makes off up-wind, carrying its head low with the nose almost touching the ground. It is suspicious and wary, and difficult to approach especially when the grass is short.

1 Except Mr. Selous, who discusses the question in "Great and Small Game of Africa," p. 175. 


\section{Damaliscus lunatus. The Sassaby.}

Antilope lunata, Burchell, Travels ii, p. 334 (1824).

Damalis lunata, H. Smith, Griff. Cuv. An. Kingd.iv, p. 352. [plate], v, p. 364 (1827); Smuts, Enum. Mamm. Cap. p. 89 (1832); A. Smith, S. Afr. Quart. Journ. ii, p. 222 (1834); Layard, Cat. Mamm. S. Afr. Mus. p. 77 (1861).

Bubalus lunatus, A. Smith, Illustr. Zool. S. Afr. Mamm. pl. xxxi (1841). Alcelaphus lunatus, Buckley, Proc. Zool. Soc. 1876, p. 285 [distribution]; Selous, Proc. Zool. Soc. 1881, p. 764.

Damaliscus lunatus, P. L. Sclater and Thomas, Bk. of Antelopes, i, p. 85, pl. x, \& fig. 12 [skull of hybrid with Hartebeest] (1895).

Literature.-Daniell (1820), figured but not described on pl. 18; Harris (1838), pp. 68, 142, shot the Sassaby in Bechuanaland and in the Western Transvaal; id. (1840), figured on pl. viii. ; Cumming (1855), i, pp. 135, ¿46, shot Sassaby in Griqualand West and in northern Bechuanaland; Nicolls and Eglington (1892), p. 33, pl. vi, fig. 19, description, distribution and habits; Bryden (1893), p. 506, account of distribution; Kirby (1896), p. 540, native names and habits in the Eastern Transvaal; Ward (1896), p. 81, holn measurements ; Gibbons (1897), p. 395, occurrence in Barotseland; Kirby (1899), p. 334, occurrence in the Beira-Zambesi country; Kirby (1899a), p. 190, range and habits.

Vernacular Names.-The Bastard Hartebeest or Zulu Hartebeest of the Boers; Tsessebe of the Bechuanas (whence the English name); Incolomo, Incomazan of the Matebele ; Inkweko of Masubias ; Unchuru of the Makubas; Inyundo of the Makalakas; Lechu of Masaras (Selous); 'Mzansi of Swazis ; Igalowana of Basutos (Kirby).

Description.-General form hartebeest-like, higher at the withers and falling off considerably behind; colour a rich chocolate brown with somewhat irridescent satiny reflections; darker, almost black patches on the face extending back between the horns to the occiput, on the shoulder extending down the outside of the legs and forming a ring above the "knees" and on the haunches extending down and round the leg at the hocks; rhinarium semilunate as in the hartebeest; suborbital gland opening marked by a patch of bare skin; ears long and pointed, covered inside with white hairs and outside with brown which becomes quite black at the tips. Rump and posterior part of the belly paler than the back but not white; tail not reaching the hocks; proximal portion like the body, distal portion with a posteriorly directed fringe of long black hairs as in the hartebeest.

Female resembling the male, but rather more slender: with two mammae. 
The young are of a bright yellowish red colour.

Horns with the basal two thirds ringed and forming a very wide angle, the distal third smooth and curved slightly inwards and forwards ; horns of the female only differing from those of the male in being a little slighter.

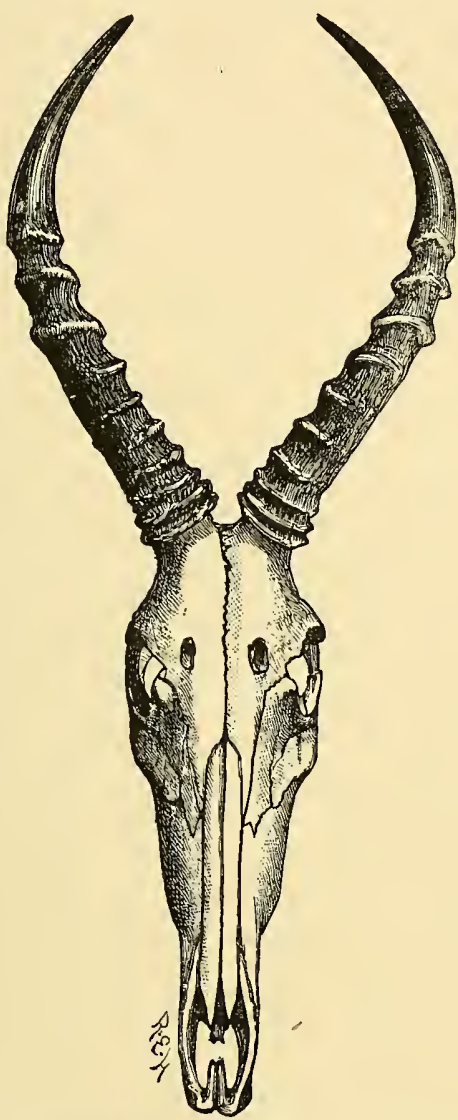

FIG. 43.- Skull and horns of a supposed hybrid between the Red Hartebeest and the Sassaby (Proc. Zool. Soc.).

The supposed hybrid between this and the hartebeest mentioned by Mr. Selous has been noticed in the account given of the latter animal.

Dimensions.-Of a mounted male, head and body $6 \mathrm{ft} .10$; tail 14 with, 19 without terminal hairs; height at shoulder $4 \mathrm{ft}$; ; ear $7 \cdot 0$; from ear opening to nose-tip $17 \cdot 5$. 
Weight, according to Ward, $300 \mathrm{lbs}$; horns of the above measured male 14.5 , of a female $13 \cdot 25$, record head from Mashonaland belonging to Sir J. Willoughby $15 \cdot 75$, according to Ward. A skull of a male measures 16.25 in extreme length and 6.5 in breadth.

Distribution.-The sassaby is found throughout Matebeleland and Mashonaland extending westward past Lake Ngami to Northern Ovampoland and south-eastwards into the low country of the Transvaal and Portuguese East Africa, perhaps reaching as far south as Swaziland. When first discovered it reached Bechuanaland and the North-western Transvaal but there it now seems to be extinct or exceedingly rare. It extends to the north of the Zambesi in the Barotse country, as recorded by Selous and Gibbons, but it does not seem to be found in Central Africa generally.

A good mounted pair in the South African Museum were shot by Mr. Selous in Mashonaland in 1882 .

History.-Although to Burchell must be assigned the credit of first describing the sassaby, it was apparently known some years previously, as on pl. 18 of William Daniell's illustrations it will be found figured under the name of "Sassyby a buck not hitherto described, from the Booschwana country." The original sketch for this plate was no doubt made by Samuel Daniell, the brother of William, who accompanied Truter and Somerville on their journey to Latakoo in Bechuanaland in 1801.

Burchell obtained the type specimen of the species on July 9, 1812, on the Makkwarin River between Kuruman and Litakoo in Bechuanaland, and named it Antilope lunata from the somewhat lunate shape of its horns; and the horns and frontlet of this specimen are still preserved in the British Museum; since that time it has become very much better known, the best accounts of its habits and distribution being those of Selous and Kirby referred to above.

Habits.-The sassaby is found in rather open flat country as a rule, never among the hills or in thick jungle, it is specially fond of a forest country interspersed with many open glades. In the Portuguese low country it appears to associate in small herds of from eight to ten individuals, but in Matabeleland many hundreds have been seen together. It is frequently accompanied by zebra and wildebeest.

Both Kirby and Selous state that the sassaby is the fleetest, toughest and most enduring of all South African antelopes, though the wildebeest and sable run it very close in this respect. 
The young are born from September till November, and run very swiftly from their earliest youth.

This antelope though very vigilant is rather stupid and easily shot; its flesh is good eating and becomes at times loaded with fat, which latter, however, has a disagreeable cloging taste to the palate.

\section{Genus CONNOCHAETES.}

Connochaetes, Lichtenstein, Mag. nat. Freund. Berl. vi, Type. p. $152(1814)$........................................ gnu.

Cemas, Oken, Lehrb. Naturgesch. iii, Zool. pt. ii, p. 727 (1816) .C. gnu.

Catoblepas, H. Smith, Griff. Cuv. Anim. K., iv, p. 366 (1827) .C. gnu.

Gorgon, Gray, Proc. Zool. Soc. 1850, p. 139 C. taurinus.

Size large; form somewhat thick and clumsy, head massive with a broad bristly muzzle; nostrils large, widely separated and hairy within; neck maned; mammae two in number.

Skull broad and heavy, not specially elongated, the ends of the premaxillae expanded.

Horns in both sexes without rings and with expanded bases, the proximal portion outwardly or downwardly directed, the distal portion upwardly directed at a sharp angle to the basal portion.

This genus is confined to southern and eastern Africa, and in addition to the two species described below contains the two following :-

C. johnstoni, Scl. from Nyasaland.

C. albojubatus, Thos. from East Africa.

Both these, however, are closely allied to the South African Blue Wildebeest, and are hardly separable except as geographical sub-species.

Key of the South African Species.

$A$. Tail white; hairs of facial tuft upwardly directed;

basal portion of the horns directed downwards ...... C. gnu, p. 148.

$B$. Tail black; hairs of facial tuft downwardly directed;

basal portion of horns directed outwards.

C. taurinus, p. 152. 


\section{Connochaetes gnu. The Black Wildebeest} or White-tailed GNu.

Bos gnou, Zimmermann, Spec. Zool. Geogr.p. 372 (1777); Thunberg, Mem. Acad. Petersb. iii, p. 318 (1811).

Catoblepas gnu, H. Smith, Griff. Cuv. An. Kingd. iv, p. 367, v. p. 368 (1827) ; Smuts, Enum. Mamm. Cap. p. 93 (1832); A. Smith, S. Afr. Quart. Journ. ii, p. 224 (1834) ; Buckley, Proc. Zool. Soc. 1876, pp. 286, 292 [distribution]; Blaauw, Proc. Zool. Soc. 1889, p. 2, figs. a.-d. [breeding and growth of horns].

Connochaetes gnu, Gray, Cat. Ung. Brit. Mus. p. 119 (1852) ; Layard, Cat. Mamm. S. Afr. Mus. p. 76 (1861); P. L. Sclater and O. Thomas, Bk. Antelopes i, p. 111, pl. xii \& fig. 15 a.ee. [young animals and their horns] (1895).

Literature.-Allamand (1776) Histoire Naturelle du Gnou, du Grande Gerbe et de l'Hippopotame, Amsterdam, contains the earliest description of this animal; Buffon (1782) Suppl. vi, p. 89, early notices of the discovery and of the first individual brought to Europe ; Sparrman (1785), ii, pp. 141, 190, figure (pl. ii.), description and account of meeting the wildebeest in Somerset East; Barrow (1801), i, pp. 259, 261, met with this animal in Middelburg and discussed its affinities; Burchell (1822), i, p. 431, ii, p. 109, met with in Griqualand West and Hanover, and shows that it is a true antelope; Steedman (1835), p. 139, account of its habits in Cradock; Harris (1838), p. 34, account of habits on the Richmond plains, p. 262, note on its occurrence north of the Vaal River; id. (1840) figured on pl. i; Cumming (1855), i, p. 62, occurrence on the northern plains of the Colony in great abundance in 1843-4; Bryden (1889), p. 293, records its surviving in Victoria West; Nicolls and Eglington (1892), p. 48, pl. vii, fig. 25, description, distribution and habits; Millais (1895), pp. 219, 226, habits, distribution and sketches; Ward (1896), p. 92, horn measurements ; Bryden (1897), p. 252, general account; Bryden (1899a), p. 206, range and habits.

Vernacular Names.-Black Wildebeest or Zwart Wildebeest of the Colonists ; T'gnu of Hottentots (Smuts); Inxu of the Amaxosa (Stanford); Inkankone of Zulus (Drummond).

Description.-General form somewhat ox-like owing to the width of the face and the form of the horns; general colour rich chocolate brown somewhat darker about the face and neck especially in the male; very broad across the nose with large slit-like nostrils clothed within with white bristles, bordered above by a semi-lunar bare space: eyes surrounded by a few stray white bristles; opening of the suborbital gland concealed by a tuft of hairs; an upwardly directed patch of long black hair on the middle line of the face, similar patches on either side along the chin and throat and on the chest between the front legs; an upright stiff mane along the neck 
from between the horns to the shoulder, the longer middle hairs of this are black, the outer shorter hairs a yellowish white. Ears rather long, narrow, rounded and drooping, owing to the position of the horns; legs slender and well formed, with conspicuous false hoofs and narrow, well pointed true hoofs; tail long, reaching the hocks, the longer hairs nearly touching the ground, these long hairs begin close to the base of the tail, and are coloured white.

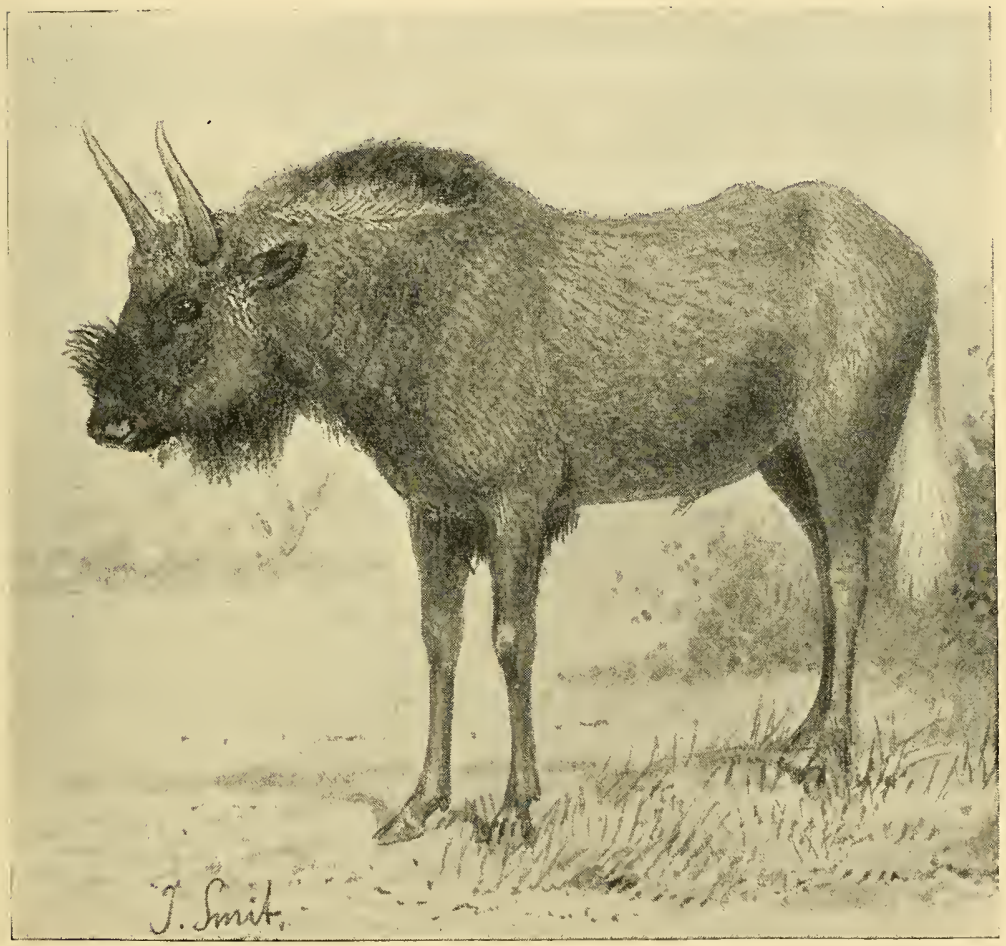

FIG. 44.-Young Black Wildebeest, eight months old. (Book of Antelopes.)

Female very similar, but more slenderly built, especially about the neck; udder with two mammae, not four as usually stated; this has been settled by a careful examination of both mounted and living specimens in South Africa and in the Zoological Society's Gardens in London. Buckley states that there is a. slight seasonal change from brown in summer to almost black in winter. 
Skull with the occipital portion somewhat lengthened to form a support for the very wide palms of the horns; premaxillae wide in front.

Horns without rings, the bases or palms very wide and thick, and in the old males rough with cross wrinkles, due apparently to splitting; from the bases the horns extend downwards and forwards over the eyes for about half their length, and then curving in an acute angle point directly upwards for the rest of their length. Horns of the female similar to those of the male, but smaller, and with their bases much less approximated.

Dimensions.-Of a mounted male; head and body along the curves 6 ft. 6 ; tail 18, with long hairs 33 ; height at shoulders $3 \mathrm{ft}$. 6 , of the corresponding female $3 \mathrm{ft}$.; ear 6.0 , from ear opening to nose tip $15 \cdot 0$.

Good horns of a male measure 25 along the outside curve, and 10 across the palm; of a female 21 and 5 respectively; the largest pair of horns in the South African Museum measure 27.25 and 10.5 , the record as given by Ward is $30 \frac{7}{8}$.

A skull of a male measures 15.5 in basal length, and 6.25 in extreme width.

Distribution.-The black wildebeest never extended northwards much beyond the Vaal River and the southern half of the Transvaal, and though formerly extremely abundant, especially on the high veld of the Orange Free State and northern part of the Colony, is now practically extinct in a true feral condition; small herds are preserved on some of the farms in the southern part of the Transvaal, and in the Orange Free State, where Millais met with them and sketched them, and whence the South African Museum possesses a mounted pair. South of the Orange River it is doubtless extinct; the last herd is said to have survived in the Victoria West district till a comparatively late date, and there is the skull of a male in the Museum, shot there about the year 1878. It is possible that a few black wildebeests may still be found in the Kalahari and Gordonia, and also in German South-west Africa.

Formerly, this antelope was found throughout all the interior districts of the Colony in great abundance. Sparrman records it from Somerset East in 1800; Pringle from Bedford 1820; Burchell from Hanover, and Harris from the plains of Richmond in the thirties.

History. - The black wildebeest must have been known to the Dutch settlers from the earliest part of the last century, but no 
mention of it in scientific literature occurs till 1776, when Allamand, a Dutch naturalist, described a living specimen brought to Holland and placed in the menagerie of the Prince of Orange. Buffon, a few years later, copied Allamand's account and gave additional information obtained by him through the Vicomte de Querhoent, and through Foster, who saw a living specimen at Cape Town about 1773.

On Buffon's description Zimmermann founded the specific name which it has since borne.

Harris and Millais give, perhaps, the best recent accounts of the habits of this animal.

Habits.-The wildebeest is an inhabitant of the open plains, associating in herds of varying numbers described as from 8 to 50 individuals; it was frequently found in company with ostriches and quaggas; at certain times of the year the very old males are found solitary. Their voice is described as a loud bellowing snort with a metallic ring in it, and to somewhat resemble the Hottentot name t'gnu.

Their pace is very considerable, but the advantages to be derived from this attribute are considerably diminished by their great curiosity and their extraordinary antics, which they display when disturbed; these consist of pawing the ground with their hoofs, tearing it up with their horns, striking sideways at one another, lashing round with their long tails, prancing and darting about in all dircctions; they are described at great length by nearly all observers, and can further be witnessed in the case of animals in captivity. It is possible that to a certain extent these antics may be die to their efforts to free themselves from the larva of a botfly (Aestrus sp.) which is invariably found in their nostrils and frontal sinus in great abundance. They frequently feed kneeling on the veld.

In the breeding season the males become very fierce, vicious and pugnacious, and the females after a period of gestation of 8 to $8 \frac{1}{2}$ months, produce a single calf usually about December; the mother suckles the calf for seven or eight months, but it commences to eat grass when about a week old.

In captivity the wildebeest does very well both in Europe and Africa, though the males are dangerous to meddle with; Mr. F. E. Blaauw has been very successful in acclimatising and breeding these animals in his park near Hilversum, in Holland, and he had reared in 1894 no less than sixteen young ones from a single pair purchased in 1886. 
An interesting feature of the development of the gnu is the growth of its horns; these at first are perfectly straight, upright and slightly divergent; as the animal grows the straight portion first formed gradually becomes the terminal portion, and the basal downwardly directed part is gradually formed; finally the wide palm is developed and these grow gradually together till they almost meet.

The white-tailed gnu forms the dexter supporter of the arms of the Colony of the Cape of Good Hope (see frontispiece), and it would be a thousand pities if so characteristic a form was allowed to become altogether extinct, as seems not unlikely to happen.

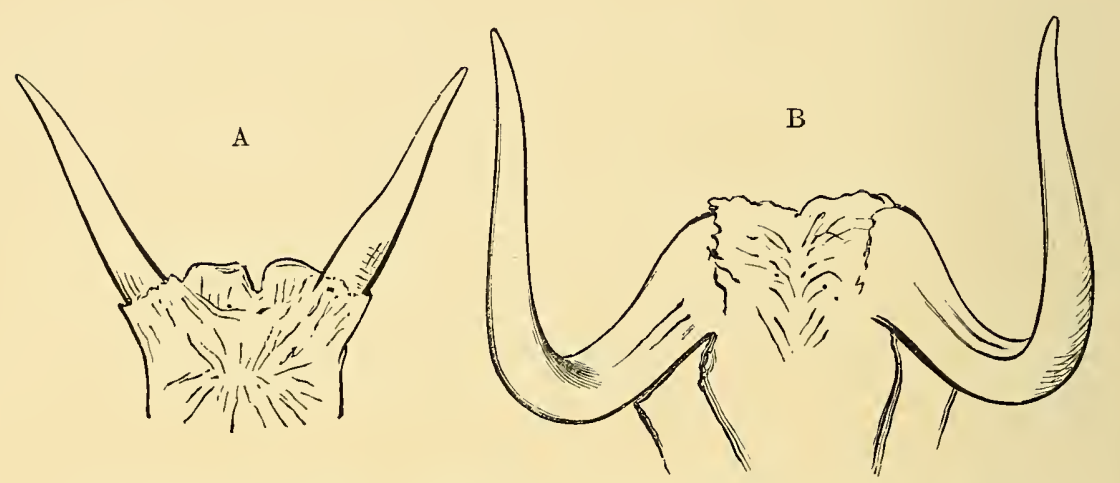

Fig. 45.-Horns of Black Wildebeest, A, eleven weeks old: B, 19 months old. (Proc. Zool. Soc.).

\section{Connochaetes taurinus. The Blue Wildebeest or Brindeled Gnu.}

Antilope taurina, Burchell, Travels ii, p. 278 (1824).

Catoblepas taurinus, H. Smith, Griff. Cuv. An. Kingd. iv, p. 369 v, p. 368 (1827) ; Smuts, Enum. Mamm. Cap. p. 94 (1832) ; A. Smith, S. Afr. Quart. Journ. ii, p. 233 (1834); id. Illustr. Zool. S. Afr. Mamm. pl. xxxviii (1849).

Catoblepas gorgon, H. Smith, Griff. Cuv. An. Kingd. iv, p. 371, v, p. 369 (1827) ; A. Smith, S. Afr. Quart. Journ. ii, p. 233 (1834) ; Selous, Proc. Zool. Soc. 1881, p. 764 [distribution] ; Barkley, ibid. 1894, p. 131 [Pungwe Valley].

Connochetes gorgon, Layard, Cat. Mamm. S. Afr. Mus. p. 76 (1861). 
Connochaetes taurinus, P. L. Sclater, List Anim. Zool. Gardens 8th ed., p. 150 (1883) ; Lorenz, Ann. kk. Hofmus. Wien ix, notiz. p. 60 (1894) [Western Transvaal] ; Rendall, Proc. Zool. Soc. 1895, p. 360 [Eastern Transval] ; P. L. Sclater and O. Thomas, Bk. of Antelopes i, p. 95, pl. xi, \& fig. 13 [woodeut of animal] (1895).

Catoblepas reichei, Noack, Zool. Anz. p. 153 (1893) [Upper Limpopo].

Literature.-Barrow (1806), p. 409, account of the discovery of the species by Messrs. Truter and Somerville, near Kuruman in Bechuanaland, under the name of the Kokoon; Daniell (1820), figured on pl. 37, also as Kokoon; Harris (1838), p. 59, first met this animal near where Vryburg now is ; id. (1840), figured on pl. iv; Methuen (1848), p. 74, met with near Ramah in the Orange Free State ; Cumming (1855), i, pp. 111, 167, shot this species south of the Orange River and also in Griqualand West; Livingstone (1857), p. 56, note on habits; Holub (1882), p. 107, in Western Transvaal; Bryden (1889), p. 293, distribution present and past; Nicolls and Eglington (1892), p. 47, pl. iii, fig. 8, description, distribution and habits ; Bryden (1893), pp. 356, 370, 375, 504, notes on habits and distribution, past and present; Millais (1895), p. 205, notes and sketches of this animal in south-east Mashonaland; Kirby (1896), pp. 281, 540, native names, habits and hunting in the eastern Transvaal ; Ward (1896), p. 89, horn measurements ; Bryden (1897), p. 200, chapter on hunting; Kirby (1899), p. 332, distribution in Beira-Zambesi Country; Bryden (1899a), p. 194, range and habits.

Vernacular Names.-Bastard or Blaauw Wildebeest of the Dutch Colonists ; Kaop of the Namaquas and Hottentots (Harris) ; Kolkon of the Bechuanas (Harris); Inkone-kone of Matabele (Selous) of Swazis and Zulus (Kirby) ; Ikokoni of Basutos (Kirby) ; Eevumba of the Makalaka and Numbo of the Masubias (Selous).

Description.-Larger than the other species, of a general bluish silvery grey colour with indistinct traces of brown transverse markings across the sides of the body; head not so wide as in the black species and with a somewhat arched profile; occiput, back of the ears, face and chin black or nearly so; hair on the face not reversed or tufted as in the other species but downwardly directed; a bare spot marks the opening of the antorbital gland; mane composed of long stiff upright black hairs extending from the occiput to the middle of the back behind the shoulder; tufts of black hairs on either side below the jaws and along the throat, but none between the fore legs; legs paler and browner than the general body colour; tail long, with terminal hairs extending to the false hoofs, the proximal third with short hairs like those of the body, the distal two thirds with long straight black hairs. 
Female resembling the male but with a more slender neck, and altogether less robust, also with two mammae. Horns with a comparatively small palm or base as compared with those of the other species, spreading outwards horizontally for about two thirds of their length and then curving right round so that the points are directed inwards and slightly backwards towards one another.

Skull large and heavy with a slightly arched profile.

Dimensions.-Of a mounted male; length of head and body along the curves $7 \mathrm{ft} .6$; tail without hairs $1 \mathrm{ft} .7$, with $3 \mathrm{ft.} .2$; height at shoulders $4 \mathrm{ft} .3$; ear $7 \cdot 25$; from ear opening to nose-tip $17 \cdot 5$.

A good pair of male horns measures 24 along the outer curve; of female horns 14 ; the records as given by Ward are $31 \frac{1}{4}$ from an individual obtained near Delagoa Bay, and 31 from one in the Lydenburg district of the Transvaal.

Skull of a male, length 18 , width $7 \cdot 5$.

Distribution.-The blue wildebeest was formèrly found all over South Africa from the Orange River to the Zambesi ; contrary to what is usually believed to be the case it even extended south of the former river, as is proved by the narrative of Gordon Cumming, who recounts the obtaining of a specimen under rather peculiar circumstances in what is now the Hopetown Division of the Colony. Throughout the high veld of the Orange Free State, Griqualand West and the Transvaal, it was formerly extremely abundant, as is evidenced by the writings of Harris and others, though now practically extinct. At the present time the blue wildebeest is to be found along the eastern borders of the Kalahari, from about the Molopo River northwards, in German South-west Africa, Ngamiland, Matabele and Mashonaland, in Portuguese territory, and the low hunting veld of the Eastern Transvaal southwards to about the northern portion of Zululand. North of the Zambesi in the Barotse and Mashukulumbe country a blue wildebeest is said to exist in considerable numbers, but whether this is of the present species or of the form recently described from Nyasaland has not yet been definitely decided.

The South African Museum possesses examples either of skins or horns of this species from Damaraland, Khama's territory, the Beira Country and the Lydenburg district of the Transvaal.

History.-The first travellers who met with this species of wildebeest, and who recognised its distinctness were Messrs. Truter and Somerville, who made a journey in 1801 as far as Litakun or Litakoo, in what is now the Kuruman district of Bechuanaland, to 
purchase cattle; an account of this journey is to be found in Barrow's Voyage to Cochin China, and a figure of the antelope under the name of kokoon was subsequently published by Daniell in 1820 .

To the observant and learned Burchell, however, we are indebted for the Latin name, and the earliest specimens brought home, one of which is still preserved in the British Museum; he met with the animal in June 1812 at the Khosi fountain between Klaarwater and Litakun in Southern Bechuanaland.

The best and most complete modern account of the natural history and hunting of the blue wildebeest is to be found in Kirby's book above quoted.

Habits. -The blue wildebeest is found in open down country devoid of bush, or sometimes in open glades of forest, but never in hilly or rocky places; Bryden asserts that this, like many other large antelopes, is now taking to bushy and forest country more and more, to escape the attacks of men; troops of from fifteen to sixty individuals are usually seen together though the old bulls are often found solitary; mingled with the herds are often seen other animals, especially Burchell's zebra. Harris describes them as inseparable from one another and terms them the Damon and Pythias of the animal creation; giraffe, ostrich and pallah are also often found associating with this species.

In pace wildebeests are swift and enduring, but when hunted they frequently turn impelled by curiosity to gaze at the pursuer and so fall victims; they gallop in a string, the females leading, the bulkier males bringing up the rear. They are seldom found far from water, where they drink usually at sundown and in early morning, and where also they are fond of wallowing, kneeling and rolling, and plastering themselves with mud. They usually lie down in a shady hollow during the day and feed in the late afternoon.

Altogether compared with the other wildebeest they are somewhat clumsy and stupid, and without their fire and dash, but still they exhibit all the quaintness and temper which make the other so remarkable; every one states that they are very tough animals to kill, often going a long distance after being badly wounded, and further that they will charge when wounded in a most dangerous manner.

Wild dogs often attack even this large and powerful beast, Cumming actually saw one run down by four.

The young are born in the Beira country between November and 
January, and are kept hidden by the mother in a patch of long grass or bush, and are jealously watched until old enough to run about by themselves.

The flesh is not very palatable, being coarse, hard and dry.

\section{Subfamily CEPHALOPHINAE.}

Antelopes of small or medium size; rhinarium well developed; antorbital gland large, opening (in the South African genus) in a row of pores along a naked line on the face; no knee brushes, four mammae, horns short and straight, usually present in both sexes.

\section{Genus CEPHALOPHUS.}

Cephalophus, H. Smith, Griff. An. Kingd. v, p. 344 (1827) ........................................... sylvicultrix. Sylxicapra, Ogilby, Proc. Zool. Soc. 1836, p. 138 ...C. grimmi. Grimmia, Laurillard, Dict. Univ. d'H. N. i, p. 623 (1839). C. rufilatus.

Size medium or small, build somewhat stout and clumsy; rhinarium large extending right round the nostrils; antorbital gland opening by a row of pores situated on a naked line which runs along the side of the face below and in front of the eye; crown of the head with tufts of long hairs usually concealing the bases of the horns; tail short or medium; lateral hoofs present but not very large; mammae four in number.

Skull with a large antorbital depression for the reception of the gland; the frontal bones projecting backwards between the parietals to support the posteriorly placed horn cores; upper molar teeth low crowned and square in the larger species, with an additional column on the inner side.

Horns generally present in both sexes, but not always, short, straight and spike-like, placed far back on the head with the bases generally ringed, angulated or roughened.

This is one of the largest of the genera of the antelopes, and is confined to Africa south of the Sahara; thirty-six species are recognised in the recently published "Book of Antelopes" and of these by far the greater number are inbabitants of the great West African 
Forest Region, and are consequently not very familiar either to naturalists or sportsmen.

Only three species reach South Africa and these may be discriminated in the following key.

$A$. Horns slanting upwards so as to form an angle with the facial profile; ears longer than the distance from the eye to the tip of the nose and pointed; height at shoulder about 22 inches

C. grimmi, p. 157.

$B$. Horns in a straight line with the facial profile, ears shorter than the distance from the eye to the tip of the nose, and rounded at their tips.

a. General colour rufous, standing about 18 in. at the shoulder

$b$. General colour smoky brown, standing about $13 \mathrm{in}$. at the shoulder

C. natalensis, p. 161.

C. monticola, p. 163.

\section{Cephalophus grimmi. The Duiker.}

Moschus grimmia, Linnaeus, Syst. Nat. 12th ed., i, p. 92 (1766).

Antilope nictitans, Thunberg, Mem. Acad. Petersb. iii, p. 312 (1811).

Cemas cana, Oken, Lehrb. Naturg. iii, pt. 2, p. 743 (1816).

Antilope mergens, Desmarest, N. Dict. d'Hist. Nat. (2), ii. p. 193 (1816); A. Smith, Descr. Cat. S. Afr. Mus. p. 24 (1826); Smuts, Enum. Mamm. Cap. p. 84 (1832); Lichtenstein, Darstellung Säugeth. pl. xi. (1828).

Antilope (Cephalophus) platous, burchelli et ptoox, H. Smith, Griff. An. Kingd. iv. pp. 260-5, v, p. 344 (1827); A. Smith, S. Afr. Quart. Journ. ii, pp. 214-5 (1834).

Cephalophus mergens, A. Smith, S. Afr. Quart. Journ.ii, p. 215 (1834); Selous, Proc. Zool. Soc. 1881, p. 763 [distribution].

Cephalophus campbelliae, Gray, List Mamm. B.M. p. 162 (1843); id. Ann. Mag. N.H. (1), xviii, p. 164 (1846); id. Knowsley Menagerie, p. 9 (1850) ; Layard, Cat. Mamm. S. Afr. Mus. p. 72 (1861).

Cephalophus grimmia, Gray, Knowsley Menag. p. 8, pls. i, ii, (1850) ; Layard, Cat. Mamm. S. Afr. Mus. p. 71 (1861); Buckley, Proc. Zool. Soc. 1876, p. 283 ; 1877, p. 453 [distribution].

Antilope altifrons et ocularis, Peters, Reise Mozambique Süugeth.pp. 184, 186, pls. xxxvii-ix, xli, fig. 1, xlii, fig. 1. [animal \& skull] (1852).

Cephalophus ptoox, Layard, Cat. Mamm. S. Afr. Mus. p. 71 (1861).

Grimmia nictitans et irrorata, Gray, Proc. Zool. Soc. 1871, p. 590, fig. 1 [skull].

Cephalophus grimmi, Gray, Proc. Zool. Soc. 1857, p. 277, pl. lvii, [animal]; Thomas, Proc. Zool. Soc. 1892, p. 428; Rendall, Proc. 
Zool. Soc. 1895, p. 362 [Eastern Transvaal] ; P. L. Sclater and O. Thomas, Bk. Antelopes, i, p. 203, pl. xxiii, \& fig. 22 [skull] (1895) ; Lorenz, Ann. k7. Hofmus, xi, p. 1 (1896) [Victoria falls].

Cephalophus grimmia flavescens, Lorenz, Ann. k.k. Hofmus, Wien, ix. notiz. p. 60 (1894).

Literature.-Grimm, Misc. Cur. Acad. Nat. Cur. (1686), dec. ii, ann. 4.p. 131, earliest description under the name of "Capra sylvestris africana"; Kolben, (1731), ii, p. 116, described as the "Diving goat" ; Burchell (1822), i, p. 187, description; Moodie (1835), i, p. 285, on the habits of the species; Harris (1838), p. 215, met with the Duiker in the Pretoria district of the Transvaal; id. (1840), figured on pl. xv, fig. 2; Delagorgue (1847), i, p. 303, discusses the distinction between the Natal and Cape Duikers; Livingstone (1857), p. 56, habits and native names; Grout (1863), p. 301, native name in Natal; Drummond (1875), p. 398, hunting and habits ; Nicolls and Eglington (1892), p. 27, pl. vii, fig. 26, description, distribution and habits ; Bryden (1893), p. 511, distribution in Bechuanaland; Lydekker (1893), p. 207, description; Kirby (1896), p. 541, native names and distribution in the eastern Transvaal; Ward (1896), p. 96, horn measurements ; Kirby (1899), p. 329, distribution in Portuguese East Africa; Kirby (1899a), p. 232, range and habits.

Vernacular Names.-Duiker or Duikerbok (i.e., Diving Goat) of the Colonists; Impunzi of Amaxosa (Cloete), Zulus (Grout), Swazi (Rendall), and Matabele (Selous); Iputi of Basuto (Kirby); Puti of Bechuanas (Livingstone); Pembgee of Makalakas, and Unsa of Masubias (Selous).

Description.-Size medium, form of the body somewhat delicate; general colour very variable, but usually speckled yellow brown, each hair being in its distal portion ringed black and yellow; below including the chin, belly, and insides of legs white; along the median line of the face a black streak usually extending to between the eyes sometimes to the bases of the horns; forehead and rest of the space between the eyes and horns together with the long hairs at the base of these bright rufous; ears long and pointed exceeding the distance from the front of the eye to the nose-tip, with white hairs inside; legs black in front and right round at the fetlock; tail very short, barely reaching halfway to the hocks, black above, white below.

Female with four mammae, and sometimes with, but more usually without horns.

The above description is founded on an example from Natal but as mentioned below there is a considerable range of individual variation in this species.

Skull long and narrow with the frontal region flat; antorbital 
fossae of medium depth with the border rounded not ridged; mesial notch of the palate extending some distance further back than the lateral notches.

Horns straight, slightly divergent, set at an angle to the line of the facial profile, roughened with three to six irregular rings at the base, smooth towards the tips, rather slender throughout, the basal diameter going to six or seven times in their length.

Of two female skulls in the South African Museum one only has rudimentary horns, these are knobs about half an inch in length.

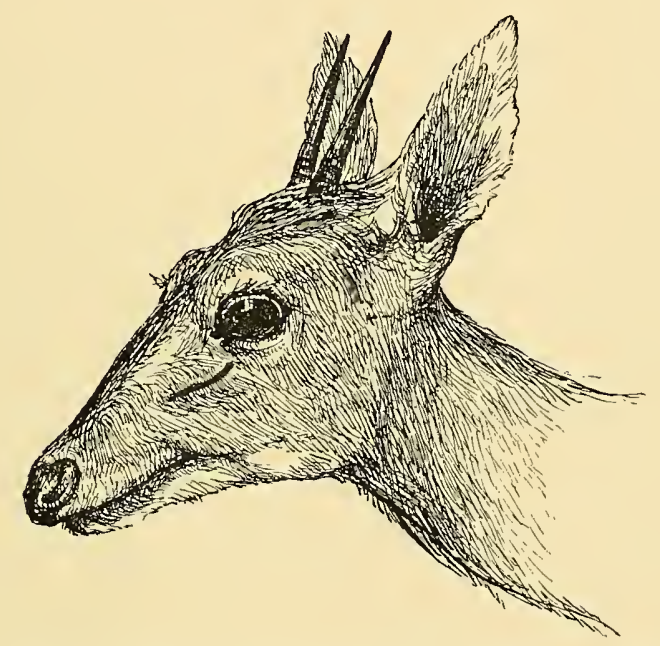

FIG. 46.-Head of the Duiker (Cephalophus grimmi).

Dimensions.-From a mounted male from Natal in the South African Museum; head and body 38.50 ; tail without terminal hairs $3 \cdot 0$, with $5 \cdot 0$; height at shoulder 22.5 ; ear 4.5 ; ear opening to nose-tip 8.0.

The horns of the males average about 3.75 in length, but have been known, according to Kirby, to attain a length of 6 ; according to Ward the record is $5 \cdot 5$.

The skull of a male in the South African Museum measures $7 \cdot 0$ in length, and 3.0 in breadth.

Synonymy and Yariation. - All who have had opportunities of observing this little antelope have remarked on the great individual variation manifested by it, even in comparatively restricted localities; 
but until a good many more specimens have been collected and compared from different districts it will not be possible to distinguish any geographical races.

According to both Kirby and Selous, the general colour of individuals varies from a silvery grey to a greenish and also a reddish brown; the under parts also vary from a pure white to a colour only slightly paler than the upper surface.

As a result of this systematists have assigned a very large number of specific names to slight variations in colour. C. burchelli and C. ptoox of H. Smith, to the descriptions of which no particular localities are attached, appear to have been founded on a very old and somewhat faded and a young specimen respectively, while C. campbelliae of Gray, from Natal, may possibly turn out to be subspecifically separable from the type of the western part of the Colony.

Distribution.-The duiker appears to be found over a wide area in Africa, extending from the Colony northwards to Angola ${ }^{1}$ on the west, and to Somaliland on the east; south of the Zambesi it seems to be common everywhere in suitable localities, and I have information of its occurrence in nearly every division of the Colony, in Natal, the Orange Free State, the Transvaal and Rhodesia.

History.-This little antelope being common around Cape Town soon attracted the attention of the Colonists, so that it was noticed earlier than almost any other purely South African animal, being described in 1686 by Grimm as mentioned above. Kolben alludes to it under the name of the "diving goat," and Linnaeus, on establishing his binomial system, dedicated this species to its first describer Grimm; it is noticed by nearly all the naturalists and sportsmen who have visited or written on South Africa.

Habits.-The duiker is found generally in open country covered with scattered bush, and is most common near the sea coast; it is not as a rule to be found in rocky hills or absolutely bare lands; it is usually seen solitary or sometimes in pairs, and rests during the day in thick cover, coming out to feed in early morning or on moonlight nights; in pace it is very fast, and when molested it makes off, taking, after five or six strides, great jumps into the air as if to see over the tops of bushes, and then "diving" back again underneath the cover; when wounded it screams like a hare.

According to Kirby the food of the duiker consists of the leaves

1 I have seen a specimen from St. Paul de Loanda. 
of shrubs, wild berries and fruits, but Dr. Lindley, to whom I am indebted for some notes on the smaller antelopes, informs me that grass constitutes the greater part of its nourishment; this may easily be due to the fact that its habits in the eastern Transvaal, and in the south-western districts of the Colony, are very different; all authors, however, agree that the duiker is almost entirely independent of water, and that it is found in numbers in parts of the Kalahari where there is no permanent water present throughout the year.

Dr. Lindley informs me that the young are born in spring, i.e., in September or October, and that only one, or exceptionally two are produced at a birth.

The duiker is frequently seen in the European Zoological Gardens, and also in South Africa in captivity, but does not as a rule live long or thrive though it becomes fairly tame.

The meat is said to be rather inferior and dry for eating.

\section{Cephalophus natalensis. The Red DutKer.}

Cephalophus natalensis, A. Smith, S. Afr. Quart. Journ. ii, p. 217 (1834); id. Illustr. Zool. S. Afr. Mamm. pl. xxxii (1841); Thomas, Proc. Zool. Soc. 1892, p. 419; P. L. Sclater and Thomas, Bk. Antelopes, i, p. 139, pl. xvi (1895).

LITERATURE.-Delagorgue (1847), i, p. 262, account of habits and occurrence; Grout (1863), p. 302, described under its native name, with an account of habits; Drummond (1875), p. 391, note on its occurrence in Natal ; Nicolls and Eglington (1892), p. 23, pl. i, fig. 2, description and distribution; Lydekker (1893), p. 209, description; Kirby (1896), p. 541, native names and habits in the Eastern Transvaal ; Ward (1896), p. 98, horn measurements; Kirby (1899), p. 320, distribution in Mozambique; Kirby and Rendall (1899a), p. 218, range and habits.

Vernacular Names.-The Redbuck or Natal Redbuck, the Roodebol or Rooi-bosch-bokje of the Colonists, English and Dutch; Umkumbe or 'Mkumbi of Zulus, 'Msumbi of Swazis and Isikupu of Basutos (Kirby).

Description.-General colour a rich rufous, somewhat paler below, smoky about the neck and face, but a rich rufous again between the horns and eyes; the tuft of long hairs concealing the bases of the horns well developed and mingled rufous and black; edge of the upper lip, lower jaw and upper throat whitish; ears shorter than the distance from the front of the eye to the tip of the nose, broad and rounded at their tips, posteriorly with a thin 
sprinkling of short smoky hairs, inside with a few white hairs ; tail, slender, reddish at the base with mixed black and white, rather longer hairs at the tip.

Skull smaller than that of the common duiker, and with a somewhat rounded profile owing to the convexity of the frontals, edge of the median palatal notch nearly on a level with those of the lateral notches.

Horns short, nearly concealed by the long hairs, set parallel to the facial profile, pyramidal with stout bases, their diameter going about three times in their length; basal portion with about three rings, tips longitudinally striated; the females almost invariably provided with similar but shorter and smaller horns.

Dimensions.-Of a male now in the South African Museum, measured in the flesh by Mr. Francis; head and body 31.50 ; tail without hairs 4 , with $5 \cdot 50$; height at shoulder 17 ; ears 3.0 ; from ear to nose-tip 6.5 .

Skull basal length $5 \cdot 85$; greatest width $2 \cdot 75$.

Horns from $2 \cdot 50$ to $3 \cdot 0$, the record, according to Ward, being 3.25 ; the horns of the female are about half the length of those of the male. Rams weigh 26 to $28 \mathrm{lbs}$., ewes 28 to $31 \mathrm{lbs}$.

Distribution.-The type of this species was obtained in the immediate neighbourhood of Durban, and it has since been ascertained to range thence northwards along the coast and low country as far as Zanzibar ; it is reported also to range as far as Pondoland and Tembuland in the extreme east of the Colony, but I have seen no specimen thence; it is not uncommon in the eastern Transvaal and Swaziland, and the South African Museum possesses examples both from Natal and from Komatipoort in the Lydenburg district of the Transvaal.

History. - This little antelope was first discriminated by Sir Andrew Smith in 1834, at the time of the commencement of the settlement at Natal; as can be seen by the list of literature and synonymy not much attention has been paid to it since; perhaps the best account will be found in Mr. Kirby's works there quoted.

Habits.-The red duiker is essentially a forest dweller; it is found chiefly along the coast, and in the low country, inhabiting the thickest bush and kloofs where there is water, and seldom emerges except in the evening or in wet weather; it is, as a rule, solitary in its habits and endowed with very acute senses; when disturbed it makes great rushes through the bush and reveals, according to Delagorgue, its presence when in flight by a nasal 
sniffing; its call is a sharp whistle seldom heard; when caught it emits a deep and somewhat rough sound quite different from the hare-like scream of the common duiker; according to Kirby its food consists entirely of leaves, wild fruits and berries; the female produces one young one every year. There is considerable divergence of opinion as regards its palatability, Drummond and Rendall not appreciating it at all, while Delagorgue and Kirby both state that the flesh is excellent.

\section{Cephalophus monticola. The Buue DuiKer.}

Capra monticola, Thunberg, Resa ii, p. 66 (1789), id. English Trans. ii, p. 58 (1793).

Antilope monticola, Thunberg, Mem. Acad. Petersb. iii, p. 314 (1811).

Antilope pygmaea, apud A. Smith, Descr. Cat. S. Afr. Mus. p. 23 (1826); Smuts, Enum. Mamm. Cap. p. 86 (1832) [nec Linn.].

Antilope (Cephalophus) caerula et perpusilla, H. Smith, Griff. An. Kingd. iv, p. 268-9, v, p. 348 (1827) ; A. Smith, S. Afr. Quart. Journ. ii, p. $216-7$ (1834).

Antilope minuta, Forster, Descr. Anim. p. 383 (1844).

Cephalophus monticola, Gray, Ann. Mag. N. H. (1), xviii, p. 167 (1846); Thomas, Proc. Zool. Soc. 1892, p. 427; Rendall, Proc. Zool. Soc. 1895, p. 361 [Transvaal] ; P. L. Sclater and O. Thomas, Book of Antelopes, i, p. 191, pl. xxi, fig. i (1895).

Sylvicapra monticola, Grill, K. Vet. Akad. Handl. Stockholm, ii, 2, p. 19 (1858).

Cephalophus pygmaeus, Layard, Cat. Mamm. S. Afr. Mus. p. 72 (1861). Cephalophus bicolor, Gray, Proc. Zool. Soc. 1862, p. 263, pl. xxiv [piebald var].

Literature.-Sparrman (1785), i, p. 297, once saw this species in the Zitzikamma forest in Knysna; Moodie (1835), ii, p. 139, notes it as abundant in the Alexandria division; Harris (1840), figured on pl. xxvi, fig. 3 ; Grout (1863), p. 301, occurrence in Natal; Drummond (1875), p. 392, hunting in Natal; Nicolls and Eglington (1892), p. 29, pl. iv, fig. 11, description and distribution; Lydekker (1893), p. 207, description; Ward (1896), p. 97, horn measurements : Kirby (1899 a), p. 229, range and habits.

Vernacular Names.-Blaauwbok or Kleenebok of the Dutch Colonists; Peté of the Natal Colonists ; Noumetje (Smith) or Gnometie (Sparrman) of the Hottentots; Iputi of Amaxosa (Cloete); Ipiti of the Zulus (Grout).

Description.-The smallest of South African antelopes, being about the size of a hare and standing higher at the hind quarters than at the shoulders; general colour a smoky grey brown, below 
and on the insides of the legs becoming white; a longitudinal black patch on the nose, and a dark smoky brown patch on the forehead bordered on either side by a somewhat more rufous brown line; ears short, broad and rounded, their length falling short by a considerable amount the distance from the anterior border of the eye to the tip of the nose, posteriorly dark brown, anteriorly with sparse white hairs and a dark brown edging ; limbs, which are very slender, distinctly rufous brown contrasting with the general colour of the body; hoofs narrow and pointed; tail short with spreading fluffy hairs, black in the middle line above, white on the sides and below.

Skull like that of the red duiker with a somewhat swelling frontal region, and horn cores backwardly directed in a line with the profile.

Horns present in both sexes as a rule, like those of the red duiker but smaller, roughly ringed at their bases and smooth terminally.

Dimensions.--Of a male now in the South African Museum measured in the flesh by Mr. Kirby; head and body along the curves 24 ; tail without terminal hairs 2.25 , with $3 \cdot 0$; height at the shoulder 14 ; ear 1.75 ; from ear opening to nose-lip $5 \cdot 0$.

Skull length 4.50 ; breadth 2.25 .

Horns of a male average about $1 \cdot 75$, the record according to Ward is 2.06 .

Distribution.-The blaauw-bok is found only in the more wooded districts of the Colony, that is along the Coast from George eastwards to Natal and Zululand; whether its range extends beyond the limits of South Africa is at present uncertain, but a species closely allied, if not identical, appears to occur in Nyasaland and Mozambique, and according to Professor B. de Bocage in Benguela and Loando on the West Coast.

The South African Museum possesses specimens from the Knysna and Humansdorp divisions of the Colony.

History.-The blue duiker was known to the travellers of the end of the last century. Sparrman noticed it but did not venture to name it, so that to Thunberg another Swede belongs the credit-if credit there be-of having first given what one cannot but regard as a most unsuitable name to this animal ; furthermore to his description, which obviously does apply to the present species, he adds the Dutch name for it of "ourebi," which, of course, is connected with quite a different animal. The name "pygmaea" also frequently 
applied to this species, more properly, as has been shown by Sir Victor Brooke, belongs to the little, so-called royal antelope of West Africa, so that, though perhaps reluctantly, we must adopt Thunberg's name.

Habits.-Little is recorded about the habits of this buck; it is found only in the densest bush and forest moving about during the day and resting at night; it feeds on the leaves of shrubs and bushes and on berries. It drinks, according to Kirby, once a day in the evening, but in very hot weather will often drink again at midday; the alarm cry is a sharp whistling shriek; the fawns are usually born during the rains, i.e., in September or October. The flesh is palatable, according to Kirby, though stated by others to be somewhat musky.

\section{Subfamily NEOTRAGINAE.}

Small antelopes with naked or hairy muzzles; antorbital gland with a round opening; false hoofs present or absent; horns in the male only, short, straight and ringed basally, at least.

\section{Key of the South African Genera.}

A. Nose truncate not elongated, a considerable rhinarium, no tuft of hairs on the crown.

a. Hoofs cylindrical and blunt; hair very coarse and pithy, like bristles

Oreotragus, p. 165.

b. Hoofs nomal and pointed.

$a^{1}$. A glandular naked spot below the ears, knee

brushes and accessory hoofs...................
$b^{1}$. No glandular naked spot below the ears or

Ourebia, p. 169. knee brushes.

$a^{2}$. Horns vertical and upright....

Raphicerus, p. 172.

$b^{2}$. Horns directed backwards parallel to the back

Nesotragus, p. 178.

$B$. Nose elongated, rhinarium practically absent; tuft of hairs on the crown of the head

Madoqua, p. 181.

\section{Genus OREOTRAGUS.}

Oreotragus, A. Smith, S. Afr. Quart. Journ. ii, p. 212

Type.

O. saltator.

Small antelopes clothed with thick pithy bristles resembling the coat of a musk-deer or prongbuck and entirely different from that 
of other South African antelopes; muzzle with a large naked rhinarium between the nostrils; antorbital glands very large opening by a circular aperture on a bare patch of skin in front of the eye; hoofs cylindrical and blunt, quite different from those of other antelopes, as the animal walks on the tips only of the hoofs which are thus vertical, and the leg is normally without a bend at the pastern or hock joint, and forms a straight line down to the hoofs; accessory hoofs present; two mammae.

Skull short and broad with large antorbital fossae, frontal bones not backwardly projecting as in Cephalophus, but bearing the horn cores above the orbits.

Horns present in the males only, short, straight and slightly curved forwards.

Only one recent species of this genus is recognised from South and East Africa, extending from Cape Colony to Abyssinia. A fossil form named $O$. hastata by Gervais is known from the pliocene deposits of the South of France.

\section{Oreotragus saltator. The Klipspringer.}

Antilope oreotragus, Zimmermann, Geogr. Gesch. iii, p. 269 (1783); Thunberg, Mem. Acad. Petersb. iii, p. 311 (1811); A. Smith, Descr. Cat. S. Afr. Mus. p. 24 (1826).

Antilope saltatrix, Boddaert, Elench. p. 141 (1785).

Tragulus oreotragus, Smuts, Enum. Mamm. Cap. p. 79 (1832).

Oreotragus typicus, A. Smith, S. Afr. Quart. Journ. ii, p. 212 (1834).

Oreotragus saltator, Layard, Cat. Mamm. S. Afr. Mus. p. 70 (1861); Rendall, Proc. Zool. Soc. 1895, p. 361 [Transvaal] ; P. L. Sclater and $O$. Thomas, Bk. Antelopes, ii, p. 5, pl. xxv (1896).

Nanotragus oreotragus, Brooke, Proc. Zool. Soc. 1872, p. 642 ; Buckley, ibid. 1876, p. 283 [distribution] ; Selous, ibid. 1881, p. 762 [distribution].

Literature.-Buffon (1782), Suppl. vi, p. 183, pl. xxii, earliest notice of species; le Vaillant (1796), ii, p. 28, account of habits; Steedman (1835), ii, p. 9, notice with plate, of the habits near Beaufort West; Harris (1838), p. 214, met with in the Pretoria District; id. (1840), figured on pl, xxiv, fig. 2; Drummond (1875), p. 396, habits and occurrence in Natal; Bryden (1889), p. 67, account of shooting in the Colony with photograph of head; Nicolls and Eglington (1892), p. 26, pl. v, fig. 18, description, distribution and habits ; Bryden (1893), pp. 440, 511, common in Bechuanaland; Selous (1893), p. 162, habits in Mashonaland; Lydekker (1893), p. 219, description; Millais (1895), p. 92, sketches and notes in Zoutspansberg, Transvaal; Kirby 
(1896), p. 543, native names and habits in the Eastern Transvaal; Ward (1896), p. 117, horn measurements; Kirby (1899), p. 329, distribution in Mozambique ; Kirby (1899a), p. 235, range and habits.

Vernacular Names.-Klip-springer or Klip-bok of the Colonists ; Kainsi of Hottentots (le Vaillant) ; Igogo of Amaxosa (Stanford) ; 'Ligoka of Swazi, Ikumi of Basuto (Kirby) Ee-go-go of Matabele; Ingululu of Makalakas, Kululu of Masaras (Selous).

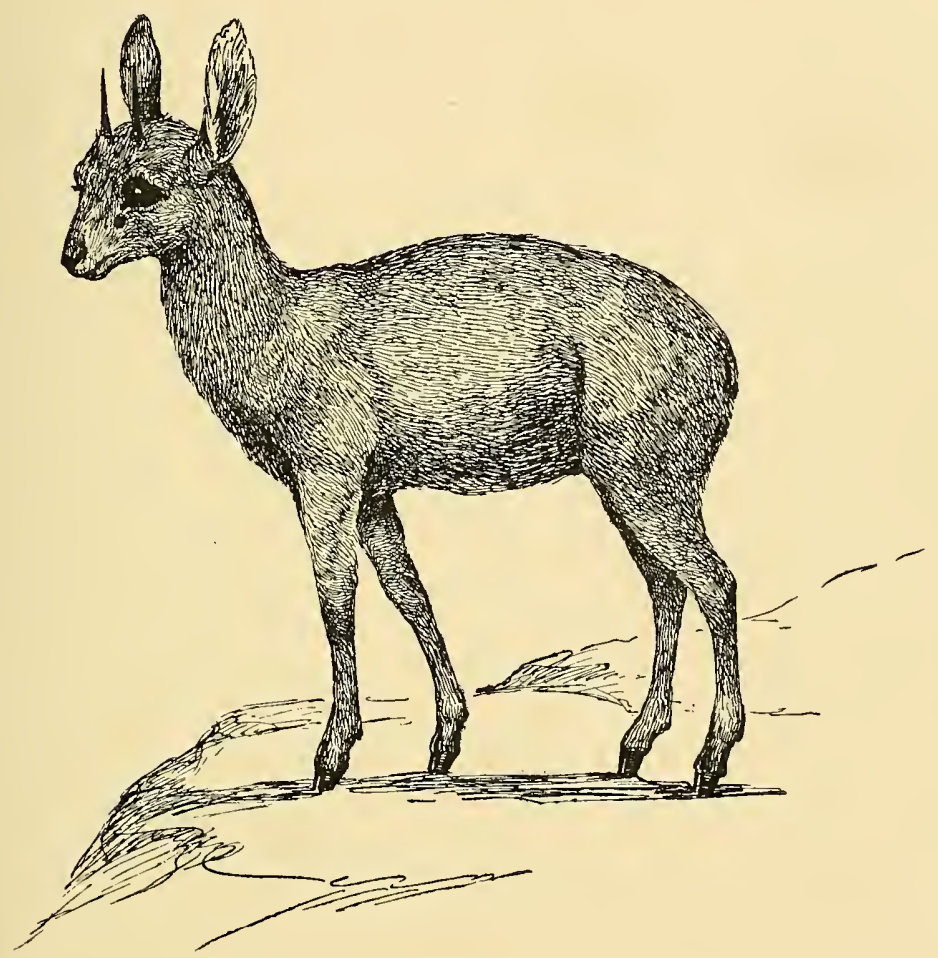

FIG. 47.-The Klipspringer (Oreotragus saltator).

Description.-General colour speckled yellow and brown; hair very coarse, flattened in section, wavy, close lying and thick, forming a species of cushion all over the body of the animal; colour white to pale grey at the base, yellow at the tip, brown in the intermediate portion; below including the chin and the inner side of the limbs, paler, often quite white; head triangular and pointed; rhinarium large but not completely surrounding the nostrils; 
antorbital gland opening on a bare spot in front of the eye; ears of moderate length slightly longer than the distance from the front of the eye to the nostrils, clothed along the margins with black and inside with white hairs; limbs like the body; hoofs as described above; tail very short, hardly projecting beyond the contour of the body, about an inch in length.

Horns in the male only, short and straight and set somewhat distant from one another, nearly upright, the basal third irregularly ringed, the distal two-thirds smooth.

Dimensions.-From a mounted male ; head and body 38.0 , tail about 1.0 ; height at shoulders 23.0 ; ears 3.40 , ear to nose-tip 6.0 ; skull length $5 \cdot 25$; breadth $3 \cdot 13$.

Horns average about 3 inches in length; Kirby states his record to be $5 \frac{1}{8}$; Ward gives $5 \frac{3}{4}$ in the ease of a head from Mashonaland.

Distribution.--The klipspringer appears to be found in suitable localities throughout the whole of South Africa from the Cape Peninsula to the Zambesi ; beyond our boundary it ranges through East Africa as far north as Somaliland and Abyssinia.

The klipspringer seems to be recorded from almost every district, where there are rocky hills; the South African Museum possesses examples from Pretoria, Worcester and Beaufort West, and there is still a considerable number of these antelopes on the hills running from Table Mountain to Cape Point in the immediate neighbourhood of Cape Town.

History.-The earliest notice of the klipspringer with which I am acquainted, is by Buffon (1782), whose account was derived from the Fosters, the naturalists who accompanied Captain Cook on his second voyage round the world and stayed for some time at the Cape; although the description is accurate and quite obviously refers to our species the plate is very poor, and is much more like an oribi than a klipspringer.

Not much attention has been since paid to this species, but Harris and Bryden give on the whole the best account of their habits and shooting.

Habits.-The klipspringer, as its name implies, is found always among rocks and boulders, and in the Colony is said only to occur at considerable elevations ; further north, however, it frequents the low rocky "kopjes" which rise out of the plains, and form so characteristic a feature of the landscape, while in Mashonaland Mr. Selous reports that it is frequently found at quite low elevations in rocky river beds. 
They associate in small troops of three to eight, and are extraordinarily active and agile "bounding from ledge to ledge on which no human eye can mark a footing, balancing at one moment upon the giddy verge of a precipice where hardly sufficient space exists for the hoof to rest, at the next casting themselves recklessly into the bottomless chasm and pitching as if by miracle upon some projecting peak where all four feet appear to be gathered into the space of one"; when caught on level ground they can be easily overtaken; their food consists chiefly of the alpine plants and grasses clothing the hill-tops, but they descend regularly generally during the night to drink ; nothing is recorded about their breeding habits.

In captivity they become very tame though, as a rule, they do not live long. They can be easily shot, especially if hunted by dogs, when they generally take refuge on some more or less inaccessible pinacle and form an easy mark for the bullet.

Their hair is stated to be greatly valued for stuffing saddles, in consequence no doubt of its elasticity, and their flesh is by all stated to be excellent eating.

Mr. Bryden relates a curious story to the effect that the Bechuanas are in the habit of catching the young klipspringers alive and carrying them about, pinching them from time to time to make them squeal; this they do as a charm to bring down rain.

\section{Genus OUREBIA.}

Ourebia, Laurillard, Dict. Univ. d'Hist. Nat., i, p. 622 (1839)

Type.

Scopophorus, Gray, Ann. Mag. N.H. (1) xviii, p. 232

(1846) O. scoparia.

Small antelopes with normal hair and hoofs, the latter being sharp-pointed and triangular, so that the animal does not rest on their points; tufts of long hair on the knees; accessory hoofs present; a glandular bare spot below the ear ; tail short and tufted with a few long black hairs.

Skull with very large antorbital fossae whose edges are sharply ridged above and below; nasal bones long.

Horns in the male only, straight, slanting backwards and ridged basally.

This genus is confined to Africa, south of the Sahara; five species, all rather closely allied, are recognised and described in 
the recently published Book of Antelopes, and of these only the one below treated of enters our region.

\section{Ourebia scoparia. The OrIBI.}

Antilope ourebi, Zimmermann, Geogr. Gesch. iii, p. 268 (1783); A. Smith, Descr. Cat. S. Afr. Mus. p. 21 (1826).

Antilope scoparia, Schreber, Säugeth. pl. cclxi, (1785); Lichtenstein Darstell. Säugeth. pl. xiii (1828).

Antilope (Redunca) scoparia, Smuts, Enum. Mamm. Cap. p. 78 (1832); A. Smith, S. Afr. Quart. Journ. ii, p. 211 (1834).

Ourebia scoparia, Laurillard, Dict. Univ. d'Hist. Nat. i, p. 623 (1839) ; P. L. Sclater and O. Thomas, Bk. Antelopes, ii, p. 15, fig. 23 [woodcut of animal] (1896).

Scopophorus ourebi, Layard, Cat. Mamm. S. Afr. Mus., p. 70 (1861).

Nanotragus scoparius, Brooke, Proc. Zool. Soc. 1872, p. 642; Selous, ibid, 1881, p. 761 [distribution].

Neotragus scoparius, Barkley, Proc. Zool. Soc. 1894, p. 132 [Pungwe Valley] ; Rendall, ibid, 1895, p. 361 [Eastern Transvaal].

Literature.-Allamand (1776), v, p. 33, pl. v. first description of the Ourebi; Barrow (1801), p. 138, met with the "Orabie" near Algoa Bay; Harris (1838), p. 215, occurrence in the Pretoria district; Grout (1863), p. 302, native names, habits and description in Natal; Drummond (1875), p. 395, on hunting and habits in Natal ; Nicolls and Eglington (1892), p. 25, pl. v, fig. 15, description, distribution and habits; Lydekker (1893), p. 218, description; Kirby (1896), p. 542, native names and habits in the Eastern Transvaal; Ward (1896), p. 111, horn measurements ; Kirby (1899), p. 329, distribution in Mozambique; Kirby (1899a), p. 239, range and habits.

Vernacular Names.-Ourebi, Ourebikje, or sometimes perhaps Bleekbok of the Colonists : Iula of Amaxosa (Stanford); of Zulus (Drummond); and of Swazis (Kirby) ; Pulukudukamani of Basutos (Kirby).

Description.-General colour a yellow rufous, darkest on the frontal region; below and inside the upper part of the limbs white, sharply defined from the colour of the back and sides; rhinarium large, extending right round the nostrils; upper and lower lip and a broad eyebrow white, antorbital gland opening in a small depression in front of the eye; ears rather narrow, in length hardly reaching the distance from the front of the eye to the nose-tip; covered posteriorly with short rufous hairs, anteriorly and within with long white hairs, their margins narrowly edged with brown, a conspicuous glandular bare spot below the base of the ear on either side; limbs slender, with long hairs clothing the knees and forming 
brushes, false hoofs small, true hoofs narrow and pointed; tail very short coloured like the body witb a few longer black hairs.

Skull with a long slender muzzle; supra-orbital vacuities present; antorbital fossae large and open, sharply ridged above and below.

Horns short, slender, evenly tapering, set fairly near one another and curving slightly forwards, their basal thirds covered with closely set rings.

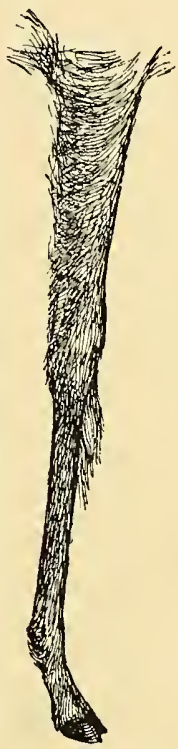

FIG. 48.-Fore leg of the Oribi (Ourebia scoparia) to show the knee-tufts.

Female with knee brushes but no horns.

Dimensions.-From a mounted male; head and body 40.0 ; tail with hairs $4 \cdot 0$, without $2 \cdot 0$; height at shoulder $25 \cdot 0$; from ear opening to nose tip $7 \cdot 0$; ear from notch $3 \cdot 8$; skull, basal length $5 \cdot 8$; greatest breadth 2.9 .

Horns average about 4 to 5 inches; Selous gives 5 as his longest pair, and Ward gives 6 as the record from a pair obtained in the Transvaal.

Distribution.-The oribi is found only in the eastern part of our region; in the Colony it is found in Uitenhage and the greater number of the districts further east to Natal where it is not 
uncommon in the midland districts, Züluland and the Pungwe Valley; from the seabord it extends inland to Basutoland, the eastern Transvaal and the low country of Mashonaland about Victoria; it is also, according to Selous, found in the neigbourhood of the Victoria Falls on the Zambesi. Oribis are said to be common north of that river, in Barotseland, Nyasaland and Mozambique; but these animals are usually referred to another species (Ourebia hastata) which, however, appears to be distinguishable only by its tail, which is somewhat slenderer and shows some white.

History.-The first writer who appears to have noticed this antelope was Professor Allamand, who described and figured it in Holland in 1776 ; on his description the Latin names of Zimmermann and Schreber are founded. Barrow, the English traveller, met with it on his eastern journey near Algoa Bay where it is still to be found; among subsequent writers, Drummond and Kirby have given some accounts of its habits.

Habits.-The oribi is found chiefly in open grass country and treeless plains, though in the Pungwe valley Barkley asserts that it frequents bush and not open country; they go in pairs or sometimes in small troops of four or five which, however, usually break up into couples on being disturbed.

They are very swift and active and it takes a very good dog to run them down. They try to escape by leaps and doubles like a hare; notwithstanding this they are easy to approach, lying very close and trusting to their resemblance to their surroundings to escape detection; they are seldom far from water; their flesh is exceedingly palatable and their skins were much sought after in former days by the Kaffir chiefs who paid as much as a cow for them.

\section{Genus RAPHICERUS.}

Raphicerus, H. Smith, Griff. An. Kingd. v, p. 342

Type.

(1827)

R. campestris.

Calotragus, Sundevall, K. Vet. Akad. Handl. Stock-

holm, 1844, p. 192 (1846) .......................... campestris.

Small antelopes with no naked glandular spot below the ears, no knee tufts, and with the accessory hoofs present or absent; tail very short; inguinal pores present; two mammae. Skull stout 
and strong, with small but deep antorbital fossae with unridged edges above and below.

Horns in the males only, short and vertical.

This genus is confined to South and East Africa. In addition to the well-known steenbok and grysbok from South Africa noticed below two other species have been described, these are :-

Raphicerus neumanni.-Closely allied to the steenbok and distinguished from it only by the absence of the black marking on the head, obtained in German and British East Africa.

Raphicerus sharpei.-A curious intermediate form with the white grizzling of the grysbok and the feet of a steenbok, only known from a single specimen obtained by $\mathrm{Mr}$. A. Sharpe in Angoniland in British Central Africa.

\section{Key of the South African Species.}

A. General colour pure brown, no accessory hoofs to limbs R. compestris, p. 173.

$B$. General colour reddish brown grizzled by numerous interspersed white hairs, accessory hoofs present

R. melanotis, p. 176.

\section{Raphicerus campestris. The Steenвoк.}

Antilope campestris, Thunberg, Mem. Acad. Petersb. iii, p. 313 (1811). Antilope tragulus, palida et rupestris, Lichtenstein, Mag. nat. Fr. Berlin, vi, p. 176 (1814); Smuts, Enum. Mamm. Cap. p. 81 (1832). Antilope pediotragus, Afzel, N. Act. Ups. vii, pp. 260, 264 (1815).

Antilope rupestris, Burchell, Travels, i, p. 202 (1822); A. Smith, Descr. Cat. S. Afr. Mus. p. 23 (1826).

Cerophorus stenbock et acuticornis, Blainville, Bull. Soc. Philom. p. 75 (1816).

Antilope (Raphicerus) subulata, H. Smith, Griff. An. Kingd. iv. pp. 249,253 (1827).

Tragulus rupestris, rufescens et pediotragus, A. Smith, S. Afr. Quart. Journ. ii, p. 212 (1834).

Calotragus tragulus, Grill, K. Vetens. Akad. Handl. Stockholm, ii, 2, p. 20 (1858).

Calotragus campestris et rufescens, Layard, Cat. Mamm. S. Afr. Murs. p. 68 (1861).

Nanotragus tragulus, Brooke, Proc. Zool. Soc. 1872, pp. 642, 874 ; Buckley, ibid. 1876, p. 283 [distribution]: Selous, ibid. 1881, p. 762 [distribution]. 
Nanotragus campestris, Lorenz, Ann. kk. Hofmus. Wien ix, notiz. p. 60 (1894).

Neotragus campestris, Rendall, Proc. Zool. Soc. 1895, p. 361 [Eastern Transvaal].

Raphicerus campestris, P. L. Sclater and O. Thomas, Bk. Antelopes, ii, p. 41, pl. xxvii, fig. 1 (1896).

Literature.-Masson (1776), p. 269, earliest mention of the Steenbok; Buffon (1782), Suppl. vi, p. 185, notice of this species derived from accounts of the Fosters; Thunberg (1793), ii, p. 7, note on this species near Cape Town; Harris (1838), p. 215, met with in the Pretoria district; id. (1840), figured on pl. xxv, fig. 2 ; Livingstone (1857), p. 56, note on habits and native name in Bechuanaland; Grout (1863), p. 302, on its native name and habits in Natal; Drummond (1875), p. 395, shooting; Nicolls and Eglington (1892), p. 24, pl. ii, fig. 6, description, distribution and habits ; Bryden (1893), p. 510, distribution in Bechuanaland; Lydekker (1893), p. 217, description ; Kirby (1896), p. 542, native names and habits in the Eastern Transvaal; Ward (1896), p. 114, horn measurements ; Kirby (1899), p. 329, distribution in Mozambique; Kirby (1899a), p. 251, range and habits.

Vernacular Nanes.-Steinbok, or more correctly Steenbok, Vlaktebok and Bleek-bok of the Colonists, Dutch and English ; Itshabanqa of Amaxosa (Stanford) ; Iquina of Zulus (Grout) ; Ingaina of Swazis, Impulupudi of Basutos (Kirby); Phuduhuru of Bechuanas (Nicolls and Eglington); Umgwena of Matabele (Nicolls and Eglington) ; Ee-pen-nee of Makalakas ; Kapu of Masubias; Gaiee of Masaras (Selous); Shipeni of Shangaans (Rendall).

Description.-Form slim and slender; general colour a rufous brown, often with a light silvery sheen; below, including the buttocks, white or nearly so ; head pointed and slender; rhinarium large between the nostrils only; behind it a black mark extends backwards along the nose half-way to the eye; forehead rather more richly coloured than the rest of the body; antorbital glands opening by a round aperture on a bare black space in front of the eye; a white supra-orbital stripe above the eye; ears large, broad and patulous varying somewhat in size but always far exceeding in length the distance of the front of the eye from the nose-tip, posteriorly very thinly covered with dark, anteriorly with a few long white hairs; a black Y-shaped mark on the head between the horns usually present but not constant; a patch of black bare skin at the groin where the inguinal glands open; limbs slender, no knee brushes or false hoofs; true hoofs long, narrow and pointed; tail very short, the same colour as the back.

Female similar, but hornless and with two mammae. 
Skull with a rather deep somewhat triangular recess for the reception of the antorbital gland; a vacuity in the frontals above; the upper surface roughened and ridged.

Horns smooth, slender, straight and black, a little roughened sometimes at the base but practically unridged, generally slightly curved forwards.

Dimensions. - Of a male; head and body 34.5 ; tail without hair 1.50 , with 2.25 ; height at shoulder 20.0 ; ears 3.8 ; ear opening to nose-tip $6 \cdot 50$. Skull, basal length $5 \cdot 0$; greatest breadth $2 \cdot 60$.

Horns average 4 to 4.50 in length ; Selous gives 5.0 as his record, Ward 5.8.

Distribution.-The steenbok is on the whole the commonest and most widely distributed of all the South African antelopes; it is found everywhere, from the immediate neighbourhood of Cape Town to Ovampoland and from Natal to the Zambesi; where any protection is afforded to it, it becomes exceedingly abundant, and there are large numbers on the Cape Flats and on the farms near Stellenbosch and Malmesbury; north of the Zambesi a steenbok is certainly found, but it is uncertain whether it is this or the allied species (R. neumanni) lately described.

History. - The first definite information published about this little buck is found in Buffon's Supplement, where are quoted descriptions of this and the grysbok as well as of the bleekbok, from a communication received from the Fosters who accompanied Captain Cook on his second voyage of circumnavigation. Buffon rightly, as I think, considered the bleekbok as only of a slight colour variation of the steenbok, in which opinion he was upheld by Thunberg, to whom we owe the Latin names bestowed on both this and the grysbok. Lichtenstein went even further and united all these forms, the steen- grys- and bleek-boks, under one specific name. This, however, is obviously unjustifiable, as there are very distinct structural differences between the two first. Layard and most South African sportsmen still continue to regard the steenbok and bleekbok as distinct animals, but personally the only distinction I have been able to discover is a slight variation in the intensity of the colouration, and I cannot make out that this is in any way geographical.

Habits.-The steenbok is found in open flats with scattered bush, but never in very mountainous or very thickly forested districts. They usually associate in pairs or are found only singly. When disturbed, they make off at a very good pace, galloping high 
and throwing up their quarters at each stride; they seldom go more than a hundred yards or so, however, without looking round, and so giving an opportunity for a shot. Often they lie very close, with their ear's well back, so that, even in comparatively bare country, one can ride within 30 or 40 yards of them. They feed on grass and the shoots of bushes in early morning up till about 9 o'clock, and again in the afternoon after 3 o'clock, sleeping and resting between those hours. They can exist without water for long periods, as is evidenced by the fact that they are found far away in the depths of the Kalahari. One, or more rarely two, young ones are produced during the year, usually in early summer.

In South Africa they are often coursed with greyhounds and afford good sport running either up or down wind; they are said, when hunted, to occasionally go to ground in aard-varks' holes.

In captivity they become tame and gentle, and thrive very well. Their flesh is very palatable, though a little dry.

\section{Raphicerus melanotis. The GrysboK.}

Antilope melanotis, Thunberg, Mem. Acad. Petersb. iii, p. 312 (1811); Lichtenstein, Darstell. Säugeth. pl. xii (1828); A. Smith, Descr. Cat. S. Afr. Mus. p. 22 (1826); Smuts, Enum. Mamm. Cap. p. 82 (1832).

Antilope grisea, G. Cuvier, Dict. Sci. Nat. ii, p. 244 (1816).

Tragulus melanotis, A. Smith, S. Afr. Quart. Journ, ii, p. 213 (1834).

Calotragus melanotis, Sundevall, K. Vet. Akad. Handl. Stockholm, 1844, p. 192 (1846) ; Grill, K. Vet. Aliad. Handl. ii, 2, p. 21 (1858) [Knysna]; Layard, Cat. Mamm. S. Afi. Mus. p. 70 (1861).

Nanotragus melanotis, Brooke, Proc. Zool. Soc. 1872, p. 642; Selous, ibid. 1881, p. 762 [distribution]: Lorenz, Ann. kik. Hofmus. Wien ix notiz. p. 60 (1895) [distribution].

Neotragus melanotis, Rendall, Proc. Zool. Soc. 1895, p. 361 [Eastern Transvaal].

Raphicerus melanotis, P. L. Sclater and O. Thomas, Bk. Antelopes ii, p. 35, pl. xxvii, fig. 2 (1896).

Literature.-Buffon (1782), Suppl. vi, p. 185, earliest description as Grysbok; Thunberg (1793), ii, p. 11, met with this species near Cape Town; Harris (1840), figured on pl. xxvi, fig, 2 ; Nicolls and Eglington (1892) p. 26, pl. viii, fig. 29, description, distribution and habits; Moseley (1892), p. 129, records Grysbok from near Simonstown; Bryden (1893), p. 511, notes as rare in Bechuanaland; Lydekker (1893), p. 219, description ; Kirby (1896), p. 543, native names and habits in the Eastern Transvaal; Ward (1896), p. 117, hor'n measurements; Kirby (1899a), p. 249, range and habits. 
Vernacular Nayes.-Grysbok of the Colonists; Inxunxu of Amaxosa (Stanford); Inhlengana of Swazis; Isikupi of Basutos (Kirby); Sashlungwan of Matabele, Teemba of Makalakas (Selous).

Description.-General form stouter and less slender than the steenbok; general colour grizzled dark rufous brown; the fur long and coarse with a number of pure white hairs interspersed among the red ones causing the grizzled appearance; below paler but not pure white; chin, throat and eyebrow also a dirty white; ears large, broad and rounded, exceeding in length the distance from the front of the eye to the nose-tip, dark grey and nearly naked posteriorly, anteriorly with a few long white hairs, a black or dark Y-shaped mark on the crown usually present; false hoofs present but small and inconspicuous; true hoofs shorter and broader than in the steenbok; tail very short, the same colour as the body. Horns like those of the steenbok, but rather shorter, stouter and more curved forwards. Skull with the antorbital fossa rounded and larger than in the other species.

Dimensions.-From a male ; head and body 30.5 ; tail 1.0 , with hairs 2.0 ; height at shoulder 19.50 ; ear 3.8 ; ear to nose-tip 6.50 skull, length $5 \cdot 20$; breadth $2 \cdot 80$. Horns about 4 inches.

Distribution.-The grysbok is by no means so universally distributed as the steenbok; so far as one can judge it appears to be found only near the sea and in the low-lying districts, and not on the plateaus of the karoo or the high veld of the interior. It is abundant in the neighbourhood of Cape Town and extends along the coast through the Caledon and Knysna districts to Albany and the eastern part of the Coiony, where, however it becomes rare; in the eastern Transvaal it is also rare, though not uncommon in the Limpopo Valley, according to Kirby ; further north, again, it is abundant in north Mashonaland and in the Zambesi Valley, as far as the Victoria Falls, according to Selous. On the other hand it is distinctly stated to be absent from Matabeleland, the high veld of the Transvaal, the Kalahari and German South-west Africa.

I have it recorded by correspondents from the Orange Free State, and in Natal from the slopes of the Drakensberg only.

History.-The early history of the grysbok is the same as that of the steenbok, this animal having been first mentioned in Buffon's "Natural History," and named by Thunberg. Little, however, has been written on the subject since those early days, and my information is chiefly derived from correspondents. 
Habits.-The grysbok is also found in open country, but only where there is plenty of cover and shelter; as a rule it is solitary spending the day in a retired lair or form, from which it is often difficult to dislodge it; it moves with its head low and its pace is not very great, so that it can easily be run down with a good dog; when caught it bleats like a kid. It feeds during the night and early morning, and in the south-western districts of the Colony is specially fond of the tendrils and young shoots of the vine and other fruit trees, in consequence of which it is much execrated by the farmers, and is trapped and shot on all possible occasions. It appears to breed all the year round, but few observations have been made on this point. Its flesh is fair, but not so good as that of the steenbok.

\section{Genus NESOTRAGUS.}

Nesotragus, von Diiben, Oefvers. Akad. Forhandl.

Type.

Stockholm iii, p. 221 (1847)

N. moschatus.

Small antelopes with the rhinarium extending nearly all round the nasal openings, with no auricular glands, accessory hoofs, or knee brushes.

Skull with very large antorbital fossae, which in the male are sharply ridged above and below, in the female are rounded off below, giving the two skulls a somewhat different appearance; vacuities in the skull between the maxillae and premaxillae and further back at the hinder ends of the nasals.

Horns in the males only, slanted back almost parallel to the frontal profile, strongly and finely ridged for at least half their length.

This genus is confined to East and South-east Africa, ranging from Kilima-njaro to Northern Zululand, and is represented by two or perhaps three closely allied species; of these two, if really distinct, are noticed below, the third the Zanzibar antelope $(N$. moschatus) from German and British East Africa is distinguished by its darker and more greyish colour, harsher fur, smaller ears and horns; and by its tail, which is of the same colour as the back. 


\section{Nesotragus livingstonianus. Livingstone's Antelope.}

Antilope moschata, apud Peters, Reise Mozamb. Säugeth. p. 189 (1852) [nec v. Duben].

Nesotragus livingstonianus, Kirk, Proc. Zool. Soc. 1864, p. 657; P. L. Sclater and O. Thomas, Bk. of Antelopes, ii, p. 55, fig. 25 [skull] (1896).

Nanotragus livingstonianus, Thomas, Proc. Zool. Soc. 1893, p. 237 (fig. skull) [Zululand].

Nesotragus livingstonianus zuluensis, Thomas, Ann. Mag. N. H. (7), ii, p. 317 (1898).

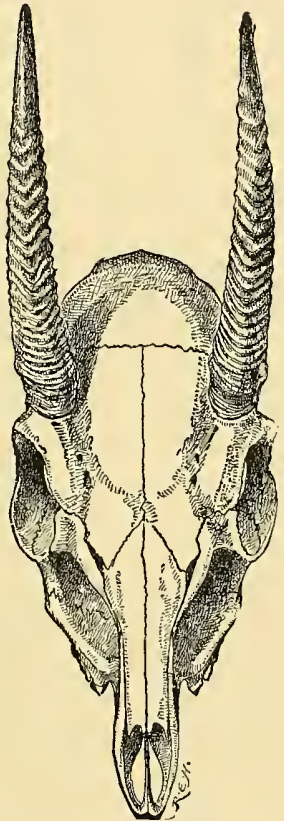

FIG. 49.--Skull of Nesotragus livingstonianus oे

(Proc. Zool. Soc.).

Literature.-Livingstone (1857), p. 209, perhaps alluded to under the name of Tianyane; Lydekker (1893), p. 217, note on; Neumam (Field, vol. lxxx. September, 1898), p. 368, account of distribution and habits of this antelope; Ward (1896), p. 110, holn measurements; Kirby (1899), p. 331, distribution in Mozambique; Kirby (1899a), p. 256, range and habits.

Vernacular Names.-Ithlengane of Zulus (Neumann); Inhlengan at Inhambane (Francis); Rumpsa at Tette (Peters), and Shupanga (Kirk). 
Description.-General colour rich rufous brown, the hairs being tipped with a lighter shade giving a slight speckled look to the animal, paler on the flanks and legs, pure white below and inside the legs; rhinarium extending round the lower side of the nasal opening but not entirely encircling it, a black almost hairless patch along the ridge of the nose extending nearly as far as the eyes; sides of the face and neck paler than the forehead; chin, upper throat and an indistinct eyebrow, white; ears broad, rounded at the tips, very nearly naked within and without, posteriorly dark ashy, anteriorly white; no false hoofs; limbs slender with a black band encircling them just above the hoofs, which are long, pointed and up curved at the tips ; tail longer than in the last genus, almost black above, white below; iris sea green with an outer ring of light brown. Female hornless and with two mammae.

Horns thick and heavy, set in a line with the frontal profile, straight and strongly ringed for three quarters of their length, in the adult male above described there are twenty-three rings.

Dimensions.-From a male measured in the flesh; head and body along curves $27 \cdot 0$; tail 3.5 ; with terminal hairs $5 \cdot 0$; height at shoulder 16.25 ; ear 2.45 ; ear to nose-tip 5.75. Skull, length 4.75 ; breadth $2 \cdot 40$.

Horns average about $3 \cdot 50$, those of the large male in the South African Museum 4.0; Ward records 4.50 .

Distribution.-The range of the Livingstone antelope extends from northern Zululand along the coast to the Zambesi and Nyasaland. It is common near Delagoa Bay, and is often hawked about the streets of Lourenço Marquez by the Kaffirs as venison; from Inhambane further north the South African Museum has a good series of skins obtained for it by Messrs. H. F. and W. Francis. As is pointed out below, the southern race is separated by Mr. Thomas from the typical northern race under the name of N. livingstonianus zuluensis.

History and Yariation.-This little buck was apparently first obtained by Peters during his travels in Mozambique in 1842-8; Sir John Kirk, however, who accompanied Dr. Livingstone on his journey down the Zambesi in 1862 met with another example near Shupanga on that river, and recognised its distinctness from the Zanzibar species with which Peters had identified it and named it after his illustrious travelling companion; recently Thomas, on comparing specimens from northern Zululand with fresh ones from Nyasaland, came to the conclusion that a subspecific distinction 
could be drawn between the two forms owing to the Zululand animal being deep rufous with black fetlocks, while the Nyasaland one is "grizzled fawn colour" with but slight indications of the black on the fetlocks; the example in the Museum from Inhambane seems on the whole referable to the Zululand variety.

Habits.-This little antelope inhabits dense scrub and undergrowth where it is generally found in pairs; it runs like a hare and endeavours to squat and conceal itself in tufts of grass; it feeds chiefly on leaves and young shoots but to a certain extent on grass, and is said to be independent of water. They graze in the forest glades in early morning and late afternoon, resting during the middle of the day under a bush or tree, where they harmonize so exactly with their surroundings that it is impossible to detect them; when beaten up they make off with wonderful speed, twisting and dodging about among the trees; they have three distinct cries, a sharp clear bark like a bush-buck, uttered when suspicious, a sharp whistling snort when put up at close quarters, and a bubbling sound like a he-goat to which the males give vent during pairing time. They are stated to have a very strong musky odour.

\section{Genus MADOQUA.}

\section{Type.}

Madoqua, Ogilby, Proc. Zool. Soc. p. 137 (1836) ........... saltiana.

Antelopes of small size with pointed and somewhat elongated noses almost completely covered with hair, only the nasal septum, which is very narrow, being bare; crown of the head with a tuft of long hairs; tail very short; accessory hoofs present but very minute. Skull with slender and elongated premaxillae and very short nasals, with large shallow antorbital fossae and with the last lower molar in some species without the posterior lobe present in nearly all ruminants.

Horns short, straight or slightly sinuate, strongly ribked basally.

This genus, extending diagonally across Africa from Abyssinia and Somaliland to Damaraland, is essentially one inhabiting dry open country, and is not found in the forest districts of the west and south east.

Six species are generally recognised of which one only reaches our faunal area, and is distinguished from the other five by its greater size, standing over 15 in. at the shoulder, and by its more pointed and developed proboscis. 


\section{Madoqua damarensis. The Damaraland Dik-Dik.}

Neotragus damarensis, Gunther, Proc. Zool. Soc. 1880, p. 20 (fig. skull).

Madoqua damarensis, Thomas, Proc. Zool. Soc. 1894, p. $329 ;$ P. L. Sclater and O. Thomas, Bk. Antelopes, ii, p. 79, fig. 28 [pt. of skull] (1896).

Literature.-Nicolls and Eglington (1892), p. 56, description and distribution; Lydekker (1893), p. 215, note on; Kirby (1899a), p. 266, description.

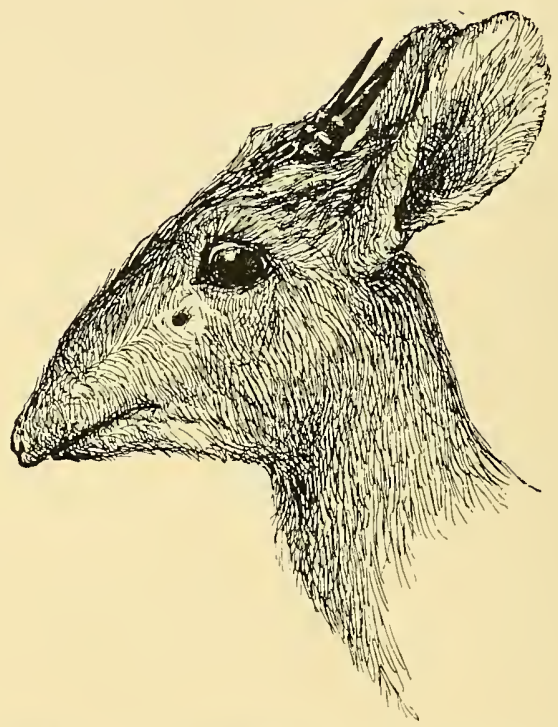

FIG. 50.-Head of the Damaraland Dik-dik (Madoqua damarensis).

Description.-General colour speckled dark grey, the hairs long, pale for the greater part of their length with black subterminal and pale rufous terminal bands; the sides, face, neck, shoulders and flanks want the black and are therefore pale rufous and not speckled, below and inside the legs pure white; nasal opening, except for a small portion of the septum, completely surrounded by hair, the snout being pointed and proboscis-like; chin and a ring round the eye white ; antorbital opening a somewhat semi-lunar slit in a bare patch in front of the eye; a long tuft of straight hairs dark at the base conceals at least half the horns; ears moderate, grey behind, 
a few white hairs inside; limbs slender, pale rufous with small accessory hoofs and very short, compact, triangular true ones; tail very short hardly projecting at all, the same colour as the back.

Female hornless and with two (?) mammae.

Skull with the premaxillae and lachrymals forming a suture, with the naso-frontal suture forming an acute angle directed backwards, and with the posterior lower molars provided with the posterior accessory lobe absent in some of the species of the genus.

Horns stout and tapering, in a line with the frontal profile, with about nine conspicuous rings occupying more than half the length of the horn and with smooth tips.

Dimensions.-Of an old mounted exampie; head and body 26.0 ; tail 1.0 , with hairs 2.5 ; height at the shoulder 15.5 ; ear 2.5 ; from ear opening to nose tip $5 \cdot 50$.

The horns of a male measure $2 \cdot 90$.

Distribution.-The type of this species, a female now in the British Museum, was obtained in 1879 by Mr. Eriksson at Omaruru about forty miles north of Walfisch Bay in German South-west Africa; the South African Museum possesses a male presented by the same collector, and a young male obtained by James Chapman and two flat skins.

It appears probable that the species extends to the southern portion of Angola as evidenced by the collections of Anchieta and van der Kellen.

Nothing regarding the habits of this antelope is recorded except that it inhabits rocky and barren hills near the sea coast, and is difficult to procure owing to its great agility.

\section{Subfamily CERVICAPRINAE.}

Antelopes of large or medium size, with well developed rhinaria and no antorbital glands; false hoofs well developed, horns in the males only, generally ringed and forwardly curved.

\section{Key of the South African Genera.}

A. Tail long and tufted; horns long, and fur coarse... Cobus, p. 184.

$B$. Tail short and bushy.

a. A glandular patch below the ear, fur coarse ...... woolly

Cervicapra, p. 193.

Pelea, p. 199. 


\section{Genus COBUS.}

Kobus, A. Smith, Illustr. Zool. S. Afr. Mamm.

pt. 12, pl. xxviii. (1840)

C. ellipsiprymnus.

Adenota, Gray, Proc. Zool., Soc. 1850, p. 129 ...C. kob.

Onotragus, Gray, Cat. Rum. Bt. Mus. p. 17 (1872).C. leche.

Antelopes of considerable size with naked muzzles and with no antorbital glands; tail long almost reaching the hocks, somewhat tufted at its extremity; false hoofs well developed.

Skull with no antorbital fossae but with a perforation in the middle of the frontal bone at the base of the horn cores into the orbit, and a large lachrymal vacuity between the lachrymal, frontal, nasal and maxillary bones; bulla large and swollen; premaxillae reaching the very long nasals, anterior true molars of each jaw with a median supplementary lobe.

Horns in the male only, curved forwards, lyrate or sublyrate and ringed for the greater part of their length.

This genus is now confined to Africa, south of the Sahara, whence thirteen generally recognised species are known; in addition to these some four or five fossil forms have been described from the pliocene beds of India, China and Algeria showing that the genus had formerly a considerably greater distributional area.

Of the 13 recent species three are South African, and are noticed at length below; the others are as follows:-

C. unctuosus (Laurill.), the sing-sing from West Africa.

C. crawshayi, Scl., Crawshay's waterbuck from Lake Mweru in British Central Africa.

C. penricei, Rothsch., Penrice's waterbuck from South Angola.

C. defassa, Ruppell, the defassa from Abyssinia and East Africa.

C. maria, Gray, Mrs. Gray's waterbuck from the swamps of the White Nile.

C. leucotis (Licht. \& Pet.), the white-eared kob also from the. upper Nile.

C. thomasi, Scl., Thomas' kob from Uganda.

C. kob (Erxl.), Buffon's kob from West Africa.

C. anmulipes (Gray), the kob of later authors also from West Africa.

C. senganus, Scl. \& Thos., the senga kob from North Nyasaland. 


\section{Key of the South African Species.}

$A$. Height at shoulder about $4 \mathrm{ft}$; hair sepiabrown and grizzled

C. ellipsiprymnus, p. 185.

$B$. Fur rufous brown, height at shoulder about $3 \mathrm{ft}$.

a. Legs black in front; horns long, twice the length of the skull

b. Legs not black in front; horns short, not twice the length of the skull

C. leche, p. 189.

C. vardoni, p. 191.

\section{Cobus ellipsiprymnus. The Waterbuck.}

Antilope ellipsiprymnus, Ogitby, Proc. Zool. Soc. 1833, p. 47.

Aigoceros ellipsiprymnus, A. Smith, S. Afr. Quart. Journ. ii, p. 186 (1834).

Kobus ellipsiprymnus, A. Smith, Illustr. Zool. S. Afr. Mamm. pls. xxviii, xxix (1840); Layard, Cat. Mamm. S. Afr. Mus. p. 75 (1861); Lorenz, Ann. kk. Hofmus. Wien ix, notiz. p. 61 (1894).

Cobus ellipsiprymnus, Buckley, Proc. Zool. Soc. 1876, p. 284 ; Selous, ibid. 1881, p. 758 [distribution]; P. L. Sclater, ibid. 1893, p. 505 pl. xxxix [breeding in the Zool. Gardens]; P. L. Sclater and O. Thomas, Bk. Antelopes, ii, p. 97, pl. xxxii (1896).

LtTERAture.-Steedman (1835), ii, p. 94, account of first discovery of the waterbuck with figure; Harris (1838), p. 171, first met waterbuck in the Rustenburg district of the Transvaal ; Harris (1840), figured on pl. xiv ; Delagorgue (1847), i, p. 425, notes as not uncommon in Zululand; Cumming (1855), ii, p. 133, first met this species on the Notwani River, on the northwest frontier of the Transvaal; Drummond (1875), p. 367, habits and shooting; Nicolls and Eglington (1892), p. 44, pl. iv, fig. 12, description, distribution and habits; Bryden (1893), p. 504, distribution; Lydekker (1893), p. 223, description and figure of head; Millais (1895), pp. 120, 147, 189,195 , figures and sketches with notes on habits; Kirby (1896), p. 544, native names and habits in eastern Transvaal; Ward (1896), p. 118, horn measurements ; Kirby (1899), p. 328, distribution in Mozambique; Bryden (1899a), p. 269, range and habits.

Vernacular Names.-Waterbuck of English Colonists, Waterbok or Kring-gat of Dutch; Ipeva of Zulus (Drummond); and Swazis (Kirby); Ipiklwa of Basutos (Kirby); Tumogha of Bechuanas (Selous); Situmogha of Matabele (Nicolls and Eglington); Eetumuha of Makalakas, Eekulo of Masubias (Selous); Mashigi-gig of Makobas and Botletli (Nicolls and Eglington).

Description.-General form thickset; colour a sepia-brown, most pronounced on the face and extremities of the limbs, somewhat paler below, all the hair very coarse and with a somewhat grizzled appearance, owing to its quite light bases and darker tips; in the 
middle of the back is a kind of whorl whence the hairs radiate out in all directions; round the neck the hairs somewhat longer and coarser, though they can hardly be said to form a distinct mane;

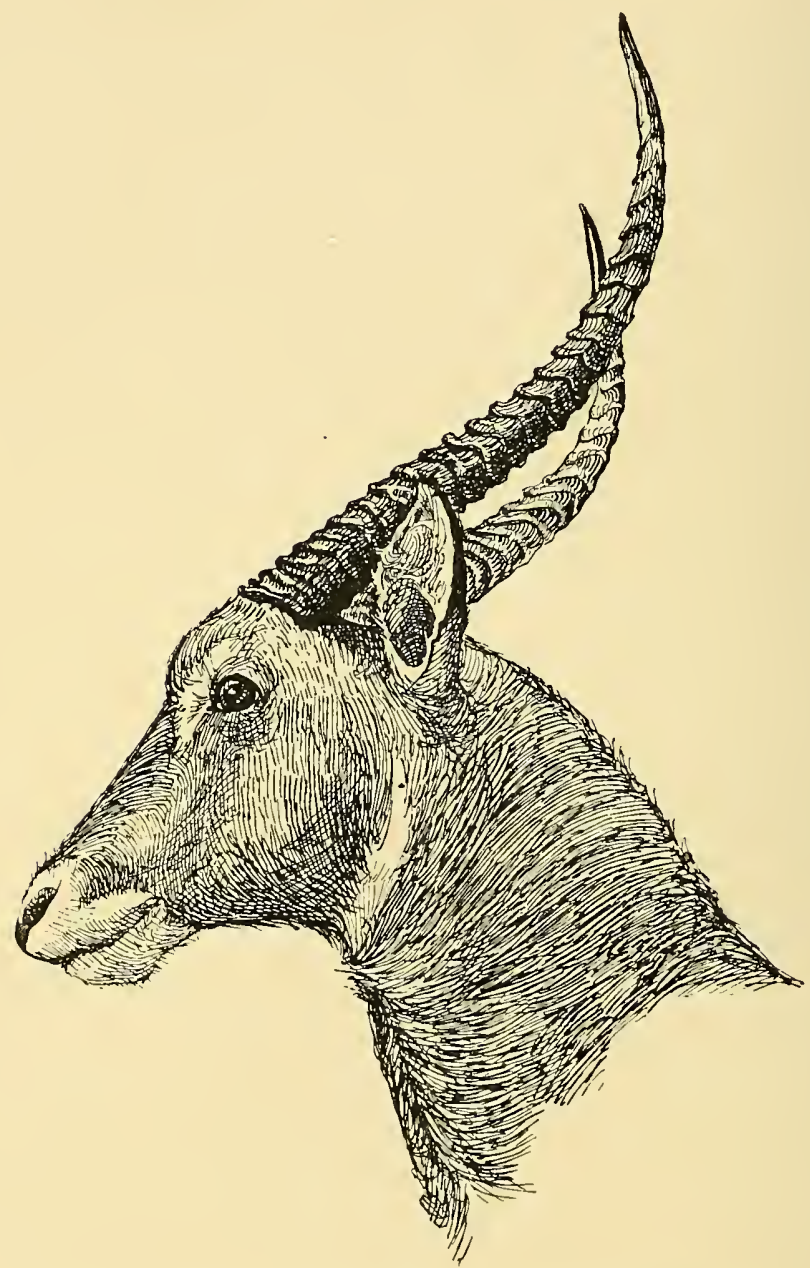

FIG. 51.-Head of the Water-buck (Cobus ellipsiprymmus).

a patch round the nose, the chin, a wide line above and in front of the eye, a narrow line round the throat and another encircling the rump white; rhinarium only between the nostrils, black; ears 
rather short and rounded, brown posteriorly, edged with darker, clothed within with long white hairs; limbs sturdy, false hoofs well developed, true hoofs short, stout and triangular ; tail slightly tufted with dark hairs, almost reaching the hocks.

Female somewhat smaller, with the white stripes and patches not so well marked, and with the hair somewhat longer and more shaggy, especially around the neck; no horns, and four mammae.

Horns large and strong, sublyrate, gently curved backwards and then forwards, strongly ridged and ringed for three quarters of their length.

Dimensions.-From a mounted male; head and body $7 \mathrm{ft.} 4$; tail 15.50 , with terminal hairs 20.0 ; height at shoulder $4 \mathrm{ft.} 2$; of a female $3 \mathrm{ft} .10 .5$; from ear opening to nose-tip 16.0 ; ear from notch $7 \cdot 0$; skull basal length $14 \cdot 75$; breadth $6 \cdot 75$.

An average length for the horns is $28, \mathrm{Mr}$. Selous records 31 from Mashonaland; a pair in the South African Museum obtained many years ago on Lake Ngami, by Chapman, measure 32.5 ; Mr. Roland Ward, however, in his measurements, gives a record of 36.5 of a pair from near Delagoa Bay in the possession of Mr. Barber.

Distribution.-The waterbuck is not found within the limits of the Cape Colony proper, but from the Limpopo River northwards it becomes fairly abundant; it is met with in the northern part of German South-west Africa, i.e., Ovampoland, in Matabeleland and Mashonaland, especially along the Botletli River and near Lake Ngami ; it is very common throughout the Portuguese territories as far south as Zululand, and Kirby states it is exceedingly abundant in the low country of the eastern part of the Transvaal. Beyond our limits the waterbuck is plentiful throughout Nyasaland, German and British East Africa and as far north as the Shebeyli River in Somaliland.

The South African Museum possesses a fine mounted pair obtained by Mr. Selous, the male at Macloutsie in the Bechuanaland Protectorate, the female on the Hanyani River in Mashonaland as well as skulls from Lake Ngami, the Beira district and North Nyasaland.

History. - Although the waterbuck was vaguely known to exist even before the Cape finally passed into the hands of the English, the first specimen, a much mutilated skin, was obtained by means of the offer of a large premium by the Governor, Sir Lowry Cole (1828-34), and it was on this specimen that Sir Andrew Smith drew 
up his earliest description. In the meantime, however, a Mr. A. Steedman, an African traveller, took to England a complete specimen on which Ogilby founded his description and the Latin denomination which it has since borne. Steedman's example is said by him to have come from the "West of Latakoo twenty-five days north of the Orange River," which would be somewhere on the edge of the Kalahari desert, a somewhat unlikely locality, and probably accounted for by the fact that this traveller does not appear to have ever reached so far north, and that he obtained his example from natives or traders; neither Smith, Harris nor Gordon Cumming, at any rate, met with the waterbuck till they reached the head waters of the Limpopo and its affluents, a good deal further north; Smith as above-mentioned, Selous and Kirby all give good accounts of this animal which is now very well known.

Habits.-Waterbucks, as their name implies, are always found fairly near water; as a rule they go in herds numbering usually ten to fifteen individuals, though sometimes when the animal is abundant the herds are much larger. They seem fond of rough and broken country and the sides of steep shady bills near rivers and streams to which, as a rule, they make off if disturbed. The herds nearly always contain a very large proportion of females with a few old males, the other males either congregate by themselves or are found solitary. While feeding, which they do in the early morning and evening, the ewes, according to Millais, keep guard with ears playing backwards and forwards and eyes equally alert for the approaching enemy. Although appearing heavy and clumsy animals their pace is considerable, especially on rough ground across which they make their way with great agility. When wounded and taking refuge in reedbeds or similar shelter they have been known to be very dangerous, charging fiercely with their horns.

Every one is agreed that the flesh of the waterbuck is almost uneatable, as it is so very coarse and strong, besides being endowed with a very powerful and disagreeable scent, easily perceptible even during life.

Mr. Selous further relates that when in good condition the fat of the meat is peculiarly sticky, clogging the teeth and making it impossible even for a hungry man to make a meal.

The waterbuck is not often seen in Europe, but a pair in the Zoological Gardens of London from British East Africa, presented by Mr. G. S. Mackenzie, bred in 1893, and a young female, born in the Gardens on May 4, was the first instance so far as is known of such an occurrence in captivity. 


\section{Cobus leche. The Lechwe.}

Adenota leche, Gray, Proc. Zool. Soc. 1850, p. 130, pl. xx; Layard, Cat. Mamm. S. Afr. Mus. p. 75, (1861).

Kobus leche, Gray, Knowsley Manageric, p. 23 (1850).

Heleotragus leche, Kirk, Proc. Zool. Soc. 1864, p. 658.

Cobus lechee, Buckley, Proc. Zool. Soc. 1876, p. 291 ; Selous, ibid. 1881, p. $760 ;$ P. L. Sclater and O. Thomas, Bk. Antelopes, ii, p. 149, pl. xlii \& fig. 36 [woodcut of head] (1897).

Literature.-Oswell (1851), in Journ. R. Geogr. Soc. xx, p. 150 and Livingstone (1851), in Journ. R. Geogr. Soc. xxi, p. 23 give the earliest account of the lechwe; Andersson (1856), p. 448, pl. xiii, occurrence on Lalie Ngami ; Livingstone (1857), p. 71, seen and described for the first time on Lake Ngami in 1849, p. 204, occurrence on the Zambesi ; Chapman (1868), p. 141, habits and occurrence on the Botletli River; Selous (1881), p. 137, habits and occurrence on the Chobe River in 1874; Nicolls and Eglington (1892), p. 42, pl. vii, fig. 22, description, distribution and habits; Selous (1893), p. 450 , account of habits on the Chobe; Bryden (1893), p. 315 on the Botletli River, p. 362.4 on its habits and structure, p. 506, distribution; Lydekker (1893) p. 225, note on, with figure of head; Oswell in Badminton Big-game shooting (1894), i, p. 122, account of the first discovery and of habits; Ward (1896), p. 125, horn measurements ; Gibbons (1897), p. 398, distribution in Barotse country; Selous (1899), p. 299, range and habits.

Vernacular Names.-Lechee or Leegwee of the Makalolo, Inya of the Masubias (Selous).

Description.-A little smaller than the waterbuck with the hair firmer and less coarse; general colour a fulvous-brown darkest along the back, becoming lighter on the sides and white below and on the insides of the legs; white marks also present round the eyes, at the base of the ears, along the upper jaw and from the chin and throat to the breast; ears moderate, pale brown posteriorly with a few long white hairs inside and no brown tips; front limbs with a dark almost black band running down the front of the leg to the hoofs, darkest above the knee; hind limbs with the dark marks only extending a short way above the hoofs; just above the hoofs are white rings, but these vary considerably in development, and are often hardly discernible; false hoofs well developed, true hoofs somewhat elongated and pointed, the space between them (i.e., the pasterns) being quite naked, a character which distinguishes this species from all other waterbucks; tail reaching to about the hocks the same colour as the body with a tuft of long black hairs at the end.

The female closely resembles the male but is a little smaller, 
with no horns and four mammae. The young males have black tips to the ears like the adult pukus.

Skull considerably smaller than that of the waterbuck, with much smaller nasals, which are not reached by the premaxillae, and with very much smaller lachrymal vacuities.

Horns more curved than in the waterbuck, the lower third curving outwards, the middle thirds almost parallel to one another and the tips bent forwards almost at a right angle, very strong, ringed to within a few inches of their tips, black, with the ridges somewhat paler, the tips quite smooth and black.

Dimensions.-From a mounted specimen; head and body $6 \mathrm{ft} .2$; tail 10, with terminal hairs 15 ; height at shoulder 38 , of a female, 36 ; from ear to nose-tip 12.50; ear from notch $5 \cdot 50$. A skull measures about 12.5 in basal length, and 5.40 in greatest breadth. Average horns are about 24 to 26 inches; Selous records 27 and Ward 28.5; the latter measurement from a pair of horns in Mr. F. H. Barber's possession.

Distribution.-The lechwe is found within our area only in Lake Ngami and on the river flowing out of it, called formerly the Zouga, now better known as the Botletli; it is also met with in the upper waters of the Zambesi and its affluent the Chobe. North of the Zambesi Selous obtained this waterbuck on the swamps of the Lukanga river, 150 miles south-west of Lake Bangweolo, and Mr. A. Sharpe has met with it on Lake Mweru; this is the most northerly extension hitherto recorded.

History.-This species was first discovered on the banks of the Zouga or Botletli River by Livingstone and his two companions, Oswell and Murray, who travelled with him in 1849 on his first journey to Lake Ngami. An example was sent home to England by Oswell to Captain Vardon, and was exhibited by him at a meeting of the Zoological Society, on June 11th, 1850; thus the species came to be included in a "Synopsis of Antelopes and Strepsiceres," read by Gray before the Society the same evening, and was also included in the "Gleanings from the Knowsley Menagerie," by the same author, who, however, perhaps unintentionally, makes it appear that Captain Vardon and not Oswell was responsible for the discovery; our subsequent knowledge of this animal is chiefly due to the observations of Mr. Selous.

Habits.-After the sitatunga (Tragelaphus selousi) this is doubtless the most water-loving and aquatic in its habits of all antelopes; it is usually found knee, or even belly deep in water, among the reeds and papyri, in considerable herds, consisting sometimes 
of females with only a few old males, at other times of males only. When disturbed the males stretch their horns back flat along their sides and trot away; if further pressed they break into a kind of lumbering gallop, even when the water is up to their necks they move by tremendous leaps and bounds accompanied by a great deal of splashing; on reaching deep water they swim well and strongly, though not so fast as a native can paddle; in winter when the country is flooded, advantage is frequently taken of this to drive them into the deep water when they are mercilessly assagaied.

Selous, as well as other observers, remarks on the great tenacity of life shown by these antelopes, as well as the puku. The skin is in very great request among the natives for karosses, and the flesh is said to be less distasteful than that of other waterbucks.

\section{Cobus vardoni. The Puku.}

Antilope vardoni, Livingstone, Miss. Trav. p. 256 [plate on p. 71] (1857).

Heleotragus vardonii, Kirk, Proc. Zool. Soc. 1864, p. 657.

Cobus vardoni, Selous, Proc. Zool. Soc. 1881, p. 759, pl. lxv; P. L. Sclater and O. Thomas, Bk. Antelopes, ii, p. 141, pl. xli \& fig. 35 [holns] (1897).

Literature.-Selous (1881), pp. 111, 130, 147, pl. v, on localities and habits, Nicolls and Eglington (1892), p. 43, pl. viii, fig. 30, description, distribution and habits; Lydekler (1893), p. 227, note on; Ward (1896), p.129, horn measurements; Selous (1899), p. 294, range and habits.

Vernacular Names.-Poku or Puku throughout its range; Impookoo of Masubias (Selous).

Description.-A good deal smaller than the waterbuck; general colour a rich orange yellow, a little paler round the eyes on the chin and lower surface of the body; a small tuft of black hairs marks the opening of the antorbital gland; ears with long, white hairs within, posteriorly pale fulvous with well-marked black tips; no whorl of hairs in the middle of the back; on the fore and hind limbs is an indistinct patch of black just above the hoofs, but there is no marked black stripe in front of the legs as in the lechwe; space between the false and true hoofs, i.e., the pasterns, hairy; true hoofs triangular and stout, not elongated, false hoofs large; tail short and slender, the same colour as the back with a small terminal black tuft.

Horns stout with a slight forward and outward curve at the base 
and with the tips directed forwards, strongly ridged and ringed for three-fourths of their length.

Dimensions.-From a mounted male; head and body $5 \mathrm{ft.} 9$; tail $7 \cdot 5$; with terminal hairs $10 \cdot 0$; height at shoulder $2 \mathrm{ft.} 11$; ear 5 ; ear to nose-tip 12. A skull measures, length $11 \cdot 0$; breadth 4.47 . Horns measure about 15 to 16 inches; Selous in "Great and Small Game" records a pair measuring 20.25 from the neighbourhood of Lake Bangweolo.

Distribution.-This antelope is found in the upper part of the Zambesi Valley and in its affluents, especially the Chobe, and extends northwards through the Barotse country as far as Lake Mweru.

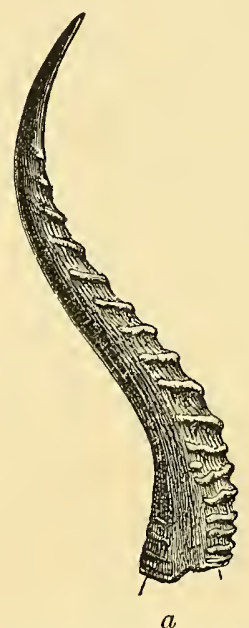

FIG. 52.-Horns of the Puku (Cobus vardoni) : $a$, side view; $b$, front view. (Proc. Zool. Soc.).

An allied form (Cobus senganus, P. L. Sclater and Thos. Bk. Antelopes, ii, p. 145) has recently been described from the country between Lake Mweru and Lake Nyasa but will very probably be found to be indistinguishable from the puku.

The South African Museum possesses a mounted male from Barotseland presented by Major Coryndon.

History.-This waterbuck was first discovered and named by Livingstone on the Zambesi in the neighbourhood of Libonta in the Barotse country far above the Victoria Falls in 1853 ; it is figured. 
together with the lechwe, in a plate purporting to be a view of the River Zouga or Botletli, but there is no evidence to show that Livingstone or any subsequent traveller found it so far south.

For nearly all our subsequent knowledge of this antelope we are indebted to $\mathrm{Mr}$. Selous.

Habits.-The puku is decidedly less aquatic than the lechwe; it may generally be seen 200 to 300 yards away from the river cropping the short grass or lying in the shade; it is found in herds of three to four dozen individuals of both sexes, though at times the rams run by themselves; Selous states that he never saw mixed herds of lechwe and pukus, but this is not borne out by other observers, as Mr. A. Sharpe speaks of lechwes and pukus running together in enormous herds in the Mweru and Luapula countries.

The flesh of the puku is stated by Selous to be even more nauseous and unpalatable than that of the common waterbuck.

\section{Genus CERYICAPRA.}

Cervicapra, Blainville, Bull. Soc. Philom. p. 75 (1816) ..........................................

Redunca, H. Smith, Griff. An. Kingd. v. p. 337 (1827) Eleotragus, Gray, List Mamm. B.M. p. 165 (1843) ...C. arundinum.

Type.

C. redunca.

The animals comprising this genus resemble the waterbucks in most respects, but, are of smaller size and have very bushy short tails; they are further provided with a glandular and generally naked spot on the side of the head just below the ears.

The skull is light with large lachrymal vacuities and no antorbital fossae, the premaxillae hardly reach the nasals; the horns are present only in the males and are curved forward and upwards.

Except for one extinct species from the pleistocene beds of Algeria this genus is confined to Africa south of the Sahara whence five species are generally recognised. Of these, two come within our limits, the others are :-

C. bohor (Rupp.), the bohor, from Abyssinia and East Africa, closely allied to the Cape Reedbuck.

C. redunca (Pall.), the nagor, from Senegal and Gambia in West Africa.

C. chanleri, Rothschild, Chanler's reedbuck, from British East 
Africa closely allied to if not identical with C. fulvorufula, the South African rooi rhebok.

\section{Key of the South African Species.}

A. Size larger, height at shoulder about 34 in., yellowish brown, homs about $12 \mathrm{in.}$ C. arundinum, p. 194.

$B$. Size smaller, height at shoulder about 28 in., greyish brown, horns about $5 \mathrm{in.}$

C. fulvorufula, p. 197.

\section{Cervicapra arundinum. The Reed-BUCr.}

Antilope arundinum, Boddaert, Elench. Anim. p. 141 (1785).

Antilope eleotragus, Schreber, Säugeth. pl. cclxvi (1787); Thunberg, Mem. Acad. Petersb. iii, p. 314 (1811).

Antilope cinerea, Bechstein, Syst. Uebers. vierf. Thier. ii, p. 643 (1800). Antilope isabellina, Afzel, N. Act. Ups. vii, p. 250 (1815).

Redunca isabellina, Smuts, Enum. Mamm. Cap. p. 75 (1832); A. Smith, S. Afr. Quart. Journ. ii, p. 210 (1834).

Redunca eleotragus, A. Smith, S. Afr. Quart. Journ. ii, p. 210 (1834).

Eleotragus arundinaceus, Layard, Cat. Mamm. S. Afr. Mus. p. 74 (1861).

Cervicapra arundinacea, Selous, Proc. Zool. Soc. 1881, p. 758 [distribution]; Lorenz, Ann. kk. Hofmus. Wien ix, notiz. p. 61 (1894).

Cervicapra arundinum, Rendall, Proc. Zool. Soc. 1895, p. 358; P.L. Sclater and $O$. Thomas, Bk. Antelopes, ii, p. 157, pl. xliii \& fig. 37 [horns] (1897).

Literature.-Buffon (1782), Suppl. vi, p. 187, earliest mention of the Reedbuck, with plate from Allamand; Sparrman (1785), ii, p. 240, met with Reedbuck only once in Somerset East; Barrow (1801), p. 87, met with this species near Algoa Bay; Harris (1838), p. 165, shot the species in the north-west Transvaal; id. (1840), figured on pl. xxvii, fig. 2; Grout (1863), p. 398, habits and native names in Natal ; Drummond (1875), p. 397, account of habits and hunting in Natal; Nicolls and Eglington (1892), p. 36, pl. vii, fig. 23, description, distribution and habits; Bryden (1893), p. 507, distribution; Lydekker, (1893), p. 227, note on ; Millais (1895), pp. $107,108,113$, distribution with sketches and note on the soft horn bases; Kirby (1896), p. 545, native names, habits and distribution in the Eastern Transvaal; Ward (1896), p. 134, horn measurements; Millar, Zoologist (4), iii (1899), p. 146, care of young; Kirby (1899), p. 328, distribution in Mozambique; Kirby (1899a), p. 305, range and habits.

Vernacular Names.-Peedbuck of English, Reitbok of Dutch Colonists; Inthlangu of Amaxosa (Stanford), of Zulus (Drummond) and of Swazis (Kirby), also Imsigi or Umzibi of Zulus (Stanford) and Matabele (Selous); 
Iklabu of Basutos (Kirby), Cipohata of the Bechuanas (Nicolls and Eglington); Eebeepa of Makalakas, Imvwee of Masubias and Bemba of Masarwas (Selous).

Description.-General colour a slightly speckled fulvous brown, the hairs being dark brown at the base and yellow at the tip; the colour is darkest on the back, and becomes paler, sometimes quite white, below, as well as on the insides of the limbs, on the sides of the face and round the lips; black markings on the face usually absent, but a black patch on the nose in some specimens and on the crown in others; on the nose is a rounded swelling not often seen in mounted specimens, but very well shewn in Millais' sketches of the fresh-killed animal; ears moderate, fulvous posteriorly, clothed inside with the usual long white hairs; about an inch below the ears is the oval glandular patch bare in the adult, clothed with fine white hairs in the young; round the neck the hair is somewhat lengthened but hardly forms a mane; fore limbs with well marked black stripes running down their fronts and encircling them just above the hoof, hind limbs with less well marked stripes not reaching the hocks, false hoofs well developed, true hoofs triangular and pointed; tail reaching about halfway to the hocks exceedingly thick and bushy, fulvous above, white below, the colours strongly contrasted.

Female like the male, but a little smaller and without horns.

Horns divergent, curved backwards and upwards, forming an even quarter of a circle, ringed for about two-thirds of their length, the soft growing pad at their bases, which in most species is absorbed at maturity, here remains persistent through life as a rounded fleshy swelling, though in some cases this space, about two inches wide, becomes hard and longitudinally corrugated, according to Kirby.

Dimensions.-Of a mounted male; head and body $4 \mathrm{ft.} 5$; tail 7 , with terminal hairs 9.50 ; height at shoulder 34.5 , of a female $29 \cdot 0$; ear from notch $5 \cdot 75$; ear opening to nose-tip 10.50. Skull basal length $10 \cdot 50$; breadth 4.75 .

Horns average 12 to 13 inches in length ; the longest pair mentioned by Ward are $16 \frac{3}{8}$ in. in length, obtained by Major Trollope in British Central Africa, the longest pair from South Africa measure $15 \frac{7}{8}$ and are in the possession of $\mathrm{Mr}$. C. D. Rudd.

Distribution.-The reedbuck never appears to have been found in the western part of the Colony, but in the eastern districts along the river valleys it was common in the earlier days, and is 
still to be obtained, though somewhat rarely, in the divisions of Bathurst, Komgha, and Tembuland; from Natal and Zululand onwards, it is common in the low country up to the Zambesi, along the East Coast rivers and their affluents, especially those of the Limpopo and Zambesi, and thence it extends over the greater part of Rhodesia, Ngamiland and the Transvaal low country. It reappears again in Ovampoland. Beyond our limits it occurs on the West Coast as far as Angola and on the East to Nyasaland and Mozambique.

The South African Museum possesses examples from Beira, Damaraland and Nyasaland.

History.-As can be seen by the long list of synonyms there has been a good deal of obscurity and confusion regarding this antelope. It was first brought to the knowledge of Europeans by the Dutch Naturalist, Allamand, who derived his notes and drawings from Colonel Gordon, a Scotchman, in the service of the Dutch East India Company. On Buffon's copied account from Allamand, Boddaert and Schreber founded their Latin names as given above, of which Boddaert's has priority. Among modern writers Millais has noticed and described several points passed over by previous naturalists.

Habits. - The reedbuck lives always in grassy or reedy valleys in the neighbourhood of streams and vleys; according to Selous it is very reluctant to enter or cross water, crouching and taking refuge in the thick vegetation along the margins of rivers; Kirby, however, states that it takes to water very readily, swimming with great vigour and avoiding pursuit by sinking itself in some deep waterhole so that only the nostrils appear on the surface.

As a rule not more than three or four individuals are found together, i.e., a male, female, and one or two young ones. Most sportsmen have noticed that when distressed, this buck gives vent to a loud and characteristic whistle. Their pace is not very great; they move over good or bad ground indifferently with a slow, rolling gallop, and in consequence of their habit of standing to look round after they have gone a short distance are easily shot; when in shelter they lie very close, squatting flat on the ground almost like a rabbit, an attitude which is very well depicted in one of Millais' sketches. Their food consists solely of grass.

The flesh of the reedbuck is described by most writers as "scarcely palatable"; Kirby states that he regards a well-larded leg as a real delicacy, so that statements on this point are contradictory. 


\section{Ceryicapra fulyorufula. The Roor Rhebol.}

Antilope fulvorufula, Afzel, N. Act. Ups. vii, p. 250 (1815).

Antilope lalandia, Desmontins, Dict. Class. d'Hist. Nat. i, p. 445 (1822).

Redunca eleotragus, apud Smuts, Enum. Mamm. Cap. p. 75 (1832) [nec Schreb.].

Redunca lalandii, A. Smith, S. Afr. Quart. Jour. ii, p. 210 (1834).

Eleotragus reduncus, apud Layard, Cat. Mamm. S. Afr. Mus. p. 74 (1861) [nec Pall.].

Cervicapra redunca, Gunther, Proc. Zool. Soc. 1890, p. 604, fig. i, [cranial characters].

Cervicapra lalandii, Rendall, Proc. Zool. Soc. 1895 p. 359.

Cervicapra fulvorufula, P. L. Sclater and O. Thomas, Bk. Antelopes, ii, p. 175, pl. xlv \& figs. 41-2 [horns] (1897); Thomas and Kirby, Proc. Zool. Soc. 1897, p. 694 [on an albinoid variety].

Literature.-Buffon (1782), Suppl. vi, p. 188, noticed by Allamand as a smaller variety of the Reedbuck; Harris (1838), p. 215, shot in the Pretoria district of the Transvaal; Delagorgue (1847) p. 473, account of an individual shot in Zululand; Drummond (1875), p. 398, note on its occurrence in Natal ; Bryden (1889), p. 298, account of habits and distribution in the Colony; Nicolls and Eglington (1892), p. 34, pl. i, fig. 4, description, distribution and habits; Bryden (1893), p. 510, distribution in Bechuanaland; Lydekker (1893), p. 228, note on; Millais (1895), p. 188, shot in south-east Mashonaland; Kirby (1896), p. 546, native names and habits in eastern Transvaal; Ward (1896), p. 132, horn measurements; Kirby (1899a), p. 314, range and habits with account of Lydenburg albinoid race.

Vernacular Names.-Rooi Rhebok of the Colonists; Inxala of Amaxosa (Stanford) ; Inhlang' amatshe (Reedbuck of the rocks) of Swazis and Zulus (Kirby).

Description.-Smaller than the reedbuck; general colour, grey, brown, or fawn, hair long and somewhat soft and woolly, below together with the inside of the fore and hind limbs pure white; face, especially the forehead, fulvous with a somewhat indistinct black mark along the top of the nose; ears long and narrow almost equalling the horns with the usual long white hairs inside; the glandular spot below the ear is only marked by shorter hairs and is not conspicuous; limbs dark but with no defined black markings; hoofs very small and short; tail like that of the reedbuck short and very bushy, grey brown above, white below. Female similar to the male, but hornless, and with two mammae. Horns very short, the basal half ringed, the terminal half smooth, evenly curved forwards. 
Dimensions.-From a mounted male; head and body 4 ft. 2 ; tail 6.50 , with terminal hairs 9.0 ; height at shoulder 27.0 ; ear from notch $5 \cdot 75$; ear to nose-tip $9 \cdot 0$; skull length 8.65 , breadth 4.20 . Horns measure from 5 to 6 inches in length; the record given by Ward is $7 \frac{3}{4}$.

Distribution.-The rooi rhebok is found all over the eastern half of the Colony, extending westwards as far as the divisions of

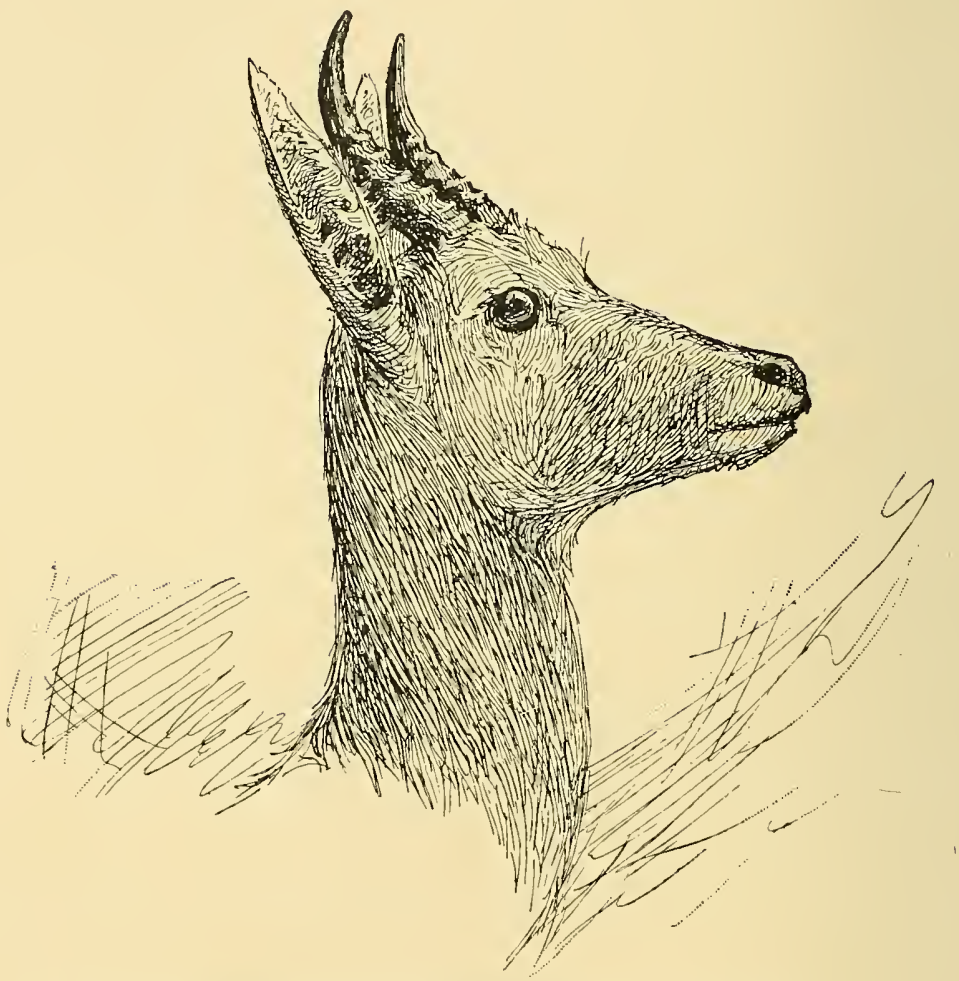

FIG. 53.-Head of the Rooi Rhebok (Corvicapra fulvorufula) $\delta$.

Prince Albert, Beaufort West and Carnarvon; beyond the Colony it is stated to be found through Natal, Zululand, the Free State, Swaziland, the Transvaal and Bechuanaland, but it does not seem to be known from north of the Limpopo, and is, therefore, absent from Rhodesia. 
The South African Museum possesses a good mounted pair from near Burghersdorp in the Colony, the male of which has been figured in the Book of Antelopes, and a skull from Barberton in the Transvaal.

History and Yariation.-Like the reedbuck this species was first brought to the notice of European naturalists by Allamand, and on his account was founded the Latin name here adopted as being the oldest given; there has always been a good deal of confusion regarding this antelope, some of the earlier writers regarding it as merely a smaller variety, or even the young of the reedbuck, but there is no doubt that it is quite distinct.

Mr. Kirby has recently described a very curious albinoid variety discovered by him on a range of hills, the Steenkampberg near Kruger's Post in the Leydenburg district of the Transvaal ; in this form the legs are white from the knees downwards, the hoofs, the tail above as well as below, a spot on the forehead and a line along the middle of the back are also all white; a considerable herd of these all agreeing with one another in this curious coloration were found by $\mathrm{Mr}$. Kirby on the top of the mountain, whence several specimens now in the British Museum were obtained and preserved.

Habits.-The rooi rhebok is found on the dry stony slopes of hills, not usually on the top but on the bushy sides just below the krantzes; as a rule they associate in small parties of four to eight individuals, and when feeding or resting post a sentinel, usually an old ram, who keeps a sharp look-out, and on the approach of danger gives the alarm by a shrill whistle. When disturbed they make off with a free, easy gallop, but can often be again brought to a stand by a sharp whistle. As they run their bushy tails are thrown up so as to show the underlying white. Their flesh is good eating. They are entirely grass-feeders, and drink once a day. The young are born between October and December.

\section{Genus PELEA.}

\section{Type.}

Pelea, Gray, Proc. Zool. Soc. 1850, p. 126................ capreolus.

Antelopes of moderate size, with woolly fur of peculiar texture, with a very large and swollen rhinarium, extending a considerable distance back behind the nasal openings, and with no sub-auricular glandular patches.

Skull resembling that of Cervicapra, with no antorbital fossae, 
and with short premaxillae not reaching the nasals ; the bullae are small and the lachrymal fissure is very narrow and little developed.

Horns of medium length, nearly vertical, slender, ringed and straight or slightly bowed forwards. Only one species is recognised, that described below, confined to South Africa.

\section{Pelea capreolus. The Vaal Rhebol.}

Antilope capreolus, Bechstein, Syst. Uebers. Vierf. Thiere i, p. 98 (1799); Thunberg, Mem. Acad. Petersb. iii, p. 312 (1811); Lichtenstein, Darstellung Sëugeth. pl. viii (1827).

Antilope lanata, Desmoulins, Dict. Class. d'Hist. Nat. i, p. 445 (1822).

Antilope villosa, Burchell, Travels ii, p. 302 (1824).

Redunca capreolus, Smuts, Enum. Mamm.Cap.p. 77 (1832); A. Smith, S. Afr. Quart. Journ. ii, p. 107 (1834).

Pelea capreolus, Gray, Cat. Ung. B. M. p. 90, pl. xxxvi, fig. 2 「skull] (1852) ; Layard, Cat. Mamm. S. Afr. Mus. p. 73 (1861); Lorenz, Ann. kik. Hofmus. Wien ix, notiz. p. 60 (1894); Rendall, Proc. Zool. Soc. 1895, p. 360 [Transvaal]; P. L. Sclater and O. Thonas, Bk. Antelopes, ii, p. 189, pl. xlvi and fig. 44 [head] (1897).

Litenature.-Masson (1776), p. 270, early mention of the rhebol; Sparrman (1789), ii, p. 239, short notice of rhebok; Moodie (1835), i, p. 284, habits and occurrence in Swellendam; Harris (1838), p. 214, shot in the Pretoria district of the Transvaal; Harris (1840), figured on pl. xxv, fig. 1 ; Gray (1850), p. 12, pl. xii, fig. of young and head; Drummond (1875), pp. 370, 396, habits and hunting in Natal; Bryden (1889), p. 125, on habits and shooting in the Colony with plate; Nicolls and Eglington (1892), p. 33, pl. vii, fig. 24, description, distribution and habits; Moseley (1892), p. 129, occurrence near Simonstown; Bryden (1893), p. 510, found in the Bechuanaland hills; Lydekker (1893), p. 220, description and habits; Kirby (1896), p. 544, habits and native names in the eastern Transvaal; Ward (1896), p. 130, horn measurements ; Kirby (1899a), p. 319, range and habits.

Vernacular Names.-Rhebok or Vaal Rhebok of the Colonists; Thula (Cloete), Mliza (Stanford) of Amaxosa; Iliza of Swazis and Zulus (Kirby); Pshiatla of Basutos (Kirby); Peeli of Bechuanas (Burchell).

Description.-Form slender and graceful ; general colour greybrown, with a somewhat fulvous tinge on the legs and face, below to the tail pure white; fur short, soft, thick and woolly, somewhat like that of a rabbit, with sub-terminal brown and terminal pale tips; rhinarium very large, extending backwards and much swollen ; an indistinct ring round the eye ; chin with a black transverse band; throat white; ears very long, narrow and pointed; no antorbital 
gland as in the reedbucks; neck long and slender; legs somewhat darker in front; false hoofs present; true hoofs short, triangular and compact; tail short, reaching to about the groin; basally the same colour as the back, terminally and below white.

Female resembling closely the male, but hornless and with two mammae.

Horns set almost at a right angle to the facial profile, slender and nearly straight, ringed for a little more than half their length.

Dimensions.-From a mounted specimen; head and body $4 \mathrm{ft}$.; tail 3.50 , with terminal hairs 6.50 ; height at the shoulders 29.0 ; ear from the notch 6.5 ; from ear to nose-tip 8.5 ; skull length 8.20 , breadth $4 \cdot 10$.

The average length of the horns is about 8 , but there are a pair in the South African Museum from the Caledon Division measuring $10 \frac{1}{2}$, and Ward records a pair attaining a length of $11 \frac{1}{2}$ from Spitzkop in the Eastern Transvaal.

Distribution. - The rhebok is widely spread everywhere in Africa, south of the Limpopo, wherever there is suitable ground; although mentioned in the Book of Antelopes as inhabiting Matabeleland and Mashonaland I have not heard of its occurrence there, nor is it mentioned by Selous.

In the Colony it is found nearly everywhere, and is often met with on Table Mountain and on the range running southwards to Cape Point; in Natal and Zululand it occurs in the Drakensberg, and westwards of this through the Republics to Great Namaqualand.

In the South African Museum are a mounted pair, the male from the Worcester, the female from the Caledon division of the Colony.

History. - The earliest mention of the rhebok, so called by the Colonists from its fancied resemblance to the roe-buck or roe deer of Europe, is to be found in Masson and Sparrman's travels, and on the latter's description, Bechstein, in 1799, founded the name it now bears; later on Desmoulins redescribed the same animal from specimens transmitted to Paris from the Cape by Delalande and again Burchell, when he met with the species in Bechuanaland bestowed on it a third name. I am indebted to Dr. C. L. Lindley for some observations on the habits of this animal.

Habits. - The rhebok is always found on the flat tops or near the top of the mountain ranges and hills found almost all over South Africa; from these it seldom descends except occasionally to obtain water. It is generally seen in small family parties of six to ten 
individuals led by an old ram. When resting or feeding a sentinel is posted on a neighbouring hillock or kopje who gives the alarm with a sharp snort or cough, on which the troop make off, headed by the old ram, usually in a predetermined course, so that if this is known it is not difficult to cut them off and get an easy shot; their pace is not very great and consists of a peculiar gallop, during which the hind quarters are constantly jerked up in the air, giving one the impression, says Dr. Lindley, that they are lame in the hind leg; furthermore when they run off they always keep their tails erect showing the underlying white.

They feed in the early morning, chiefly on grass, and they usually produce two young at a birth; they are seldom seen in captivity, only four having ever reached the Zoological Gardens in London.

The meat is dry and not very palatable; it is sometimes rejected by the Dutch farmers in consequence of the number of botfly larvae found, at certain seasons of the year, lying between the skin and the flesh.

\section{Subfamily ANTILOPINAE.}

Antilopes of medium or small size with hairy muzzles, the rhinarium being greatly restricted; tail short; two mammae; horns lyrate and ringed, sometimes absent in the females.

\section{Key of the South African Genera.}

A. No false hoofs ; tufts of hair on the hind legs ........Aepyceros, p. 202.

B. False hoofs present; no tufts on the hind legs.........Antidorcas, p. 208.

\section{Genus AEPYCEROS.}

Aepyceros, Sundcvall, K. Vet. Akad. Handl. 1845,

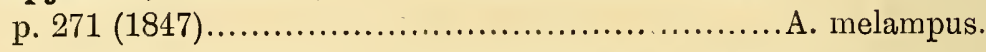

Antelopes of median size with slender tails extending nearly to the hocks, with no false hoofs but with glandular tufts of hairs on the cannon bones of the hind feet.

Skull without antorbital fossae and with very small, almost rudimentary lachrymal vacuities; premaxillae large and expanded 
forming a long suture with the nasals, and sometimes reaching even the lachrymal bones; a smooth oval vacuity between the premaxillae and maxillae on the side of the skull.

Horns long, broadly lyrate, half ringed and slightly compressed, female hornless.

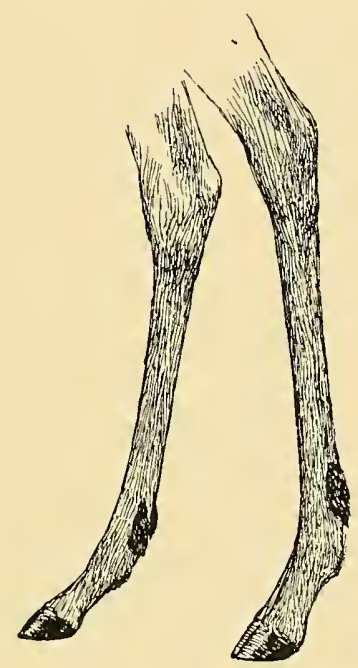

Fig. 54.-Hind feet of Aepyceros melampus to show the glandular tufts on the cannon bones.

This genus is found throughout eastern and southern Africa, from the Soudan and Angola southwards.

The two species generally recognised are separable as follows :-

A. Face the same colour as the body A. melampus, p. 203.

$B$. Face with marked brown patch running down the muzzle A. petersi, p. 207.

\section{Aepyceros melampus. The Pallah.}

Antilope melampus, Lichtenstein, Reise ii, p. 544, pl. iv, (1812); Smuts, Enum. Mamm. Cap. p. 74 (1832) ; A. Smith, S. Afr. Quart. Joum. ii, p. 209 (1834).

Aepyceros melampus, Sundevall K. Vet. Akad. Handl. 1845, p. 271 (1847) ; Kirk, Proc. Zool. Soc. 1864, p. 656 [Zambesi] ; Buckley, 
ibid. 1876, pp. 283, 291 ; 1877, p. 454 [distribution] ; Selous, ibid. 1881, p. 757 [distribution]; Barkley, ibid. 1894, p. 132 [Pungwe valley]; Lorenz, Ann. kk. Hofmus. Wien ix, notiz. p. 61 (1894); Rendall, Proc. Zool. Soc. 1895, p. 359 [eastern Transvaal] ; P. L. Sclater and 0 . Thomas, Bk. Antelopes, ii, p. 17, pl. xlviii. \& fig. 47 [head] (1897).

Aepyceros melampus holubi, Lorenz, Ann. kk. Hofmus. Wien ix, notiz. p. 62 (1894).

Literature.-Barrow (1806) p. 407, the earliest mention of the Pallah, met with near Kuruman by Messr's. Truter and Somerville; Lichtenstein (1812) ii, p. 334, translation of description; Burchell (1824) ii, p. 301, noticed near Kuruman and described under Lichtenstein's name; Harris (1838) pp. 141, 213, met with Pallah on the Marico and Limpopo rivers in North-west Transvaal; id. (1840), figured on plate xv, fig. 1; Livingstone (1857), p. 56, habits; Nicolls and Eglington (1892), p. 41, pl. i, fig. 3, description, distribution and habits; Bryden (1893), p. 509, distribution; Lyddeker (1893), p. 229, description with figure of head; Millais (1895), pp. 60-3, description and sketches of a Pallah shot in the Middelburg district of the Transvaal; Kirby (1896), p. 546, native names and habits in the Eastern Transvaal; Ward (1896), p. 143, horn measurements; Kirby (1899), p. 328, distribution in Mozambique; Kirby (1899a), p. 323, range and habits.

Vernacular Names.-Pallah of English; Roode or Rooibok of Dutch Colonists; Pala of Bechuanas (Lichtenstein and Burchell) and of Basutos (Kirby) ; Impala of Zulus, Swazis (Kirby) and of Matabele (Selous) ; Impaya of Shangaans (Rendall) ; Eepala of Makalakas; Inzezo of Masubias ; Kug-ar of Masaras (Selous).

Description.-General colour fulvous brown, darkest on the back and upper part of the sides, paler at the lower part of the sides and pure white below, hair thin, fine and lying flat and smooth; rhinarium a V-shaped bare space narrowly bordering the nostrils above only; no antorbital gland; a white patch above and in front of the eye, chin and throat also white; a dark patch in front of the eye and on the crown of the head often present, but by no means constant; ears moderate, fulvous posteriorly with white hairs inside and a black edging round the tip. Limbs slender, with no false hoofs, the true hoofs short, triangular and pointed, with a ring of white above them; attached to the lower ends of the canon bones of the hind legs is a brush of very dark brown hairs surrounding the opening of a peculiar gland containing a fatty secretion; a long narrow stripe of the same dark brown colour on either side of the tail on the buttocks; tail nearly reaching the hocks, rather slender with a median black or dark brown stripe 
commencing on the posterior part of the back and continued nearly to the tip, the sides being the same colour as the back, gradually paling to white at the end.

Female like the male, but without horns and with four mammae. Horns graceful, lyrate, convex forwards below, concave above, evenly spreading ringed to within a few inches of the tips.

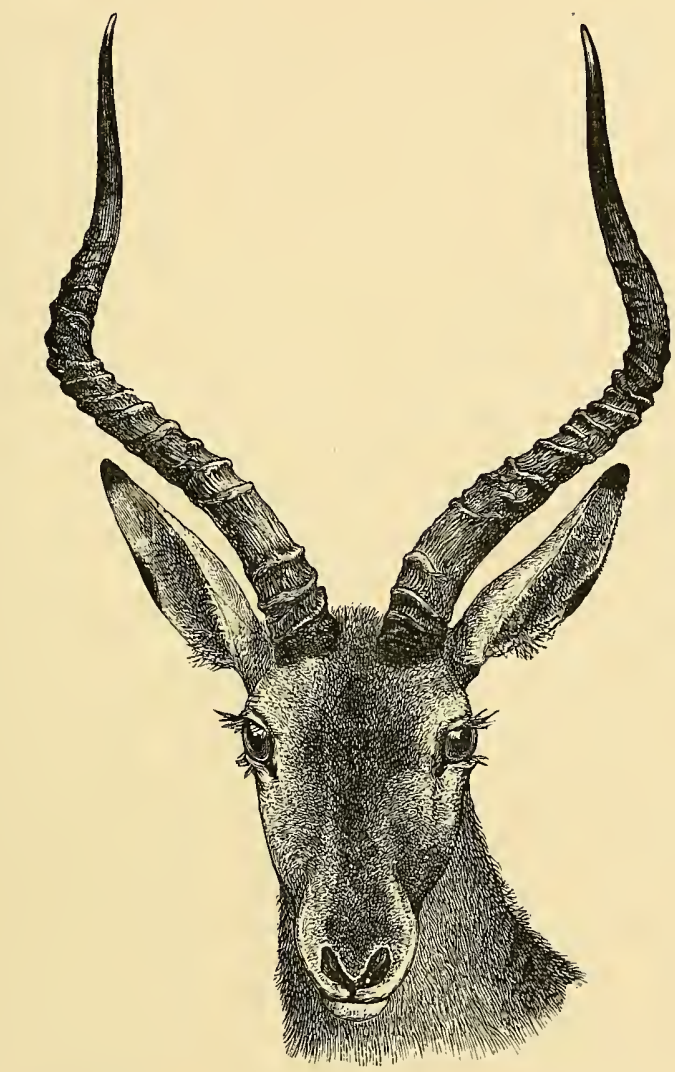

FIG. 55.-Head of a male Pallah (Aepyceros melampus).

(Book of Antelopes.)

Dimensions.-From a mounted male; head and body $4 \mathrm{ft.} 8$; tail $10 \cdot 50$, with terminal hairs 13 ; height at shoulders 34 inches; ear 5.50 ; from ear opening to nose tip $11 \cdot 50$.

A male skull measures 11.10 in total length, and 4.90 in breadth. 
The length of the horns varies a good deal in different parts of Africa, those from East Africa being the longest, measuring about 22 in. in a straight line; the largest yet recorded are a pair obtained by Lord Delamere in East Africa, which measured 30 along the curves, and 24 straight; the longest pair from South Africa, recorded by Ward, are a pair belonging to the Hon. Walter Rothschild, measuring $26 \frac{3}{8}$ along the curve, and 21 straight.

Distribution.-There can be little doubt that the pallah never existed in Cape Colony proper, and that Kuruman, in Bechuanaland, where it was first found, was its most southern limit; although now extinct in this locality, it is still found along the Limpopo and its affluents, in Zululand, the Eastern Transvaal, Portuguese East Africa and throughout Rhodesia, in suitable localities, and where not persecuted. North of the Zambesi it extends through Nyasaland, Mozambique and East Africa, both German and English, as far as the White Nile at Scherk-el Akaba, according to Heuglin.

The South African Museum possesses a fine mounted male from near Beira, and a young male with incipient horns from KomatiPoort in the eastern Transvaal.

History and Yariation.-The earliest published description of the pallah is to be found in the account of Truter and Somerville's expedition to Bechuanaland, published in Barrow's voyage to Cochin China in 1806. While the explorers were staying at Litakoo in 1801 , the Boer hunters attached to the party brought in several new animals, among them one of the present species, of which they gave a very good description under the native name. Subsequently Lichtenstein, when returning from a visit to the same place in 1805, obtained a male at Kosi fountain, a little further south, which he described under the Latin designation it has since borne.

Of recent years, Matschie, Thomas and Lorenz have separated the pallahs of German East Africa, Nyasaland and Barotseland respectively, from the type as distinct species or sub-species, but the differences appear to be trifling, and in addition to that, the coloration and dimensions of the animal appear to be by no means constant even in the same locality.

Habits.-The pallah is never found in the open country or very far from a river; its favourite resorts seem to be the forest-clad banks of streams where it finds plenty of shelter with occasional open spaces. It is a gregarious animal, consorting in herds of varying 
numbers, from small family parties to troops of as many as two hundred; such large congregations usually consist of females alone, or females with one or two old males, the young males keeping by themselves in small parties; when undisturbed they are easy to shoot since they almost always stop and look round after going a short distance; where persecuted, however, they naturally become far more wary; the alarm note is a whistle, and during the rutting season the males are very noisy, giving vent to a deep guttural bark. Their pace is moderate and not to be compared with that of a springbuck. Their powers of leaping are extraordinary, Kirby measured three successive bounds of 26,16 and $28 \mathrm{ft}$., making $70 \mathrm{ft}$. in all; they live entirely on grass, and drink three times a day. Nothing appears to be known about their breeding, but the young are born in November or December, and are said to be half grown in March.

Only two examples have apparently ever been brought to Europe, and these did not live very long.

\section{Aepyceros petersi. The Angolan Pallah}

Aepyceros petersi, Bocage, Proc. Zool. Soc. 1878, p. 741 ; P. L. Sclater, Proc. Zool. Soc. 1890, p. 460; P. L. Sclater and O. Thomas, Bl. Antelopes, iii, p. 25, fig. 48 [woodcut of head] (1897).

Description.-Similar so far as is yet known, to A. melampus in all respects, except that on the face there is a prominent brown patch running along the top of the muzzle.

Distribution.-The Angolan pallah was described by Professor Barboza de Bocage, from specimens procured by d'Anchieta at Capangombe and Humbe, in the Province of Mossamedes, north of the Cunene River in Angola. In 1889, Captain F. Cookson obtained a pallah belonging to this species, in Kaoko-land, south of the Cunene in German South-west Africa. This brings the animal within our limits.

The species is not represented in either the South African or British Museums. 


\section{Genus ANTIDORCAS.}

Antidorcas, Sundevall, K. Vet. Akad. Handl., 1845,

Antelopes of medium size, with the rhinarium much reduced, and no knee brushes; false hoofs present; hinder part of the back provided with a peculiar "fan" of long hairs erectile at the will of the animal.

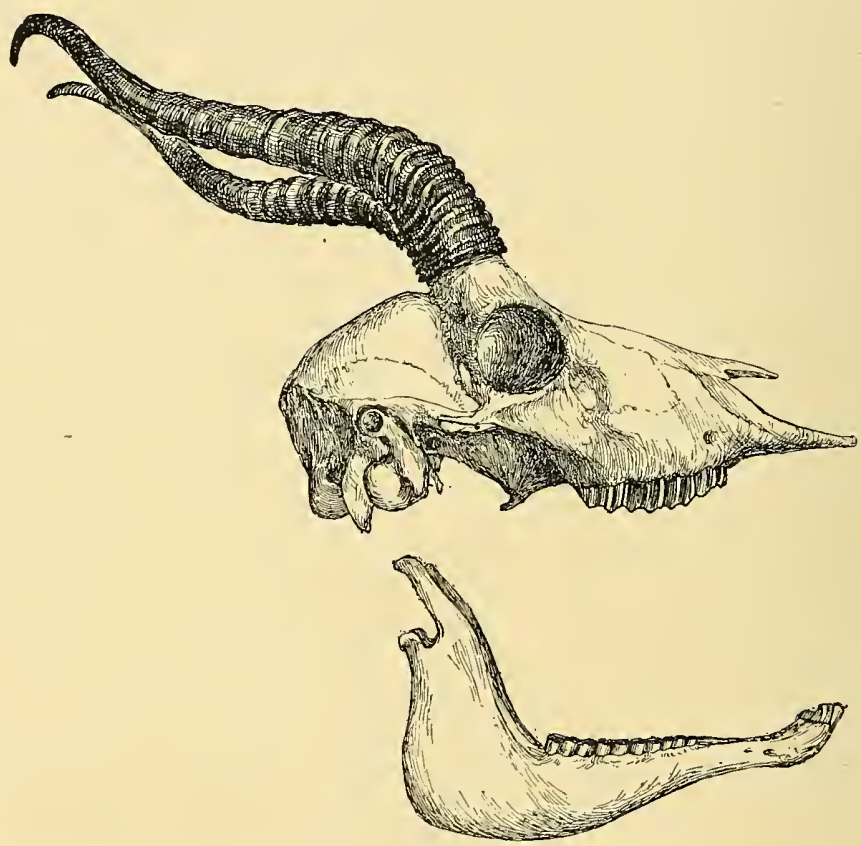

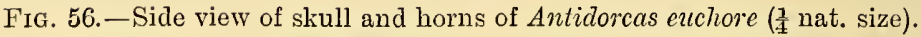

Skull small, with deep antorbital fossae, no lachrymal vacuities, and very large open posterior nares; the anterior upper premolar generally absent, the lower one always, so that the dentition is i. $\frac{0}{3}$, c. $\frac{0}{1}, \mathrm{pm} \cdot \frac{2 \text { or } 3}{2}, \mathrm{~m} \cdot \frac{3}{3}=28$ or 30 , in this differing from other genera of the family [except Saiga] all of which have three premolars above and below. 
Horns of males stout, strongly ringed, lyrate and doubly twisted, the lower portion convex inwards and forwards, the upper portion outwards and backwards, the points turned inwards; female also horned.

Only one recent species, the springbuck, formerly associated with the genus Gazella, but easily distinguished therefrom by its dentition and by its erectile "fan" is generally recognised. It is confined to Africa south of the Zambesi.

\section{Antidorcas euchore. The Springbuci.}

Antilope marsupialis, Zimmermann, Geogr. Gesch. ii, p. 427 (1780).

Antilope euchore, Zimmermann, Geogr. Gesch. iii, p. 269 (1783); Smuts, Enum. Mamm. Cap. p. 72 (1832); Lichtenstein, Darstellung Säugeth. pl, vii (1834).

Antilope saccata, Boddaert, Elench. Anim. p. 142 (1785).

Antilope saltans, Kerr, Linn. An. K. p. 312 (1792) [nec Pailas].

Antilope pygarga, Thunberg, Mem. Acad. Petersb. iii, p. 315 (1811).

Gazella euchore, A. Smith, S. Afr. Quart. Journ. ii, p. 191 (1834) Brookie, Proc. Zool. Soc. 1873, p. 550; Buckley, ibid. 1876, pp. 282, 291 ; Selous, ibid. 1881, p. 757.

Antidorcas euchore, Sundevall, K. Vet. Akad. Handl. 1845, p. 271 (1847) ; Layard, Cat. Mamm. S. Afr. Mus. p. 67 (1861); P. L. Sclater and O. Thomas, Bk. Antelopes, iii, p. 55, pl. li \& fig. 53 [horns] (1897).

Literature.-Masson (1776) p. 281, earliest mention of springbuck observed in the cold Bokkeveld; Allamand, Dutch ed. Buffon iv (1778), p. 142 , pl. 1x, gives a notice of the springbuck; Sparrman, K. Vet. Akad. Handl., Stockholm (1780) p. 275, description; Buffon (1782) suppl. vi, p. 176, translation of Allamand, and further description from Foster; Sparrman (1785) ii, p. 88, account of large herds met with on the plains of the Fish River, with plate; Thunberg (1795) ii, p. 24, as met with in the Bolkkeveld in 1773, described as Capra pygarga; Burchell (1824) ii, p. 109, account of habits on the karoo of Hanover; Harris (1840) figured on pl. iii, with a description of habits of "trek bokken "; Cumming (1855) i, pp. 62, 68, springbucks and their habits and migrations; Livingstone (1857) p. 56, on habits; Bryden (1889) pp. 226, 296, account of habits and shooting, with plate; Nicolls and Eglington (1892) p. 29, pl. vi, fig. 20, description, distribution and habits; Bryden (1893) pp. 376, 509, account of and distribution in Khama's country; Lydekker (1893) p. 238, description and habits; Millais (1895) pp. 14-17, habits and shooting, in the Beaufort West division of the Colony, with illustration of their attitudes and heads; Ward (1896) p. 163, horn measurements and dis. tribution; Scully, "Between Sun and Sand" (1898) in chapter viii, p. 99, 
a very detailed account of the "trek bokken" in Bushmanland will be found; Bryden (1899) p. 332, range and habits; Cronwright Schreiner in Cosmopolitan Mag., vol. xxvi, for Febr. (1899) p. 433, and Cape Times newspaper of March 17th (1899) account of the trekboks in 1896.

Vernacular Names.--Springbuck of the English, Springbok, or sometimes Pronk-bok of the Dutch colonists; Ibadi of the Amaxosa (Cloete); Tsepe, or Insaypee, of Bechuanas and Eetsaype of Makalakas (Selous).

Description.-General colour rufous fawn, slightly darker posteriorly, hair smooth and close-lying, and a little longer on the upper part of the neck of the male, forming an incipient mane; underside of neck, chest, belly and inside of limbs pure white, separated from the pale brown of the back by a very conspicuous dark brown lateral band; rhinarium a narrow line of bare skin bordering the nostrils above; all the face and chin pure white, save for a stripe of dark brown running from the base of the horns to the angle of the mouth, interrupted by the eye and the black bare space in front of it, in the centre of which is placed the opening of the antorbital gland; ears long and pointed, fawn brown posteriorly, dirty white within, with a few long white hairs along the edges; limbs fine and slender, with well-developed false hoofs, and narrow, pointed true ones. Along the middle of the hinder half of the back there is a line of long white hairs, which under ordinary circumstances are hidden by the overlapping brown hairs on either side; these white hairs, of which the longest attain a length of 5 or 6 inches, can be erected at the will of the animal and form the so-called fan; the white of the fan is continued down over the rump to the belly; tail rather short the proximal half stout and white, the distal half black and slender with a posteriorly directed fringe of long black hairs.

Fernale like the male, but with more slender horns and four mammae.

A very young male, with horns about an inch long, has a brown patch running along the top of the muzzle to the nose.

Out of eight skulls examined, 4 adult males, 2 young males, and 2 females, only one, an adult male, had the anterior premolar present on one side of the upper jaw; in two other males, however, there were small sockets showing that this tooth had been lost; the other five skulls were without traces even of the sockets; in the lower jaw the anterior premolars seem to be constantly absent.

Horns of the male as described above under this genus, those of the female more slender, less prominently ringed and more 
straight, with the tips, as in the males, directed inwards and a little backwards.

Dimensions.-From a mounted male; head and body $4 \mathrm{ft} .9$; tail 8.50, with terminal hairs, 13 ; height at shoulder $2 \mathrm{ft} .6$; length of ear 5.75; from ear to nose-tip $9 \cdot 0$; skull, length $9 \cdot 20$, breadth, $4 \cdot 20$.

A good pair of male horns in the South African Museum measures $14 \mathrm{in}$. along the curve, those of a female 10.25; the largest male pair recorded by Ward reach $19 \cdot 0$, the female 13 .

Distribution.-The springbuck is found at the present day, throughout the whole of the dryer districts of the Colony. from Namaqualand in the west, to Albert and Queenstown in the east and south as far as the Zwartberg and other ranges forming the southern boundary of the Karoo; it is not, and never has been, found in the Cape, Stellenbosch, and other south-western and southern districts; north of the Colony it extends throughout German South-west Africa, Bechuanaland, the Orange Free State, and the high veld of the Transvaal, and it is found along the desert and dry strip of coast north of the Cunene River certainly as far as Benguella. It does not appear to reach Mashonaland or Matabeleland proper.

Over a considerable part of its range, especially in the more settled parts of the Colony, the Free State, and the Transvaal, this antelope only now exists within the fences of the large farms, and can hardly be said to be any longer truly feral.

The South African Museum possesses a good mounted series of males, females, and young of various ages, from Culmstock in the Middelburg, and Langberg in the Kimberley divisions respectively.

History.-Perhaps the earliest mention of the springbuck was made by Masson, an English botanical collector, who travelled in South Africa in 1771-3. Subsequently Colonel Gordon shipped to Holland a dozen live examples, of which one only survived the voyage, and was described and figured by Allamand, in the Dutch edition of Buffon, while still living in the Menagerie of the Prince of Orange under the name of "La Gazelle a bourse sur le dos." Buffon, in his supplement published in 1782, reprinted Allamand's account and added additional information derived from the Fosters, who spent some time at the Cape, when with Captain Cook on his second voyage; it is on these two early descriptions that Zimmermann founded the Latin names Antilope marsupialis and A.euchore, 
of which the former has priority by three years; as, however, it has been altogether lost sight of, and the latter name is universally used it seems a pity to revert to the older name, though doubtless it will before long be revived by some ardent purist in nomenclature.

Among modern accounts that of Millais is illustrated with a life-like series of sketches made from the living animals on the veld, and that of Scully contains a vivid description of the great migrations which even now take place, though not on so vast a scale as formerly.

Habits.-Springbucks are always found on the open dry plains so characteristic of the central and western parts of the Colony; they seldom seek any shelter except during very cold weather or during the lambing season, when they sometimes resort to bush country; they are found in herds of varying size, and were often seen associating with guus, quaggas, ostriches and blesboks in the old days; now alas! in the Colony they are almost the only survivors of the "open country bucks." Their pace is very great exceeding that of a horse, though with a very good greyhound they can be run down; this, it is said, is never possible in the case of the blesbok. When startled, or even in pure playfulness, they take great leaps up into the air with the head down, body curved and legs held quite stiff and close together, at the same time displaying by the action of the skin muscles the singular white fan, already alluded to, which resembles, according to Harris, the spread tail of a peacock; the fan is never fully displayed except when leaps are taken. This whole display is termed by the Boers pronken, which is the same, I imagine, as the English to prink or make a brave show ; when disturbed or startled, after a few preliminary "pronks," they speed off up wind, and should they come to a road or track they clear it with a great bound of from 10 to $20 \mathrm{ft}$. without the least exertion. After a time, like most South African antelopes, they turn to gaze at the unexpected object of their fears, but usually so wary are they, that this is well beyond the reach of the bullet.

Their cry is described as a feeble bleat; their food consists of the various small bushes, chiefly belonging to the orders Compositce and Portulacaceae with which the karoo is clothed, but further north in Bechuanaland, where the country is covered with grass the springbok finds its nourishment on this; they are able to go without water for a considerable time, though if it should be accessible they drink every second day. 
The young are born in November, after a gestation period of about 171 days, and in the case quoted, which took place in the Zoological Gardens at Cologne, the single young was about 18in. in height at birth, and was generally of a yellowish grey colour with the side stripes but little marked.

The flesh is excellent eating, as I myself can affirm, and it is usually quite easily obtained during the season in Cape Town.

Far the most interesting fact, however, in the natural history of the springbuck is its periodical migrations, about the marvels of which much has been written, but about which little is known which will assist in forming an adequate theory on the subject. The Boers divide the springbucks into two classes, the "hou-bokken," which remain fairly constantly on one veld, and the "trek-bokken," which are migratory, and generally smaller and less well nourished. In the old days the numbers of animals taking part in a trek were extraordinary, and many stories are told illustrating this, such as their passing through the streets of small villages, their being so crushed together that they could be killed by a blow with a stick, and even that herds of sheep and their guardians who have met trek-bokken in a narrow pass or "poort" between the hills have been entirely overwhelmed and trampled to death. In 1896 there was a great trek, and on the borders of the Prieska and Hope Town divisions in the north of the Colony Mr. Cronwright Schreiner came across an undisturbed portion of the herd completely covering an immense amount of country, the numbers of which he and his companions estimated at 500,000 at the very lowest computation.

During the trek an enormous destruction takes place; all the neighbouring farmers and their people turn out and kill thousands; the skins are cured and the flesh made into " biltong," or sun-dried and cured meat for future consumption. In addition to their human foes the herds are followed by various wild carnivores, leopards, hunting dogs, hyaenas and jackals, and even strange antelopes are carried along with the flood; $\mathrm{Mr}$. Cronwright Schreiner, on the occasion above alluded to, heard of the appearance in the neighbourhood of three hartebeests and a kudu, animals which have been unknown in those parts for many years.

The cause of the migration is doubtless due to want of water and consequent absence of food.

There is no doubt that the swarms which migrate towards the more settled parts of the Colony come from the vast tracts of almost waterless country occupying the districts of Namaqualand, Ken- 
hardt and Calvinia in the north-west of the Colony known as "Bushmanland," and probably these again are re-inforced by additional numbers coming from the desert country to the north of the Orange River and the Kalahari.

Mr. Scully, who has resided in Namaqualand, states that "the trek is due to the instinct that impels the does to drop their young somewhere on the western fringe of the desert, which extends north and south for several hundred miles."

This fringe is the limit of the western rains. These fall between April and September when the desert is at its driest, and bring out the green herbage necessary for the new-born fawns. The fawning season over "the herd melts slowly away, and flows gradually eastwards until some night, distant flashes of lightning on the cloudless horizon indicate where perhaps hundreds of miles away the first thunderstorm of the season is labouring down from where its bolts were forged in the far north. Next morning not a buck will be visible, all will have vanished like ghosts, making for the distant track of the rain."

\section{Subfamily HIPPOTRAGINAE.}

Antelopes with long horns, curved, straight or spiral, of nearly equal development in both sexes; rhinarium very small, no antorbital glands, four mammae.

\section{Key of the South African Genera.}

A. Horns stout and scimitar-shaped, rising vertically upward from the head.

Hippotragus, p. 214.

$B$. Horns slender and straight, running back parallel to the back Oryx, p. 224.

\section{Genus HIPPOTRAGUS.}

Egoceros, Desmarest, Mammalogie, ii, p. 475 (1822)

Type. [nec Aegoceros, Pallas]

Aigoceros, H. Smith, Griff. Anim. Kingd. v, p. 324 (1827) [nec Pallas] H. leucophaeus. * Ozanna, Reichenbach, Vollst. Naturgesch. In- u. Auslandes, iii, p. 126 (1845) .................... H. niger.

Hippotragus, Sundevall, K. Vet. Akad. Handl. Stockholm, 1844, p. 196 (1846) H. leucophaeus.

* This name has been recently "rediscovered" and is adopted by some authors; its exact date however seems uncertain. 
Antelopes of large size and graceful and slender form with a comparatively small rhinarium occupying the V-shaped space above and between the nostrils; tail long and tufted; mammae four; accessory hoofs well developed.

Skull long with a very convex frontal region, the large horn cores rising almost vertically immediately above the orbits; lachrymal fissure almost obsolete; antorbital fossae absent, premaxillae not reaching the nasals.

Horns long, evenly divergent, vertical basally, thence strongly curved backwards like a scimitar, heavily ringed; females provided with horns similar to those of the male but of shorter and more slender build.

This genus is now confined to Africa south of the Sahara, though formerly it ranged over northern Africa, Southern Europe and Asia, as is evidenced by fossil remains from the Miocene and Pliocene beds of those countries.

Three quite distinct species can now be recognised, all of them inhabitants, or formerly inhabitants, of South Africa ; of one of these, the roan (H. equinus), four sub-species or geographical races, inhabiting different regions in Africa are distinguishable.

\section{Key of the South African Species.}

A. General colour pale grey or brown, horns only slightly exceeding the head in length.

a. Smaller about 45 in. at the shoulder; face without black markings ........................

b. Larger about $55 \mathrm{in}$. at the shoulder, face with strongly contrasted black markings

H. leucophacus, p. 215.

H. equinus, p. 217.

$B$. General colour black, horns much longer than the head

H. niger, p. 221.

\section{Hippotragus leucophaeus. The Blaauwbok.}

Antilope leucophaea, Pallas, Misc. Zool. p. 4 (1766); id. Spicil. Zool. i, p. 6 (1767), xii, p. 12 (1777); Schreber, Säugeth. pl. cclxxviii. (1784); Thunberg, Mem. Acad. Petersb. iii, p. 313 (1811).

Aigoceros leucophaea, Smuts, Enum. Mamm. Cap. p. 68 (1832);A. Smith, S. Afr. Quart. Journ. ii, p. 185 (1834).

Hippotragus leucophaeus, Sundevall, K. Vet. Aliad. Handl. 1844, p. 197 (1846); Kohl, Ann. k7. Hofmus. Wien i, p. 83 (1886); P. L. Sclater and O. Thomas B7. of Antelopes, iv, p. 5, pl. lxxvi. \& fig. 88 [horns] (1899). 
Literature.-Kolben (1731), ii, p. 114, described as the "Blew Goat"; Buffon (1782), Suppl. vi, pp. 168, 194, pl. xx, description copied from Allamand and note on the Fosters' account; Sparrman (1785), ii, p. 236, not met with but alluded to; le Vaillant $(1790)$, i, p. 130, account of shooting in Caledon; Thunberg 1795), ii, p. 113, note on habits and occurrence; Barrow (1801), i, p. 350, note on extinction ; Lichtenstein (1812), i, p. 166, note on its extinction; Bryden (1889), p. 290; Lydekker (1893), p. 245, remarks on extinction.

Vernacular Name.-Blaauw-bok of the colonists, not to be confounded with the Blaauw bokje or little blue buck (Cephalophus monticola).

Description.-Size much less than that of the two following species; general colour bluish grey; forehead brown, upper lip and a patch in front of the eye lighter than the general colour; there are none of the marked black and white contrasts so prominent in $H$. equinu; ears not so long or so pointed as in $H$. equinus, and without black tufts at their tips; mane on the nape of the neck short, inconspicuous and directed forwards; throat mane almost or quite absent; belly dull whitish, not contrasted with the sides; limbs with an inconspicuous darker line down the anterior faces; tail-tuft greyish but little darker than the general colour.

Skull unknown; none are preserved in any Museum so far as is known.

Horns like those of $H$. equinus, but smaller, and more slender and perhaps a little longer in proportion to the size of the animal. (Sclater and Thomas).

Dimensions.-Height at the withers of the male in Paris, 45 in., of female in Vienna, 40 in.; horns of the Paris specimen measure $21 \frac{1}{2}$ in. round the curve and have 28 rings; the pair in the British Museum are rather shorter, measuring 20 inches.

Distribution.-This animal, which is without the slightest doubt extinct, was formerly confined to the south-western corner of the Colony, now occupied by the districts of Caledon, Bredasdorp and Swellendam.

The last recorded specimen obtained is perhaps that mentioned by Lichtenstein as being in the Berlin Museum, though now it does not seem to be there; it was shot in 1799 .

At the present time only five complete mounted specimens are known to be in existence, they are to be found in the Museums of Paris, Leyden, Vienna, Stockholm and Upsala. 


\section{Hippotragus equinus. The Roan Antelope.}

Antilope equina, Desmarest, N. Dict. d'Hist. Nat. (1), xxiv, p. 4, tabl. p. 32 (1804).

Capra aethiopica, Schinz, Cuv. Thierr. i, p. 403 (1821).

Capra jubata, Goldfus, Schr. Säugeth. v, pl. cclxxxvii (1824).

Antilope (Aigoceros) equina, H. Smith, Griff. Anim. Kingd. v, p. 324

(1827) ; Smuts, Enum. Mamm. Cap. p. 69 (1832) ; A. Smith, S. Afr. Quart. Jour. ii, p. 185 (1834).

Antilope (Aigoceros) barbata, H. Smith, Griff. Anim. Kingd. v, p. 325 (1827).

Antilope truteri, Fischer, Syn. Mamm. p. 478 (1829).

Hippotragus equinus, Sundevall, K. Vet. Akad. Handl. Stockholm, 1844, p. 197 (1846) ; Buckley, Proc. Zool. Soc. 1876, p. 288 [distribution] ; Lorenz, Ann. kk. Hofmus. Wien ix, notiz. p. 62 (1894) [near Victoria Falls] ; Rendall, Proc. Zool. Soc. 1895, p. 362.

Aigoceros equina, A. Smith, Illustr. Zool. S. Afr. Mamm., pl. xxvi (1840).

Aegoceros leucophaeus, Gray, List Mamm. B. M. p. 158 (1843) [nec Pallas].

Hippotragus leucophaeus, Layard, Cat. Mamm. S. Afr. Mus. p. 75 (1861) ; Selous, Proc. Zool. Soc. 1881, p. 755 [nec Pallas].

Hippotragus equinus typicus, P. L. Sclater and O. Thomas, Bk. of Antelopes, iv, p. 13, pl. lxxvii \& fig. 90 [head] (1899).

Literature.-Daniell (1805), figured on pl. xxiv, as the Tackhaitse; Barrow (1806), p. 415, seen by Messrs. Truter aud Somerville near Kuruman; Jichtenstein (1812) ii, p. 283, occurrence in south Buchuanaland; Harris (1838), p. 184, first met with in the Rustenburg district of the Transvaal, p. 386, description with allusion to Daniell's Tackhaitse ; Harris (1840), figured on pl. xviii ; Cumming (1855), i, p. 157, met with this antelope in the Herbert division in 1843; Nicolls and Eglington (1892), p. 51, pl. ii, fig. 7, description, distribution and habits ; Bryden (1893), p. 503, past and present distribution; Lydekker (1893), p. 243, note on; Millais (1895), p. 126, habits in south-east Mashonaland with sketches; Kirby (1896) ए. 548, vernacular names, distribution and habits in the eastern Transvaal; Ward (1896), p. 181, horn measurements ; Selous (1899), p. 406, range and habits.

Vernacular Names.-Roan of English; Bastard Gemsbok or Bastard Eland, of the Dutch Colonists; Qualata of Northern Bechuanas, Taikaitsa of Southern Bechuanas; Ee-taka of Matabele; Ee-pala-pala-cheena of Makalakas; Impengo eetuba of Masubias (Selous); 'Mtagaisi of Swazis and Zulus, Klabakila of Basutos (Kirby).

Description.-General colour, a pale brown, becoming somewhat darker on the hinder part of the body; hair smooth, short and somewhat coarse, rather longer on the lower side of the neck, forming a throat mane; head parti-coloured, the nose, upper and 
lower lips, chin, stripe from the base of the horns past the front of the eye, and a rounded patch behind the eye white, rest of the face including the forehead and cheeks very dark brown, almost black; the white patch in front of the eyes ends in a considerable tuft of very conspicuous longer hairs; ears very long and pointed, grey round the base and posteriorly, pencilled with black at the tips; in life the ears droop considerably as figured. by Millais.* A dorsal

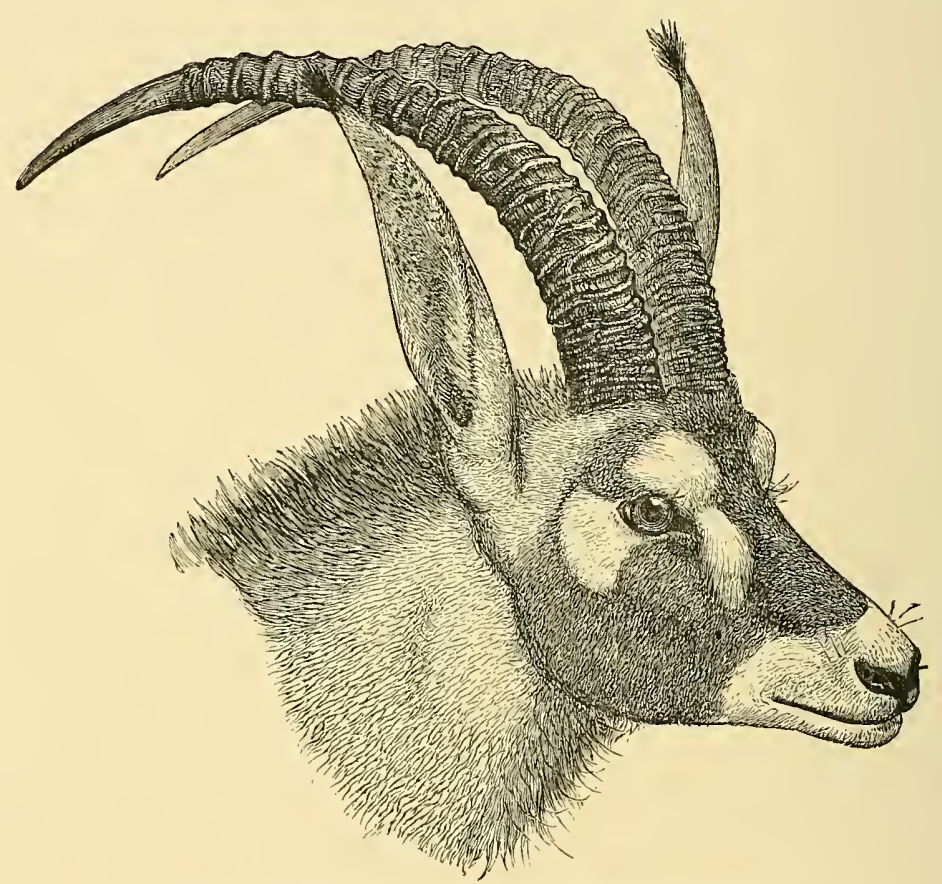

FIG. 57.-Head of the Roan (Hippotragus equinus).

(Book of Antelopes.)

mane of stiff upstanding hairs, the longest attaining a length of five inches, pale grey at the base becoming brown above and finally black, extends from behind the ears to the middle of the back; chest and inside of forelimbs chestnut-black, outside of limbs the same colour as the back; belly and inside of hind limbs white; tail reaching the hocks with a brush of long black hairs at its extremity.

* This point is not correctly shown in the figure. 
The female is slightly smaller than the male with the black of the face not so well marked and with four mammae; the young again have the face almost like the body colour.

According to Selous, there is considerable variation in the general colour of this antelope, some being of a strawberry roan, some dark brown, others almost white.

Horns stout and strong, cylindrical, transversely ridged, somewhat divergent, curved backwards through a quarter of a circle, rather short for the size of the animal; those of the female similar but slighter, shorter and less heavily ridged.

Dimensions.-Of a mounted male; head and body $8 \mathrm{ft} .1$; tail $18 \cdot 5$, with terminal hairs $24 \cdot 0$; height at shoulder $54 \cdot 0$, of a female 52.0 ; length of ear from notch $11 \cdot 0$, from ear-opening to nose-tip 19.0. A skull measures in extreme length $17 \cdot 0$, in breadth $7 \cdot 10$. Male horns average 29 to 30 along the curve, female 24; the record given by Ward is 33 , the bearer of which was a specimen obtained in northern Matabeleland.

Distribution and Geographical Yariation.-The roan is found all over Africa south of the Sahara except in the region of the great Congo forest; within this large range it exhibits as is natural, a certain amount of variation from what may be called the typical form originally described from South Africa; several of these geographical varieties have been considered as distinct species, but until a little more is known about them and direct comparisons can be carefully made, it seems best to regard them as sub-species only.

The following are the sub-species recognised in the "Book of Antelopes."

(1) H. equinus typicus, from South Africa.

(2) H. equinus rufopallidus, Neumann, Proc. Zool. Soc. 1898, p. 850, from German and British East Africa.

(3) H. equinus bakeri, Heuglin, Ant. \& Buff. N. O. Africa, p. 16, pl. ii, fig. 6 (1863), from the Upper Nile Valley.

(4) H. equinus gambianus, P. L. Sclater and O. Thomas, Bk. Antelopes iv, p. 13, pl. lxxviii (1899) from West Africa.

It is bowever, only with $H$. equinus typicus that we are here concerned; there is no evidence that this subspecies ever extended south of the Orange River, although Sir A. Smith does suggest that it once did so; north of that river it was formerly found in Griqualand West, and southern Bechuanaland, though hardly now surviving in those regions; it is still fairly abundant in German Sorth-west Africa, in Matabeleland and Mashonaland, in the south- 
eastern part of which it was recently obtained by Millais; it is also found, though now very rarely, in the eastern districts of the Transvaal, and has been recorded as far south as Swaziland. North of the Zambesi the roan is not uncommon in Barotse, Manica and Nyasaland, but whether these should be referred to the typical or "rufopallida" sub-species is uncertain.

The South African Museum possesses a good mounted pair shot by Selous in Mashonaland in 1883.

History.-The roan was first recognised as a new antelope under the Sechuana name of Takhaitse, by Messrs. Truter and Somerville, who in 1801, saw one in the neighbourhood of the Kuruman river in Bechuanaland; the animal was not obtained, but was sketched from the distance by the artist Daniell, who accompanied the expedition, and in consequence of his attaching a prominent beard to its chin in his subsequently published work, caused considerable confusion to later writers. In the meantime, Desmarest published a short description from a specimen of unknown locality in the Paris Museum, and it was not until some years later that the identity of Desmarest "equine antelope" with Daniell's "bearded antelope" was finally decided. Sir A. Smith, among writers of the middle of the century, and Millais among more recent authors, give excellent accounts of the habits of this animal.

Habits.-Roans frequent hilly and open country with scattered bush; they consort together in small troops, the number of which does not usually exceed 12 individuals, sometimes all females, sometimes with one male; the males too, are often solitary. Their pace is a gallop, and is not very fast; they can be ridden down with quite a moderate horse. When wounded, or even when only pressed, they will come to bay and charge very fiercely; an instance of this is given by Millais, where a horse was killed, and the rider had only a very narrow escape.

When wounded, the roan gives vent to loud sounds described by Buckley as a sort of hissing snort, by Millais as a loud bellow. Though this animal has been brought alive to Europe on a good many occasions, so far none from South Africa seem to have found their way, at any rate, to the London Zoological Gardens. 


\section{Hippotragus niger. The Sable Antelope.}

Aigoceros niger, Harris, Proc. Zool. Soc. 1838, p. 2 ; id. Trans. Zool. Soc. ii, p. 213, pl. xxxix (1841).

Hippotragus niger, Sundevall, K. Vet. Akad. Handl., Stockholm, 1844, p. 197 (1846); Layard, Cat. Mamm. S. Afr. Mus. p. 75 (1861); Buckley, Proc. Zool. Soc. 1876, p. 288; Selous, Proc. Zool. Soc. 1881, p. 756 ; Lorenz, Ann. kk. Hofmus. Wien ix, notiz, p. 62 (1894) [Limpopo R. and Victoria Falls]; Rendall, Proc. Zool. Soc. 1895, p. 362 [Eastern Transvaal] ; P. L. Sclater and O. Thomas, Bk. Antelopes, iv, p. 31, pls. lxxix, lxxx and fig. 91 [head] (1899).

Literature.-Harris (1838), pp. 256, 385, account of the discovery and shooting with description and measurements; Harris (1840), figured on pl. xxiii, with description; Cumming (1855), ii, p. 6, first met with in Bamangwato Country; Baldwin (1863), p. 186, met with the sable in the Marico district of the Transvaal in 1857, and figures it on a plate ; Nicolls and Eglington (1892), p. 50, pl. ii, fig. 5, description, distribution and lrabits; Selous (1893), p. 191, note on habits ; Bryden (1893), p. 503, note on distribution; Lydekker (1893), p. 243, description and figure of head; Millais (1895), p. 133, account of habits with sketches in south-east Mashonaland; Kirby (1896), p. 300, chapter on habits, p. 547, native names and distribution in the Eastern Transvaal; Ward (1896), p. 178, horn measurements; Bryden (1897), p. 263, chapter on habits and hunting; Kirby (1899), p. 327, distribution in Mozambique; Selous (1899a), p. 397, range and habits.

Vernacular Names.-Sable or sometimes Harrisbuck of the English. Zwart-wit-pens (i.e. black-white belly) of the Dutch spealing Colonists; Potoquane of the Sonth Bechuanas; Qualata inchu of Northern Bechuanas; Umtjiele of Matabele; Palapala of Makalakas (Selous); Inguarati and Maraballa of the Mashonas (Darling); Impalampala of Swazis and Zulus, Palahala of Basuto (Kirby).

Description.-General colour a very rich, deep brown; indeed the adult males may be considered black; hair of the neck not so long as that of the roan; face with a median dark brown stripe from the horn bases to the nose-tip, bordered on either side by a white stripe commencing above the eye, passing along a ridge in front of it where the hairs are somewhat longer, and running down to the upper lip; another brown stripe runs from below the eye forward to the nose on either side, rest of the face, upper and lower lips and chin white; rhinarium rather larger than that of the roan, crown of the head like the back; ears moderate, very acutely pointed, white inside, pale reddish brown posteriorly, tipped darker. A black dorsal mane runs from the level of the ears to the middle of the back; belly, inside of upper part of hind legs and rump pure 
white, sharply contrasted with the colour of the back; tail like that of the roan, very dark brown, ending in a long black tuft.

Female with more slender horns, and less dark in general colour; the occipital region especially being of a reddish-brown and contrasting with the rest of the body; four mammae.

Skull closely resembling that of the roan, but with longer premaxillae reaching the nasals, and with a longer palatal notch, reaching well beyond the level of the posterior molar.

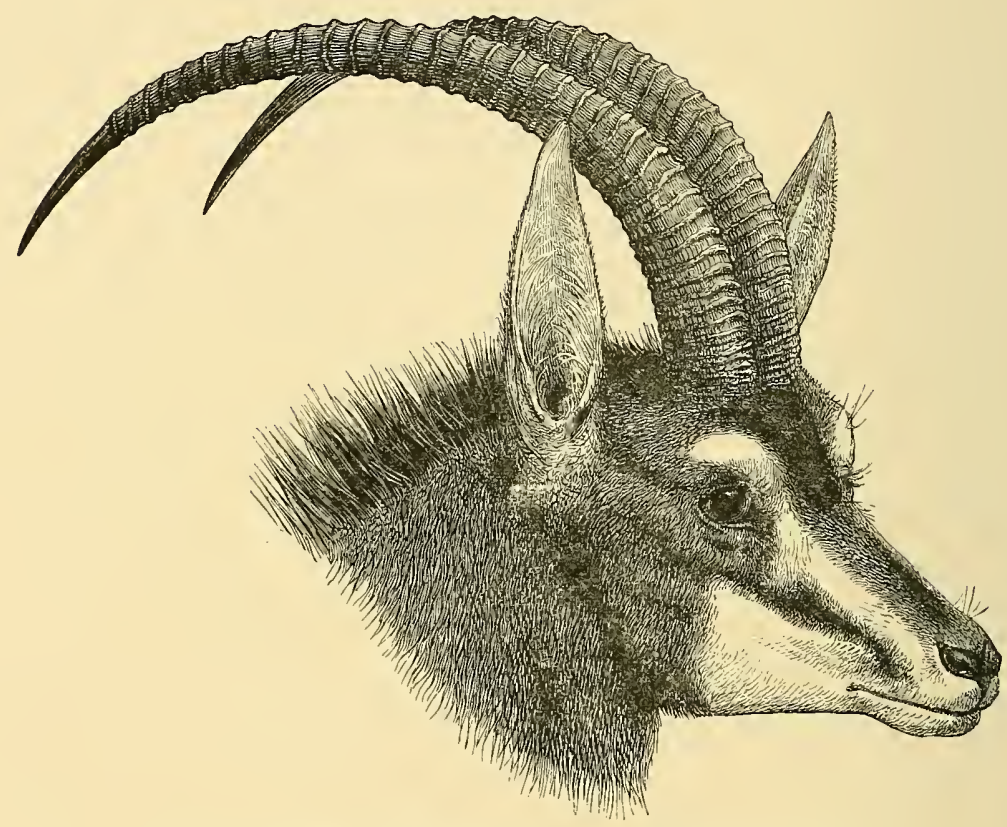

FIG. 58.-Head of the Sable Antelope (Hippotragus niger)

(Book of Antelopes.)

Horns much longer than those of the roan, somewhat laterally compressed, heavily ringed and backwardly curved; those of the female similar, but shorter and more slender.

Dimensions.-Of a male, adult but not very old; head and body 7 ft. 3 ; tail 15.0, with terminal hairs 24.0 ; height at shoulders 49.50 (a large male often stands 54 to 56 ); ear from notch 8.0 ; from ear opening to nose-tip $17 \cdot 50$; a skull measures in length 16.50 ; in breadth 6.25. Good male horns attain a length of from 
38 to 42 inches along the fiont curve, Ward's records are 46 from a specimen obtained by Mr. W. R. Bowker, in the Eastern Transvaal, and $45 \frac{1}{4}$ from a specimen shot by Mr. J. Millais in south-east Mashonaland, and Mr. Selous states that he once measured a pair, one of which was 48 , the other $47 \frac{1}{4}$; female horns are considerably smaller, the largest obtained by Mr. Selous measured $39 \frac{1}{8}$.

Distribution.-The sable antelope was first obtained from the Magaliesberg or Cashan mountains, in the western part of the Transvaal, where, however, it appears to be now exterminated; it is still found sparingly in south-western Rhodesia, but it is in the eastern Transvaal, Mashonaland, and the adjoining Portuguese territory, that it occurs most abundantly. North of the Zambesi it extends throughout Mozambique and Nyasaland (whence there is a skin in the South African Museum); it is rare in German East Africa, north of which there seems no positive evidence of its occurrence; on the western side of Africa it is found near the Victoria Falls, and from there extends through Barotseland to southern Angola, where it was obtained by the botanist Welwitsch.

In the South African Museum there is, in addition to the skin above mentioned, a good mounted pair obtained by Mr. Selous in 1882, in Mashonaland.

History.-To the celebrated Anglo-Indian Officer and Sportsman, Colonel W. Cornwallis Harris, belongs the sole credit of the discovery of this noble antelope. The event took place in 1836 on the northern slopes of the Cashan, or as they are now called the Magaliesberg range of mountains, which form the water-parting between the Vaal and the Limpopo rivers and which are now in the Rustenburg district of the Transvaal; full accounts of the matter will be found in both Harris' works above quoted, and also in his paper in the Zoological Society's Proceedings; his specimen, a male and the type of the species, is now in the British Museum. Of modern sportsmen, Kirby and Millais give very detailed accounts of the sable, the latter's work being embellished with sketches made in the field.

Habits.-Sables seem to prefer the open, rolling, thinly-wooded high veld, but are also found in more thickly bushed low country to which they have probably been driven by persecution. They are gregarious in herds of from eight to forty individuals consisting, as a rule, of only one adult male, a few young males, and the rest females and young; other old males are solitary or sometimes keep with three or four of their fellows. 
In speed they vary a good deal but are hardly equal to wildebeest or sassaby ; it seems generally agreed that with a good horse they can be ridden down and, apart from pace, they are frequently circumvented owing to their insatiable curiosity. When running they arch their heads so as to throw up and show off their horns and swing their tails from side to side. The only noise to which they give vent is a loud snort.

The sable is a very dangerous animal to approach; when at bay or wounded, it lies down and strikes out sideways with its horns; Mr. Selous relates how he had four of his best dogs killed outright and four others very badly wounded in this way, though on this occasion the animal was standing at bay in a stream; instances even have been told of lions being killed in this manner.

The calves, of which as a rule only one is produced at a birth, are born mostly in November and December in Mashonaland after a period of gestation (as observed in Europe) of 272 to 281 days.

Sables do very well in captivity; Mr. Rhodes has a number of them in his grounds near Cape Town, where they breed regularly and form a most attractive group; they are very tame and friendly and will come up to the edge of the paddock to lick the visitor's hand. Many, too, have been taken to Europe and are to be seen in the various Zoological Gardens there.

\section{Genus ORYX.}

Oryx, Blainville, Bull. Soc. Philom. p. 75 (1816) $\quad$ …..... O. gazella.

Antelopes of large size with short forwardly directed dorsal manes, no antorbital glands, long tufted tails, false hoofs and four mammae.

The skull differs from that of Hippotragus by being without the concave form of the forehead caused by the uprising of the horn cores, and is further distinguished by a considerable vacuity between the nasal, frontal, lachrymal and premaxillary bones.

Horns present in both sexes, placed quite behind the orbits and directed backwards almost parallel to the back of the animal, ringed at their bases.

Of this genus there are five species usually recognised, one of which is South African and is described below, the others, which are found in other parts of Africa and the deserts of south-eastern Asia, are as follows:- 
(1) O. beisa (Rüppell), the beisa from Somaliland and Northern Africa.

(2) O. leucoryx (Pallas), the leucoryx from North Africa.

(3) O. callotis Thos., the pencil-eared beisa from British and German East Africa.

(4) O. beatrix Gray, the beatrix from Arabia and Syria.

\section{Oryx gazella. The GersboK.}

Capra gazella, Linnaeus, Syst. Nat. 12th ed. i. p. 96 (1766) [in part].

Antilope bezoartica, Pallas, Miscell. Zool. p. 8 (1766) [nec Linn.].

Antilope recticornis, Erxleben, Syst. Reg. Anim. p. 272 (1777).

Antilope oryx, Pallas, Spic. Zool. Geogr. xii. p. 16 (1777); Thunberg, Mem. Acad. Petersb. iii, p. 313 (1811).

Antilope (Oryx) oryx, Blainville, Bull. Soc. Plilom. p. 75 (1816); Smuts, Enum. Mamm. Cap. p. 71 (1832); Matschie, S. B. nat. Fr. Berlin, p. 102 (1893).

Oryx capensis, A. Smith, S. Afr. Quart. Journ. ii, p. 187 (1834); Ogilby, Proc. Zool. Soc. 1836, p. 139; Buckley, Proc. Zool. Soc. 1876, p. $289 ; 1877$, p. 455 [distribution].

Oryx gazella, Gray, List Mamm. B. M. p. 156 (1843); id. Knowsley Menagerie, p. 17, pl. xxiv, fig. 1, [juv] (1850); Layard, Cat. Mamm. S. Afr. Mus. p. 76 (1861); Selous, Proc. Zool. Soc. 1881, p. 755 ; P. L. Sclater and O. Thomas, Bk. Antelopes, iv, p. 57, pl. lxxxiii (1899).

Literature.-Buffon (1782), Suppl. vi, p. 155, pl. xvii, good description and figure from Allamand; Sparrman (1785), ii, p. 234, account of synonomy, habits and structure; Paterson (1790), p. 53, met with Gemsbok in Clanwilliam; Barrow (1801), p. 55, met with Gemsbok in Willowmore; Lichtenstein (1812), ii, p. 23, found Gemsbok plentiful in Aberdeen in 1804; Burchell (1822) ii. p. 23, notes the Gemsbok in the Hopetown district and describes it as $A$. ory $x$; Steedman (1835), ii, pp. 15, 54, 56, and 119, devotes considerable attention to this animal and figures it; Harris (1838), pp. 84, 309 , met with Gemsbok on the Molopo and Modder Rivers in Bechuanaland and the Orange Free State; Harris (1840), figured on pl. ix; Cumming (1855), i, p. 97, gives a good account of the habits and occurrence of this animal in the Philipstown and Hopetown divisions in 1843-4 and on $p$ 144 notes its occurrence in Herbert; Andersson (1856), p. 279, describes the animal and its habits and gives a plate; Livingstone (1857), p. 56, notes that it can subsist without water ; Bryden (1889), pp. 292, 386, with plate, account of distribution and approaching extinction within the Colonial boundaries; Nicolls and Eglington (1892), p. 49, pl. v, fig. 17, description, distribution and habits; Bryden (1893), pp. 306, 504, occurrence in norther'n Bechuanaland ; Lydekker (1893), p. 246, description with figure; Oswell in Badminton Big Game Shooting (1894), i, p. 130, reminiscences of the Gemsbok, its 
habits and shooting in the fifties; Ward (1896), p. 184, horn measurements ; Bryden (1899), p. 382, range and habits.

Vernacular Names.-Gemsbok of the Colonists; Icowa of Ainaxosa (Stanford); Kokama or Kukama of Bechuanas and Makalakas; Ko of Masaras (Selous).

Description.-General colour a fawn grey, fur close lying and coarse; rhinarium not much developed, V-shaped, not extending to the lower side of the nostrils; head and face parti-coloured, rich brown and white, the latter colour being distributed over the front

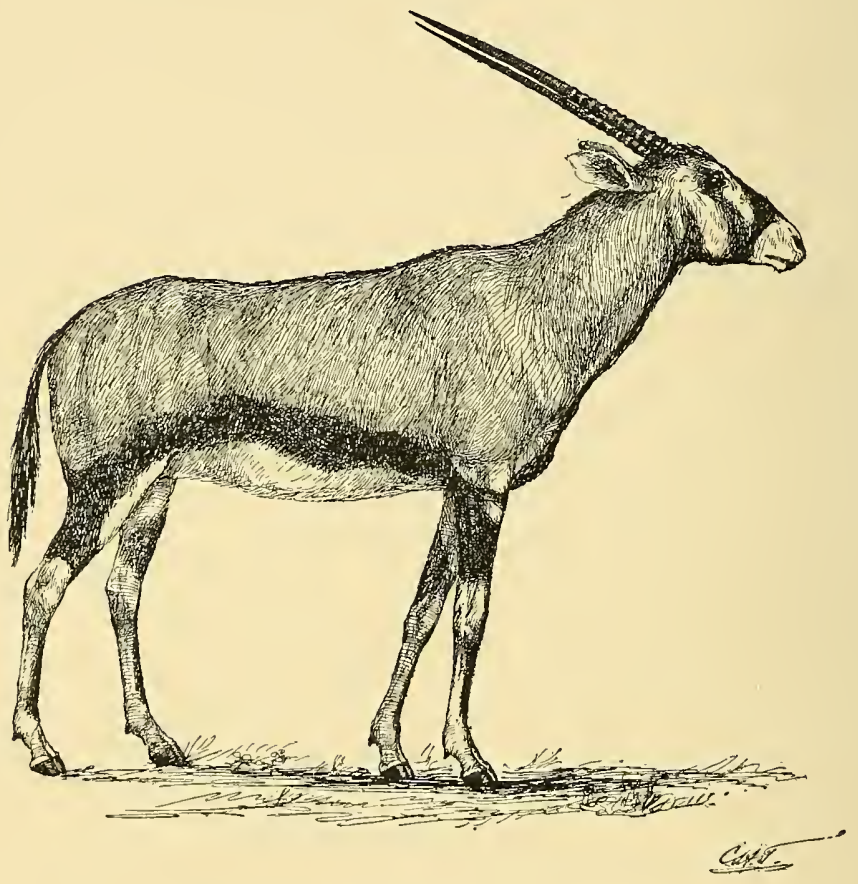

FIG. 59.-The Gemsbok (Oryx gazella).

of the muzzle, the upper and lower jaws and chin, in two longitudinal streaks running from the horn bases in front of the eye to the middle of the cheeks and connected across the forehead so as to form an $H$, and in two streaks running from the base of the horns behind the eye to the posterior part of the lower jaw ; the rest of the face, including a patch on the nose, two streaks down the cheeks, the occiput and the hinder part of the chin dark brown or 
black; ears moderate, rather broad, getting slightly darker at the tips; a short dorsal mane forwardly directed runs along the neck from the withers and is dark brown in colour, behind the mane the line of colour is continued on, expanding on the haunches into a diamond-shaped patch; from the chin a brown line runs along the lower side of the neck, where it gives rise to a long tuft of black hairs, to the chest where it expands and forks, being continued on either side along the flanks separating the grey of the sides from the white of the belly; limbs white with complete dark brown rings on the upper part of leg and patches in front of the shin; hoofs flattened and triangular. Tail long, reaching well below the hocks, basal portion short-haired and dark brown, terminal portion with a long black tuft.

Female without throat tuft, with the diamond patch on the haunches less marked, and with slender and generally longer horns and four mammae.

A young one, with horns about an inch in length, the tips of which are bent over and soft, is a very pale reddish brown all over, except a streak below the eye and the tail tuft, which are black.

Horns springing from behind the orbits, long, straight, backwardly directed, parallel to the line of the face, ringed for about half their length, and slightly divergent only.

Dimensions.-From a mounted female; head and body $6 \mathrm{ft} .3 .5$; tail 16 in., with terminal tuft $27 \cdot 0$; height at shoulders $45 \cdot 0$ (Gordon Cumming gives 46.0; Nicolls and Eglington 48.0); ear from notch 7.0 ; from ear opening to nose-tip 15.5 ; a skull measures 16.0 in length by 6.25 in breadth.

A good average length of the horns of either male or female is 36.0 ; Selous gives 42 and 46.5 as the records met with by him for male and female respectively. Ward heads his list with a pair measuring $47 \cdot 50$, belonging to Mr. J. S. Jameson, the sex of which is not specified.

Distribution.-The gemsbok is essentially a desert animal, and is only found in the drier parts of South Africa; formerly it was widespread all over the karoo and central plains of the Colony. Paterson met with it in Clanwilliam on the Dorn River, in 1778, and Gordon Cumming much later, in 1843-4, shot many in what are now the Philipstown and Hopetown divisions of the Colony. At the present time there are a considerable number still existing south of the Orange River in Bushmanland, a desert tract between the divisions of Namaqualand, Kenhardt, Calvinia and Prieska; 
north of the river the gemsbok exists in considerable numbers in German South-west Africa and the bordering Kalahari, extending to the southern and western confines of Matabeleland and to Ngamiland. Beyond our limits the gemsbok is found along the narrow strip of desert country bordering the sea in the south of Angola as far as Mossamedes, as has been reported to me by residents there.

History.-Buffon in the 6th volume of his supplement gives a good description accompanied by a recognisable figure of the gemsbok drawn up from material furnished by the Fosters, who were at the Cape during Cook's second voyage; to this is added further particulars derived from Allamand, who in turn obtained his information from Colonel Gordon in South Africa and a Dr. Klockner in Holland.

It is very doubtful whether Linnaeus' and Pallas' first names quoted in the synonomy, really belong to the present animal; they are both founded on Ray's "Indian gazelle, with long straight black horns," which possibly may have been the northern African form (O. beisa), but it will be best to leave the names as they now stand until further researches can be made into this vexed point.

Habits.-The gemsbok and the springbok are the most typical desert-loving types among South African antelopes; they are always found in a quite open country, or in one with only very stunted bush; here the former associates in pairs, or in small family parties, though Gordon Cumming states that he saw as many as 25 together on one occasion. Much discrepancy exists in the accounts of the speed of this animal; the older authors such as Steedman, Gordon Cumming and Andersson state that it is almost impossible to ride one down unless extremely well mounted; Selous and Nicolls and Eglington, on the other hand, assert that it is not nearly so fast as it is reported to be. Possibly, as Gordon Cumming suggests, the season and the individual condition of the animal may have a good deal to do with the matter.

The gemsbok is generally stated never to drink, but this appears to be an exaggeration, as Andersson has seen many obtained by poisoning the pools of water where they do drink; but there can be no doubt that they can exist independently of water for a long time, and that they are able to obtain the necessary liquid from the wild water-melons, (Citrullus sp., nat. order Cucurbitaccae) and from the watery bulbs (Pachypodium sp., nat. order Apocynaceac and 
Brachystelma nat, order Asclepiadaceae) which they are able to dig up with their hoofs, and which are widely distributed over the desert.

The gemsbok is reported to be a very dangerous animal when brought to bay. Steedman tells a story of a horse being killed by the charge of a wounded animal, and even lions are said to have been found dead on the veld transfixed by its sharp horns; dogs, too, are frequent sufferers, the animal lying down and sweeping with its horns in all directions and dealing great destruction among them.

This animal has been often identified with the unicorn of fable and mythology, owing probably to the fact that when looked at from the side it appears to possess only one horn. Whatever may be the truth regarding this, the gemsbok has been adopted by the Cape Colony as the sinister supporter of its armorial bearings, the dexter one being the black wildebeest. (See frontispiece).

\section{Subfamily TRAGELAPHINAE.}

Antelopes of large or median size, with a large rhinarium, approximated nostrils, and small antorbital glands; horns present usually only in the males, not ringed or knotted but spirally twisted or straight; body often decorated with white spots or stripes.

\section{Key of the South African Genera.}

A. Horns only in the males, spirally twisted.

a. Smaller, anterior ridge of homs not well marked ........................................ Tragelaphus, p. 225 .

b. Larger, anterior ridge of horns very strong ...... Strepsiceros, p. 240.

$B$. Horns in both sexes, straight with a spiral ridge encircling them

Taurotragus, p. 246.

\section{Genus TRAGELĀPHS.}

Tragelaphus, Blainville, Bull. Soc. Philom. p. 75

Type. (1816).......................................... T.

Antelopes of moderate size with a large moist rhinarium, occupying all the space between the nostrils, and hardly extending to below them; with antorbital gland present but small, and with a very small aperture, and with moderate very bushy tails. 
Horns in the males only, subangular, conical, and tapering, obscurely ridged and spirally twisted from the bases outwards and upwards.

Skull with small supra-orbital pits and lachrymal fissures; molars brachyodont, with small inner accessory columns in the upper jaw.

The recent members of this genus are confined to the Ethiopian Region; of the six species generally recognised three do not enter our limits, these are,-

T. euryceros (Ogilby), the West African Bongo.

T. gratus, Scl., the West African Harnessed Antelope.

T. spekei, Scl., Speke's Antelope from Central Africa.

A. Hoofs normal.

\section{Key of the South African Species.}

a. Smaller, about $34 \cdot 0$ at shoulder, male with

long hair around the neck and along the

lower flanks.

T. scriptus, p. 230.

$a^{1}$. No transverse or longitudinal white lines in adult or young; male dark brown ...

$b^{1}$. Two or three obscure transverse stripes on the posterior part of the body; male brown

T. s. sylvaticus, p. 230.

$c^{1}$. Numerous white transverse and longitudinal stripes, male bright rufous

T. s. roualeyni, p. 231.

T. s. typicus, p 231.

b. Larger, about 38.0 at shoulder; male with long shaggy hair on the neck and along the flanks and belly

$B$. Hoofs greatly elongated and forming with the false hoofs a kind of swamp shoe; male and female almost uniform, pale mouse brown ... T. angasi, p. 234.

\section{Tragelaphus scriptus.}

Owing to the great variability of this species, it is necessary to divide it into several sub-species or geographical races, of which four are distinguished by Mr. O. Thomas, in his paper quoted below. Three of these are South African, the fourth, T. scriptus decula, is found only in Abyssinia and north-eastern Africa, and need not here concern us.

(a) T. scriptus sylyaticus. The CoLony Bushbuck.

Antilope sylvatica, Sparman, K. Vet. Akad. Handl. Stock.holm, p. 197 (1780). 
Antilope (Tragelaphus) sylvatica, Smuts, Enum. Mamm. Cap. p. 87 (1832) ; A. Smith, S. Afr. Quart. Journ. ii, p. 218 (1834).

Tragelaphus sylvaticus, Grill, K. Vet. Akad. Handl. Stockholm, ii, 2, p. 19 (1858) [Knysna]; Layard, Cat. Mamm. S. Afr. Mus. p. 78 (1861); Selous, Proc. Zool. Soc. 1881, p. 752 ; Rendall, Proc. Zool. Soc. 1895, p. 359 [Eastern Transvaal].

Tragelaphus scriptus sylvaticus, Thomas, Proc. Zool. Soc. 1891, p. 389.

(b) T. scriptus roualeyni. Gordon Cumming's Busf Buck.

Antelopus roualeynei, Gordon Cumming, Hunter's Life, 1st ed. ii, p. 165 (1850) ; Selous, Proc. Zool. Soc. 1881, p. 753.

Tragelaphus scriptus roualeyni, Thomas, Proc. Zool. Soc. 1891, p. 389 ; Lorenz, Ann. kk. Hofmus. Wien xi, p. 6 (1896).

\section{(c) T. scriptus typicus. The Harnessed Antelope.}

Antilope scripta, Pallas, Miscell. Zool. p. 8 (1766).

Tragelaphus scriptus typicus, Thomas, Proc. Zool. Soc. 1891, p. 388.

Literature.-Buffon (1782), Suppl. vi, p. 192, description and figure from Allamand ; Sparrman (1785), i, p. 288, detailed account of the boschbok, with illustration on pl. vi, of vol. ii ; Moodie (1835), ii, p. 139, note on their abundance in the Alexandria division; Harris (1840), figured on pl. xxvi; Drummond (1875), p. 379, occurrence and shooting in Zululand; Selous (1881), p. 285, the Zambesi and Chobe form figured and described; Nicolls and Eglington (1892), p. 37, 38, pl. v, fig. 16, description, distribution and habits; Lydekker (1893), p. 252, description and habits; Millais (1895) p. 195, on the races found in South-east Mashonaland, figured on p. 69 ; Kirby (1896), pp. 117, 548, native names, habits, and geographical races of the Eastern Transvaal ; Ward (1896), p. 194, horn measurements ; Kirby (1899), p. 327, note on the bushbucks of Mozambique; Kirby (1899a), p. 484, variation, range and habits.

Vernacular Names.-Boschbok of Dutch, Bushbuck of English Colonists; Imbabala of Amaxosa (Stanford); Zulus (Stanford); Swazis (Kirby); and Matabele (Selous); when referring definitely to a particular individual bushbuck, the Zulus and Amaxosa make use of the term Unkonka for the male, and Imbabakazi for the female, but Imbabala is not applied to the doe alone as is so often stated; Serolobutuku of Bechuanas (Selous); Shomo of Shangaans (Rendall).

Description.-Of a male bushbuck ( $T$. s. sylvaticus); general colour above and below a dark sepia brown, the hair rather coarse and smooth lying, the forehead and round the eyes somewhat more rufous; upper and lower lip and chin, a spot below the eye, sometimes another one in front of the eye, transverse patches on the upper and lower part of the neck, a patch on the inside of the legs above the knee, and on the inside of the lower part of the legs, a 
pair of round spots on the metacarpals and metatarsals, and finally a few scattered spots on the flanks all white; ears broad and rounded, white inside with a row of long white hairs along the inner margins. Lower neck nearly always worn smooth and hairless, especially at the sides, possibly owing to the rubbing of the horns which are generally held back along the line of the neck; a line of longer hairs forming a kind of erectile mane runs from in front of the shoulders to the base of the tail, these hairs are partially white and form an ill-defined white dorsal line; limbs slender, with small false hoofs and short compact true hoofs; tail reaching about halfway to the hocks, very bushy, with long hairs throughout, brown above and white below. Female without horns, markedly smaller than the male, and with the sepia brown replaced by a lighter and more rufous brown, the dorsal mane being but little developed, and with four mammae. Young one like the female, but somewhat more spotted.

Horns straight, black, spirally twisted as a rule hardly forming one turn, the anterior longitudinal ridge more or less obsolete, the posterior one marked, the bases roughened transversely, the tips smooth.

Dimensions.-From a mounted male; head and body $4 \mathrm{ft} .10$; tail $9 \cdot 0$, with terminal hairs 10.5 ; height at shoulder 34.0 ; from ear opening to nose-tip 10.5 ; ear from notch 5.75 ; a female measures $3 \mathrm{ft} .9 .5$ in extreme length, and 25.0 in height at the shoulder.

A skull measures 9.18 in length; 3.75 in breadth; and 2.45 along the upper cheek teeth.

Horns of an adult average 12 to 14 inches; the best pair recorded by Selous from the Colony, measured $16 \frac{1}{2}$ in.; Ward gives the record as $17 \frac{7}{8}$ in., from near Zanzibar, while the largest South African head is one in the possession of Mr. A. Bowker, measuring $16 \frac{1}{2}$.

Distribution of the Sub-species or Geographical Races.-As already mentioned, all the African bushbucks are best considered as a single species, with various geographical races or variations, of which the following are the most marked.

(1) T. scriptus sylvaticus. - The Colony bushbuck; dark brown especially in the male, with no transverse stripes in either adult or young, and with but a few spots on the haunches.

(2) T. scriptus roualeyni.-The Limpopo bushbuck; dark brown, especially in the males, with two or three obscure transverse stripes 
on the posterior part of the body, and the haunches somewhat more spotted than in the Colony bushbuck.

(3) T. scriptus typicus. - The West and Central African bushbuck; bright rufous in the male, marked brilliantly with numerous white spots, and with longitudinal and transverse stripes; chest with a blackish mane.

(4) T. scriptus decula. - The Abyssinian bushbuck; rather smaller and stouter than the other forms; colour yellowish rather than rufous; transverse bands obsolete, but a longitudinal one generally present; only the haunch spotted, dorsal line dark in both sexes.

It must be remembered, however, that these are merely descriptions of the most salient types, and that a number of exceptions and intermediate forms are bound to occur.

Distribution.-The Colony bushbuck is found in the Colony only along the south coast and in the eastern districts, extending as far west as Danger Point in the Caledon division, while eastwards where the country becomes more wooded, it spreads further inland; it is one of the commonest antelopes of Natal and Zululand. Further north, in the Limpopo valley, the Limpopo variety commences, which extends throughout Eastern Rhodesia, Nyasaland, and East Africa to Mombasa. In the Upper Zambesi valley, again, the typical West African form has been procured by Selous which extends upwards through French Congo and Uganda to West Africa.

The South African Museum possesses a pair of mounted specimens from the Addo bush near Port Elizabeth, belonging to the typical colonial variety.

History and Habits.--Sparrman was the earliest writer to give an account of the bushbuck from observations made during his journey along the south coast of the Colony to Algoa Bay in 1775, and about the same time Allamand, in Holland, published a figure and a description drawn up from material received from Colonel Gordon at the Cape; this was reprinted in Buffon's supplement. Later writers and sportsmen, such as Drummond and Kirby, have further enlarged upon the natural history and shooting of this now comparatively well-known antelope from whose accounts, and from that communicated to me by Mr. T. G. Griffiths of Port Elizabeth, the following notes are gathered together.

Habits.-The bushbuck is found only in thick bush and forest, whence it seldom emerges, except in very early morning or late evening, in order to feed along the edges or in the open glades. It 
is perhaps the most nocturnal of all South African bucks, and it is also very limited in its individual range, seldom wandering far from one particular tract of bush, in which it may nearly always be found. It runs, as a rule, in couples, with sometimes a kid as well, never in large parties. During December, January, and February, when the ewes are in young, and for a time after the birth of the kids the old males wander off by themselves, and are very rarely seen. The voice of the males is a loud hoarse bark or "baugh" repeated several times in quick succession, and is a very characteristic forest sound; that of the doe is similar but less rough. Their sense of hearing is very acute, and their general wariness such that it is difficult to get near them; but when once driven out of cover they are not difficult to shoot, as they are heavy and rather deliberate in their movements; sometimes, when hard pressed, they take to the water and there swim well.

The food of the bushbuck consists, according to Kirby, of leaves of trees and shrubs, and also of succulent young grass, besides these, ground-nuts and pumpkins are much relished by them; they are also said to be fond of potato tubers, and to frequently pay nocturnal visits to gardens to root them up. The males are exceedingly pugnacious, both among themselves and when wounded or hunted, they will nearly always charge with often fatal results to dogs if these are present; instances even have been known of fatal accidents to beater's and hunters, as the horns are exceedingly sharp and quite capable of impaling a man.

In the neighbourhood of Port Elizabeth bushbuck are carefully preserved for sport and at certain seasons of the year are shot in organised drives. Near Port Elizabeth they appear to breed all the year round but further inland in other districts the breeding season is confined chiefly to the months between October and February.

In captivity the females are very docile, but the males almost invariably become savage and intractable.

The flesh especially of the does and kids is fairly good eating, though not nearly so palatable as that of the springbuck.

\section{Tragelaphus angasi. The Inyala.}

Tragelaphus angasi, Angas, Proc. Zool. Soc. 1848, p. 89, pls. iv, v; Proudfoot, Proc. Zool. Soc. 1850, p. 199; Brooke, Proc. Zool. Soc. 1871, p. 487, fig. 2 [skull and horns] ; Buckley, Proc. Zool. Soc. 1876, p. 285; Thomas, Proc. Zool. Soc. 1891 p. 387 ; Rendall, Proc. Zool. Soc. 1895, p. 359. 
Literature.-Angas (1849), large folio plate of Inyala with an account of its first discovery; Baldwin (1863), p. 76 and plate on p. 92, short descrip. tion of occurrence in Amatongaland; Drummond (1875) p. 378, with plate and account of shooting in Zululand; Nicolls and Eglington (1892), p. 39, pl. viii, fig. 28, description, distribution and habits ; Lydekker (1893), p. 252, description and distribution; Ward (1896), p. 200, horn measurements; Kirby (1899), p. 326, distribution in Mozambique; Selous and Neumann (1899a), pp. 455, 462, range and habits.

Vernacular Naves.-Inyala of the Zulus (Angas), and of the Mathlengas of Amatongaland (Proudfoot); and now usually adopted by the English Colonists ; said to be called the "Bastard Kudu" by the Dutch Colonists.

Description.-General colour, greyish brown, a good deal lighter than the male bushbuck, forehead and round the eyes bright sienna brown: a chevron shaped mark on the nose, several spots on the cheeks, either side of the upper jaw, the chin, and gullet white; ears oval, rufous tipped with black and fringed inside with white hairs; neck covered with long shaggy hair dark, almost black, extending under the belly and fringing the haunches to the knees; white tufts at the dewlap, under the belly, on the flanks and in front of the thighs; a dorsal mane of long hairs present, black as far as the shoulders, thence white, from this run about five white transverse lines encircling the barrel; forelegs with a black patch above the knee surrounded by three white spots, below the knee bright chestnut with two white spots on the fetlocks above the hoofs, hind limbs somewhat similarly coloured, hoofs normal, short black, and pointed, tail with long bushy hairs throughout, black above and at the tip, white below.

The female is a good deal smaller than the male, is without horns and of a general bright rufous almost orange colour, becoming rather paler below and on the insides of the hind legs; a line of black but not long hairs extends from the crown of the head to the root of the tail and from this radiate about thirteen pairs of white transverse markings round the barrel; a black patch from between the eyes to the tip of the nose; chevron mark in front of, and two spots below the eye, the upper and lower lips and chin white; tail rufous-orange above, and white below with a black tip; no mane or long hairs on any part of the body as is the male. Young, coloured like the female, but paler and more spotted.

Horns larger and rather more spreading than those of the bushbuck, and with a more open spire of three quarters of a turn only, brown, not black, with marked pale straw-coloured tips. 
Dimensions.--Of a female; head and body $4 \mathrm{ft}: 10 \cdot 5$, tail $14 \cdot 0$, with terminal hairs $18 \cdot 0$, height at the shoulder 38.0 ; of a male, according to Angas, 40.0 ; from ear to nose-tip 10.5 ; length of ear from notch $5 \cdot 75$; skull, basal length $12 \cdot 5$, breadth 5.90 .

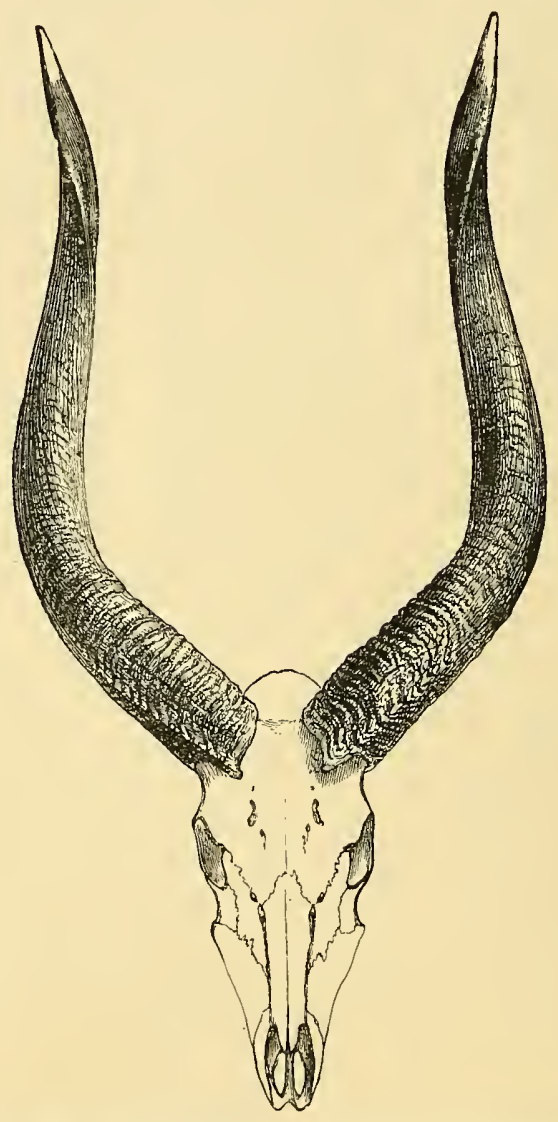

FIG. 60.-Skull and horns of the Inyala (Tragelaphus angasi).

(Proc. Zool. Soc.)

Horns average about 22 to $24 \mathrm{in}$. along the curve and $20 \mathrm{in}$. measured in a straight line; the largest pair given by Ward is $29 \frac{1}{2}$ along the curve measured on a pair from Delagoa Bay in the possession of Mr. Barber; another pair from Zululand attain $28 \frac{1}{2}$ in. along the curve and $23_{4}^{3}$ measured straight. 
Distribution and History.-The inyala was first brought to the notice of naturalists some years ago by a young Australian artist and traveller, Mr. George French Angas, and named by him in honour of his father, Mr. George Fife Angas. It was in the neighbourhood of St. Lucia Bay in Zululand that Mr. Angas came across this strikingly marked antelope, north of which place it appears to extend through Amatongaland to Delagoa Bay; recently it has been shot north of the Zambesi on the western banks of the Shire river near Chiromo; it probably will also be found in the Lake Mweru district, and in other suitable localities in the intermediate regions between these extreme points. The South African Museum possesses a mounted female from Amatongaland and skulls and horns from Zululand.

Habits.-The inyala is found only in low-lying and thickly forested country generally not far from water ; here it lives in small troops of eight to sixteen individuals, sometimes with an old male or two, while at other times the males run by themselves; like the bushbuck they are nocturnal animals and very seldom seen during the daytime; they feed chiefly on leaves, shoots and fruits, with perhaps occasionally a little grass, during the night only; they give vent to a sonorous bark like that of the bushbuck, though somewhat deeper in tone; when brought to bay with dogs they are very awkward to tackle, being very quick and vicious. Their flesh is excellent eating.

\section{Tragelaphus selousi. The Sitatunga.}

Tragelaphus sp., Layard, Cat. Mamm. S. Afr. Mus. p. 78 (1861).

Tragelaphus spekii, P. L. Sclater, Proc. Zool. Soc. 1864, p. 103, pl. xii, [juv.] (a fig. of homs and hoofs), [in part]; Kirk, ibid. 1864, p. 659; Brooke, Proc. Zool. Soc. 1871, p. 485, fig. 1, [skull and horns]; Selous Proc. Zool. Soc. 1881, p. 753; P. L. Sclater, Proc. Zool. Soc. 1890, p. 590, pl. xlvii [juv. o] ; Thomas, Proc. Zool. Soc. 1891, p. 388.

Tragelaphus selousi, Rothschild, Nov. Zool. v, p. 206 (1898).

Literature.-Andersson (1856), p. 449, described under the name of the "Nakong" ; Livingstone (1857), p. 204, also described as Nakong and as being plentiful on the Upper Zambesi in 1852; Baines (1864), p. 458, description; Nicolls and Eglington (1882), p. 40, pl. viii, fig. 31, description, distribution and habits; Bryden (1893), p. 506, distribution; Lydeklier (1893), p. 254, note on; Oswell in Badminton Big Game (1894) i, p. 122, gives an account of the early discovery and shooting of this buck; Ward (1896), p. 458, horn measurements ; Selous (1899), p. 470, range and habits. 
Vernacular Naires.-Waterskaap or Waterkudu of the Boers; Nakong of the Bechuanas and Tribes near Lake Ngami (Livingstone and Nicolls and Eglington); Purula, Unzuza and Sitatunga of the Barotse and natives along the Chobe (Selous); this last name is the one generally in use among English sportsmen.

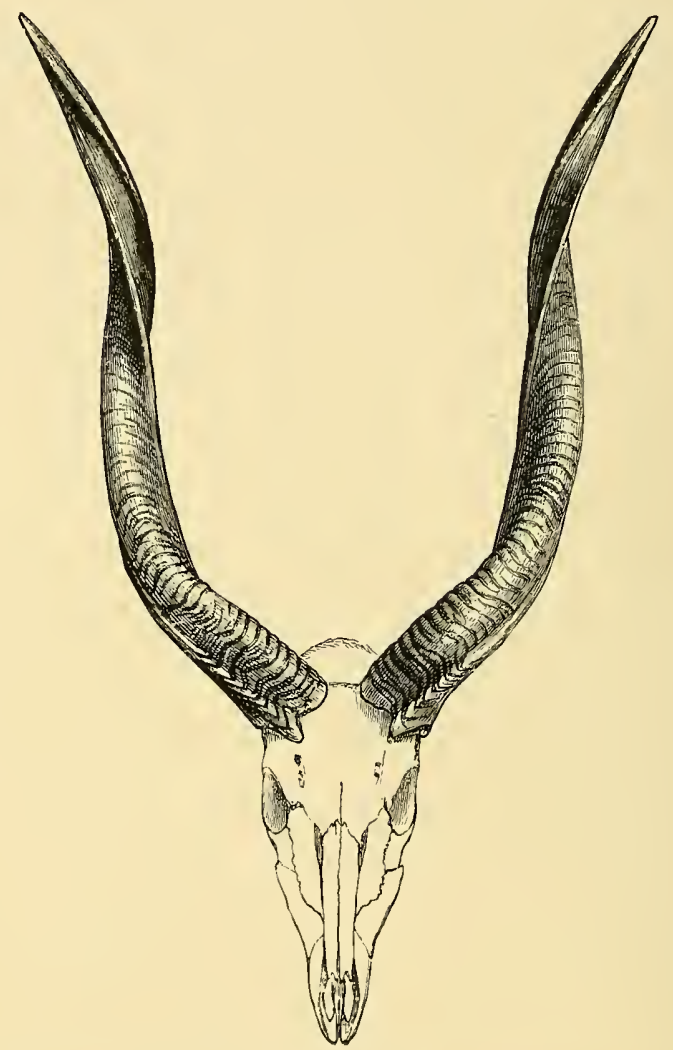

Fig. 61.-Skull and horns of the Sitatunga (Tragelaphus selousi).

(Proc. Zool. Soc.)

Description.-General colour above and below a pale sepia brown or mouse-colour; hair rather fine, long and woolly, giving the animal a somewhat shaggy appearance; face with an ill-defined $\mathrm{V}$-shaped mark from above the eye to the middle of the nose, a spot below the eye, the chin, two ill-defined transverse markings on the neck, two ill-defined markings on the insides of the legs and 
also about half-way down, all white; ears short and very broad, posteriorly brown with a white patch at the base of the outer margin, anteriorly white with a brown triangular-shaped marking in the middle of the outer margin, and a tuft of long white hairs along the inner one; all round the neck the hairs somewhat elongated forming an incipient mane; limbs like the back with white patches inside at the knees and hocks; feet very remarkable smooth and naked below between the false hoofs, which are large and well developed, and the true hoofs, which are enormously lengthened, the whole forming an elongated sole to enable the animal to support itself on the surface of the very marshy ground on which it lives; tail short and slender, brown above, white below. The female, unlike the others of the genus, resembles the male, except for the fact, of course, that it is hornless; the young animal is transversely striped with narrow white lines.

The horns are somewhat more twisted than those of the inyala or bushbuck, forming, when full grown, at least a one and a-half spiral; they are quite black in colour and have pale tips, which, however, are not so conspicuous as those of the inyala; the posterior ridge is well marked throughout, the anterior is very strong along the middle of the horn, and altogether the ridges are more developed than in the other two species of the genus.

Dimensions.-Of an adult male; head and body $5 \mathrm{ft} .3$; tail $4 \cdot 0$, with terminal hairs 6.0 ; height at the shoulders 42.0 ; from ear opening to nose-tip 11.5 ; ear from notch to tip 5.0 ; length of hoof of hind foot $4 \cdot 0$; skull, length $11 \cdot 75$, breadth $5 \cdot 0$.

Average horns measure about 27 along the curves, and about 22 in a straight line; the record, according to Ward, from the Chobe River in the possession of Mr. Selous, is $32 \frac{5}{8}$ along the curve and 27 straight.

Distribution.-The sitatunga within our boundaries is found only in the swamps between Lake Ngami and the Chobe and along the marshy banks of that river; beyond the Zambesi it is recorded from Lake Mweru and Bangweolo in northern Rhodesia. The South African Museum possesses a fine mounted male brought from Lake Ngami, and presented by Major Frank Johnston in 1895.

History.-The sitatunga was first met with by Dr. Livingstone in 1852 on the Zambesi, though Oswell, who accompanied Livingstone, states that they first came across the animal in the swamps north of Lake Ngami; however that may be, neither these travellers, Baines, nor Chapman and Green, all of whom mention the animal 
by name, seem to have given a proper description of it, and it was not till 1864 that a somewhat similar animal was described by Mr. P. L. Sclater from material obtained by Captain Speke on the western shores of Victoria Nyanza. Subsequently Sir John Kirk considered that the nakong of Livingstone was the same animal as Speke's antelope from Uganda. Recently, however, Mr. Rothschild has decided that the South African sitatunga is not the same as the Uganda form, since in the former the sexes are alike, while in the latter they are very different; he, therefore, has given the animal the new name it now bears.

Habits.-The sitatunga seems to be on the whole the most aquatic of all antelopes; it is found only in, or on the reedy shores of, the great lakes and swamps; here it lives in pairs or small family parties, spending the day hidden in the reeds, and only emerging at night to feed on the young shoots; owing to the peculiar structure of its feet above described it is able to support itself with facility on the matted vegetation of the swamps. It can also swim very well, but when on hard ground it is exceedingly awkward and cannot make any progress; if driven from its impenetrable haunts, which is often done by firing the reeds, it makes off with great splashing, and frequently tries to conceal itself by sinking its whole body under water, so that only its nostrils protrude; under these circumstances it is frequently pursued by the natives and speared. Its flesh is very rank and almost uneatable.

\section{Genus STREPSICEROS.}

Strepsiceros, H. Smith, Griff. Anim. Kingd. v, p. 365

Type.

S. capensis.

Large animals with the rhinarium between but not extending below the nostrils, with the antorbital gland and its opening very small; female with an udder of four mammae.

Horns which are present only in the male, with several open spirals, and with the anterior ridge more developed than the posterior. Skull with large and deep supra-orbital pits; moderate lachrymal fissures and brachyodont molars.

This genus closely resembles the last, from which in fact it differs merely in the greater development of the anterior horn ridge and in the more open nature of the spiral curve. 
In addition to the type species described below one other, the lesser kudu (S. imberbis) from Somaliland and other parts of North East Africa is known, while from the Pliocene beds of Northern India a third, fossil, species has been described.

\section{Strepsiceros capensis. The Kudu.}

Antilope strepsiceros, Pallas, Miscell. Zool. p. 9 (1766); Thunberg, Mem. Acad. Peters. iii, p. 317 (1811).

Antilope (Tragelaphus) strepsiceros, Desmarest, Mamm., p. 468 (1822). Damalis (Strepsiceros) strepsiceros, H. Smith, Griff. Anim. Kingd. v, p. 365 (1827) ; Smuts, Enum. Mamm. Cap. p. 92 (1832).

Damalis (Strepsiceros) capensis, A. Smith, S. Afr. Quart. Journ. ii, p. 223 (1834) ; A. Smith, Illustr. Zool. S. Afr. Mamm. pls. xlii, xliii (1844).

Strepsiceros kudu, Gray, List Mamm. B. M. p. 155 (1843); Gray, Knowsley Menagerie, p. 26, pl. xxiv, fig. 2 [juv] (1850); Layard, Cat. Mamm. S. Afr. Mus. p. 78 (1861); Buckley, Proc. Zool. Soc. 1876, pp. 284; 1877, 454; Selous, Proc. Zool. Soc. 1881, p. 751; P. L. Sclater, Proc. Zool. Soc. 1884, p. 46, fig. 2 [skull and horns].

Strepsiceros strepsiceros zambesiensis, Lorenz, Ann. kk. Hofmus. Wien ix, notiz. p. 63 (1894).

Literature.-Kolben (1731) ii, p. 115, described quite recognisably as " another sort of goat of the size of a large hart"; Buffon (1764) xii, p. 301, pl. xxxix, fig 1. skull and horns and (1782) Suppl. vi, p. 124, pl. xiii, general account of Kudu under the name of Condoma or Coedoes; Vosmaer (1783) Beschryving pp. 1-15, description with plate; Sparman (1785) ii, p. 231, note on the synonomy, habits and structure of the Kudu; Thunberg (1795) ii, p. 89, notes the Kudu as plentiful in Uitenhage; Daniell (1804), figured on pl. vi; Burchell (1822) i, p. 337, met with Kudu in Hay; Steedman (1835) ii, p. 128, gives a description; Harris (1838) p. 214, met with the Kudu in the Pretoria district of the Transvaal; Harris (1840), figured on pl. $x x$; Delagorgue (1847) i, p. 365, notes the occurrence of the Kudu in Zululand; Cumming (1855) i, p. 144, found the Kudu in Herbert division; Andersson (1856) p. 484, gives a plate with description and account of habits; Livingstone (1857) p. 56, notes that it can subsist without water; Grout (1863) p. 303, describes it with the Zulu name; Drummond (1875) p. 347, and appendix, hunting and Zulu name; Bryden (1889) p. 291, distribution in the Colony; Nicolls and Eglington (1892) p. 52, pl. i, fig. 1, description, distribution and habits ; Bryden (1893) p. 503, past and present distribution; Lydekker (1893) p. 256, description with figures; Millais (1895) pp. 99-101, 171, description of shooting in Mashonaland, with sketches and notes of habits; Kirby (1896) pp. 135, 548, native names, habits and hunting in Eastern Transvaal; Ward (1896) p. 204, horn 
measurements; Bryden (1897) p. 241, a chapter on hunting and habits; Selous (1899a) p. 440, range and habits.

Vernacular Nanes.-Kudu or Koedoe of the Hottentots, whence this has become the common name among both Dutch and English Colonists; Iqudu of the Amaxosa (Stanford) doubtless from the Hottentot; Umgakla (Grout) or Umgangxa (Drummond) of the Zulus; Itolo of Basuto (Kirby); Itshongonono of the Swazis (Kirby); Tolo of Bechuanas, Eebalabala of the Matabele, Eezilarwa of the Makalakas, and Noro of the Mashonas (Selous).

Description. - General colour pale ashy brown, becoming, according to Selous, a blue grey in the old males owing to the skin showing through the hair which is very short and thin; face a little darker; a chevron-shaped mark from around the eye extending across the nose, the upper lip, lower lip, chin, and a varying number of round spots below the eye on the cheeks white; ears very broad and flattened, anteriorly with a few short white hairs and a longer tuft of the same colour along the inner margin; neck thick and stout, with long dark brown hairs all round forming a kind of mane; a fringe of long hairs runs from the chin, where it forms a dark brown beard-like tuft, (which, however, often becomes scanty in old animals), to the chest, the hairs of the fringe itself being brown at the base and tip and whitish in the intermediate region; another fringe of long semi-erectile hairs extends from the occiput to the root of the tail, this as far as the shoulders is wholly dark brown, behind this point partly brown and partly white; from it radiate six or seven narrow transverse white lines surrounding the barrel and haunches; fore-part of the belly and breast very dark brown; limbs white inside, on the posterior side of the upper portion of the fore-legs and round the hoofs are somewhat ill-defined dark patches, false hoofs small and rounded, space between them and the true hoofs hairy, the latter being short, black, wide, rounded and compact; tail nearly reaching the hocks, not very bushy, brown above, white on the sides and below with a fairly-developed black terminal tuft.

The female resembles the male but is hornless and rather smaller; in the young animal the white spots and stripes are more numerous and more conspicuous.

The horns, which are situated on the top of the frontal bones, are stout and somewhat compressed, the anterior ridge being very strong, while the posterior ridge is practically absent; the horns vary considerably both in the size of the spiral and the distance of 
the tips from one another, this is very well shown in the illustrations and measurements given by Kirby, pp. 136, 137; here the measurements of two pairs of horns are given as follows :-

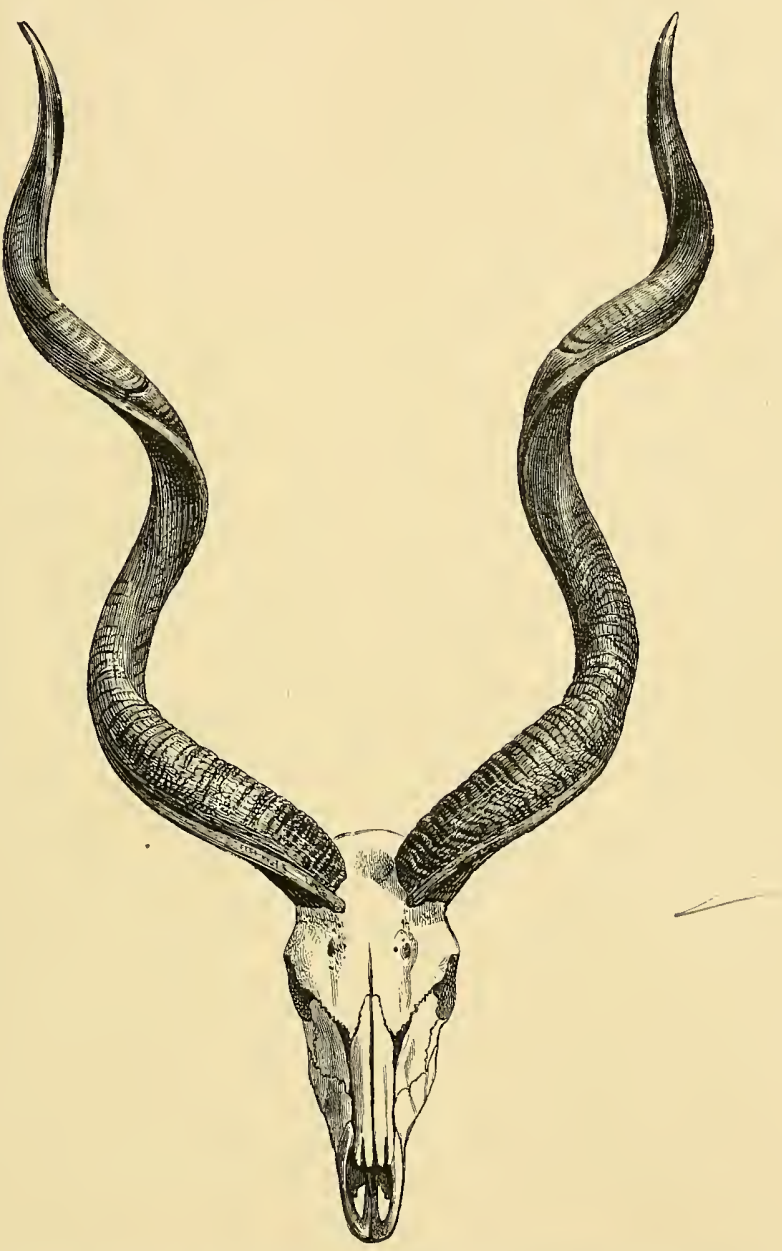

FIG. 62.-Skull and horns of the Kudu (Strepsiceros capensis). (Proc. Zool. Soc.)

$\begin{array}{lcc} & a & b \\ \text { Length in a straight line } \ldots \ldots \ldots \ldots \ldots \ldots \ldots \ldots \ldots \ldots & 44 & 39 \\ \text { Length along the anterior curve } \ldots \ldots \ldots \ldots \ldots \ldots \ldots & 58 & 60 \\ \text { Width between tips } \ldots \ldots \ldots \ldots \ldots \ldots \ldots \ldots \ldots \ldots \ldots \ldots & 44 & 7 \frac{5}{8}\end{array}$


" $a$ " is a head with a very close spiral and with very divergent tips, "b" a head with a very open spiral and almost parallel horns. In addition to this the horns vary in colour some being almost black, others being very pale; almost all, however, have white or very pale tips.

Females occasionally have been known to bear horns, one found dead by $\mathrm{Mr}$. Selous, having been killed by wild dogs near Bamangwato, is figured by Lydekker (1893), p. 257 ; in this as in other cases the horns are usually small and not symmetrical, one side being more twisted than the other. They are about an inch in diameter, smooth and round and without any keel.

Dimensions.-From a mounted male; length of head and body 8 ft. 2 ; tail 16.5 ; with terminal tuft 20 ; height at shoulder $4 \mathrm{ft} .7$; from ear opening to nose-tip 16; ear from notch to tip 9 ; breadth of ear 5 ; weight of an average male about $500 \mathrm{lbs}$. (Bryden).

Skull length 16.25 ; breadth 6.87 . Any horns over 40 measured in a straight line may be taken as a very good average; the longest pair recorded by Ward measure $48 \frac{1}{2}$ straight and 63 along the curve, and were obtained near Macloutsie on the northern frontier of the Bechuanaland Protectorate; Selous' best pair from the Umfuli River in Mashonaland, though only 41 straight had a larger spiral and so measured 64 along the curve.

Distribution.-The kudu is found throughout the greater part of southern and eastern Africa, extending from the Colony to Angola on the west and through Nyasaland, German and British East Africa to Somaliland and Abyssinia on the east.

Within our limits it is probably the most abundant and widespread of the larger antelopes; in the Colony it is to be met with in the southern districts from the Riversdale and Prince Albert divisions away eastwards to Albany and Fort Beaufort, where it is abundant in the bush country along the Koonap and Great Fish Rivers. In Griqualand West and Prieska in the northern part of the Colony it is also fairly abundant; in German South-west Africa, Bechuanaland, Rhodesia, the northern and eastern parts of the Transvaal, Portuguese territory and Zululand, it is also plentiful in suitable localities.

The mounted male in the South African Museum is from Barberton in the Transvaal, the female from Koonap in the Albany division of the Colony.

History.-The earliest mention of the kudu seems to be that of Kolben, who obviously refers to this antelope in his description of 
"another sort of goat" ; the next author who mentions the animal is Buffon, who first of all, in 1764, described a skull and a pair of horns which had reached him from the Cape under the name of the Condoma; subsequently in his supplement in 1782 , he repeats Allamand's description drawn up from a living specimen in Holland.

In 1776 the Governor of the Cape, Joachim van Plettenberg, sent to the Prince of Orange a kudu, which lived for some time in the Hague, and was there described and painted by both Allamand and Vosmaer, to whom we owe the first complete description of the animal. Pallas' account was founded only on heads seen by him at Leyden, and it was he who first designated the animal with the Latin name Strepsiceros, which was subsequently adopted as the name of the genus. Under these circumstances the earliest specific name available is "capensis" of Smith, which antedates "kudu" of Gray by nine years. The best modern accounts of the kudu will be found in Millais' and Kirby's books referred to above.

Habits.-The kudus, like their relatives the bushbuck and the inyala, are inhabitants of forest or dense bush, and are very seldom seen in the open; they seem to be particularly fond of rocky and stony hills covered with thick thorny shrubs, but are also found along the densely wooded river banks; as a rule they associate in small herds of from five to ten, or even twenty individuals, consisting of one or two males with several cows and calves of various ages, but under certain conditions or at certain times of the year; probably when the cows are in young, the males are found in small herds together. or even solitary; when this is the case the males often wander far afield away from water, but the females are more sedentary and remain near their accustomed drinking places.

The alarm cry is described by Millais as a loud roaring bark, something like that of a baboon but louder. Every one seems agreed that the pace of the males, at any rate in open country, is not very great or enduring, but they are very clever over rough ground and through thick thorn bush, making their way with great rapidity and unerring dexterity with the nose up and the horns lying back along the shoulders; they are also endowed with wonderful jumping powers, clearing obstacles as much as $8 \mathrm{ft}$. high at a single bound.

The food of the kudu seems to consist chiefly of the leaves and shoots of astringent shrubs and bushes, and also of wild fruits. Although often found far from water, and probably able to abstain from it for considerable periods, as a rule it drinks daily, according 
to Millais, where undisturbed, about an hour before sunset. Only one young one is born at a time.

The kudu is an exceedingly shy and timid animal, with very acute senses of smell and hearing, and great power of concealment, to which facts perhaps are due its survival in South Africa in such considerable numbers. Kirby states that they never use their horns against dogs or attempt to defend themselves, though Andersson and Smith both say that they do occasionally stand and charge.

The kudu's hide, though thin, is tough, and much valued for reins and harness; its flesh is generally reported to be good, and most sportsmen and naturalists mention the marrow bones as being particularly delicious.

\section{Genus TAUROTRAGUS.}

Oreas, Desmarest, Mamm. p. 471 (1822) [nec Montfort, 1808]

Type.

Taurotragus, Wagner, Schreber Säugeth., v, p. 438 (1855) Doratoceros, Lydekker, Ann. Mag. N. H. (6), viii, p. 192 (1891)

T. oryx. T. oryx. T. oryx.

Antelopes of very large size with the rhinarium extending down to the upper lip, but hardly above or below the nostrils; antorbital gland small with a very small circular opening in front of the eye in a narrow bare triangular space; a well developed dewlap present in both sexes. Females with an udder of four mammae.

Horns present in both sexes, those of the male stouter and usually shorter than those of the female, nearly straight, running back in a line with the face and surrounded by a spiral ridge, with traces of annulation at the base.

Skull not differing in any important respect from that of Strepsiceros.

Only two well defined recent species are recognizable, T. oryx described below and $T$. derbiamus from West Africa, distinguished by its larger size and horns.

\section{Taurotragus oryx. The Eland.}

(a) T. oryx typicus.

Antilope oryx, Pallas, Miscell. Zool. p. 9 (1766).

Antilope oreas, Pallas, Spic. Zool. xii, pp. 5, 17 (1777); Thunberg, Mem. Acad. Petersb. iii, p. 314 (1811). 
Antelope (Oreas) canna, Desmarest, Mamm. p. 471 (1822).

Damalis (Boselaphus) oreas et canna, H. Smith, Griff. Ann. Kingd. v, pp. 364-5 (1827) ; Smuts, Enum. Mamm. Cap. pp.90, 91 (1832) A. Smith, S. Afr. Quart. Journ. ii, p. 222 (1834).

Boselaphus oreas, Gray, List Mamm. B.M. p. 155 (1843) ; A. Smith, Illustr. Zool. S. Afr. Mamm. pls. xl, xli (1843).

Oreas canna, Gray, Knowsley Menagerie, p. 27, pl. xxvi, xxvii (1850) ; Layard, Cat. Mamm. S. Afr. Mus. p. 78 (1861); Buckley, Proc. Zool. Soc. 1876, p. 284 ; Selous, Proc. Zool. Soc. 1881, p. 749 ; Barkley, Proc. Zool. Soc. 1894, p. 131.

Antilope triangularis, Gunther, Proc. Zool. Soc. 1889, p. 73 [with figure].

Doratoceros triangularis, Lydekker, Ann. Mag. N. H. (6) viii, p. 192 (1891) ; P. L. Sclater, Proc. Zool. Soc. 1896, p. 506.

\section{(b) T. oryx livingstonii.}

Oreas livingstonii, P. L. Sclater, Proc. Zool. Soc. 1864, p. 105; id. ibid. 1883, p. 32.

Literature.-Kolben (1731) ii, p. 110 gives a rather absurd account of the Eland under the name of the "Elk," from the mountains near Cape Town; Buffon (1764) xii, p. 357, pl. xlvi bis, figures the horn under the name of "Coudou," and further (1782) Suppl. vi, p. 116, pl. xii, figures the animal under the name of "Canna," with a good description from Allamand ; Vosmaer (1783), describes and illustrates an individual sent alive to the menagerie of the Prince of Orange; Sparman, k. Vet. Akad. Handl. xl, p. 155 (1779), and also (1785) ii, pp. 75, 221, gives a good account of the structure and habits of the Eland as observed by him in the Alexandria and Somerset East divisions of the Colony; Paterson (1790), pp. 9, 54 and 81, records meeting with Elands near Hanglip in Caledon, in Vanrhynsdorp and in Uitenhage in about 1777; Thunberg (1795) ii, p. 58, met with Elands in Uniondale; Lichtenstein (1812) i, p. 97, ii, pp. 23, 39, in Calvinia in 1803, Aberdeen and Middelburg in 1804; Burchell (1822), i, pp. 309, 417, ii, pp. 42, 81, met with Elands in Prieska, Herbert and Britstown, and found them numerous in Hanover in 1812; Steedman (1835), i, p. 209, details of distribution in the Colony; Moodie (1835), ii, p. 144, notes its existence in Alexandria; Harris (1838), pp. 75, 158 and 262, distribution in the Transvaal and Bechuanaland; Harris (1840), figured on pl. vi ; Delagorgue (1847), i, p. 365, found Elands in plenty in Zululand; Methuen (1848), p. 118, habits in the Kalahari near the Molopo River; Livingstone (1857), p. 56, notes the Eland as a buck which can subsist without water; Drummond $(1875)$, pp. 138, 178, devotes a chapter to the hunting and habits of the Eland; Theal (1888), i, p. 51, notes that according to van Riebeck, Elands were found on Table Mountain in 1652; Bryden (1889), p. 291, extinction in Cape Colony; Nicolls and Eglington (1892) p. 54, pl. vi, fig. 21, description, 
distribution and habits; Bryden (1893), p. 501, the present and past distribution; Selous (1893), p. 91, notes and measurements of a large specimen from Mashonaland; Lydekker (1893), p. 258, description and figure of horns; Kirby (1896), p. 549, note on distribution and native names in the eastern Transvaal; Ward (1896), p. 211, horn measurements; Bryden (1897), p. 213, general acconnt ; Kirby (1899), p. 325, distribution in Portuguese South Africa; Selous (1899a), p. 421, habits and range.

Vernacular Names.-Eland of Dutch and English, the word being the Dutch term for the European Elk (Alces machlis), and originally wrongly applied to the present animal; Canna or T'ganna of the Hottentots ; Impofu of Amaxosa (Stanford); of the Matabele (Selous); of the Zulus and Swazis (Kirby) ; Pofu of the Bechuanas (Selous) ; and Basutos (Kirby); Eepofu of Makalakas and Mofu of Mashonas (Selous).

Description.-Of a male from Mashonaland which should be referred to T. oryx livingstonii. The largest and heaviest of all antelopes, general colour varying from a pale fawn to a bluish grey according to age, the latter colour due to the increasing thinness of the hairs which allow the blue-black skin to show through with advancing age; on the forehead extending half way down to the nose, a kind of brush of reversed upstanding hairs of a very dark brown or black colour, the front and sides of the snout also black or nearly so; ears rather small, acutely pointed, with a few long white hairs along their inner margins and slightly darker posteriorly; neck enormously thickened with ample deposits of fat, especially dorsally, over which part the hairs are somewhat longer and darker, and form an incipient mane ; below, the neck is produced into a very prominent rounded dewlap which is ridged along its edge with long dark hairs. A dark line runs along the back from the occiput to the root of the tail, the anterior part as far as the shoulders being marked by longer hairs forming a dorsal mane; from the dorsal line there run transversely ten to twelve white lines or stripes round the barrel. Limbs massive, a dark patch inside and behind above the knee on the forelimbs; false hoofs large and pointed, true hoofs thick, ox-like and rounded with a ring of dark brown hairs above and around them ; tail long and slender, nearly reaching the hocks covered with short hairs like the body and ending in a bushy black tuft of long hairs.

Female much smaller, horned, but without the face brush or swollen neck of the male; udder with four mammae.

Horns of the male short but massive, running back in a line with the face, straight, with a strong spiral ridge running round the lower half of them, traces of transverse rings at the base 
only; horn of the female similar but much more slender and often longer.

Dimensions.-Of a mounted male from Mashonaland; head and body $10 \mathrm{ft}$. 2 ; tail $2 \mathrm{ft}$. 4, with terminal hairs $3 \mathrm{ft} .2$; height at shoulders $5 \mathrm{ft} .7$; ear to nose 20.0 ; ear from notch to tip 8.0. Selous measured the height of a large bull at the withers $5 \mathrm{ft} .9$. Barrow and Harris both mention $6 \mathrm{ft}$. 6 , but this,

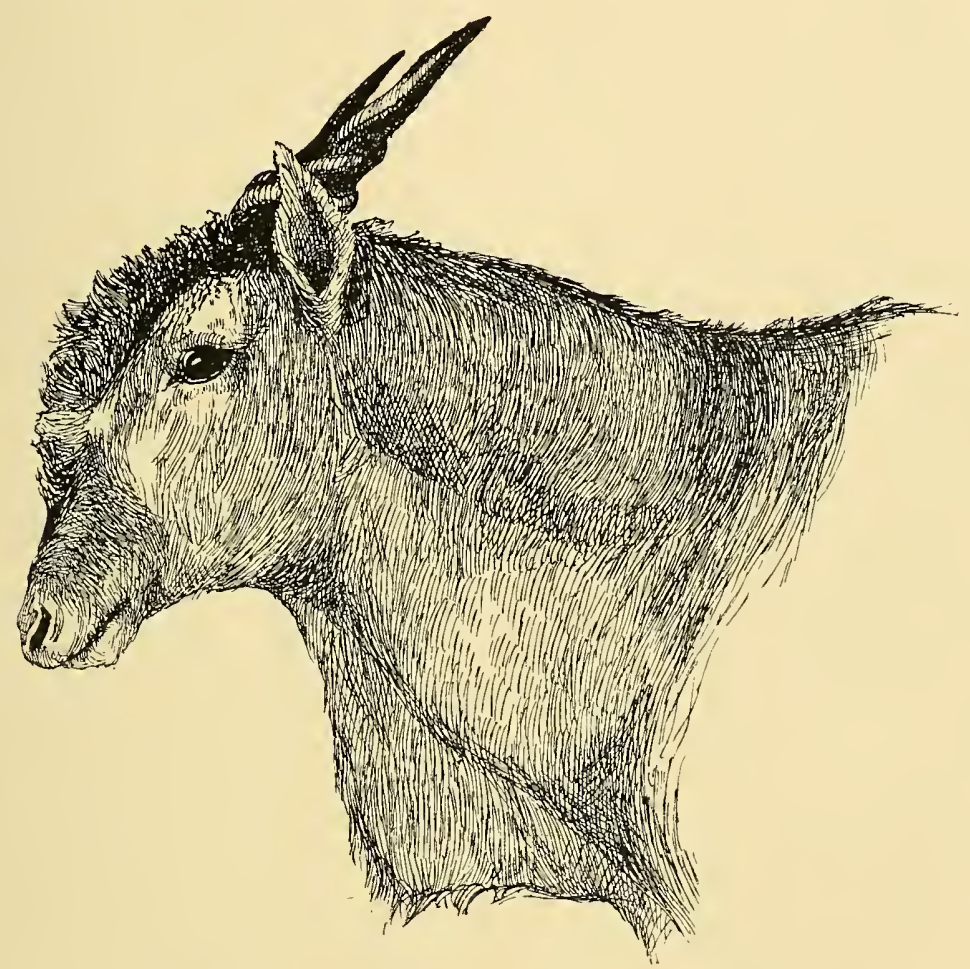

Frg. 63.- Head of a male Eland (Taurotragus oryx).

I think, is doubtful; the cow in the South African Museum measures $4 \mathrm{ft} .9$ at the shoulders.

The skull of a female measures 16.25 in length by 7.0 in extreme breadth.

Horns of the male average about 24 inches in length, those of the female a little more; the longest recorded by Ward measure 
$40 \cdot 0$, but these are probably referable to the West African T. derbianus.

Mr. Selous states that the longest pair of bull horns met with by him belonged to an animal shot in Mashonaland in 1887, by a Boer hunter; these reached a length of 33.0 ; the longest pair of cow horns measuring 34.0 were those of an animal shot by $\mathrm{Mr}$. Selous himself in the Northern Kalahari.

Distribution and Geographical Races.-The eland was formerly found all over South Africa, including the Colony. In 1652, when the Dutch East India Company founded the settlement of the Cape of Good Hope, van Riebeck, the first Governor, or, rather, Commander, records in his diary, recently published, that there were many elks or elands in the neighbourhood of Cape Town, and even at the end of the last century Colonel Gordon (according to Buffon) stated that there were still some in the Hottentot's Holland, and Paterson relates that they existed near Cape Hanglip in what is now the Caledon divison. In the early part of the present century Burchell saw a good many in the northern Karoo districts, and in 1835 Steedman recounts meeting with them on the Bontebok flats in the Queenstown division.

At the present time there are still a few left in the mountainous country along the Basutoland, Griqualand East, and Natal borders ; beyond the Colony there are a certain number in the North Kalahari, in Ovampoland, Rhodesia, and the country between Beira and Mozambique, and possibly in Zululand and the Transvaal Eastern frontier; elsewhere they have been nearly exterminated. North of the Zambesi the eland's range extends to Angola on the west, and to Kilima-njaro, and, perhaps, the upper waters of the Nile on the east.

The elands from the north of the Zambesi, and also those of Mashonaland and the Beira district, are as a rule distinguished from those of the Kalahari and the Colony by the presence of transverse white markings, and also by the dark mark on the foreleg; and it has been proposed to separate the striped form under a separate name, T. livingstonii; most observers however, state that the white bands are of varying distinctness, and by no means always present even in those districts where Livingstone's eland should be found; so that it will be best to separate the striped form as a sub-species only.

The curious horns, which have been described under the name of Antilope or Dorotoceras triangularis, are now generally considered to 
be abnormal products of the female eland; these horns are almost straight, and not twisted at all, but triangular in section throughout the lower half and then gradually becoming circular towards the tips.

The South African Museum, in addition to horns and skulls, possesses a mounted pair of Livingstone's elands obtained by Mr. Selous in Mashonaland in 1883.

History.-The eland has been known since the earliest days of the Dutch Settlement; it is frequently alluded to in the journal of van Riebeck (translated into English by Mr. Liebbrandt, and published by the Cape Government in 1897-8), the first Commander of the Cape (1652-63); Kolben also alludes to the animal. Buffon, in his earlier volume, figured a horn under the name of "Coudou," stated to come from India, but subsequently reprinted Allamand's account, which was derived chiefly from Colonel Gordon, and was accompanied by a quite recognisable figure. In the meantime the Dutchman Vosmaer published a description from living specimens brought to Holland for the Menagerie of the Prince of Orange in 1748 , and again in 1780 . The original Latin name bestowed on the eland by Pallas was founded on one of the skeletons of the animals imported in 1748 and preserved in the Leyden Museum, but the name oryx was given under a misapprehension and was subsequently transferred to the Gemsbok (Oryx gazella); while that of oreas was substituted for the present species. According to the strict laws of nomenclature, however, an author cannot alter a name once given even by himself, and the specific name, therefore, must remain "oryx." With regard to the generic name, Oreas, hitherto usually adopted, is inadmissible, as it had been previously used in Zoology; we are forced, therefore, to fall back on the later name, and the eland should thus be designated Taurotragus oryx.

Habits.-The eland is found both in the open desert country, such as the Kalahari, and also in mountainous districts such as exist on the frontiers of Natal and Basutoland; apparently the favourite localities are forest-clad rolling sand belts with open spaces here and there; the eland runs in troops of varying sizeformerly as many as 200 have been seen together, now, however, 10 to 15 form the usual number of which one or two are adult males; sometimes a troop consists of young males alone; when disturbed they usually retreat to the mountains. The pace of the young males and females is fair, but the old males are, as a rule, so overloaded with fat that they are quite easy to run to a standstill- 
so much so that it is said that they sometimes drop down dead in their paces; in the old days a skilful hunter would drive an individual right up to the waggons before dispatching it to save the carriage of the meat. Drummond recounts in his book how he ran a male eland down even on foot. When disturbed elands invariably make off in single file the younger ones leading, the old males bringing up the rear, and, moreover, they always run up wind.

In Mashonaland during the early part of the year the elands are scattered about in twos and threes in the rugged hills covered with thick forest and coarse grass below the level of the high plateaus; they are then in the best condition and very difficult to get near; but in June the natives burn off the grass on the high plateaus, and the elands, collecting into larger herds, leave the shelter of the hills and forest and wander over the open downs in search of the sweet young grass which immediately springs up. They now fall off in condition very rapidly, and can be ridden down and shot.

Where opportunity offers, they drink regularly during the night or at daybreak, but there is no doubt that in the Kalahari and other waterless districts they are able to manage without water, obtaining, doubtless, what liquid they need from the bulbs and watermelons, like the gemsbuck and the springbuck.

Only one calf is produced at a birth, generally in the month of July or August, or in Mashonaland, even in June, and the females there have been said to breed only once in two years, though those in captivity in Europe have in many cases calved annually.

Elands are very wary and difficult to approach; furthermore they are generally accompanied by rhinoceros birds (Buphaga), which by their flutterings and excitement warn them of the impending danger. They are absolutely timid and harmless, never attempting to defend themselves according to most observers, though Drummond states that females with calves will sometimes attack dogs with their horns. The flesh of the eland is always reported to be the best game meat in South Africa, that of the old males being loaded with fat; the hide, too, is much valued for making leather.

\section{Subfamily BOVINAE.}

This subfamily contains the oxen and their allies and is distinguished by the horns, which are present in both sexes, being 
rounded or angulate but never knotted or ringed; suborbital gland absent, rhinarium very wide and well developed, the nostrils being lateral; males generally with a dewlap.

\section{Genus BOS.}

Bos, Linnaeus, Syst. Nat. 12th ed. i, p. 98 (1766)........... Ty. taurus.

Bubalus, H. Smith, Griffith's An. Kingd. v, p. 371 (1827)

[nec Bubalis, Cuvier 1816] ........................... caffer.

Animals of large size with massive bodies and stout limbs, rhinarium broad, so that the nostrils open almost laterally, no antorbital or inguinal glands, tail long and tufted; female with four mammae.

Horns present in both sexes, rounded or angulate [never annulated] and outwardly directed; skull without any trace of the antorkital fossa usually present in the antelopes; molars hypsodont with a large inner accessory column.

This genus is usually split up by modern authors into several; but the distinctions are hardly of generic rank. Our only representative belongs to the Bubaline section which contains the true buffaloes confined to the Ethiopian and Oriental regions including Celebes.

The other living African species of the genus are $B$. aequinoctialis from Central and North-east Africa, rather smaller and less black than the Cape buffalo and doubtfully distinct except as a geographical race, and $B$. pumilus, the dwarf buffalo of West Africa still smaller again, of a bright yellow colour, extending as far south as Cape Lopez in French Congo.

Almost the only described South African fossil representative of the whole class of mammals is a species of this genus, Bubalus baini, Seeley (Geol. Mag. (3) viii, p. 199, 1891) originally noticed by Mr. A. G. Bain as having been found $40 \mathrm{ft}$. below the surface on the banks of the Modder River, in the Orange Free State. The original specimen is still preserved in the South African Museum, and is remarkable for the great length of the horn cores, each of which measures $5 \mathrm{ft} .2$ in length; the species seems to be very closely allied to, if not identical with Bos antiquus, Duvernoy, from the Pleistocene beds of Algeria and not very distantly related to the South African living species. 


\section{Bos caffer. The Cape Buffalo.}

Bos caffer, Sparrman, K. Vet. Akad. Handl. Stock.holm xl, p. 79, pl. iii, fig. 2 (1779); Thunberg, Mem. Acad. Petersb. iii, p. 318 (1811); Smuts, Enum. Mamm. Cap., p. 95 (1832); Grill, K. Vet. Akad. Handl. Stockholm ii, 2, p. 19 (1858) [Knysna]; Lydektier, Wild Oxen, p. 94, pl. vii \& fig. 17 (1898).

Bos (Bubalus) caffer, H. Smith, Griff. Anim. Kingd. v, p. 371 (1827); A. Smith, S. Afr. Quart. Joum. ii, p. 234 (1834).

Bubalus caffer, Gray, List Mamm. B. M., p. 153 (1843) ; Layard, Cat. Mamm. S. Afr. Mus. p. 81 (1861); Blyth, Proc. Zool. Soc. 1866, p. 371; Brooke, Proc.Zool. Soc. 1873, p.480, fig. 4, 「woodcut of skull], 1875, p. 457 ; Buckley, Proc. Zool. Soc. 1876, p. 289, 1877, p. 455 [distribution]; Pechuel-Loesche, Zool. Jahrb. iii, p. 705, pls. xviii, figs. 1, 2 (1888).

Literature.-Kolben (1731) ii, p. 109, account of the Buffalo and of a hunt of one close to Cape Town in 1705; Buffon (1754) xi, p. 416, pl. xli, fig. 4, description and figure of horn ; Sparrman (1785) i, p. 298, ii, p. 65, pl, ii, fig. 2, account of the Buffalo as observed in Zitzikamma and Alexandria, with measurements, notes and description; Paterson (1790), p. 9, met with Buffaloes near Hanglip in the Caledon division in 1777; Thunberg (1795) ii, p. 84, note on shooting in Uitenhage ; Lichtenstein (1812) ii, p. 276, met with in Hay; Burchell (1822) ii, p. 249, note on the structure, met with in Hay; Harris (1838), p. 87, met with in the Marico district of the Transvaal; Harris (1840), figured on pl. xiii; Delagorgue (1847) i, pp. 365, 480, met with in large numbers in Zululand; Methuen (1848), p. 161-3, description and measurements ; Cumming (1855) i, p. 243, met his first Buffalo at the head waters of the Marico River in Bechuanaland; Hall (1857), p. 10, distribution and habits ; Livingstone (1857), p. 56, asserts that it is always found near water; Drummond (1875), p. 1, account of habits and hunting in Zululand; Selous (1881), p. 277, account of habits and hunting in Mashonaland; Nicolls and Eglington (1892), p. 72, pl. iii, fig. 10, description, distribution and habits ; Bryden (1893), p. 496, past and present distribution; Lydekker (1893), p. 41, note on; Jackson, Badininton Big Game (1894), i, p. 214, account of habits and hunting; Kirby (1896), p. 549, native names, habits and measurements in the eastern Transvaal; Ward (1896), p. 262, horn measurements ; Kirby (1899), p. 325, distribution in Portuguese East Africa; Selous (1899a), p. 102, habits and range in South Africa.

Vernacular Names.-Buffalo of English, Buffel of Dutch Colonists; Qu'araho of Hottentots (Smuts); Inyati of Zulus (Drummond) ; Swazis (Kirby) and Matabile (Selous); Nari of Basutos (Kirby) and of Bechuanas (Burchell).

Description.-General appearance bulky and oxlike, with no marked ridge or hump at the shoulders; body very thinly covered 
with black hairs, rather thicker on the face, neck, and along the middle of the back, the skin, which is a dark grey black, showing through almost everywhere; head massive, facial line somewhat convex, rhinarium very large, extending well above, but not much below the nostrils, which are separated by a considerable space; skin of the throat somewhat loose and flabby, forming an incipient dewlap; ears drooping, of moderate size, rather broad, nearly naked within, hairy behind, generally much torn and slit; limbs

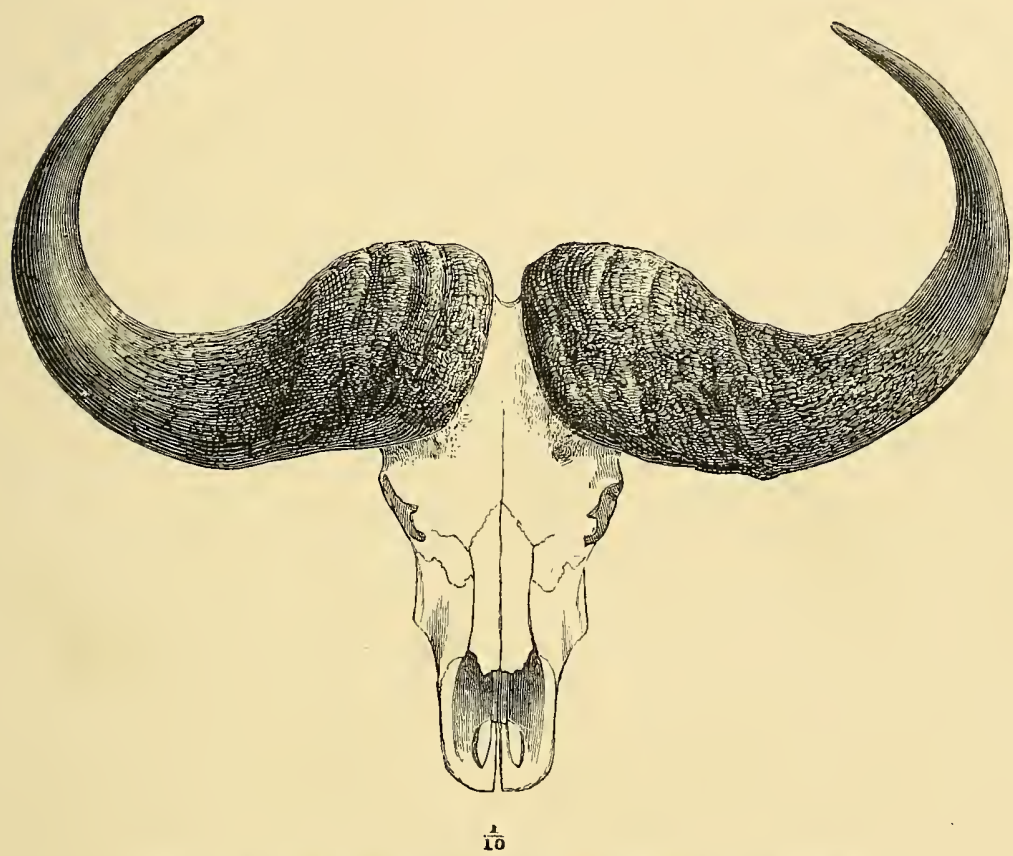

FIG. 64.-Skull and horns of a male Buffalo (Bos caffer).

(Proc. Zool. Soc.)

massive, with broad and rounded hoofs and with pointed welldeveloped false hoofs; tail reaching the hocks, thinly clothed with short hairs ending in a considerable brush.

Female smaller, and with a generally lighter and browner tinge to the hair, horns smaller, and udder with four mammae.

Young, reddish, and much more thickly clothed with hair than the adult, becoming black at about 3 years. Very old animals quite hairless. 
Horns of the male very massive, the basal portions or palms which are very rugged with annulations and longitudinal striae, sometimes meeting in the middle line of the forehead; the direction of the horns is outwards and downwards for the first two-thirds, the tips which are nearly smooth are turned up and directed back almost parallel to the basal portion, though as a rule inclined backwards to a certain extent; the horns of the female are generally similar in shape and direction, but the basal portions do not form the large palms, nor do they encroach at all on the forehead as in the males.

Dimensions.-Of a mounted male; head and body $9 \mathrm{ft.} 1$; tail 28.0, with terminal hairs 37 ; height at the shoulders $59 \cdot 0$; from ear-opening to nose-tip 20 ; ear from notch $8.0 \mathrm{long}$, about $5 \cdot 0$ broad. The height of a female at the shoulder is $54 \cdot 0$.

The skull of a male measures 19.0 long by 9.50 broad.

Horns of good males measure about $30 \cdot 0$ along the inside curve by 12 across the palm; of females 26.0 by 7 . The record male, according to Ward, is one obtained by Mr. F. Barber from the Sabi River, which measures 43.3 by 12 ; Mr. Selous' largest female head from the Chobe River measured $28 \cdot 0$ by $7 \cdot 0$.

Distribution.-The buffalo was formerly found throughout the southern and eastern parts of the Colony, Natal, and in fact all over South Africa in suitable localities, i.e., where there is plenty of water. Kolben states that they were common close to Cape Town in his day, and Paterson at the end of the last century met with them in Caledon. At the present time there are still a considerable number in the Addo and Kowie bush, in the districts of Uitenhage, Alexandria, Bathurst and Albany; also in Zululand, Damaraland, Rhodesia and the Beira Province. They appear to be exterminated in Bechuanaland and in the Transvaal, though a few years ago there were a good many along the Sabi river in the eastern Transvaal. Beyond our limits the Cape buffalo extends to Angola on the west, and through Nyasaland and East Africa as far as the Uganda Road and Mount Elgon; owing, however, to the ravages of rinderpest it has become very rare throughout the greater part of East Africa.

Drummond states that the buffaloes in a certain district (Umbeka) in North-east Zululand are smaller and more dangerous, and of a much more rufous colouration. The South African Museum possesses a mounted pair from Mashonaland, obtained by $\mathrm{Mr}$. Selous in 1884, a mounted skeleton from the Addo bush 
obtained in 1896, and skulls and horns from Knysna where it appears to be now extinct.

History.-Kolben gives the earliest account of the buffalo, and he is followed by Buffon who, however, only figures a horn brought from the Cape by the Abbé de la Caille. To Sparrman we owe our first connected account of the animal which he studied from fresh specimens killed in the Zitzikamma forest, and to which he affixed the scientific name it has since borne. Of modern accounts, those of Drummond, Selous and Jackson, the last in the "Big Game" volume of the "Badminton" series, are perhaps the best and fullest.

Habits.-The buffalo is seldom found far from water, and prefers a thorn country with plenty of intervening open ground, where there is pasture and shelter, to thick bush country. Buffaloes associate in herds of from 50 to 200 individuals, though old males are often found solitary, and sometimes a few males will be found together; the large herds consist of a few males with many females and calves of various ages. These herds are constantly accompanied by the rhinoceros bird (Buphaga), and also by the white egret (Herodias garzetta), which perch on their backs and heads in search of grass-ticks and other insect parasites, and often by their cries warn them of impending danger. Associated with the buffalo too is the tsetse fly (Glossinia morsitans); but it is now generally believed that the Haematozoon, which causes the ngana or tsetse fly disease, is found naturally in the buffalo, the blood of which seems to have become immune to the parasite, and that the fly is merely an involuntary carrier of the infection from the immune blood of the wild buffalo to the highly susceptible blood of the domestic animal. However this may be, ngana or tsetse fly disease seldom occurs except in the close neighbourhood of buffalo and other large game. Buffaloes drink regularly usually about sunrise, they then retire to a sheltered spot and rest during the day; in the evening they again drink and bathe, and then feed till midnight, when they rest and chew the cud till dawn. They are exceedingly fond of wallowing in the pools and plastering themselves with mud, possibly this assists them to get rid of the gad flies and other insect parasites with which they are afflicted; considering their bulk their pace is fairly swift.

During the breeding season the old males fight with considerable vigour as witnessed by Drummond; the single young one is born a good deal later than in the case of the antelopes, as a rule 
in February or March, and for about ten days the mother hides the young one in long grass, remaining in the vicinity and visiting it at constant intervals; soon after which the calf is able to run with the rest of the herd.

The buffalo is generally reckoned the most dangerous of South African animals, at any rate there can be no doubt that more lives have been lost in buffalo shooting than in any other form of sport, but this perhaps may be accounted for by the fact that it has been more hunted than any other animal. A few instances are recorded of the animal charging without provocation, this probably is due to the memory of previous attacks, but as a rule they only charge when wounded, and even then only when not more than fifty yards away from their assailant, as the senses of sight and hearing, especially in the old males, seem to be rather deficient. When charging the buffalo does not lower his head but keeps his nose forward and his horns directed backwards over his back, and just before reaching his object suddenly twists his head round sideways and endeavours to impale his foe. There can be no doubt that most of the accidents that have occurred in buffalo shooting are due to want of care in approaching wounded animals lurking in cover.

\section{Family GIRAFFIDAE.}

The characters of this family will be found detailed under the description of the genus, the only one among existing animals.

\section{Genus GIRAFFA.}

Type.

Giraffa, Brisson, Reg. Anim. p. 60 (1762)...........G. camelopardalis.

Animals of very remarkable proportions with greatly elongated necks, which, however, contain only the usual number of seven vertebrae; with high withers and short bodies; frontal appendages present in both sexes, consisting of a pair of short erect bony processes at the junction of the frontal and parietal bones ossified from distinct centres, though often afterwards united to the skull; these are covered with a hairy skin, and though often known as the horns are hardly to be rightly so called; in front at the junction 
of the nasal and parietal bones is a third median bony prominence also covered with skin and hair, more developed in the northern than the southern form, this is ordinarily known as the third horn.

There are no traces of the lateral digits or of the false hoofs on either the fore or hind limbs.

Dentition.-i. $\frac{0}{3}$, c. $\frac{0}{1}, \mathrm{pm} \cdot \frac{3}{3}, \mathrm{~m} \cdot \frac{3}{3}=32$; there are no upper canines or incisors, the lower canines resemble the incisors imme-

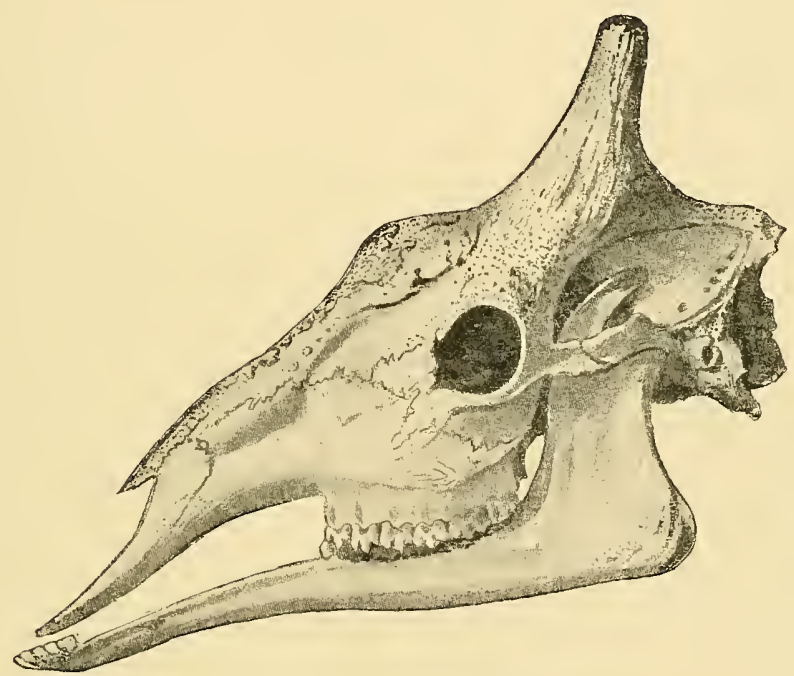

Frg. 65.-Skull of the Sonthern Giraffe (Giraffa capensis).

(From de Winton, Proc. Zool. Soc.)

diately preceding them and follow them without interval, the molars are brachyodont (i.e., short fanged) and the upper ones have no inner accessory column.

Although the giraffe is so well known an animal, it is only recently that the differences separating the Northern or Ethiopian from the Southern African form have been generally recognised, though as far back as 1822 they were pointed out by the French naturalist, E. Geoffroy St. Hilaire.

Mr. de Winton who has given a very clear account of the matter, shows that- 
In the Northern Form.

(1) The dark body markings are polygonal with very well defined edges, and that the pale intervals get narrower and more defined as age advances.

(2) Legs below the knees and hocks white.

(3) The third "horn" well developed from 3 to 5 inches in height in the males.

(4) Skull of the $\delta$ with a third horn, of the o with no unossified space in front of the orbit, of both sexes with the posterior edge of the bony palate rounded.
In the Southern Form.

(1) The body markings are more blotchy, the middle being darker than the edges, and these are never really well defined.

(2) Legs spotted to the hoofs.

(3) The third " horn" merely consists of a slight lump or prominence in the males.

(4) Skull of the $\delta$ with only a low prominence, of the $q$ with a marked unossitied lachrymal space, of both sexes with the posterior edge of the palate pointed.

These differences seem sufficient to constitute specific separation, and this conclusion has been here adopted.

In addition to the living species strictly confined to the Ethiopian region, fossil forms have been recorded from the Pliocene beds of Greece, Persia, India and China, showing the former wide extension of this very specialised family.

\section{Giraffa capensis. The Southern Giraffe.}

Giraffa camelopardalis, Zimmemann, Geogr. Geschichte ii, p. 125 (1780) (in part); Layard, Cat. Mamm. S. Afr. Mus. p. 67 (1861); Bryden, Proc. Zool Soc. 1891, p. 445 [distribution]; Thomas, Proc. Zool. Soc. 1894, p. 135 ; P. L. Sclater, Proc. Zool. Soc. 1895, p. 161 ; [nec Linnaeus].

Camelopardalis giraffa, Smuts, Enum. Mamm. Cap. p. 67 (1832) ; A. Smith, S. Afr. Quart. Journ. ii, p. 184 (1834).

Camelopardalis capensis, Lesson, Nouv. Tảbl. Regn. Anim., p. 168 (1842).

Giraffa australis, Rhoads, Proc. Acad. Philad., 1896, p. 518 (1897).

Giraffa capensis, de Winton, Proc. Zool. Soc. 1897, p. 277, figs. 3 and 4 [head and skull].

Literature.-Buffon, vol. xiii. (1765), p. 9, earliest mention of the giraffe in South Africa; id. Suppl. iii. (1776), p. 320, figure and account of young specimen sent by Governor Tulbagh to Holland and described by 
Allamand; id. Suppl. vii. (1789), p. 345, another figure with account derived from Colonel Gordon; Brink and Hop (1778), p. 26, account of the first discovery of the South African giraffe in 1761; Sparrman (1785), ii, p. 256, account also derived from Colonel Gordon with criticism on Buffon; Vosmaer (1787), history and description with plates of animal and skeleton; Paterson (1790), pp. 64, 126, account of two individuals shot north of the Orange River with descriptions and measurements, one of which was sent to John Hunter for the Hunterian Museum; le Vaillant (1796), ii, pp. 267, 280-1, account of hunting north of the Orange River with notes on several points, a plate of the head, and an allusion to the individual sent by Governor Tulbagh to Allamand in Holland; Lichtenstein (1812), ii, p. 277, met the giraffe in Griqualand West, and asserts that le Vaillant did not kill his specimen but purchased the skin in the Karee Mountains, south of the Orange River; Harris (1838), pp. 103, 143, and 158, met with and shot the giraffe in what are now the Marico and Rustenburg districts of the Transvaal, p. 227, chapter 24 is devoted to an account of hunting giraffe; Harris (1840), figured on pl. xi; Methuen (1848), pp. 124, 168, habits and shooting near the Molopo River in Bechuanaland; Cumming (1855), i, p. 268, account of first giraffe shot near "Booby" in the South-eastern Kalahari, p. 306, another $18 \mathrm{ft}$. high shot in Bagmanwato forests; Andersson (1856), p. 83, account of appearance and pace, p. 413, account of lions attack on; Hall (1857), p. 166, note on distribution; Livingstone (1857), p. 56, asserts that giraffe are always near water; Baines (1864), p. 387, on the smell of the giraffe ; Selous (1881), p. 230, account of habits, distribution and hunting; Theal (1888), ii, p. 165, account of Hop and Brink's Expedition to Great Namaqualand in 1761 and of the shooting of giraffes, the skin of one of which was sent by Governor Tulbagh to Holland [see Buffon above]; Bryden (1889), p. 285, evidence in favour of the giraffe having once existed south of the Orange River; Nicolls and Eglington (1892), p. 69, distribution and habits in Bechuanaland; Bryden (1893), p. 304, chapter on hunting in Khama's country, pp. 322, 498, on its past and present distribution and habits; Oswell (1894), Badminton big game hunting, i, p. 48, gives measurements and notes on hunting in Livingstone's time; Kirby (1896), p. 329, an account of the habits, p. 540, native names and distribution in the eastern Transvaal; Bryden (1897), p. 127, chapter on giraffes and how to capture them; Gibbons (1897), pp. 395-6, distribution in Barotseland; Bryden (1899), p. 496, account of giraffe in South Africa.

Vernacular Names.- Kameel of the Dutch; Naip of the Hottentots (Harris); Tuthla of Basutos (Kirby) ; and Bechuanas (Bryden); Intutla of Matabele (Harris); Ihuhla of Swazis (Kirby); Indhlulamiti [i.e., he that surpasses trees] of Zulus (Kirby); Ng'habe of Masarvas (Bryden).

Description.-General colour varying from pale chestnut to very dark chocolate, the females and young males being as a rule the lightest in colour; the markings consist of large, irregularlyshaped blotches darker in the middle than at the edges, separated 
by ill-defined pale tawny lanes; the upper line of the face uniformly brown, the cheeks paler; the spots extend down nearly to the hoof, but become smaller and fainter; nostrils placed at the top of the snout, slit-like, with no bare rhinarium surrounding them, closable at the will of the animal ; tongue very long and slender and extensile; eyes very large; horns or frontal apppendages with a tuft of long black hairs at their tips, third "horn" little developed consisting only of a slight prominence between the eyes; a short erect mane runs from the nape of the neck to the withers and is of a chestnut colour; tail long and strong ending in a tuft of coarse black hairs ; feet large and heavy with no traces of lateral hoofs.

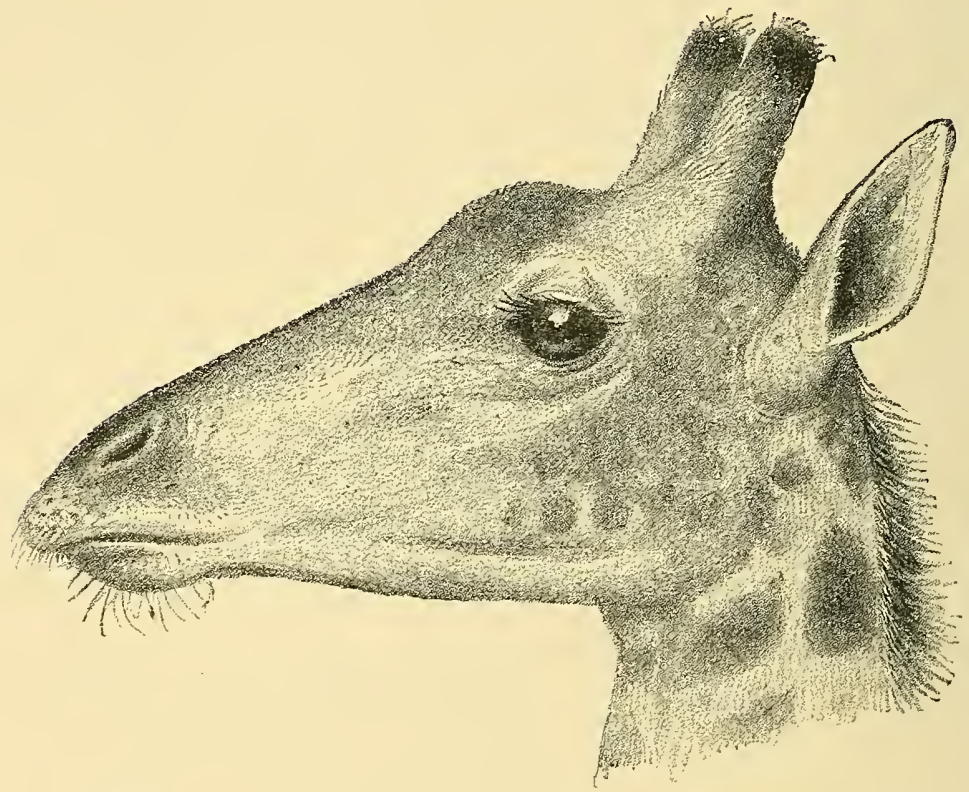

FIG. 66.--Head of the Male Southern Giraffe (Giraffa capensis).

(From de Winton, Proc. Zool. Soc.)

The female differs from the male in size and is usually lighter in colour, also the median prominence or third horn is almost entirely absent.

Dimensions.-Kirby carefully measured an old male from the crown of the head to the hoof, $18 \mathrm{ft}$. 7 ; Bryden gives $18 \mathrm{ft} .11 \frac{1}{2}$; the height of females is from $15 \mathrm{ft} .6$ to $16 \mathrm{ft}$; the length of the 
tail $4 \mathrm{ft}$.; the skull of an old male in the South African Museum measures as follows, length from condyle to premaxillae, 26; greatest breadth, 12; length of upper cheek teeth 6 ; height of bony "horn" prominence, $7 \cdot 5$.

Distribution.-The Southern giraffe was formerly found throughout the country north of the Orange River up to the Zambesi. Brink, le Vaillant, Colonel Gordon and Paterson, at the end of the last century, all found giraffes immediately after crossing the Orange River into Great Namaqualand, and Lichtenstein a little later records it from Griqualand West. There does not seem to be any evidence of the occurrence of this animal south of the Orange River; Bryden, who discusses the matter, can find no better argument than the bushman pictures in some caves near Graaff Reinet, but there is no doubt that bushmen illustrated animals seen during their devious wanderings over the country, and by no means confined themselves to those in the immediate neighbourhood. Harris and Cumming in the middle of the century found plenty of giraffes in what is now the eastern part of Bechuanaland and the western Transvaal.

At the present time giraffes are still found in the northern Kalahari in the neighbourhood of Lake Ngami, and also further north to and beyond the Zambesi ; there may also be a few in the western part of Matabeleland. Up to a year or two ago there were plenty of giraffes in the Sabi River district of the eastern Transvaal, whence came the living examples now in the Zoological Gardens. If any are still surviving there now, they are strictly preserved; in Portuguese East Africa and further south in Zululand there are also said to be some.

Immediately north of the Zambesi the giraffe has not hitherto been recorded either in Nyasaland or Mozambique, but north of the Rufiji River it again appears, and is found fairly abundantly in German and British East Africa as far as the Tana River, north of which it is replaced by the Nubian species (Giraffa camelopardalis).

History. - The giraffe was known to the later classical writers and is noticed by Pliny, Oppian, and others, the best description being that of Heliodorus, Bishop of Tricca, in his "Ethiopica;" it was exhibited in Rome by Julius Caesar, and in the fifteenth century in Florence by Lorenzo di Medici.

The existence of the giraffe in the southern part of Africa was first made known by the expedition sent by the Governor Tulbagh, under Brink and Hop, to Namaqualand in 1761 ; notice of a rude sketch made by them will be found in the 13th vol. of Buffon; 
subsequently Tulbagh procured a specimen for the Leyden Museum, and another complete skin and skeleton, obtained by Colonel Gordon for the Prince of Orange, was described by Vosmaer ; le Vaillant and Paterson again obtained others. No living example of this form however, was imported into Europe till quite recently, i.e., in 1895, when the animal now living in the Zoological Gardens in London was safely landed.

The name giraffe, derived according to Skeet from the Arabic Zaref or Zarefat, is practically unknown in South Africa where the term "kameel" is always used.

Habits.-Many sportsmen have written on the habits of this most interesting animal, Kirby's account is on the whole the best and most detailed; the following notes are drawn up from this and the other authors cited above.

Giraffes are found in comparatively dry open country where there are frequent sandy ridges overgrown with "kameel dorn" (Acacia giraffae), "mopani" (Copaifera mopane) and other desert shrubs and trees. They feed chiefly in early morning and late evening, resting during the heat of the day; they are exceedingly difficult to distinguish, their long necks and heads almost exactly resembling dead and branchless tree-stumps, and this difficulty is further accentuated by the fact that they often remain perfectly still without any movement of their ears or tail which so often betrays the presence of other big game animals.

They associate in herds or troops of from seven to sixteen individuals though occasionally even larger numbers are seen together; these herds usually contain only one old male the others being young males and females; the very oldest males called stinkbulls by the Boers are often found solitary; the herds of giraffe are frequently found in association with zebra, wildebeest and ostrich, and in addition the red-billed weaver bird (Textor erythrorhynchus) is a constant attendant on the giraffe, clinging to its withers and fluttering along by its side when galloping off.

The giraffe is a very defenceless animal, the only weapon it ever uses appears to be its heels, with which however, it can give a very powerful kick; besides man the lion appears to be its only enemy. Nicolls and Eglington state that it is chiefly the females in young who thus suffer as they seem to require water more frequently than the others, and the lions lie in wait for them in the thickets by the rivers and pools. Andersson relates that he once saw a giraffe with a lion on its back, and figures the incident.

Their pace, though not appearing to be so, is very considerable, and even with a good horse it takes some time to ride them down. 
They always gallop moving the fore and hind legs of the same side at the same time, their long necks swinging stiffly to and fro like gigantic pendulums as they move; their tails switch round and curve up over their backs so that the whole movement is a very remarkable one, and is compared by some observers with a ship rolling about in a heavy sea. As they move their hind legs are somewhat straddled so that it is dangerous to come too near their heels.

All observers seem agreed that the giraffe is mute, but their sense of both sight and smell is very acute; the old males, as before indicated, have a very strong odour; Cumming rather poetically compares it with that of a "hive of heather honey," Bryden with that of musk, but there can be no doubt that to horses it is exceedingly overpowering and disagreeable, and further, that when an old male is killed it is quite impossible to endure it.

The food of this animal consists almost entirely of the leaves of an acacia (A. giraffae) commonly known as the kameel-dorn, the leaves of which are plucked off one by one by its long flexible tongue. There has been a good deal of controversy about the drinking of the giraffe, it seems on the whole that though in certain districts it does not drink during the greater part of the year, yet, that where water is available it does so freely.

The female produces but one calf, though Kirby has twice exceptionally observed twins; the period of gestation, as ascertained from animals in captivity, is about fourteen months, and the young are born, according to Kirby, usually between November and February.

The giraffe is nearly always hunted and shot on horseback; a stalk is almost an impossibility owing to the great height of the animals which enables them to overlook trees or any other shelter. Most hunters record a bullet planted directly from behind about 15 inches above the root of the tail as most effective; owing to the peculiar shape of the animal this will run right forward along the body and pierce the heart.

\section{Division SUINA.}

Artiodactyles with incisors generally present in the upper jaw; with bunodont molars [i.e., with conical cusps when unworn]; with a comparatively simple stomach not arranged for ruminating; with the third and fourth metacarpals and metatarsals distinct from one another, and the second and fifth toes usually complete though smaller than the two median ones. 


\section{Family HIPPOPOTAMIDAE.}

Animals of bulky form with smooth and nearly hairless skin and with a broad and somewhat square muzzle with no disc-like termination as in the pigs; feet short and broad with four subequal toes, each provided with a short rounded hoof, all of which reach the ground when the animal is walking.

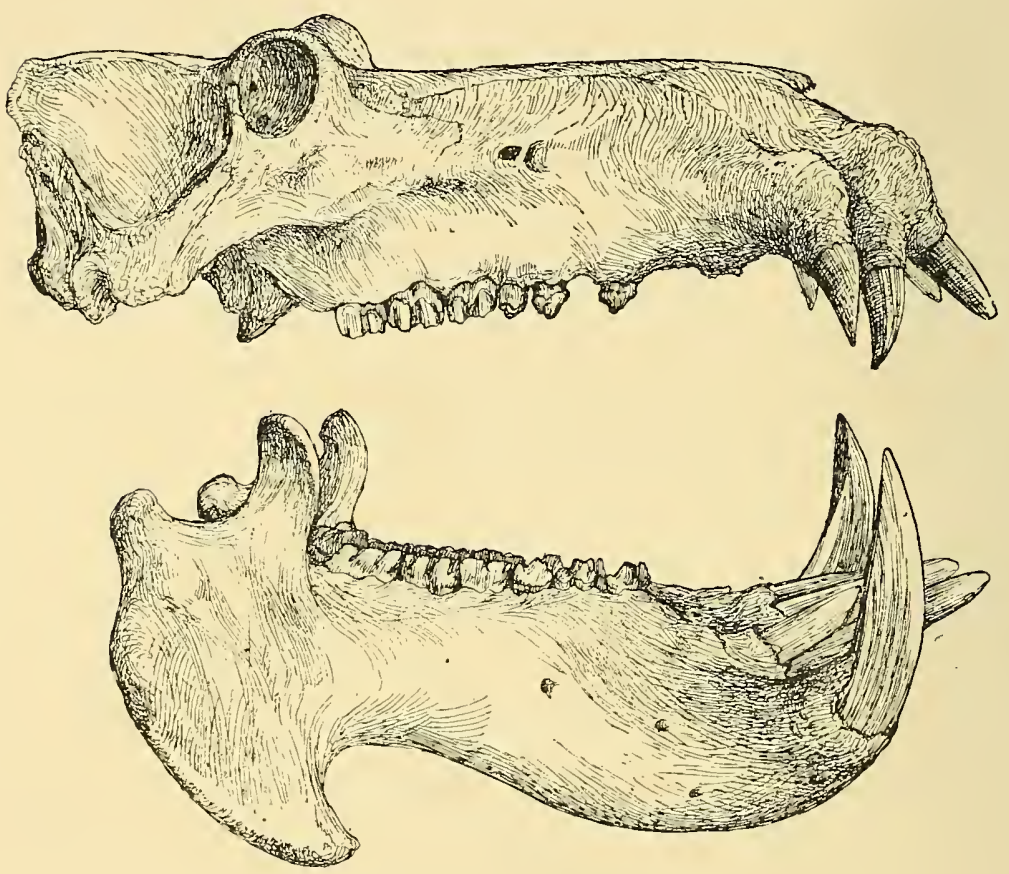

FIG. 67.-Skull of Hippopotamus amphibius ( $\frac{1}{9}$ nat. size).

Skull with facial portion much elongated, the orbits tubular and very prominent; the mandible large and heavy with a rounded descending process at its outer angle. Dentition i. $\frac{2-3}{1-3}$ c. $\frac{1}{1}, p m \cdot \frac{4}{4}$, m. $\frac{3}{3}$, incisors and canines not rooted and continually growing, the lower canines very long and heavy, the lower incisors more or less horizontally placed ; premolars somewhat pointed, molars when worn, flat and showing an infolded outline of enamel. 


\section{Genus HIPPOPOTAMUS.}

Hippopotamus, Linnaeus Syst. Nat., 12th ed. i, p.

H. amphibius.

The characters of this the only recent genus of the family will be found enumerated above.

In addition to the well-known species described below there is a much smaller one, the Pigmy Hippopotamus (H. liberiensis) from the rivers of West Africa.

Both the existing forms are confined at the present time to Africa ; in the later geological eras, however, hippopotamuses were found all over the Old World, a species practically indistinguishable from the larger living form, having been met with even in the Pleistocene beds of England.

\section{Hippopotamus amphibius. The Hipropotamus.}

Hippopotamus amphibius, Linnaeus, Syst. Nat. 12th ed. i, p. 101 (1766) ; Smuts, Enum. Mamm. Cap. p. 58 (1832) ; A. Smith, S. Afir. Quart. Journ. ii, p. 177 (1834); id. Illustr. Zool. S. Afr. Mamm. pl. vi. (1838) ; Murray, Proc. Zool. Soc. 1849, p. 163, pl. xiv; Layard, Cat. Mamm. S. Afr. Mus. p. 60 (1862); Bartlett, Proc. Zool. Soc. 1871 , p. 255, pl. xx, 1872, p. 819 [account of birth of young one].

Hippopotamus capensis, Desmoulins, Joumal de Physique, v. p. 354 (1826).

Literature.-Tachard (1686), p. 104, noticed and figured as the "vache marine" ; Kolben (1731), ii, p. 129, described as the sea cow and figured in a woodcut, abundant near Cape Town at that time; Buffon (1776), Suppl. iii. p. 301, gives an account of two specimens brought from the Cape, one sent by Governor Plettenberg to the Prince of Orange, the other previously sent to the Leyden Museum; Brink and Hop (1778), p. 18, figures Hippo met with to the north of the Orange River in 1761; Paterson (1789), pp. 84, 88, met with a few Hippos on the Sunday River and many on the Fish River; Sparrman (1785), i, p. 370, on its occurrence in the Krom River in Humansdorp division, ii, p. 300, hunting and general account on the Fish River in the Albany and Somerset East Divisions; Thunberg (1795), i, p. 207, Hippos on the Gantoo River in Humansdorp in 1772; Barrow (1801), i, p. 186, met with Hippos on the Great Fish River ; Lichtenstein (1812), i, p. 49, notes that there were ten or twelve in the Berg River in 1803, ii, p. 42, gives an account of hunting in the Orange Piver near Colesberg; Burchell (1822), i, p. 411, met with Hippos in 1811, in the Vaal 
River, and gives an account of their capture and cutting up; Harris (1838), p. 84, met with Hippos on the Molopo River in Bechuanaland, and again p. 208, on the Upper Limpopo in the Pretoria District of the Transvaal; Harris (1840), figured on pl. xii ; Delagorgue (1847), i, pp. 120, 146, 304, 326, 455, gives a good account of the habits of the Hippo in Natal where he met with it on nearly all the rivers, from 1839 onwards; Methuen (1848), p. 230, met with on the Marico River; Gordon Cumming (1855), ii, pp. 164, 181, shot Hippos on the Upper Limpopo river ; Andersson (1856), p. 510, description and account of habits; Hall (1857), p. 9 on distribution; Grout (1863), p. 295, notes as still found at the Umgeni River mouth near Durban; Farini (1886), p. 463, saw Hippos in Orange River; Theal (1888), i, p. 42, in his history notes that Hippos were killed in the marsh where Church Square Cape Town now is in 1652; Bryden (1889), p. 288, discusses the present distribution of the Hippo in South Africa; Nicolls and Eglington (1892), p. 65, distribution and habits; Bryden (1893), p. 495, on its past and present distribution; Selous (1893), p. 161, met with $4,000 \mathrm{ft}$. above the sea up the rivers in the dry season in Phodesia; Jackson (1894), i. p. 269, chapter on methods of hunting ; Kirby (1896), p. 538, note on habits and occurrence in the eastern Transvaal; IVard (1896), p. 299, measurements of incisors; Gibbons (1897), p. 8, measurements, p. 396, and distribution in Barotseland; Kirby (1899), p. 336, distribution in Mozambique; Selous (1899), p. 533, range and habits.

Vernacular Names.-Zeekoe of the Dutch, Sea-cow of the European colonists; T'gao of the Hottentots (Sparrman); Imvubu of Amaxosa (Stanford) ; of Zulus (Delagorgue); Swazis (Kirby); and Matabele (Selous) ; Ikubu of Basutos (Kirby); and Bechuanas (Harris).

Description.-Of large size covered with smooth and very thick skin, dirty or greyish black above, getting lighter below with a fleshy pink tinge here and there, especially in young animals; the skin is quite hairless except for a few tufts on the lips at the sides of the head and neck, at the tips of the ears and the extremity of the tail.

The head is very large and square, the nostrils which can be opened and closed at the will of the animal, being situated on the top of the snout; the eyes which are comparatively small, are somewhat protruding owing to the projecting bony orbits, and placed almost in a line between the nostrils and the ears; these latter which can also be closed at the will of the animal, are exceedingly short as if cropped, and bear a row of hairs along their margins.

The legs are short and only raise the ponderous abdomen a short distance off the ground; the tail is short and somewhat compressed and naked, except for a few bristles at its extremity.

The skull is very massive and provided with two pairs of incisors 
above and below, the central pair being considerably longer than the outer ones.

The female resembles the male, but is always smaller.

Dimensions.-The average measurements of the hippopotamus seem to be from 11 to $12 \mathrm{ft}$. in length; Sir A. Smith gives the following--head and body $10 \mathrm{ft}$. 3, tail $13 \mathrm{in}$., height at shoulder $4 \mathrm{ft} .8$; a male which lived many years in the Zoological Gardens, in London, measured head and body $12 \mathrm{ft}$., tail 22 in., and weighed 4 tons; a very large one according to Gibbons measured $14 \mathrm{ft} .0 .5$ in extreme length; the lower canines are very large and heavy,

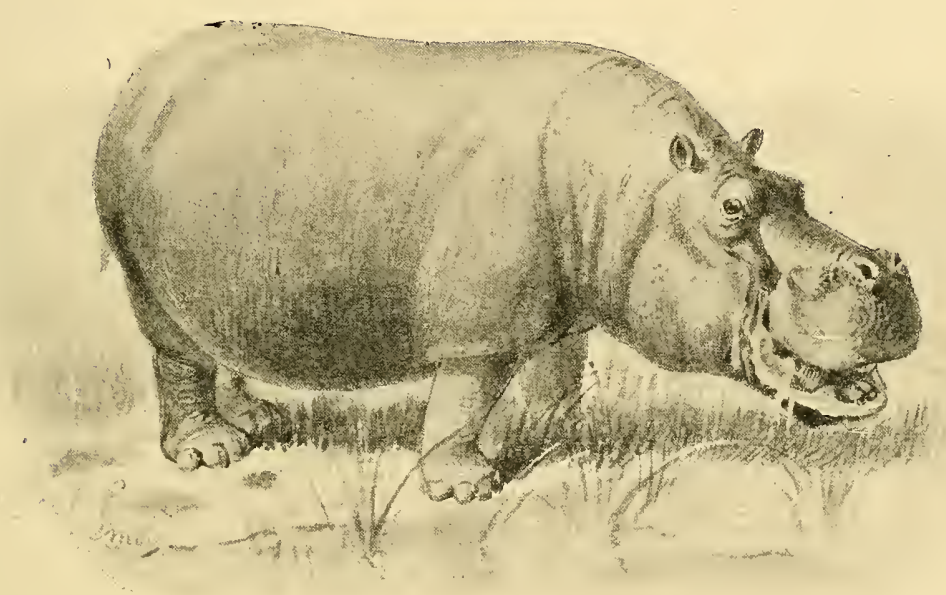

FIG. 68.-The Hippopotamus (Hippopotamus amphibins).

the record given by Ward is 37.5 from the Shire River, Kirby records a pair from an individual shot by himself on the Zambesi 31.25 and 31 ; a pair a little smaller weighed, according to Ward, $15 \mathrm{lbs}$.

A very large skull from St. Lucia Bay in Zululand, now in the South African Museum, measures, length $2 \mathrm{ft} .7$; breadth, $1 \mathrm{ft} .6 .5$; length of cheek teeth, 11, the portion of the lower canines projecting from the lower jaw measures 14 and 1.3 respectively.

Distribution.-The hippopotamus was formerly found throughout Africa, south of the Sahara, in suitable places, and also in the 
Nile down to its mouth, but owing to natural shyness and persecution it has now retreated from the more populous and frequented districts, and is only as a rule found in places of less easy access.

In South Africa it was originally found everywhere along the coasts and rivers; Theal, in his history records from van Riebeck's Diary that in 1652, hippopotamuses disported themselves in the swamp now occupied by Church Square, in the centre of Cape Town; even in the early part of the 18th century Kolben speaks of them as being not uncommon in the neighbourhood, but with the great expansion that took place in the middle of that century the hippopotamus retreated, and Paterson, Sparrman, and the other travellers had to go nearly as far as the Great Fish River before meeting these monsters; Burchell witnessed a sea-cow hunt close to where the Vaal and Orange Rivers meet, but Harris and Cumming, 1830-40, only came across them in the upper waters of the Limpopo and its tributaries.

A few individuals lingered for many years near the mouth of the Berg River almost 70 miles north of Cape Town; and the head of one killed in 1856, is still preserved in the South African Museum, and the last is said to have disappeared about 1874.

Nowadays, except for a few said to be still surviving in the lower reaches of the Orange River, the hippopotamus may be regarded as extinct in the Colony; in Natal there are a few strictly preserved in "Zeekoe lake" at the mouth of the Umgeni River a few miles north of Durban; north of this, especially in St. Lucia Bay, in the Komati and other rivers, in the eastern Transvaal and Portuguese territory up to the Zambesi, they are still found in reduced numbers in less frequented districts as also in the upper waters of that river, the Okovango and the Ngami swamps.

History.-The hippopotamus is one of the oldest known animals, if Behemoth of the Book of Job is to be identified with it as seems very probable; to the classical authors Herodotus, Aristotle and Pliny, the "river horse" was well known, though the descriptions given are not very good, and many fabulous tales are mingled with them.

Kolben was apparently the first author to identify the South African sea-cow with the classical " river horse," and his description though quaint is fairly accurate; after his time nearly all authors dealing with South Africa have something to say on this subject; on the whole Delagorgue (1847) and Harris (1840) give the best account of the history and habits of this animal. 
Habits.-Sea-cows are thoroughly aquatic in their habits, being seldom found far from water either of rivers, lakes, or even the sea, along the shores of which they frequently travel from one river mouth to another; during the day where entirely unmolested they are often found asleep on mud or sand banks, but in more frequented places they sleep actually in the water, either floating with only the nostrils above water or even, according to some authors, lying on the river bed and rising to the surface only from time to time. Along many of the rivers of South Africa are to be found deep pools which retain their water even in the dry season, these which are known as "zeekoegats" are no doubt partially excavated by the animals themselves, and here they were often to be found in considerable numbers. Occasionally the sea-cows make a kind of narrow ditch up the river, along which they can travel from one "gat" to another; during the rainy season they go far up the rivers to near their sources, as is remarked by Mr. Selous, who came across one at an elevation of about 4,000 ft. above the sea in Rhodesia; during the dry season they retreat back to the lower reaches and mouths of the rivers.

In the evening the sea-cow leaves its gat, and travelling by narrow but well defined paths seeks its food, often going for this purpose considerable distances even as much as ten or twelve miles from the river bank; it usually gets back to the river before morning.

Notwithstanding its ungainly shape the pace of this animal on land is considerable; Delagorgue asserts that on flat ground it is equal to that of an average active man; it swims, of course, with great facility, and owing to its specific gravity being almost equal to that of water it is able to walk along the bottom of the rivers rising to breathe only at considerable intervals; Kirby indeed states that he has observed one remain submerged for twelve minutes.

The voice of the hippopotamus may be described grunting roar, and is compared by some with that of an elephant. Its food consists entirely of herbs, grasses, and young branches of shrubs-never of fruits or roots; to fill its enormous bulk it requires a very large quantity of material, and in addition it spoils a good deal more than it eats; in cultivated lands such as rice fields and sugarcane plantations it does a terrible lot of damage, and its visits are consequently much dreaded by natives.

During the breeding season the males become fierce and attack one another by biting, never by ripping with their lower canines 
as do the true pigs ; the period of gestation as observed on several occasions in the Zoological Gardens, varies, from 227 to 242 days, and only one young one is born at a time; a graphic description of this event will be found in Mr. Bartlett's paper quoted above; the mother carries the young one mounted on her back when in the water, this has been observed both in captivity and in the wild state.

In disposition the hippopotamus seems to be peaceable and inoffensive, though when wounded or molested it has been known to charge; it is also very dangerous to passing canoes and boats in some of the larger rivers, this is especially the case on the Shire and Zambesi, where several bad accidents have occurred owing to the upsetting of the boats of passing travellers.

The hippopotamus is usually shot in the water from the river bank, but when killed the body sinks immediately, often not floating again for eight to ten hours. Andersson gives an account of harpooning from canoes, and also of killing by the drop of a loaded javelin suspended from a tree branch by the natives near Lake Ngami.

All authors, from Kolben and Burchell onwards, are agreed that the flesh of the hippopotamus is excellent eating, closely resembling succulent pork or veal; there is also a layer of fat between the muscles and the skin very much prized by natives and colonists alike; it is termed "zeekoe speck," and must be salted at once in order to preserve it.

From the hide of the sea-cow are made the sjamboks or whips so much sought after, and from the teeth the hardest ivory is procured, formerly much used by dentists in their arts.

\section{Family SUIDAE.}

This family containing the pigs and their allies is distinguished by the possession of a snout, ending in a distinct, more or less round, naked disc within which the openings of the nostrils are placed; the feet are narrow and slender, each bearing four hoofs, of which the two middle ones (those of the third and fourth toes) are rather larger and have their contiguous faces flattened so as to form a symmetrical pair, the outer smaller pair (those of the second and fifth toes) never under ordinary circumstances reach the ground.

The incisors are always rooted; the canines are large, those of 
the upper jaw usually curving round and directed upwards and outwards, and together with the lower ones forming what are termed the tushes.

The molars which are oblong in shape are covered with a number of little rounded elevations of enamel, so that with wear the tooth surface shows a series of irregular enamel surfaces.

The mandible is not provided with the descending hooked process present in the hippopotamus.

\section{Key of the South African Genera.}

A. No warts or lobes on the face, incisors present throughout life.

Potamochoerus, p. 273.

$B$. Two pairs of warts or fleshy lobes on the face, incisors of both jaws very much reduced in the adult and nearly always absent in old animals Phacochoerus, p. 276.

\section{Genus POTAMOCHOERUS.}

Potamochoerus, Gray, Proc. Zool. Soc., 1852,

Type.

p. 131 P. choeropotamus.

Choiropotamus, Gray, Ann. Mag. N. H. (2) xi.,

p. 281 (1852)

P. porcus.

Pigs with sharply pointed ears more or less tufted with a pencil of hairs, and with in the old males a pair of hard callosities or swellings on the side of the face between the eyes and the snout, caused partly by the great development of the sheath of the upper canine, and partly by a mass of cartilaginous tissue situated over this.

Dentition.-i. $\frac{3}{3}$, c. $\frac{1}{1}$, pm. $\frac{3-4}{2-3}, \mathrm{~m}$. $\frac{3}{3}$; the anterior premolar of the upper jaw and the two anterior ones of the lower are often absent; the upper canines curve round and are directed outwards and upwards, and with those of the lower jaw form formidable weapons of defence.

Dr. Forsyth Major, in a recent revision of this genus, has recognised in addition to the West African Red River hog ( $P$. porcus) and the Madagascar animal ( $P$. larvatus), two additional species from Nyasaland and Abyssinia respectively, as well as two less well defined subspecies of the present form from South Nyasaland and Kilima-njaro. 


\section{Potamochoerus choeropotamus. The Bosch-VARK or Bush Pig.}

Sus africanus, Schreber, Säugeth. v, pl. cccxxvii. (1791) [nec Gmelin] Sus koiropotamus, Desmoulins, Dict. Class. Hist. Nat. xvii, p. 139, pl. 146, fig. 2 (1831).

Sus larvatus, apud Smuts, Enum. Mamm. Cap. p. 59 (1832); A. Smith S. Afr. Quart. Journ. ii, p. 178 (1834) [nec Cuvier].

Choiropotamus africanus, apud Layard, Cat. Mamm. S. Afr. Mius. p. 61 (1861) [nec Gmel.].

Potamochoerus africanus, apud Gray, Proc. Zool. Soc. 1868, p. 34.

Potamochoerus choeropotamus, Forsyth Major, Proc. Zool. Soc. 1897, p. 363 .

Literature.-Moodie (1835), p. 265, on the habits of the bosch-vark; Grout (1863), p. 296, on the habits and native names of the bosch-vark in Natal; Drummond (1875), p. 334, note on occurrence in Zululand; Nicolls and Eglington (1892), p. 78, description and distribution; Kirby (1896), p. 538, on its habits and distribution in the eastern Transvaal; Kirby (1899), p. 334, distribution in Mozambique; Kirby (1899a), p. 526, range and habits.

Vernacular Names.-Bosch-vark of the Dutch Colonists; Ingulube of Amaxosa (Cloete) of Zulus and Swazis (Kirby).

Description.-Body covered with coarse long bristles, thick enough to conceal the skin, the colour of which varies in different individuals from black brown and reddish brown to grey; head with the snout projecting some distance in front of the mouth covered with short white bristles somewhat sparsely disposed so that the bare skin shows in places; usually a black spot on the cheek below the eye; between the eye and the snout a pair of callosities or swellings formed by a cartilaginous thickening of the skin overlying a bony projection of the skull, this is present only in the males and possibly represents a commencing horn; ears rather narrow and pointed with a small pencil of coarse black hairs at the tip; limbs scantily covered with bristles; the false hoofs well developed but pointed, and not ordinarily reaching the ground; tail short and slender with a little brush of black bristles at the tip.

The female has no facial callosities, but the canines are fairly well developed; the young are born with yellow longitudinal stripes.

Skull of the male with a stout backwardly projecting process of the maxillary bone at the root of the canine ending in a roughened surface; a similar roughened surface is placed at the angle between the roof and side of the skull, also on the maxillary bone; on these 
two roughened surfaces lies the cartilaginous nodule forming the callosity; in the female the process is replaced by a narrow longitudinal sharp-edged ridge.

Dimensions.-Of an old mounted male; head and body $4 \mathrm{ft} .3 .5$; tail 12.5 ; height at shoulder 26.0 ; length of hind foot 9.0 ; skull extreme length 14.9 ; incisors to condyle 13.4 ; breadth 6.7 ; length of the upper molar series 4.5 . The length of the lower tushes outside the jaw seldom exceeds 3 inches.

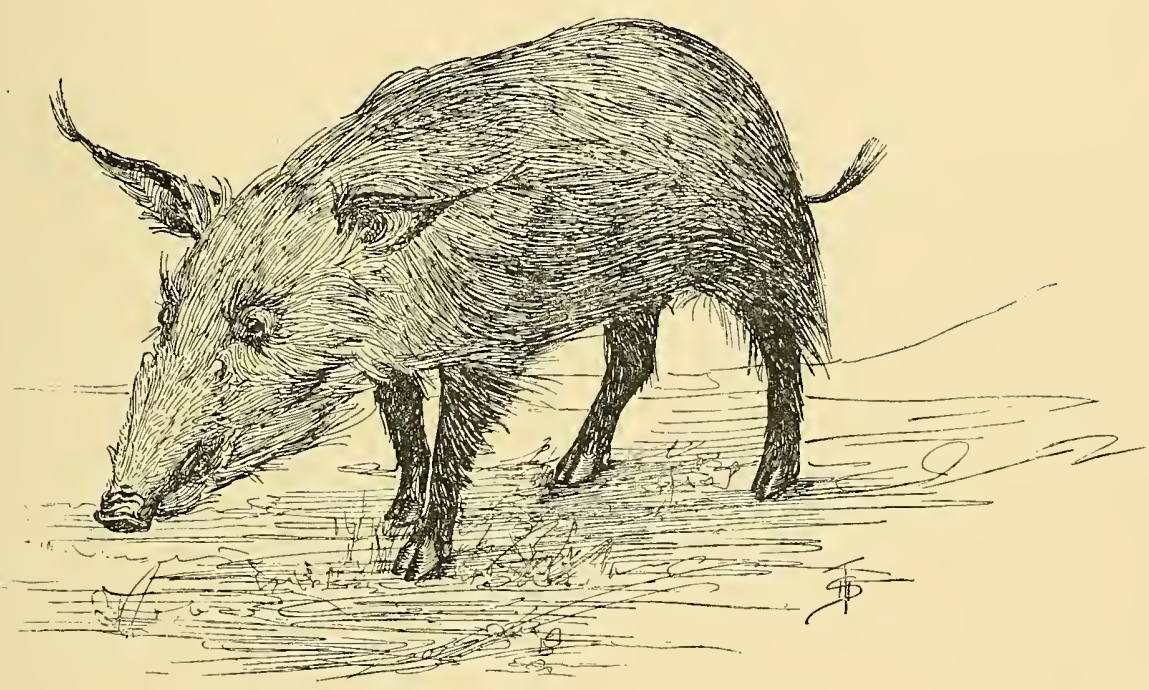

FIG. 69.-The Bosch-vark (Potamochoerus choeropotamus).

Distribution.-The bosch-vark is found chiefly in the eastern and south-eastern parts of Africa, and, according to Dr. Forsyth Major, does not extend north of the Zambesi, the bush pigs of those parts being distinguished by him as separate geographical races.

In the Colony this animal is found along the southern coast in the better wooded districts from Swellendam, whence the South African Museum possesses an example; eastwards through Knysna to the Transkei, Natal, Zululand, and the eastern Transvaal ; though probably occurring in Mashonaland, it does not seem to reach Matabeleland or Bechuanaland. A bosch-vark is said to be found 
in Damara and Ovampoland; possibly this may be of a different species.

History and Habits.-The history of this species is somewhat difficult to decipher owing to confusion with domestic pigs and the wart-hog; the first mention however, seems to be that of Schreber, who in 1791 published a figure of the head without any text. This name, however, cannot hold good, as it is antedated by the same name given to the wart-hog by Gmelin in 1788 ; the earliest name therefore, is the one quoted above in the synonomy.

Bosch-varks are found most abundantly in broken hilly country where there is dense shade and plenty of water; they spend the daytime lying up in thick cover, and in the night they sally forth in bands of from 8 to 10 individuals in search of food, which consists chiefly of roots and wild fruits; when opportunity offers, however, like most pigs they will eat flesh, as is instanced by Kirby in the case of a bushbuck ram wounded and lost by him, which was almost devoured by bosch-varks when again found.

They do great damage to the crops, and are especially fond of green mealies or Indian corn.

They are said never to go to earth, and to always travel with the tail depressed in contra-distinction to the wart-hog. A litter consists of from six to eight, and is produced in December or January. Kirby states that the Hesh is coarse, and never fat, but Grout says they make excellent pork.

This is an animal about which little has been written, as it appears to be seldom seen owing chiefly to its nocturnal habits. Like other wild pigs it is exceedingly plucky; and will come to bay and charge, "dying fighting against all odds, grim and silent to the last."

\section{Genus PHACOCHOERUS.}

Phacochoerus, G. Cuvier, Règ. Anim. 1st ed., i, p. 236

Type. P. aethiopicus.

Head provided with two pairs of cutaneous lobes, or warts, situated on either side of the face.

Dentition much reduced; in the young animal the formula is i. $\frac{1}{3}$, c. $\frac{1}{1}, \mathrm{pm} \cdot \frac{3}{3}, \mathrm{~m} \cdot \frac{3}{3}=36$. As the animal grows older a gradual reduction takes place, until in some of the oldest animals all the 


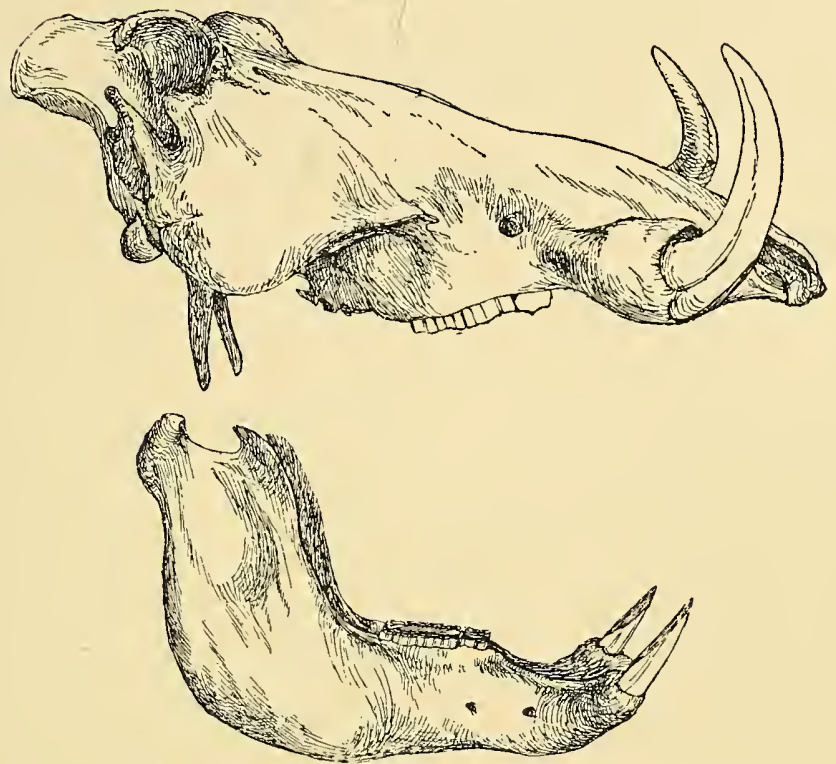

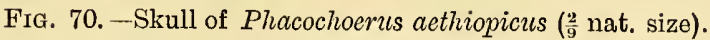

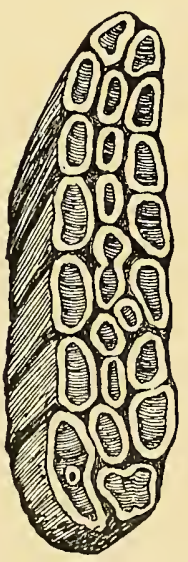

FIG. 71.--Right upper molar of Phacochoerus aethiopicus, 
teeth are lost except the canines and the posterior molars. The upper canines, which are only coated with enamel at their tips, are placed laterally in their sockets and curve outwards and upwards, attaining frequently a length of 10 inches; the lower canines lie directly underneath the upper ones, and though never so long, preserve a sharp edge by attrition, and are alone used as weapons; molars of very remarkable conformation, especially the posterior one, which is very large in old animals, and consists of numerous little columns, or cylinders, each composed of the usual enamel covering, dentine and pulp all joined together into a solid mass by cement. This modification has been brought about by the gradual elongation of the tubercles which cover the surface of the molars of the ordinary pig.

Two species are doubtfully distinguished, the one below described in which the tooth reduction has been most complete, the other $P$. africanus, from Africa generally, in which the incisors of the upper jaw are constantly retained, and which is said to be further distinguished by its longer naked ears and whiskers.

Of four skulls in the South African Museum two from the eastern Transvaal-one an old male, the other young-certainly retain the upper incisors; the other two-one from Damaraland, the other, unfortunately, with no history, have both entirely lost them.

As the material at my disposal does not allow me to make any definite pronouncement on this point, I have included all the South African wart-hogs under the oldest name $P$. aethiopicus.

\section{Phacochoerus aethiopicus. The Wart-hog.}

Aper aethiopicus, Pallas, Miscell. Zool. p. 16, pl. ii (1766).

Sus aethiopicus, Linnaeus, Syst. Nat., 12th ed., iii, p. 223 (1768).

Phacochoerus aethiopicus, F. Cuvier Mem. Mus. Paris viii, p. 450, pl. xxii (1822); Smuts, Enum. Mamm. Cap. p. 60 (1832); P. L. Sclater, Proc. Zool. Soc. 1850, p. 78, pl. xvii [juv.] ; Layard, Cat. Mamm. S. Afr. Mus. p. 61 (1861); Gray, Proc.Zool. Soc.1868, p. 46;

P. L. Sclater, Proc. Zool. Soc. 1869, p. 276 ; id. ibid. 1871, p. 237.

Phascochaerus typicus, A. Smith, S. Afr. Quart Journ. ii, p. 178 (1834). Phacochoerus pallassii, van der Hoeven, Nov. Act. Acad. Leop. Carol. xix, pt. 1, p. 171 pl. xviii. (1839).

Literature.-Vosmaer (1766) figured and described from a living specimen; Buffon (1776), Suppl. iii, p. 86, description from Allamand of the same individual as that described by Pallas; Sparman (1785), ii, 
p. 25, account under the name of "Boschvark" of a wart-hog met with in Uitenhage, and of its habits; le Vaillant (1796), iii, p. 242, figured and described; Harris (1840), figured on pl. xxvii, fig. 1; Cumming (1855), i, p. 184, met this animal near where Kimberley now stands; Grout (1863), p. 296, description and habits with Zulu name; Nicolls and Eglington (1892), p. 77, pl. ix, fig. 32, on its habits and occurrence with a figure of the head; Selous (1893), p. 79, account of the hunting of the individual now preserved in the South African Museum; Bryden (1893), p. 511, on its distribution in South Africa; Millais (1895), pp. 83, 88, note on habits, with a sketch; Kirby (1896), p. 539, habits and native names in the eastern Transvaal; Ward (1896), p. 304, measurements of tushes; Kirby (1899), p. 335, distribution in Mozambique; Kirby (1899a), p. 517, range and habits.

Vernacular Names.-Vlackte-vark of the Dutch; Kaunaba of the Hottentots (Sparman); Inhlovudawana (i.e. little substitute for the elephant) of Zulus (Grout); Indaigazana of Swazis and Inkulubee of Basutos (Kirby); Kolobe of the Bechuanas (Kirby).

Description.-Body black covered with a few scanty coarse bristles only, except along the middle of the back from between the ears where the bristles are thick and upwards of 12 inches long, their colour varying from a black to a pale brown; head almost naked, except on the top between the ears where there are a number of bristles diverging like the rays of a circle, broad, with a not very projecting oval, not round snout; below the eye is the horizontal longitudinal opening of the suborbital gland below which again is the largest of the two pairs of warts, this pair being fleshy and lobular, while the other pair which is situated between the eyes and the tushes is smaller, harder, and more horny; ears shorter, broader, and more rounded than in the bush-pig, with a few hairs along the margins and in the interiors; limbs somewhat slender, with small false hoofs; tail short, quite naked except for the terminal tuft of black bristles.

The female is smaller in every respect and the warts are not nearly so well developed; the teats are four in number. The young one is uniformly coloured, usually reddish-brown and not striped as most young pigs.

Skull differing considerably from that of the bush-pig, being wide and concave between the orbits; the zygomatic arches are very much thickened chiefly by the formation of a large air sinus in the interior; between the tips of the nasals and the premaxillae, are two nodules of bone continuous with the nasal septum which is ossified in the older animals; the palatal view of the sliull is 
largely modified by the expansion formed by the enlarged sockets of the canines and by the great reduction of the premaxillae.

The dentition is noticed above.

Dimensions.--Of a mounted male from Mashonaland in the South African Museum; head and body $4 \mathrm{ft}$. 6; tail without bristles $17 \cdot 0$, with 20.5 ; hind foot 10.0 ; height at shoulder $2 \mathrm{ft} .6$; skull, length condyle to incisors $12 \cdot 75$; greatest length $17 \cdot 0$; breadth 10.0 ; length of posterior molar, the only cheek tooth, 2.15 ; the longest canine in the South African Museum measures 13.0 , of which 10 inches protrude beyond the socket; Ward gives the record at 26.0 in the case of a specimen from Abyssinia and for South Africa $15 \cdot 0$.

Distribution.-The wart-hog, if both so-called species be included, is spread all over Africa from Cape Verd, Abyssinia and Somaliland in the north, southwards; at the beginning of the century it was met with in the eastern half of the Colony by Sparrman, Barrow and Pringle, and in Namaqualand by le Vaillant, but I have been unable to find any record of its occurrence south of the Orange River in modern times. It is not uncommon in Lydenburg, in the western Transvaal, in Mashonaland and Damaraland, whence the South African Museum has received examples, and it is still to be found in Bechuanaland, Matabeleland, Zululand, and the Portuguese territorities.

Habits and History.-This animal was first made known in Europe by the Governor Tulbagh, who sent in 1765, a live example to the menagerie of the Prince of Orange near the Hague, where it was seen and described by Vosmaer, Pallas and Allamand. Sparrman and le Vaillant also met with the animal in its native haunts, and gave adequate accounts of its appearance and habits.

The wart-hog is usually found in fairly open country and never very far from water; it may be observed in the early morning or in the evening in "sounders" rooting like other wild pigs in the plains; during the heat of the day it retires to dense thickets or other cover; when pursued it usually takes to earth, but whether it makes its own earths or adapts those of other animals to its use is uncertain; it has been noted both by Cumming and Kirby, that when taking to its earth it enters stern first so as to be ready to rush out facing the enemy; it is not as a rule seen in large troops but in small family parties, often accompanying herds of zebra and wildebeest.

When pursued it makes off at a good pace holding its tail 
perfectly erect, but with the bushy tip gracefully hanging over like an ear of barley as represented by Millais. When grazing or digging for roots with its long tushes it generally rests on its knees, but it is with the lower tushes which are provided with sharp edges that it defends itself when attacked, and rips up dogs and even horses.

It seems probable that not more than four young ones are produced at a birth, though Kirby has seen sows accompanied by six or eight youngsters; Sparrman states that when molested the parents will carry off the young in their mouths to a place of safety.

The wart-hog has never been hunted with the spear in South Africa, the reason given being that it so quickly takes to earth; all however, are agreed that it is not nearly so plucky or sporting an animal as the Indian wild boar or even as the bush-pig.

Opinions vary considerably regarding the palatability of the wart-hog, some considering its flesh to be dry and tasteless, others comparing it with very excellent pork.

\section{Suborder PERISSODACTYLA.}

This suborder contains at the present time three very distinct families, the Tapirs, the Rhinoceroses and the Horses, of which only the last two are represented within our boundaries. Palaeontology teaches us that these are but the poor surviving remnants of a vast host of animals which flourished on the earth throughout the Tertiary epoch and which if completely reconstructed, would fill up the gaps now so obvious between such externally unlike animals as the swift one-toed horse, the bulky rhinoceros and the timid, harmless tapir.

The following are the chief characteristics of the suborder-middle toe or third digit of both limbs larger than the others and symmetrical in itself ; this may be the only functional toe, or the second and fourth may form a pair subequally developed on either side; skull with nasal bones expanded posteriorly and with an alisphenoid canal; dorso-lumbar vertebrae usually twenty-three, sometimes twenty-two; femur provided with a third trochanter; astragalus with a pulley-like surface for articulation with the tibia and its distal surface flattened and united to a greater extent with the navicular than with the cuboid.

Premolars and molars in a continuous series, all with massive 
quadrate, transversely ridged or complex crowns, that of the last lower molar very commonly bilobed.

Stomach simple, caecum large, placenta diffuse, no gall-bladder, mammae inguinal.

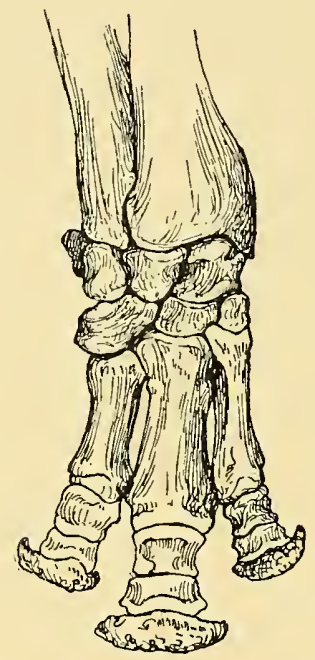

$\Lambda$

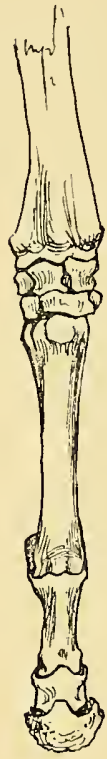

$\mathrm{B}$

FIG. 72.-Skeleton of the right fore-feet of, A, Rhinoceros simus; B, Equus burchelli, to show the modifications of the Perissodactyle limb.

Family EQUIDAE.

Genus EQUUS.

Equus, Linnaeus, Syst. Nat., 12th ed. i. p. 100

Type.

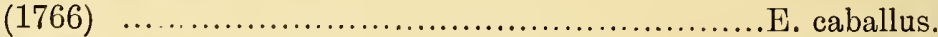

Āsinus, Gray, Zool. Journ., i. p. 244 (1825) ...........E. hemionus. Hippotigris, H. Smith, Jardine's Nat. Libr., xii. p.

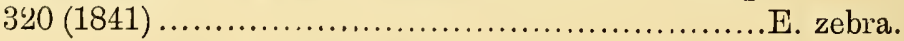

The characters of the family which may for convenience be included in those of the only living genus are as follows :-

Animals of graceful form with limbs adapted for speed; head elongate; a crest or maue of long hairs along the dorsal ridge of the 
neck and long hairs on the tail ; inside the forelegs are a pair of rough callosities, the chestnuts, these are also present on the inside of the tarsus of the hind limbs in the case of the horse ; mammae, two in number, inguinal in position.

Each foot consists of a single digit consisting of a metacarpal or metatarsal bone and three phalanges, the last of which is enclosed
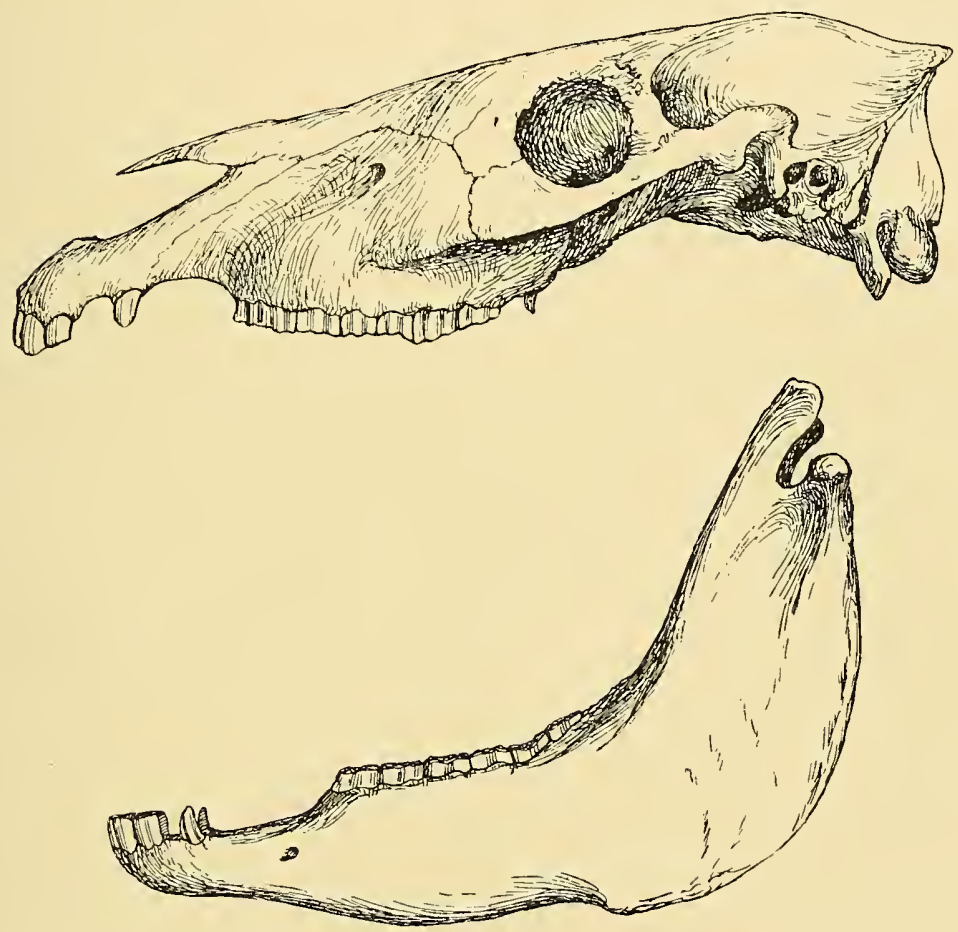

Fig. 73.-Skull of Equus burchelli ( $\frac{3}{16}$ nat. size).

in a horny box, the hoof ; this single digit is the third and the rudimentary metacarpals and metatarsals of the second and fourth digits form the splint bones on either side.

Dentition i. $\frac{3}{3}$, c. $\frac{1}{1}, \mathrm{pm} \cdot \frac{3}{3}, \mathrm{~m} \cdot \frac{3}{3}=40$, the canines are often absent in the females; the incisors have flat crowns with in early life a deep central hollow (the " mark" of horses) which by gradual wear disappears with age; molars and premolars hypsodont (i.e., 
with long crowns and short roots) flattened at the top with very complicated enamel folds. An extra premolar in front of the others is often present and is always a well-developed tooth in extinct allied genera.

This genus contains the horses, wild asses and zebras now confined to central and southern Asia and Africa, but formerly more widely spread over Europe and the whole of America. Within our area only animals belonging to the hippotigrine or zebra section occur; these are distinguished by their beautiful and remarkable stripe-markings.

\section{Key of the South African Species.}

$A$. Stripes covering the greater part of the body, ground colour ochre yellow to pure white.

a. Hairs along the haunches and withers reversed; a gridiron pattern of transverse bars on the haunches; no forelock on the forehead ........

b. Hairs along the haunches and withers not reversed; haunches covered with longitudinal bars, the bent continuations of the body stripes; a forelock present.......................
ipes only on the anterior half of the body, $B$. Stripes only on the anterior half of the body,
ground colour rufous yellow to chestnut, legs and belly pale, almost white

E. zebra, p. 284.

E. burchelli, p. 287.

E. quagga, p. 294.

\section{Equus zebra. The Mountain Zebra.}

Equus zebra, Linnaeus, Syst. Nat., 12 th ed., i, p. 101 (1766); F. Cuvier, Hist. Nat. Mamm. livr. 56 (1826) ; Smuts, Enum. Mamm. Cap. p. 64 (1832); A. Smith, S. Afr. Quart. Journ. ii, p. 181 (1834); Matschie, Zool. Gart. xxxv, p. 36 (1894); Pocock, Ann. Mag. N.H. (6), xx, p. 36 (1897).

Equus montanus, Burchell, Travels, i, p. 139 (1822); Buckley, Proc. Zool. Soc. 1876, p. 282 ; 1877, p. 453 [distribution].

Asinus zebra, Gray, Zool. Journ. i, p. 248 (1825); id., Knonvsley Menagerie, p. 72, pl. lvi (1850); Layard, Cat. Mamm. S. Afr. Mus. p. 62 (1861).

Hippotigris zebra, H. Smith, Jardine's Nat. Libr. xii, p. 324, pl. xxi (1841).

Equus hartmannae, Matschie, S. B. Ges. nat. Fr., p. 174 (1898) [German South-west Africa]. 
Literature.-Tachard (1686), p. 90, account of the zebra with plate; Kolben (1731), ii, p. 112, described as the wild ass; Edwards, Gleanings (1758), v, pl. ccxxii, figured as male zebra ; Buffon (1764), xii, p. 1, pls. i, ii, description of this species under the name of zebra; Sparman (1785), $\mathbf{i}$, p. 137, occurrence in the Caledon division; Barrow (1801), i, p. 93, note on the distribution; Burchell (1822), i, p. 139, ii, p. 273, notes on the distinguishing points of the mountain zebra and record of its occurrence in Bechuanaland; Harris (1840), figured on pl. xxiv, fig. i ; Chapman (1868), ii, pp. 318, 333, notes the existence of mountain zebras in Damaraland, inland from Walfisch Bay; Bryden (1889), p. 99, devotes a chapter to the habits and distribution of the zebra in Cape Colony, illustrated with a photograph of a recently captured individual; Nicolls and Eglington (1892), p. 74, pl. x, fig. 36, description and distribution; Schönland, Nature, xlvi (1892), p. 7, note on existence in Cradock mountains and of its invisibility in its natural haunts; Bryden (1899a), p. 92, range and habits.

Vernacular NAMEs.-The name zebra now in general use appears to have first been generally made known by Buffon and was adopted by him from its vernacular name in the Congo region as stated by some of the older travellers, such as Drack ("Voyage de Fr. Drack," Paris, 1641, p. 106), and de Galline et de Charby ("Relation d'un voyage de Congo," Lyons 1680, p. 76); Wildepaard of Dutch Colonists (Sparrman); Dauw of the Hottentots (Burchell).

Description.-General shape somewhat ass-like; body, head, and limbs closely covered with black or almost black stripes broader than their white interspaces; on the face the dark markings below the eyes become reddish passing into large nostril patches of the same colour, but the muzzle itself is black; no trace of a forelock on the forehead; ears long and rather narrow, posteriorly the basal two-thirds striped, the terminal third black, the extreme point white; mane from between the ears to the shoulders not very well developed, coloured black and white in accord with the body stripes; longitudinal dorsal stripe only noticeable over the haunches, transverse stripes of the barrel extending back over the haunches to the base of the tail forming here the so-called gridiron pattern; no shadow stripes; hairs along the back to the shoulders reversed; belly white, except for a longitudinal dark band running along its anterior portion which is never reached by the transverse body stripes; limbs transversely marked down to the hoofs, the black predominating and the lower portion, i.e., the pasterns, being quite black, chestnuts large measuring about 3 by 2 in.; hoof rather narrow, compact and solid; tail reaching the hocks with a median black line and traces of transverse bars at the base; the distal quarter with a tuft of long black hairs. 
Dimensions.-From a mounted male; head and body $7 \mathrm{ft.} 4$, tail $14 \cdot 0$, with terminal hairs 23 ; height at the shoulders $48 \cdot 0$ (i.e., 12 hands); from ear opening to nose-tip $20 \cdot 5$, ear from notch $7 \cdot 5$; a large female skull measures 20.75 in length from incisors to condyle, and 8.0 in breadth.

Distribution.-The mountain zebra though reduced in numbers is still to be found throughout the greater part of the Colony where suitable mountain ranges are found; it is stated to exist in the Cedarberg in Piquetberg, the Roggeveld in Sutherland, the Swartberg between Prince Albert and Oudtshoorn, the Sneeuwberg in Graaff Reinet, the Winterhoek in Uitenhage, and the mountain ranges of the Cradock and Catheart divisions; the South African Museum possesses a mounted pair acquired in 1897 from Cradock.

Beyond the Colony the mountain zebra has often been stated to occur in German South-west Africa and recently Herr Matschie has described this Damaraland form as a new species under the name of Equus hartmannae from specimens sent to him from the extreme northern part of the German territory known as Kaokoland.

Herr Matschie distinguishes his new species by the following points :-

1. The Kaokoland zebra has 15 longitudinal stripes on the forehead against 20 in the true zebra.

2. The second pale band across the thigh is as wide as its two adjoining dark bands in the Kaokoland form, while much narrower in the true zebra.

3. In the Kaokoland zebra the dark stripes are dark chocolate, not black, and the light stripes are ochre-yellow, not white.

An examination of the mounted specimens in the South African Museum from Cradock shows that the number of longitudinal stripes on the forehead is 13 on the male, 15 on the female individual, that the pale band on the thigh is certainly a little narrower than the neighbouring dark bands, and that the pale ground colour is by no means white, that it is quite ochre tinted along the sides, becoming nearly dead white on the belly, and that the dark stripes can hardly be described as black, being a very dark chocolate brown.

Thus two out of the three differences between the Kaokoland and the mountain zebra break down, while the third is hardly worth consideration.

Under these circumstances we may conclude that $E$. hartmannac is identical with $E$. zebra, and extend the range of the species to the northern part of German South-west Africa. 
History.-Père Tachard, the Jesuit, who visited the Colony in 1685, saw and described a zebra and gave a very poor figure of it, though the animal was first known from the Congo region, where a different species occurs; Kolben described it as a wild ass and also very incompletely; Buffon's description was drawn up from a living specimen in the Menagerie at Versailles, in 1761. Burchell, although he clearly distinguished the three species of zebra which he met with, considered that Linnaeus' name was more rightly applicable to the species subsequently named after himself, and so gave to the present species the name "montanus." In modern times, little has been added to our knowledge of this interesting form, perhaps Bryden's account sums up best most of what is known.

Habits.-As before remarked, the zebra is entirely confined to the most inaccessible portions of the mountains, where it runs in herds of from seven to ten individuals, one of whom is usually posted as a sentinel and gives the alarm with a shrill neigh; it is generally considered to be untamable, though formerly many were said to be exported to Mauritius for draught purposes. Both Bryden and Barrow give instances of the ferocity of the zebra, which apparently attacks with its teeth anyone approaching sufficiently near.

\section{Equus burchelli. Burchell's Zebra.}

This species is a wide-spread one reaching from north of the Orange River to Masailand in British East Africa; throughout its range it varies in a very remarkable manner both in colour and in the arrangement of the markings.

Even in the same herd a good deal of variation has been noticed by people who have had an opportunity of examining a considerable number of these animals together.

Of recent years Pocock and Matschie have shewn that Burchell's zebra may be split up into a number of geographical races, separated from one another by the amount of leg striping, the presence or absence of shadow stripes between the dark bands, and by other characters.

The following key will shew the most salient points of difference between the South African races, but it must always be remembered that the characters given for geograpkical races or sub-species only apply to very typical numbers of the group and that many intermediate forms are likely to be met with. Following a descrip- 
tion of the sub-species will be given a general account of the habits of the species. The characters distinguishing Burchell's zebra in its widest sense from the other species of the genus are as follows :Hairs along the back not reversed; ears short; hoofs broad; no gridiron pattern on the haunches, which are crossed by the backward continuation of the barrel stripes bent at an angle, and so becoming almost longitudinal; the ground colour varies from white to pale ochre and the stripes cover the whole of the head and body as far as the haunches at least.

\section{Key of the Sub-species.}

A. Barrel stripes not reaching the ventral longitudinal stripe.

a. Legs white and unstriped from their junction with body.

E. b. typicus, p. 288.

$b$. Legs slightly striped as far as the knees and hocks.

E. b. antiquorum, p. 289.

$B$. Barrel stripes meeting the ventral longitudinal stripe.

a. Shadow stripes extending to neck, where they are very plain, lower portion of legs but slightly marked

E. b. transvaalensis, p. 290.

$b$. Shadow stripes only on quarters, very strong and distinct, fetlocks and pasterns unstriped and unspotted......

c. Shadow stripes on quarters faint and narrow.

$a^{1}$. Stripes on the lower part of the leg showing a tendency to become obliterated, pasterns not continuously black.

$b^{2}$. Legs strongly striped to the hoofs; fetlocks and pasterns continuously black

E. b. valulbergi, p. 290.

E. b. chapmanni, p. 291.

E. b. selousi, p. 291.

d. No shadow stripes ..................... E. b. craushayi, p. 292.

\section{8a. Equus burchelli typicus. Burcheld's Zebra, Typical} VARIETY.

Equus zebra, apud Burchell, Travels i, pp. 139, 420, 451-2 (1822) [nec Linnaeus].

Asinus burchelli, Gray, Zool. Journ. i, p. 247, pl. ix, figs. 1, 2 [animal and hoof] (1825); id. Knowsley Menagerie, p. 72, pl. lv. (1850); Layard, Cat. Mamm. S. Afr. Mus. p. 62 (1861). 
Equus burchelli, Smuts, Enim. Mamm. Cap. p. 65 (1832) ; A. Smith, S. Afr. Quart. Journ. ii, p. 181 (1834); Buckley, Proc. Zool. Soc. 1876, p. 282, [in part]; Matschie, Zool. Gart. xxxv, p. 65, with woodcut (1894); Pocock, Ann. Mag. N.H. (6), xx, p. 39 [with woodeut], (1897).

Equus montanus, apud F. Cuvier, Mammiféres livr. 55 (1826) [nec Burchell].

Equus zebroides, Lesson, Man. Mamm. p. 346 (1827).

Hippotigris burchelli, H. Smith, Jardine's Nat. Lib. xii, p. 329, pl. xxiii (1841).

General ground colour white, stripes black, shadow stripes brown, these in Gray's typical figure extend forwards from the quarters to the neck, while in other specimens they do not go so far forward; none of the barrel stripes reach the longitudinal ventral stripe which is but little marked; nose patches black, limbs quite white, unspotted and unstriped from their junction with the body; tail with a dorsal dark band but no cross-stripes, tuft white.

The type-locality for this species described and figured by Gray appears to have been Grootfontein about halfway between Griquatown and the junction of the Vaal and Modder Rivers, in what is now Griqualand West, at which place Burchell describes the shooting and preparing of a specimen for mounting. This sub-species was apparently found in former days all over the Orange Free State and Griqualand West, and is probably now extinct. There is a young specimen in bad condition preserved in the South African Museum, presented some years ago by Sir George Grey from the Free State; according to Matschie there are examples of this sub-species in the Berlin and Leyden Museums, and, according to Pocock, in the Bristol, Dublin, and Tring Museums, the one in the former being figured by him.

\section{B. Equus burchelli antiquorum. The Damaraland Zebra.}

Hippotigris antiquorum, H. Smith, Jardine's Nat. Libr. xii, p. 327, pl. xxii (1841).

Equus antiquorum, Matschie Zool. Garten xxxv, p. 68 [fig.] (1894); id. S. B. nat. Fr. p. 172 (1898).

Equus burchelli antiquorum, Pocock, Ann. Mag. N. H. (6) xx, p. 42 (1897).

This sub-species differs from the typical Burchell's zebra in that the stripes extend over the quarters and down to the hocks on the 
hind, and knees of the fore feet; furthermore, the tail shows traces of lateral bands and the nose patches are reddish.

The type locality of this sub-species is unknown; Hamilton Smith identified the specimen which he described and figured with the Congoland zebra mentioned by some of the older writers, but there is nothing to show that his specimen came from thence. Matschie, on the other hand, identified a living Damaraland zebra with Hamilton Smith's description and figure, and gives Damaraland and Great Namaqualand as the range of the animal; there is no example of this sub-species in the South African Museum; it appears to be very closely allied to the typical sub-species.

\section{8c. Equus burchelli transvaalensis. The Transvaal Zebra.}

Equus burchelli transvaalensis, Evwart, Veterinarian, lxx, p. 622 fig. 4 (1897).

The essential character of this variety is that the shadowstripes extend forward to the neck and are very distinct throughout; the legs have very narrow black stripes, which seem to almost disappear below the knees and hocks, in fact, except for the shadow-stripes on the neck this race resembles the following Equus burchelli wahlbergi.

The type of the sub-species is apparently a living female zebra obtained in the Transvaal, and now in the possession of Professor Cossar Ewart; a photograph, fig. 4, on p. 617 [not fig. 5 as stated on p. 622 of Professor Ewart's paper] shows the shadow-stripes most distinctly.

\section{D. Equus burchelli wahlbergi. WAHLBERG's ZeBRA.}

Equus burchelli wahlbergi, Pocock, Ann. Mag. N. H. (6) xx, p. 44 (1897).

The essential character of this sub-species is the great development and distinctness of the shadow-stripes which on the quarters are as wide as the principal stripes; on the lower half of the quarters and shoulders the stripes begin to get fainter and further apart as far as the knees and hocks, where they again become strong, ceasing altogether about half-way between the knees and the hocks and fetlocks, below which point there are no dark markings; the barrel stripes meet the ventral stripe; the tail is laterally 
spotted and the tuft is white with a few black hairs; the nose patches are dull tan.

This sub-species is founded on a mounted specimen in the British Museum obtained in Zululand by Wahlberg, and there is another from the same locality in the Tring Museum. It is not represented in the South African Museum.

\section{E. Equus burchelli chapmanni. Chapman's Zebra.}

Equus chapmanni, Layard, Proc. Zool. Soc. 1865, p. 417; P. L. Sclater, Proc. Zool. Soc. 1865, p. 422, pl. xxii ; Matschie, Zool. Gart. xxxv, p. 66 (1894).

Equus bohmi, Matschie, Zool. Gart. xxxv, p. 69 [fig.] (1894).

Equus burchelli chapmanni, Pocock, Ann. Mag. N. H. (6) xx, p. 43 (1897).

In this sub-species the shadow-stripes are faint, and the legs like those of Wahlberg's zebra are weakly and faintly striped, usually down below the knees, but the pasterns and fetlocks are not continuously black. The barrel stripes reach the ventral longitudinal stripe; the nose patches seem to be black and the tail tuft of mixed black and white hairs.

This sub-species is described in a very vague fashion by Layard from information derived from Messrs. Chapman and Baines, and the type does not appear to have been preserved; the type-locality seems to have been in Bechuanaland about half way between Mafeking and the Botletli River in western Bechuanaland; probably the northern Kalahari, Ngamiland, western Matabeleland and the Transvaal will be found to limit the range of this sub-species.

Though not represented in the collections of the South African Museum, I have examined several skins from the Transvaal belonging to the State Museum at Pretoria, which seem to me identical with this sub-species.

\section{F. Equus burchelli selousi. Selous' Zebra.}

Equus chapmanni, Lorenz, Ann. kk. Hofmus. Wien ix. notiz. p. 64 (1894); id. ibid xi, p. 6 (1896) [nec Layard].

Equus burchelli selousii, Pocock, Ann. Mag. N.H. (6) xx, p. 45 (1897).

Equus burchelli zambesiensis, Trouessart, Bull. Mus. d'Hist. Nat., iv, p. 64 [with fig.] (1898).

The most marked characteristic of this sub-species is the strong striping of the legs throughout, the lower part of the fetlock joint 
being black all round above the hoof; inside the legs are striped on the knees and hocks and below, but above these points the insides of the upper part of both fore and hind legs are white; the barrel stripes reach the ventral stripe; the shadow stripes are faint on the quarters; the nose patches are chestnut, and the tail tuft is black with a few scanty white hairs. The type of this species, a mounted specimen in the British Museum, was shot by Mr. Selous on the Hanyani River in Mashonaland; other specimens also obtained by the same collector are in the Tring and South African Museums.

Some zebras brought back by Dr. Holub from Mashupia, the Barotse province between the Chobe and Zambesi Rivers, appear to me to resemble in every respect this sub-species, except for the fact that the upper part of the inside of the leg is said by Dr. Trouessart to be striped in his specimens; until further comparisons are made his sub-species "zambesiensis" may be considered identical with Selous' zebra.

\section{G. Equus burchelli crawshayi. Crawshay's ZeBra.}

Equus.burchelli crawshaii, de Winton, Ann. Mag. N.H. (6) xvii, p. 319 (1896); Pocock, ibid. (6) xx, p. 46 (1897).

This sub-species together with Grant's zebra from British East Africa is specially characterised by the total absence of shadow stripes, in other respects it appears to be closely allied to Selous' zebra ; the legs are strongly striped to the hoofs, both outside and inside, and the pasterns above the hoofs are black; the nose patches are bright tan, the tail is strongly spotted and has a black tuft.

The type locality is the high country to the west of Lake Nyassa, and other examples have been obtained in different parts of British Central Africa; several flat and necessarily imperfect skins of zebras shot in the Beira district by Mr. L. Maclean, examined by me prove to be entirely without shadow stripes, and seem to be referable to the Nyasaland subspecies, which must therefore be included in our catalogue.

Literature, Vernacular names, and habits of Burchell's zebra sensu latissimo.

Literature.-Barrow (1806), p. 410, the differences between the Colonial and Bechuanaland zebras or quaggas, as noticed by Messrs. Truter and Somerville; Burchell (1822), i, pp. 139, 420, 451-2, ii, p. 315, points out 
the distinctive features and wrongfully identifies this species with $E$. zebra of Linnaeus and gives the native names; Harris (1838), pp. 61, 68, met with this species on the Meritsane River near where Mafeking now is ; Harris (1840), figured on pl. v.; Delagorgue (1847), i, p. 365, plentiful in Zululand ; Methuen (1848), p. 145, note on; Cumming (1855), i, p. 144, met with Burchell's zebra in Hay; Livingstone (1857), p. 56, notes that it is always near water; Holub (1882), p. 267, found great herds of zebras near Mafeking in 1873; Bryden (1889), p. 289, discusses the evidence of the existence at any time of this species south of the Orange River; Nicolls and Eglington (1892), p. 74, pl. x, fig. 34, description, distribution and habits; Bryden (1893), p. 500, present and past distribution; Millais (1895), pp. 131, 171, notes on its habits and the methods of catching; Kirby (1896), p. 549, habits and native names in the eastern Transvaal; Bryden (1897), p. 151, chapter on zebras in general; Gibbons (1898), p. 396, distribution in Barotseland; Kirby (1899), p. 338, distribution in Mozambique; Selous (1899a), p. 79, account of habits and range.

Vernacular Names.-Striped or Bonte Quagga, often Quagga alone of the Dutch ; Iqwara of the Amaxosa (Stanford) ; Idube of Zulus and Swazis (Kirby); Makwa of Basutos (Kirby), Peetsee of Bechuanas (Burchell).

Dimensions. - A male mounted example of Selous' zebra measures as follows: head and body $8 \mathrm{ft} .5$; tail $17 \cdot 0$, with hairs 27 ; height at shoulder $4 \mathrm{ft} .3 .5$; from ear to nose 21.5 , ear from notch to tip 6.5 . A skull measures 18.75 in length by $7 \cdot 30$ in breadth.

Habits.-Burchell's zebra is essentially an inhabitant of the open plains, where it is commonly found in small herds of ten to twenty individuals, though far larger numbers may be seen together; with it, living in a kind of commensalism, are geverally found the blue wildebeest and the ostrich, and more rarely the hartebeest and sassaby. The voice of the zebra is described as a sort of hoarse bark, Millais compares it to something between the bellow of a jackass and the bark of an aged collie. The speed of this animal does not seem to be excessive, it can generally be ridden down, and when a troop is hunted it runs in single file, an old male usually leading. It often loses its life in consequence of its great curiosity, turning round and staring at the pursuer and thus offering an easy shot. It drinks once if not twice daily, and is never found very far from water ; Millais states that it approaches the water before daylight with infinite caution owing to its fear of lions to which it often falls a victim, and which frequently lie in ambush by the waterside; after slaking its thirst the troop gallops off with a great clatter as if glad to escape from so dangerous a 
locality. There is no reason why Burchell's zebra should not be domesticated, in fact where it has been attempted it has succeeded very well. In the Field newspaper of March 11th, 1893, there will be found an account of the breaking in and driving of zebras in one of the coaches between Pretoria and Pietersburg; furthermore the Hon. Walter Rothschild had a team in England which he was in the habit of driving.

The Boers of the low veld of the Transvaal capture zebras alive by riding them down, and when alongside of them slipping a noose at the end of a stick over their heads; when thus secured they are soon tamed and follow the waggons of their captors in a most docile manner.

The flesh is generally loaded with a yellow fat, and is very unpalatable to the European, but by the African natives it is regarded as a great delicacy.

\section{Equus quagga. The Quagga.}

Equus quagga, Gmelin, Syst. Nat. i, p. 213 (1788); F. Cuvier, Hist. Nat. Mamm. livr. xxx (1821) ; Smuts, Enum. Mamm. Cap. p. 65 (1832) ; A. Smith, S. Afr. Quart. Journ. ii, p. 181 (1834); Buckley, Proc. Zool. Soc. 1876, p. 281, 1877, p. 453 [distribution] ; Matschie, Zool. Gart. xxxv, p. 38 (1894) ; Pocock, Ann. Mag. N.H. (6) xx, p. 37 (1897) ; Renshaw, Zoologist (4) ii, p. 213 (1898).

Asinus quagga, Gray, Zool. Journ. i, p. 246 (1825); id. Knowsley Menagerie p. 72, pl. liv (1850); Layard, Cat. Mamm. S. Afr. Mus. p. 62 (1861).

Hippotigris quacha et isabellinus, H. Smith, Jardine's Nat. Libr. xii, pp. 330, 332, pls. xxiv, xxv (1841).

Literature.-Edwards Gleanings (1758), v, pl. cexxiii, figured as the female of the mountain zebra; Masson (1776), p. 297, noted as the "opeaagha" from near Algoa Bay between the Zwartkops and Sunday Rivers ; Buffon (1782), Suppl. vi, p. 85, gives the first authentic account of this animal from Allamand under the name of kwagga or couagga; Sparrman (1785), ii, p. 12, met with them in Uitenhage; Barrow (1801), p. 93, met with them in Prince Albert, and gives a short account; Daniell (1805), figured on pl. 15; Lichtenstein (1812), ii, p. 23, found them plentiful in Aberdeen in 1804; Burchell (1822), i, pp. 139, 280, ii, p. 81, points out the distinctive characters, finding them in considerable numbers in Fraserburg and Hanover in 1812 ; Steedman (1835), i, p. 138, gives an anecdote illustrating their ferocity; Harris (1840), figured on pl. ii.; Cumming (1855), i. p. 93, notes the quagga in Colesberg and Hanover; Grout (1863), p. 303, gives the Zulu name and notes the quagga on the Free State-Natal border; 
Bryden (1889), pp. 289, 393, account of their past distribution and history of their extinction; Nicolls and Eglington (1892), p. 76, description and note on extinction; Bryden (1897), p. 178, general account of habits and extinction; Bryden (1899a), p. 72, habits and extinction.

Vernacular Nayes.-Khoua khoua from the bark of the Hottentots, whence Quagga of the Dutch and of general usage.

Description.-Perhaps smaller than the zebra, general colour light brown or pale chestnut on the head, neck and back, becoming somewhat lighter on the rump and quite white on the belly and legs; stripes on the head, neck and anterior part of the body very

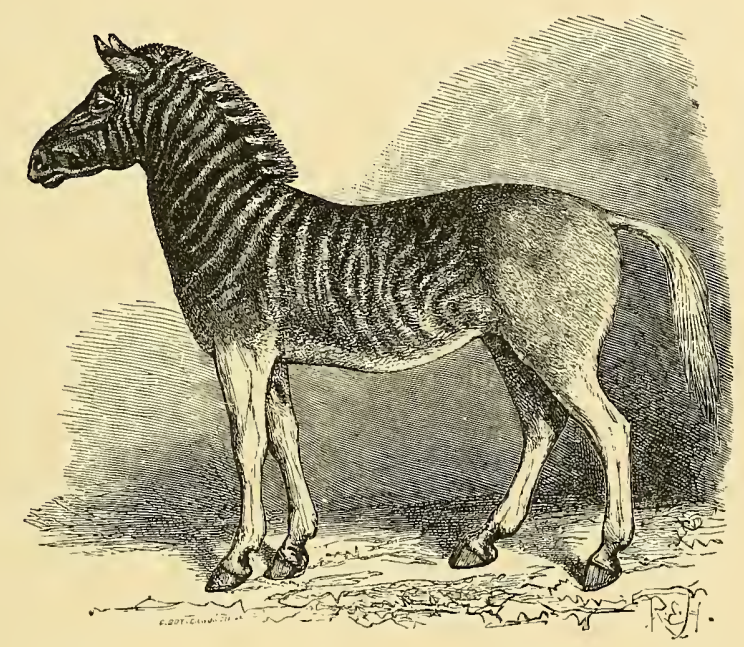

Fig. 74.-The Quagga (Equus quagga).

(Flower and Lydekker).

broad and few in number, separated by very narrow pale yellow interspaces, becoming obsolete beyond the middle of the body, and of a very dark brown colour; dorsal line well marked to the tail; ventral longitudinal stripe also present; limbs pure white with a brown spot just above the hoof; tail and tuft white.

A very young foal preserved in the South African Museum is a good deal darker throughout than the descriptions and coloured plates, and shows no trace of the longitudinal dorsal and ventral lines, this, perhaps, is due to its youth.

Dimensions.-Cuvier gives the height at the shoulder as $3 \mathrm{ft} .9$ 
French (i.e., about 4ft. 1 English), while Harris gives $4 \mathrm{ft} .6$, but Harris's dimensions are generally exaggerated.

Distribution.-The quagga, now without doubt extinct, formerly ranged over the plains of the Orange Free State and the northern and central parts of the Colony; apparently it never extended north of the Vaal River or east of the Kei ; it was very numerous still in the days of Harris and Gordon Cumming, and apparently soon after that became rare in the Colony, where it probably was finally exterminated about 1860 ; Bryden states that the last survivors in the Colony of which he has definite information, were shot at or near Tygerberg in the Aberdeen district in 1858. There is no doubt that they survived a good many years later in the Orange Free State (probably till 1878 at least), but it is difficult to obtain any accurate information on the subject, as in so many cases this and Burchell's zebra are confused together, especially as they were both known under the name of quagga.

The last living quagga in the Zoological Gardens in London was one presented by Sir George Grey in 1858; it survived for six years, dying in June 1864, and it is now mounted for exhibition in the British Museum ; a very young foal, preserved in the South African Museum, came from Beaufort West, and was presented by Mr. A. Dale before 1862, when Mr. Layard's catalogue was published. Other specimens of this now extinct form can be seen in the Edin. burgh and Tring Museums, in England, and in the Paris, Berlin, Frankfort, Mainz, Basle and Berne Museums on the continent.

History and Habits.-As in so many other cases our earliest authentic knowledge of this animal is due to Colonel Gordon's sketches and descriptions transmitted to Allamand, and subsequently reprinted by Buffon.

Before that, however, a living specimen belonging to the Prince of Wales was figured by Edwards in 1751 as the female of the mountain zebra, and the species is also noted by Masson, the botanist, who travelled through the country in 1772; Gmelin's name was founded on Edwards' figure. Among modern authors the best account of this interesting species is to be found in Bryden's works.

Like Burchell's zebra the quagga was essentially an animal of the plains, associating in herds of twenty to thirty individuals, and almost always accompanied by black wildebeest and ostrich, though in the Free State, where both it and Burchell's zebra were found, they were never known to mix. 
Cuvier states that one observed by him in captivity was not fierce but somewhat "méchant" and obstinate, and that on occasions it would use its heels and teeth. A Mr. Sheriff Parkins drove a pair of quaggas at one time early in the century in a phaeton, and was often seen in Hyde Park.

\section{Family RHINOCEROTIDAE.}

\section{Genus RHINOCEROS.}

Type.

Rhinoceros, Limnaeus, Syst. Nat. 12th ed.i, 104 (1766)...R. unicornis. Atelodus, Pomel, Cat. Vert. Foss. bassin superieur de la Loire, p. 78 (1853)...................................... elatus.

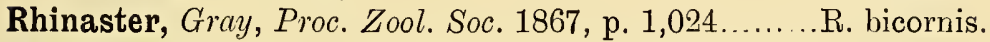
Ceratotherium, Gray, Proc. Zool. Soc. 1867, p. 1,027...R. simus.

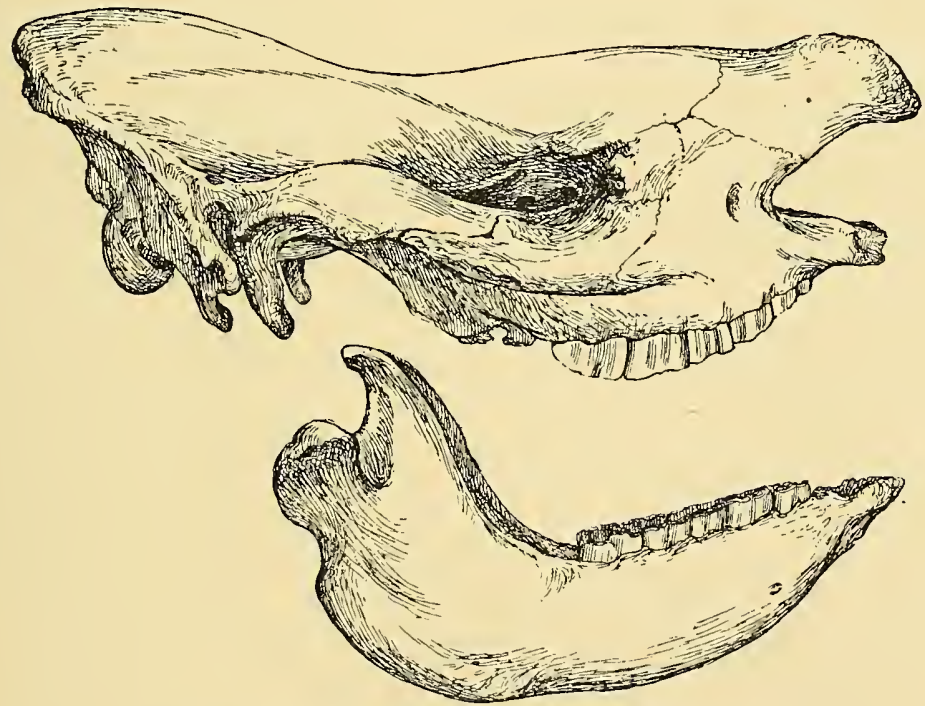

FIG. 75.-Skull of Rhinoceros simus ( $\frac{1}{9}$ nat. size).

This genus contains all the still surviving representatives of the family, and the following are the distinguishing characters.

Animals of large size and of very clumsy build with naked bodies, hairs being found only on the ears and tail; eyes very 
small ; horns composed of a solid mass of epidermic cells, somewhat resembling hairs, but growing from a cluster of free dermic papillae instead of as in true hairs from a sunken follicle; the horns are not in any way attached to the underlying skull, nor does any bony matter take part in their composition; they are one or two in number, and of a more or less conical shape springing from the median line of the skull.

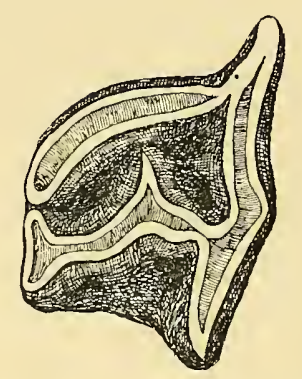

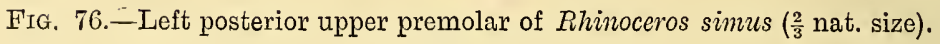

Limbs stout and of moderate length with three well developed toes, each provided with a broad rounded hoof. Skull of large size, elevated posteriorly into a transverse occipital crest; temporal and orbital fossae confluent with no post-orbital process or bar separating them; nasal bones large and stout, co-ossified together and separated from the premaxillae by a wide fissure.

Dentition i. $\frac{2 \text { to } 0}{2 \text { to } 0}$, c. $\frac{0}{1 \text { to } 0} \mathrm{pm} . \frac{4}{4}, \mathrm{~m} . \frac{3}{3}=28$ to 38 ; incisors and canines variable in number, often absent, premolars and molars in a continuous series, and resembling one another in general plan, except that the anterior one is considerably smaller and often deciduous; upper molars with a straight outer edge and a doubly incurved inner edge, so as to form two transverse ridges with a deep valley between; ridges of the lower molars crescentic in shape.

The existing species of the genus are confined to Southern Asia and Africa, and fall naturally into three groups, often considered by zoologists to be worthy of generic separation. These are-

(1) Rhinocerotine group, containing the two one-horned rhinoceroses found in southern India, Burma and the larger Malayan Islands.

(2) Ceratorhine group, comprising the two double-horned species from Assam, Burma, and the Malayan countries. 
(3) Atelodine group, containing the two-horned rhinoceroses, found only in Africa, distinguished by their comparatively smooth skin, by their thick rounded and truncated nasal bones, and by the absence of incisors and canine teeth in the adults.

In the middle and later portions of the Tertiary epochs rhinoceroses were spread over the rest of the Old World, even within the arctic and subarctic regions, where roamed the woolly rhinoceros ( $R$. antiquitatis), considered to be closely allied to the white rhinoceros; hitherto no fossil species have been found in South Africa.

\section{Key of the South African Species.}

A. Larger; with a straight upper lip R. simus, p. 299.

$B$. Smaller; the upper lips provided with a median prolongation or proboscis R. bicornis, p. 303.

\section{Rhinoceros simus. The White or Square-LIPped Rhinoceros.}

Rhinoceros simus, Burchell, Bull. Soc. Philom. Paris, p. 96 (1817); A. Smith, S. Afr. Quart. Joum. ii, p. 179 (1834); id. Illustr. Zool. S. Afr. Mamm. pl. xix (1839); Drummond, Proc. Zool. Soc. 1876, p. 109; Buckley, Proc. Zool. Soc. 1876, p. 280 ; Selous, Proc. Zool. Soc. 1881, p. 725 [distribution]; P. L. Sclater, Proc. Zool. Soc. 1886, p. 143, pl. xvi. fig. 1 [comparison of two species] ; Millais, Proc. Zool. Soc. 1893, p. 614; Coryndon, Proc. Zool. Soc. 1894, p. 329, pl. xviii.

Rhinoceros oswellii, Gray, Proc. Zool. Soc. 1853, p. 46 [fig. of horns]. Ceratotherium simum, Gray, Proc. Zool. Soc. 1867, p. 1027.

Literature.-Parsons, Phil. Trans. (1743) pl. iii, fig. 6, horn figured; Barrow (1801), i, p. 395, supposed occurrence in Namaqualand; Campbell (1822) p. 294, figures head of one shot at "Mashow" in Bechuanaland; Burchell (1822), ii, p. 75, allusion to discovery; Harris (1838) pp. 148, 163, 211, notes on habits and shooting on the Marico and Limpopo Rivers; Harris (1840), figured on pl. xix; Delagorgue (1847), i, p. 366, plentiful in Zululand ; Cumming (1855), i, pp. 248, 338, account of habits and shooting in 1844, with plate of female and young; Andersson (1856), p. 387, recognises and distinguishes the two species, and gives account of habits and distribution; Livingstone (1857), p. 71, notes the straight-horned variety near Lake Ngami; Baldwin (1863), pp. 128, 189, in Amatongaland and Marico in 1856 and 1857; Grout (1863), p. 295, Zulu name; Baines (1864), p. 394, gives a description and measurements of an example killed near Lake Ngami; Selous (1881), p. 81, note on its activity in hill country; Selous (1893), p. 158 account of shooting specimen the head of which is now in 
the South African Museum; Nicolls and Eglington (1892), p. 64, pl, ix, fig. 33, note on approaching extinction; Bryden (1893), p. 490, on past and present distribution; Lydekker (1893), p. 389, description and notes; Oswell in Badminton Big Game, (1894) i. p. 43, notes on the varieties of the white rhinoceros; Ward (1896), p. 288, horn measurements ; Bryden (1897), p. 181, chapter on the natural history ; Selous (1899a), p. 52, range, habits and history.

Vernacular Nayes.---IVitte Phenoster of Dutch hunters; Umkombe of Zulus (Grout); Umhofo of Matabele (Selous) ; Mahohu (Smith) ; Chukuru (Selous) of Bechuanas; Kuabaoba of Bechuanas (Bryden) applied to the variety with the anterior straight horn.

Description.-Larger than the other species, in fact the largest of all land-animals after the elephant, hairless, except for a fringe along the edge of the ear and for the tail bristles; colour not perceptibly lighter than the other species, being a slaty grey black; head very long and massive; upper lip straight all round with no trace of a proboscis; nostril an elongated slit parallel to the mouth; ears longer and more pointed than in the other species, springing from a closed cylinder about three inches long; tail much as in $R$. bicornis, but with only the last quarter provided with wiry bristles.

Female rather smaller than the male, and with two mammae.

The anterior horn is situated on the nasal bones, it is usually longer and more slender than in the other species and curved gently backwards, the upper part of the front being usually partially flattened by friction against the ground; the posterior horn is as a rule short, straight, conical and somewhat laterally flattened; both horns, however, vary a good deal in length and direction, and examples with the anterior horn straight and directed forwards were formerly separated as a distinct species. The skull (see fig. 75 , p. 297), is altogether larger than in the other species, and the portion behind the orbit is drawn out, so that the angle formed at the occipital crest between the parietal and occipital regions is a very acute one ; the front portion, too, of the mandible is much more depressed and spatulated.

Dimensions.-Of a mounted male; head and body $13 \mathrm{ft} .1$; tail 26.0 ; height at shoulder $6 \mathrm{ft} .1 \cdot 5$; Selous gives $6 \mathrm{ft} .6$ for an individual measured by him; ear from notch 9.0 ; ear to nose-tip 35.0 ; a skull of a male measures 30.5 in extreme length from the occipital crest to the tips of the nasals, $27 \cdot 0$ from the condyle to the premaxillae, and $13 \cdot 4$ in the greatest width. 
The horns of the mounted example measure 35.0 and $7 \cdot 0$ respectively, the largest single horn recorded, 62.5, was obtained by the late Roualeyn Gordon Cumming, and is now in the possession of Colonel W. Gordon Cumming; a pair belonging to $\mathrm{Mr}$. Selous measures $37 \cdot 4$ and $17 \cdot 8$ respectively.

History and Yariation.-The square-lipped rhinoceros was met with first of all by Burchell, during his stay in Bechuanaland, though only incidentally alluded to in his account of his journey. In his paper in the Journal of the Philomathic Society of Paris, he speaks of meeting with it first at about the 26 th degree of south latitude, but gives no exact details.

Campbell, one of the early Bechuanaland missionaries, also figures the head of an example brought to him when at Kuruman; the figure is an exceedingly grotesque one, though obviously intended for this species.

Subsequently Harris, Cumming, Andersson and Baldwin, shot very large numbers, until about ten years ago it became exceedingly rare. We owe the greater part of our knowledge of the habits of this now nearly extinct species to Selous, to whom, too, the credit belongs, of having shown, without doubt, that there are only two distinct species of rhinoceros in South Africa. A curious variety considered by Gray to be a distinct species, and named by him Rhinoceros oswellii, is distinguished by possessing a straight anterior horn projecting forward at an acute angle, but this is now acknowledged to be merely an accidental variation.

Distribution.-The square-lipped rhinoceros has never been found south of the Orange River or north of the Zambesi; it was first discovered by Burchell in Bechuanaland, but even in Smith's time (1835), it was driven northwards from the Kuruman neighbourhood, and during the seventies and early eighties, it was practically exterminated in Ngamiland, Matabeleland and Mashonaland, where it had formerly been exceedingly common. The male head preserved in the South African Museum was obtained by Mr. Selous in 1882, between the Bembesi and Sebakwi Rivers, halfway between Bulawayo and Salisbury; Coryndon states that fifteen were shot in Matabeleland in 1886, and he himself shot an old female in 1892, and two males in 1893, the two latter being now in the British and Tring Museums; finally in 1895, Mr. Arthur Eyre shot a fine male north of the Ayrshire mine near Mazoe, in northeast Mashonaland; this specimen was purchased by Mr. Rhodes and presented by him to the South African Museum, where the mounted skin and skeleton are now exhibited. 
There are still said to be a few surviving in Zululand, where they are very strictly preserved, and where, perhaps, they may have a chance of increasing if proper precautions are observed, but even of these, six are said to have been killed in 1894, one of which is now exhibited in the Pretoria Museum.

An imperfect skull is preserved in the South African Museum, which was dug out of the black peaty soil at a depth of eight feet, about twelve miles from the Vaal River in the Kimberley district, in 1893 ; this is the southernmost locality yet recorded.

It is quite possible that this species, or one closely allied to it, may eventually be discovered in Somaliland, but hitherto no authentic accounts or specimens have reached Europe.

Habits.-The square-mouthed rhinoceros is found in open country, and is particularly fond of the wide grassy valleys so frequently met with on the high veld of Matabele and Mashonaland; as a rule they are solitary, or found associating in small parties of two or three individuals, though there may have been a good many in the neighbourhood; Harris, for instance, speaks of seeing eighty in one day. They feed at night, or in the cooler part of the morning and evening, spending the day in sleep as often as not in the open veld under the shade of some solitary tree, but sometimes concealed in thick bush; when thus found asleep they are awakened with great difficulty and can be approached near enough to be photographed; they are very fond of wallowing in pools and plastering themselves all over with clay and mud; like many of the other large thin-haired animals they are constantly accompanied by rhinoceros birds (Buphaga), which feed on the ticks and other parasites lodged on the skin of their host, and give timely warning of any approaching danger; when the rhinoceros is disturbed, and makes off, the birds fly overhead calling and scolding all the time. The pace of the rhinoceros is fairly good considering its bulk; its swift trot will easily surpass man's power but it is, of course, no match for a horse; when it moves, the head is carried very low so that the horn is almost parallel to the ground, and should a mother have a young calf it always precedes her, being guided by the tip of her horn gently pressing on its rump; the food of this species, in contradistinction to the other, consists entirely of grass of which it consumes enormous quantities. It drinks very regularly about midnight, and is never a great distance from water. It has a curious habit of always depositing its excrement at the same place where it accumulates in enormous masses; 
when these have reached an inconvenient height it sometimes demolishes the mass with its horn, moreover, owing to the nature of the food, the animal can always be identified by the composition of the excrement.

Little is known about the breeding habits of this species, the males are said to fight with one another very fiercely at certain times of the year, and only one young one is produced at a birth, the mother, too, exhibits great affection towards her offspring.

The square-mouthed rhinoceros is always spoken of as a most mild and inoffensive creature, very sluggish and unsuspicious; its sight is very bad, though scent and hearing seem to be acute; this no doubt is so, and accounts to a great extent for its almost total extermination, but at the same time it has been known to charge; Oswell, Livingstone's companion had his horse transfixed under him by an enraged individual, though Oswell himself escaped with only a severe shaking.

Selous states that between August and March this animal is in a very good condition, and that the meat is then excellent.

\section{Rhinoceros bicornis. The Connon or Black Rhinoceros.}

Rhinoceros unicornis var. bicornis, Linnaeus, Syst. Nat. 12th ed. i, p. 104 (1766).

Rhinoceros bicornis, Gmelin, Syst. Nat. i, p. 57 (1788); Thunberg, Mem. Acad. Petersb. iii, p. 320 (1811); A. Smith, Illustr. Zool. S. Afr. Mamm. pl. ii (1838); Layard, Cat. Mamm. S. Afr. Mus. p. 61 (1861) ; P. L. Sclater, Proc. Zool. Soc. 1868, p. 529, pl. xli ; Drummond, Proc. Zool. Soc. 1876, p. 109 ; Flower, Proc. Zool. Soc. 1876, p. 455 [revision]; P. L. Sclater, Trans. Zool. Soc. ix, p. 655, pl. xcix, also fig. 7, 8, 9 [heads of 3 vars] (1876); Selous, Proc. Zool. Soc. 1881, p. 725, pl. lxii [horns] ; P. L. Sclater, Proc. Zool. Soc. 1886, p. 143, pl. xvi, fig. 2 ; Flower, Proc. Zool. Soc. 1889, p. 448 [woodeut of 3 horned specimen].

Rhinoceros africanus, G. Cuvier, Règne Anim. 1st ed. p. 240 (1817) ; Smuts, Enum. Mamm. Cap. p. 61 (1832); A. Smith, S. Afr. Quart. Journ. ii, p. 179 (1834).

Rhinoceros keitloa, A. Smith, App. Report Exped. Explor. S. Afi. p. 44 (1836); id. Illustr. Zool. S. Afr. Mamm. pl. i (1838); Buckley, Proc. Zool. Soc. 1876, p. 280 [distribution].

Rhinaster bicornis et keitloa, Gray, Proc. Zool. Soc. 1867, pp. 1024-5.

LiteratURE.-Tachard (1686) p. 90, account of, with illustration ; Kolben (1731), ii, p. 101, a recognisable description of the black rhinoceros ; 
Camper, Act. Petrop. for 1777, pt. 2 (1780), p. 193, pls. v-viii, description of skull sent to author by Governor Baron van Plettenberg; Sparrman in Swedish Academy Transactions (1778), p. 307, gives a description of individuals met with by him; Buffon (1782), Suppl. vi, p. 78, pl. vi, account copied from Allamand; Sparrman (1795), ii, pp. 97, 104, pl. iii, account of specimen obtained by him at Commadagga in Somerset East; Lichtenstein (1812), i, pp. 98, 344, met with rhinoceros in Calvinia and on the little Fish River in 1803-4; Burchell (1824), ii, p. 72, met two in Britstown and gives notes on their habits; Steedman (1835), i, p 69, mentions the occurrence of a specimen on the Great Fish River about 1826; Harris (1838), pp. 84, 103, 158, 278, 376, killed many in Bechuanaland, western Transvaal and Orange Free State; Harris (1840), figured on pl. xvi; Methuen (1848), p. 138, 163, account of the two species and their habits ; Cumming $\cdot(1855)$, i, p. 249, met his first rhinoceros at the head waters of the Marico river in western Transvaal; Andersson (1856), p. 385, account of two species with distribution and habits; Livingstone (1857), p. 56, notes that they are always found near water ; Hall (1857), p. 7, on habits, distribution and distinction; Grout (1863), p. 295, gives the Zulu name; Drummond (1875), p. 72 , devotes a chapter to the shooting and natural history; Theal (1888), i, p. 65 , records the presence of rhinoceroses close to Cape Town in van Riebeck's time [1653], p. 291, gives an account of the upsetting of Simon van der Stel's coach near Piquetberg in 1685, by an individual ; Bryden (1889), p. 286, discusses their extinction in Cape Colony; Nicolls and Eglington (1892), p. 62, pl. x, fig. 35, description and habits; Bryden (1893), p. 489, past and present distribution; Lydekker (1893), p. 386, description and figure; Selous (1893), p. 455, measurements of an individual shot near the Chobe River ; Oswell and Jackson (1894), pp. 43 and 251 in "Badminton Big Game Shooting " reminiscences of shooting; Kirby (1896), p. 550, native names and distribution in Eastern Transvaal ; Ward (1896), p. 284, horn measurements ; Kirby (1899), p. 337, distribution in the Beira-Zambesi district and notes on habits; Kirby (1899a), p. 35, range and habits in South Africa.

Vernacular Names.-Rhenoster or Zwart Rhenoster of the Dutch hunters; Upejani of the Zulus (Grout) and Swazis (Kirby); Umpeygan of the Matabele (Selous); Upelepe of the Basutos (Kirby); Borele of the Bechuanas (Smith). The variety in which the posterior horn is as long or longer than the anterior horn is called Keitloa by the Bechuanas (Smith) and Shangainea by the Matabele (Selous).

Description.-Hairless, except for a fringe along the margins of the ears and on either side of the extremity of the tail; skin almost smooth and very thick; general colour slaty grey, not noticeably darker than the other species; head comparatively short; upper lip with a very distinct median prolongation forming a kind of rudimentary proboscis; nostrils somewhat oval, not elongated; eye very small; ears somewhat funnel-shaped with rounded tips, the 
margins clothed with a fringe of black hair ; limbs solid and massive, each with three broad nail-like hoofs; tail reaching about three quarters of the way to the hocks with a double line of bristles on the posterior two-thirds.

Anterior horn rising from the nasal bones, rounded at the base, where it is often rough and frayed out, so to speak, above becoming laterally flattened and greatly curved backwards, usually exceeding the posterior horn in length; this latter is situated on the frontal bones just above the eye and is usually straight and conical and much inferior in development to the anterior one; but both the horns vary very considerably in shape and size. The skull is much shorter than that of $R$. simus and the angle formed by the parietal and occipital surfaces at the crest is much more nearly a right angle; the front part of the mandible too, is not nearly so depressed and spatulated as in $R$. simus.

As in the other species there are no incisors or canines in either jaw, though indistinct marks of the sockets can be seen; moreover, the premaxillae are much reduced, and consist only of two small nodules of bone at the tips of the maxillae.

Dimensions.-From a mounted specimen; head and body $10 \mathrm{ft}$. 2 ; tail 28.0; height at shoulder $5 \mathrm{ft} .0 .5$; length of ears 7.5 ; from ear opening to nose-tip 25.0 ; 'length of a skull from the tip of the nasals to the occipital crest 22.5 ; from premaxillae to occipital condyle 22.5 ; extreme breadth 12.5 . Average horns measure, the anterior from 18 to $20 \mathrm{in}$. and the posterior from 7 to 8 in. respectively. Ward notices a head from Zululand, of which the anterior horn reached 41.5 , while the posterior was only 10 ; while in another case the anterior was 32.5 , and the posterior 19.0 , these are the longest recorded anterior and posterior horns.

History and Yariations. - This species became known at the time of the first settlement at the Cape in 1653; it is frequently mentioned in van Riebeck's diary, and apparently at that time, was common enough on the slopes of Table Mountain and on the Cape Flats; a further incident corroborating this is, that the coach in which Simon van der Stel, the Governor, was proceeding northwards, on a journey to Namaqualand in 1685, was upset in the neighbourhood of Piquetberg, by the charge of a rhinoceros, and the Governor himself had a narrow escape. Tachard, who spent some few weeks at the Cape at the same time (1685), and Kolben who wrote about fifty years later, both caricature the rhinoceros shamefully in their representations, but the latter gives a very 
amusing description of the animal, in which many fables are mingled with truth; finally, the rhinoceros emerges from myth through the observations of Colonel Gordon transmitted to Allamand, and of Sparrman whose researches were made on a freshly killed individual in what is now the Somerset East division of the Colony.

A variety which appears to be only an accidental one, in which the posterior horn is equal to, or exceeds the anterior one, was long considered a distinct species under the name of $R$. keitloa; that every gradation between the relative size of the two horns is found in nature, and that the distinction is not of specific value, was first proved by Selous in his paper above quoted.

Occasionally, a curious triple-horned variety has been found, one such is described by Flower (op.c.) from near Mount Kilima-njaro in East Africa, in which the third horn forms an unsymmetrical triangular elevation about $5 \frac{1}{2}$ inches high in the median line of the lower part of the forehead.

Distribution.-The common rhinoceros was formerly widespread throughout the whole of South Africa, though now it has been driven out of all the more accessible districts. At the end of the last century it was still common along the south coast of the Colony, Colonel Gordon shot one on the Gamka River, in what is now Oudtshoorn and Sparrman obtained his specimen near the junction of the Fish rivers in Somerset East; according to Hall the last one in the Colony, an old male, was shot in 1853, on the Coega River, close to Port Elizabeth, while in the Orange Free State the last recorded was killed in 1842, at Rhenoster Kop, just south of the Vaal River in the Kroonstad district.

In Harris and Cumming's time (1838-45), rhinoceroses were still quite common in Bechuanaland, but now they are extinct both there and probably also in Rhodesia. In fact at the present time Zululand, the Lydenburg district (where a few are preserved) the BeiraZambesi country and perhaps Ovampoland, seem to be their last haunts south of the Zambesi; beyond our limits the common rhinoceros extends through Nyasaland and East Africa, where in some parts it is extremely abundant to the Upper Nile basin and to Somaliland.

The South African Museum possesses a mounted head and skull obtained in Mashonaland in $\mathbf{1 8 8 4}$ by Mr. Selous, and a complete mounted specimen and skeleton obtained ten years later, also in Mashonaland by Mr. W. Harvey Brown. 
Habits.-The common rhinoceros frequents bush covered country more than the open grass-lands, and is often found in rocky stony districts; it is generally solitary, being of a morose and unsociable disposition, though of course occasionally associating in small family parties; the rhinoceros birds (Buphaga and Textor) are usually in attendance. Like the other species it is nocturnal in its habits, eating and drinking during the night and spending the day in sleep, sometimes in dense thorny thickets, sometimes under the shade of a solitary tree or a large rock in the open plains, generally resting with its stern up wind; in dull cloudy weather, it may occasionally be seen feeding during the daytime, but this is not of common occurrence. The only sounds to which it gives vent appear to be grunts and snorts of rage; when disturbed it makes off in any direction, usually down wind, but after a short way gradually wheels round up wind, its pace being fairly good, better than that of the square-mouthed species; when moving along it holds its head high up, and if a calf is present it follows its mother instead of preceding it.

Its food consists entirely of the leaves, twigs, and sometimes the roots of certain bushes and shrubs, never of grass, and their excrement which they scatter about with their horns and never allow to accumulate, is dark coloured and full of twigs and chips; they drink in the evening and at dawn, often wallowing at the latter time.

During certain seasons the males fight with one auother, but little is known about details of their breeding habits; probably only one calf is born at a time.

The scent and hearing of the rhinoceros is very keen but its eyesight is exceedingly poor ; in disposition it is morose and solitary with coarse and uncouth manner, great irascibility, unbounded curiosity and singular nervous excitability; it is subject to paroxysms of fury when it tears up the ground in great furrows with its horns, and behaves generally in a most whimsical manner.

Much has been written by the earlier writers about the danger of meddling with rhinoceroses, and it is generally stated that they will charge without provocation; Mr. Selous, however, does not consider them to be nearly so dangerous as usually represented, and states that only on one occasion was he ever charged without any reason, and further, he believes that many of the stories are due to the fact that the eyesight of the animal being very poor, it makes mad rushes in one particular direction with the object of escaping, 
not of charging; there can be no doubt, however, that many fatal accidents have occurred through charges of the black rhinoceros, whether pre-meditated or accidental, and that great care should be exercised in approaching either an untouched or wounded animal.

\section{Suborder HYRACOIDEA.}

\section{Family PROCAVIIDAE.}

This suborder contains a single family of somewhat obscure affinities, and is confined to Africa and the south western corner of Asia, Owing to the fact that the membeis of this group show considerable external resemblance to the rodents, they were by the earlier naturalists placed in that order; the first author who carefully examined their internal structure and dental characters was Baron George Cuvier, who believed that they were really most closely allied to the Perrisodactyle Ungulates, and should be placed near Rhinoceros. Subsequent further investigations by Milne Edwards and Huxley, went to disprove this very close relationship, and demonstrated that they really occupied a very isolated position with a general affinity only to the Ungulates. Nor has palaeontology hitherto thrown much light on the origin of this interesting group, though recently a number of fossil forms from the cretaceous beds of the Argentine have been described by Ameghino,* which may be expected later on to clear up the mystery of the relationships of this suborder to the other Ungulates.

The following are the more important characters of the Suborder and Family.

Small or moderate-sized animals with practically no tail, with the three middle toes of the fore foot about equally developed, the outer or fifth much smaller, and the inner or hallux a mere ruaiment; the hind foot with three well developed toes, the fifth being quite rudimentary and the first absent altogether; all the toes end in broad, flat, short nails, except the second digit of the hind foot, the last ungual phalanx of which is deeply cleft at the tip and bears a long curved claw; the dorsal vertebrae are numerous, twentyeight to thirty, of which twenty-one to twenty-two bear ribs; as in other Ungulates there are no clavicles.

Dentition i. $\frac{1}{2}$, c. $\frac{0}{0}, \mathrm{pm} \cdot \frac{4}{4}, \mathrm{~m} . \frac{3}{3}=34$; upper incisors long and

* Ameghino Bol, Inst. Geogr. Argent. XVIII. (1897). 
curved growing from persistent pulps like those of rodents, not flattened and chisel-shaped but prismatic in section and pointed, with no enamel coating on their hinder surfaces, lower incisors straight and somewhat procumbent, awl or gouge-shaped; a considerable space separates the incisors from the cheek teeth; these, both premolars and molars are all contiguous, the anterior tooth being small and generally single-rooted and dropping out in adult skulls; the molar pattern resembles that of the horses and

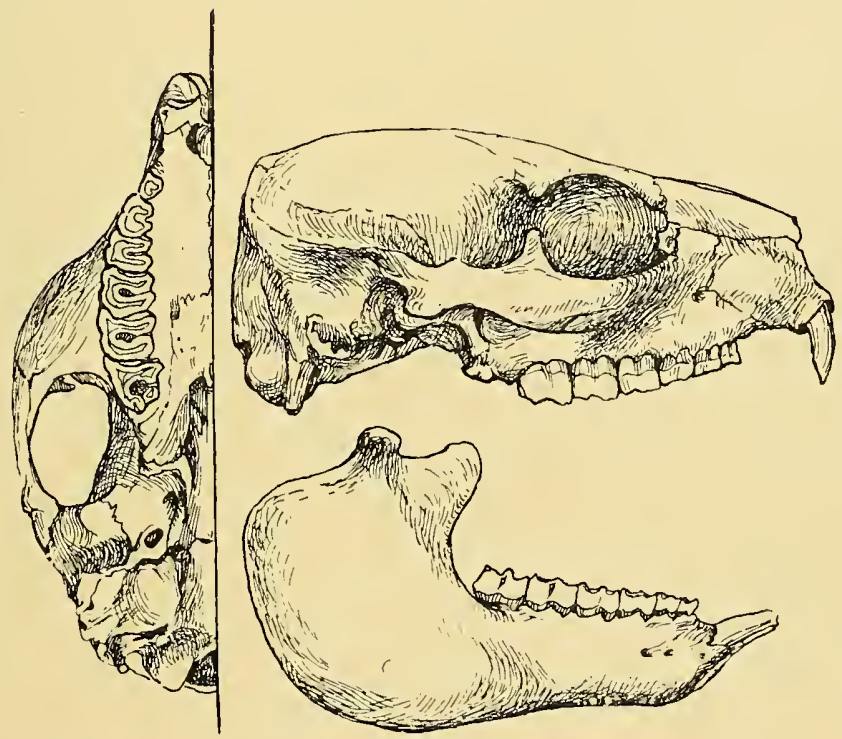

FIG. 77.-Skull, side view, and left half of palate of Procavia capensis.

rhinoceroses; in the upper jaw each tooth has an outer longitudinal and two transverse ridges with a valley between, and in the lower jaw each tooth has a double crescent.

Other special anatomical characters are as follows :-Stomach horse-like; on the intestine some way below the ordinary sacculated caecum usually present in mammals, a pair of large conical-pointed caeca are found quite unique in the mammalian class; no gall bladder to the liver; brain ungulate-like; testes abdominal; placenta zonary. 


\section{Genus PROCAYIA.}

Type.

Procavia, Storr, Prodr. Syst. Mamm. p. 39 (1780) ......... capensis. Hyrax, Hermann, Tab. Aff. Anim. p. 115 (1783) ......... capensis. Dendrohyrax, Gray, Ann. Mag. N.H. (4) i. p. 48 (1868) P. arborea.

The characters of the genus are those of the suborder and family; some twenty different species have been described from various parts of Africa, Syria and Arabia, of which three only have hitherto been definitely recorded from South Africa; it is quite possible, however, that $P$. welwitschi and $P$. bocagii both described from Angola may eventually be found to extend southwards across the Cunene River.

All the animals comprised in the suborder and family resemble one another fairly closely, so that although some writers have formed special genera for the reception of some of the more aberrant species, it seems best to keep them all together under one name.

It is unfortunate that the old and well-established name Hyrax is antedated by three years by Procavia, but if the rules of priority are to be applied at all they must be so in this case, and the more familiar name should be relegated to synonymy.

\section{Key of the South African Species.}

A. Interval between the upper incisors less than the width of the tooth, hairs surrounding the dorsal spot black ...............................

$B$. Interval between the upper incisors at least twice the vidth of the tooth

a. Hairs surrounding the dorsal spot white..... P. capensis, p. 310.

b. Hairs surrounding the dorsal spot yellow. P. arborea, p. 314. P. brucii, p. 315 .

\section{Procayia capensis. The DassIe.}

Cavia capensis, Pallas, Miscell. Zool. p. 30, pls. iii, iv (1766).

Hyrax capensis, Hermann, Tab. Aff. Anim. p. 115 (1783) ; Thunberg, Mem. Acad. Petersb. iii, p. 307 (1811); A. Smith, Descr. Cat. Mamm. S. Afr. Mus. p. 27 (1826); Smuts, Enum. Mamm. Cap. p. 
63 (1832) ; A. Smith, S. Afr. Quart. Journ. ii, p. 180 (1834) ; Read, Proc. Zool. Soc. 1835, p. 13 [habits]; Grill, K. Vet. Alad. Handl. Stockholm, ii, 2, p. 20 (1858); Layard, Ca.t. Mamm. S. Afr. Mus. p. 61 (1861); Zelebor, Novara Reise Säugeth. p. 35 (1864).

Procavia capensis, Thomas, Proc. Zool. Soc. 1892, p. 60.

Anatomy.-In addition to these references the following are entirely concerned with the anatomy of this animal. G. Cuvier, Ann. du Museum, iii, p. 171 (1804); Kaulla, Monographia Hyracis, Tubingen (1830); Owen, Proc. Zool. Soc. 1832, p. 202 ; Martin, Proc. Zool. Soc. 1835, p. 14; Murie and Mivart, Proc. Zool. Soc. 1865, p. 329 ; Brandt, Mem. Acad. Petersb. (7), xiv. no. 2 (1869); Dobson, Proc. Zool. Soc. 1876, p. 526, pl. lv, fig. 9, and figs. A, B ; Lataste, Ann. Mus. Genova (2), iv, p. 5 (1886); Woodward, Proc. Zool. Soc. 1892 , p. 38 , pl. ii.

LITERATURE.-Kolben (1719), p. 144 of German edition, account of, under the name "Daxe"; Vosmaer (1767), description with plate; Buffon (1776), Suppl. iii, p. 177, pl. xxix, described as "Marmotte du Cap"; (1782) Suppl. vi, p. 277, pl. xliii and (1789) Suppl. vii, p. 368, pl. lxxxiv, as "Daman du Cap"; Livingstone (1857), p. 22, on its habits ; Holub (1882), i, p. 305, note on its habits in Bechuanaland; Moseley (1892), p. 124, on habits and occurrence near Simonstown; Kirby (1896), p. 550, native names and habits in the Eastern Transvaal.

Vernacular Nanes.-Rock Rabbit of English Colonists, Das, Dassie, Dasje or Klip-dass of Dutch; Imbila of Amaxosa (Cloete) Swazi and Zulus (Kirby); Ipila of Basuto (Kirby).

Description.-General appearance plump and rabbit-like except for the short ears; colour greyish-brown, the hairs being of medium length, soft and fine, pale to dark sepia in colour for the greater part of their length with dirty white tips, becoming almost white below; head somewhat pointed, the nostril surrounded by a naked rhinarium which is connected with the upper lip by a narrow naked line; ears very short and rounded, posteriorly covered with a thick patch of whitish fur; eyes small, black and very prominent; in the middle of the back is a patch of dark brown or black hairs surrounding a gland with its opening; limbs short and stumpy, the soles naked and black, all the toes ending in broad rounded black nails except the inner one (2nd digit) of the hind foot which bears a curved and twisted claw; no visible external tail; mammae $1-2=6$, i.e., one pair axillary and two pairs inguinal.

Skull with the orbits usually open behind. Upper incisors separated by a space narrower than the width of the tooth, those of the male triangular in section with a sharp ridge in front, those 
of the female much more rounded; lower incisors procumbent, gouge-shaped and in contact in the middle line, diastema short about $\cdot 25$ in.; molars large and hypsodont (i.e., long crowned); as a rule the anterior premolar, which is much smaller than the others and single-rooted, is lost early in life so that only six teeth are present at the same time in both upper and lower jaws.

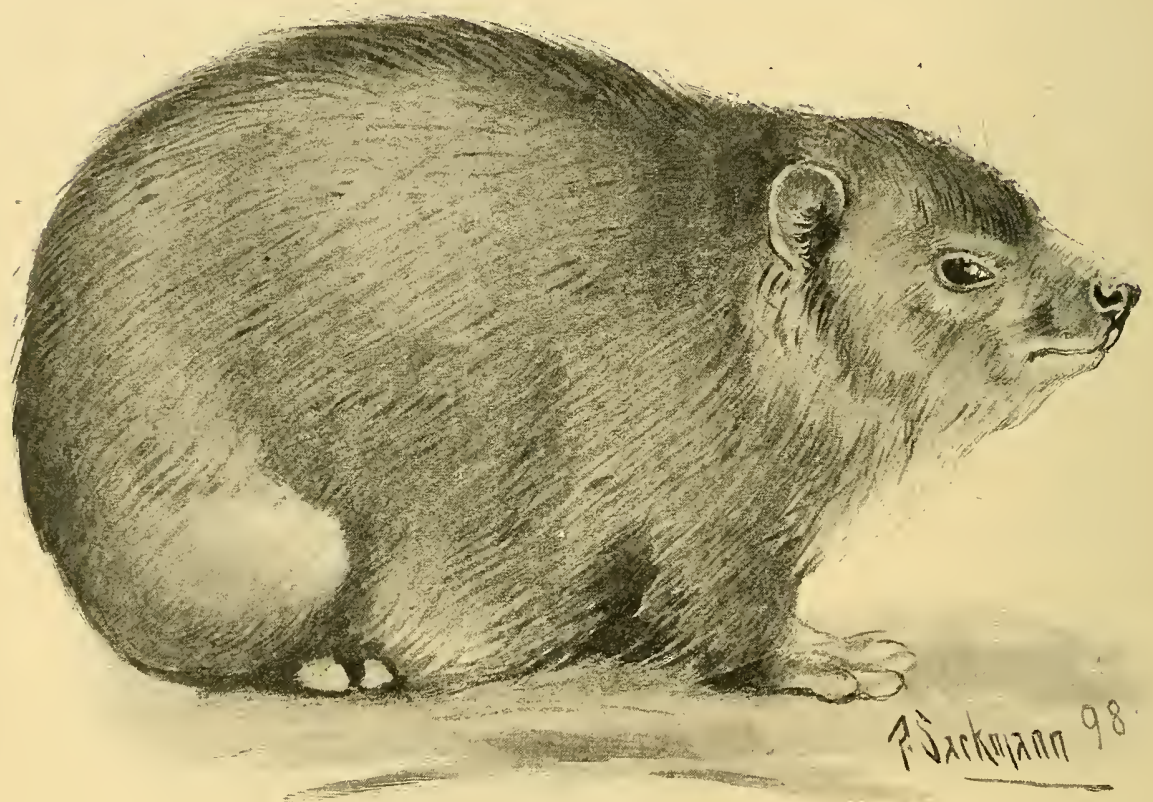

FIG. 78.-The Dassie (Procavia capensis).

Dimensions.-From a mounted specimen; head and body 18 ; hind foot 2.40 ; ear opening to nose tip 3.40 ; height of ear about $1 \cdot 0$; skull length $3 \cdot 20$; breadth $2 \cdot 10$; upper cheek teeth $1 \cdot 60$.

Distribution.-This dassie is found apparently throughout the Colony and Natal and probably extends northwards as far as Rhodesia, but until more examples from different parts of South Africa are collected it is impossible to give its exact limits; the South African Museum possesses examples from the immediate 
neighbourhood of Cape Town, the Paarl, and from near Pretoria. It is quite common on Table Mountain and on the continuation of that range as far as Cape Point.

History.-The earliest allusion to the dassie is doubtless that contained in the Bible (Psalm civ., v. 18) where "the rocks are described as a refuge for the conies," the allusion obviously being to the Syrian species (Procavia syriaca). In South Africa it is first mentioned by Kolben under the name of "daxe" in the original German edition, but the paragraph is not to be found in the English translation. At the end of the last century Pallas, Vosmaer, Allamand, and Buffon all founded descriptions on one or two examples sent alive to Holland by the Governor Tulbagh, and since that time a number of additional species have been described, all of which were carefully revised in 1892 by Mr. Thomas whose arrangement is here followed.

Habits.-The dassie or more correctly dasje (this name is really only the Dutch diminutive for badger, with which of course the present animal has no relationship at all), is found in the rocky cliffs and stony hills which abound all over South Africa; here it lives in small family parties in the crannies and cracks in the rocks but not in burrows excavated by itself. It is very active and has wonderful powers of climbing and clinging to almost perpendicular surfaces; this it is enabled to do by a special arrangement first described by Dobson. The soles, which are naked, are covered by a very thick epithelium which is kept constantly moist by the secretion of the sudorific glands there present in extraordinary abundance; furthermore, a special arrangement of muscles enables the sole to be contracted so as to form a hollow air-tight cup which, when in contact with the rock, gives the animal great clinging power, so much so that even when shot dead it remains attached to almost perpendicular surfaces as if fixed there. The dassie reposes in its lair during the night, feeds mostly in the early morning and evening and spends the middle of the day basking in the sun, at which time, however, it may frequently be seen sitting up on its hind quarters and looking around with a good deal of inquisitiveness; if alarmed it gives vent to a shrill, prolonged cry several times repeated, which somewhat resembles the whistle of a marmot, though described by Moseley as more of a short hissing noise.

Its food consists entirely of vegetable matter, chiefly the young shoots of shrubs. One of the most remarkable babits of this 
little animal is that it deposits its excrement in one particular place, where it may be found collected in large quantities; the renal portion of the deposit generally becomes hardened and forms a black, pitchy mass which is much prized by the natives of South Africa as a drug and, according to Livingstone, is used as an antispasmodic. Little seems to have been observed about the breeding habits of this animal, though Moseley observes that three young ones are the usual number. In captivity they are very clean in their habits and become exceedingly tame and friendly, though always restless and inquisitive; if closely confined they become bad-tempered and savage, frequently biting when they get the chance. Their flesh though dry is edible and somewhat like that of a young rabbit in flavour.

\section{Procayia arborea. The Tree Dassie.}

Hyrax arboreus, A. Smith, Trans. Linn. Soc. xv, p. 468 (1827); Smuts, Enum. Mamm. Cap. p. 63 (1832); A. Smith, S. Afr. Quart. Journ. ii, p. 180 (1834).

Dendrohyrax arboreus, Gray, Ann. Mag. N. H. (4), i, p. 49 (1868).

Procavia arborea, Thomas, Proc. Zool. Soc. 1892, p. 74 [revision].

Literature.-Moodie (1835), ii, p. 192, habits of this species.

Vernacular Name.-Boom or Bosch Dassie of the Colonists.

Description.-General colour dark grey, the hairs dark drabbrown at the bases with lighter tips gradually paling to a dirty white below; head less pointed than in the other species, rhinarium separated from the upper lip by a very narrow band of hair which is broken in the middle by a bare line; ears margined around the edge of the conch by conspicuous white hairs; dorsal gland in the middle of the back surrounded by long white hairs forming a conspicuous white spot; soles naked and yellowish, no external tail, mammae $0-1=2$, i.e., one pair only, inguinal in position.

Skull with the orbits usually closed behind. Upper incisors more slender and separated by a space more than double the breadth of the tooth; lower incisors less procumbent and distinctly separated in the middle line and with tricuspid crowns; molars brachyodont (i.e., short crowned) separated from the incisors by a considerable diastema of over $60 \mathrm{inch}$; as in the other species the small anterior premolar is usually lost before maturity. 
Dimensions.-From a mounted specimen; head and body $17 \cdot 0$, hind foot $2 \cdot 15$; ear opening to nose-tip $3 \cdot 1$; ear about 9 ; skull length $3 \cdot 20$ [imperfect]; breadth 1.90 ; upper cheek teeth $1 \cdot 05$.

Distribution and History.-The species was first described by Sir A. Smith from the eastern portion of the Colony ; from here it extends through Natal probably as far as the Zambesi, but as is the case with the other species, until more material has been collected its exact range cannot be stated ; the South African Museum possesses examples from Albany and Pondoland in the Colony.

Habits.-The only notice of the habits of this species which I have met with is given by Moodie; he states that the boom dassie inhabits hollow trees and runs along the branches with great celerity, and that it gives vent to a clucking noise ending in a prolonged squall often heard in the woods in the early morning.

\section{Procavia brucii. Bruce's Dassie.}

Hyrax brucei, Gray, Ann. Mag. N. H. (4), i, p. 44 (1868).

Dendrohyrax blainvillii, Gray, Ann. Mag. N. H. (4), i, p. 50 (1868).

Hyrax irroratus, Gray, Ann. Mag. N. H. (4), iii, p. 242 (1869).

Hyrax mossambicus, Peters, S. B. nat. Fr. Berlin, p. 25 (1869).

Dendrohyrax bakeri, Gray, Ann. Mag. N. H. (4), xiv, p. 132 (1874).

Procavia brucei, Thomas, Proc. Zool. Soc. 1892, p. 70 [revis.] ; id. ibid. p. 144 (1894) [Nyasaland].

Description.-General colour, grizzled ashy grey, lighter than the Colony dassie; the hairs which are soft and short are slaty at the base, then nearly white, then yellow, then a subterminal band of black, and finally white, the subterminal and terminal bands forming the grizzle; below including the inside of the limbs pure white, sharply distinct from the general colour. Head much the same colour as the back; ears a little paler but not white. Dorsal spot elongate about an inch in length, the hairs round it yellow, a little paler at their bases. Hairs on the toes a little paler than the body but not white; skin of the soles quite black. (Mammae 1-2 = 6 , according to Thomas.)

Skull with fused parietals, and orbits open behind in the only specimen examined. Upper incisors scparated by a space about twice the width of the tooth, lower incisors like those of $P$. arbored with tricuspid crowns and slightly separated in the middle line; diastema of the upper jaw about 60 ; molars brachyodont, and in 
the specimen examined, an adult with the posterior molar well up, the anterior premolar is still present and is double rooted.

Dimensions.-From a somewhat stretched skin, hind foot $2 \cdot 75$, ear opening to nose-tip 4.0 ; ear 1.12 ; skull length 3.55 ; breadth $2 \cdot 10$; cheek teeth $1 \cdot 25$.

Distribution.-This species is found throughout East Africa from Abyssinia to Nyasaland and Mozambique. Two skins with skulls recently obtained in the Mazoe district near Salisbury, in Mashonaland, and presented to the South African Museum by Mr. G. A. K. Marshall, have been compared with specimens in the British Museum, and are doubtless referable to this species, which is thus brought within our limits.

\section{Suborder PROBOSCIDEA.}

\section{Family ELEPHAN'TIDAE.}

This suborder, of which there are only two surviving forms, the Indian and the African Elephant, presents certain very anomalous characteristics distinguishing it very strongly from the rest of the ungulates and showing some points of resemblance to the rodents and to other orders. If, however, the extinct types of the group are studied, we are led back in the earlier Eocene times to a much more generalised form which appears to link the suborder to the rest of the group, and in consequence of this the Proboscidea are here considered as a suborder of the Ungulata rather than as a separate order standing by themselves.

The most noticeable characteristics of these animals are as follows :-Nostrils at the end of a long and flexible proboscis, which has the power of grasping and acts as a hand; limbs strong, feet short, broad and massive, each with five toes encased in common integument with distinct broad short hoofs [not always corresponding in number with the toes]; teeth composed of incisors [i.e., the tusks], of which there are never more than a single pair in either jaw, and transversely ridged molars, the canines being absent. Other characters are: no clavicles, radius and ulna permanently crossed; tibia and fibula complete and distinct, astragalus flat both above and below; hind legs pillar-like, the femur being vertical when standing; two anterior venae cavae return the blood from the 
fore-part of the body to the heart; stomach simple, liver small and simple without gall bladder; caecum large; testes permanently abdominal; uterus bicornuate, placenta zonary and non-deciduate; two mammae, pectoral in position; brain somewhat lowly and primitive, the cerebral hemispheres, although convoluted, not extending over or covering the cerebellum.

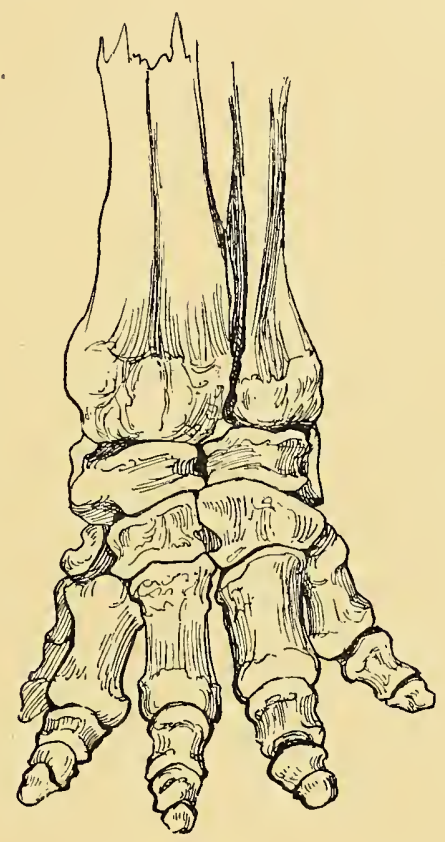

FIG. 79.-Right fore-foot of an African Elephant (Elephas africanus), to show the modifications of the Proboscidean limb.

\section{Genus ELEPHAS.}

Elephas, Linnaeus, Syst. Nat. 12th ed., i, p. 48, (1766) ............................................ indicus.

Euelephas, Falconer, Quart. Journ. Geol. Soc. xiii,

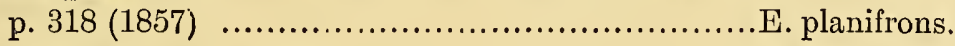

Loxodon, Falconer, ibid E. hysudricus.

Animals of large size with the characters of the suborder given above. 
Dentition i. $\frac{1}{0}$, c. $\frac{O}{0}, \mathrm{dm} . \frac{3}{3}, \mathrm{~m} \cdot \frac{3}{3}=26$; incisors only present in the upper jaw where they reach a very large size, especially in the male; they are directed outwards and downwards in a curve and are composed entirely of dentine, enamel being absent except in the young tooth. The molars consist of milk molars and permanent molars only, as the former are not succeeded by premolars as is usual in most mammals; the six teeth (three milk molars and three permanent molars) in each jaw succeed one another from before backwards, the whole series being gradually forced forward along the jaws, being worn away in front as development proceeds behind. As the teeth are very large, only one or perhaps portions of two are to be found in use at the same time, and the whole succession lasts out the lifetime of the animal.

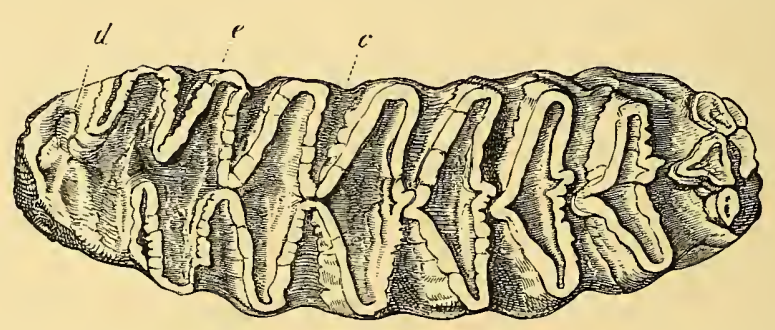

FIG. 80.-Grinding surface of a partially worn right upper molar of the African Elephant (Elephas africanus), to show lozenge-shaped species between the successive enamel plates. $d$, dentine; $e$, enamel ; $c$, cement.

Each molar consists of numerous flattened enamel covered plates of dentine, all surrounded and united by cement right across the crown; the number of plates to each molar is approximately constant but varies with the species.

Skull of the adult very high and globular, all the bones forming the brain case being thickened by the great development of air cells throughout their mass, the brain and brain case being comparatively small ; zygomatic arch with the jugal bone forming the median portion only; nasals extremely short; mandible ending in front in a kind of deflected spout.

In addition to the two well-known recent species a large number of extinct elephants have been described from the later Tertiary beds of Europe, Asia and North America.

Owing to the very considerable differences between the living 
Asiatic and African species many writers have considered that they should be placed in separate genera; should this be done, Loxodon would be the correct generic name for the African species.

\section{Elephas africanus. The Africhn Elephant.}

Elephas maximus, Linnaeus, Syst. Nat. 12th ed. i, p. 48 (1766) [in part].

Elephas africanus, Blumenbach, Handb. Naturges. 6th ed. p. 121, pl. xix, fig. c (1779) ; Thunberg, Mem. Acad. Petersb. iii, p. 320 (1811); Smuts, Enum. Mamm. Cap. p. 58 (1832); A. Sinith, S. Afr. Quart. Joum. ii, p. 176 (1834) ; Grill, K. Vet. Akad. Handl. Stockholm. ii, 2, p. 20 (1858) [Knysna]; Layard, Cat. Mamm. S. Afr. Mus. p. 60 (1861); Buckley, Proc. Zool. Soc. 1876, p. 279, 1877, p. 453; Loder, Proc. Zool. Soc. 1888, p. 87 [large tusks]; Blanc, Bull. Soc. Zool. Fr. xxi. p. 130 (1896) [domestication in classical times]; Mackenzie, Proc. Zool. Soc. 1899, p. 985 [large tusks].

Elephas capensis, G. Cuvier, Tabl. Elem. p. 149 (1798).

Anatony.-Perrault, Mem. Acad. Roy. des Sciences Paris, iii, 3rd part, pp. 101-156, pls. 19-24 (1734); G. Cuvier, Ann. du Mus. viii, p. 120 (1806) [osteology and teeth] ; Mojsisovics Arch. Naturges. lv, pt. 1, pp. 56-92, pls. v-vii (1879); Forbes, Proc. Zool. Soc. 1879, pp. 420-435 [viscera]; Beddard, Proc. Zool. Soc. 1893, pp. 311-315, pl. xxii, xxiii [brain].

Literature. - Tachard (1686), p. 90, notice of occurrence near the Cape ; Kolben (1731), ii, p. 98, a quaint account; la Caille (1763) p. 158, an account of elephant hunting on the Berg River in 1750; Brink and Hop (1778), p. 12, met with elephants just north of the Oliphants River; Sparrman (1785), i, p. 337, relates experiences of elephant hunting in Knysna and discusses their habits; Paterson (1790), p. 62, shot elephants on the south bank of the Orange River; le Vaillant (1796), ii, p. 36, note on a variety without tusks; Steedman (1835), i, p. 62, note on distribution of elephants in the east of the Colony in 1826; Harris (1838), pp. 170, 192, description of shooting in western Transvaal; Harris (1840), figured on $\mathrm{pl}$. xxii ; Delagorgue (1847), i, pp. 366, 454 and 548, account of habits in Zululand; Methuen (1848), pp. 236, 345, dimensions and domestication; Cumming (1855), i, p. 309, account of habits and shooting in Bechuanaland; Livingstone (1857), p. 71, account of large numbers near Lake Ngami in 1849, and further notes and measurements ; Hall (1857), p. 5, habits and distribution; Grout (1863), p. 294, survival in Natal; Chapman (1868), p. 25, met with on the Upper Limpopo; Andersson (1873), pp. 239-386, account of hunting and habits; Drummond (1875), pp. 179-221, account of habits and hunting in Zululand; Selons (1881), pp. 43, 48, 433, various notes on habits, hunting and dimensions; Theal (1888), i, p. 65, ii, p. 7, distribution in the 17th and 18th centuries ; Bryden (1889), p. 286, distribution in Cape Colony ; Nicolls and Eglington (1892), p. 59, distribution and habits; Selous (1893), 
pp. 189, 476, various notes on habits and shooting; Bryden (1893), p. 488, distribution past and present; Oswell and Jackson "Badminton Big Game" (1894) i, pp. 75, 204, shooting reminiscences ; Kirby (1896), p. 9, survival in Lebombo range; Ward (1896), p. 294, tusk measurements; Kirby (1899), p. 339, distribution in the Beira district; Selous (1899a), p. 2, range, habits and shooting in South Africa.

Vernacular Names.-Oliphant of Dutch Colonists; Indhlovu of Amaxosa (Stanford); of Zulus (Drummond); Incubu of Matabele (Nicolls and Eglington); Thloo of Bechuanas (Selous).

Description.-The bulkiest of land animals; body slate-coloured, skin rough, covered with sparse black bristles which, however, are nowhere nearly thick enough to conceal the skin. Proboscis slightly split at the tip so as to form two grasping fingers of nearly equal extent. Forehead evenly rounded and convex not concave; ear's very large and flattened against the shoulders, reaching back to the scapula and down to the top of the foreleg; fore feet with four hoofs only, hind feet with three hoofs, those of the first and fifth digits being absent.

Limbs pillar-like, the upper segments, i.e., the humerus and femur, being much longer than usual, so that the joints corresponding to the "knee" and the "hock" of the horse are close to the ground.

The female is much smaller than the male, has much shorter and slighter tusks, and is provided with two pectoral mammae.

The incisors (tusks) are developed in both sexes, though individuals, more commonly females, are found without any traces of them.

Molars composed of comparatively fewer and larger plates than in the Indian species, the ridge formula of the six successive teeth from before backwards being $3,6,7,7,8,10$, as compared with $4,8,12,12,16,24$ in the case of the Indian species; as the molars wear down the ridges are not quite flattened but are thicker in the middle than at the edges, so that the pattern of the tooth shows a series of lozenges (see fig. 80, p. 318).

Dimensions.-A young female mounted specimen measures as follows; total length from the base of the proboscis to the root of the tail $12 \mathrm{ft}$.; proboscis $5 \mathrm{ft} .3$; tail $2 \mathrm{ft} .4$; height at shoulders $7 \mathrm{ft} .9$; from ear opening to base of proboscis $2 \mathrm{ft} .5$; length of ear $3 \mathrm{ft} .5$; breadth $2 \mathrm{ft} .1$; the skeleton of a male is $8 \mathrm{ft} .2$ in height.

Harris gives $12 \mathrm{ft}$. for the height of a male and $9 \mathrm{ft}$. for that of 
a female; Oswell states that the largest he met with measured 12. ft. 2; on the other hand, males shot by Mr. Selous and his companions never seem to have exceeded $10 \mathrm{ft}$. 4, while Jumbo, the celebrated African elephant so long exhibited in the Zoological Gardens in London was $11 \mathrm{ft}$. in height and weighed $6 \frac{1}{2}$ tons.

The skull of an average male from the Knysna measures from the condyle to the premaxillae $2 \mathrm{ft} .6$ and in breadth $2 \mathrm{ft}$. 3 , while that portion of the tusks. which protrudes beyond the bony sockets just reaches $2 \mathrm{ft}$. 11.

The largest well-authenticated tusks are a pair recently sold at Zanzibar and stated to have been obtained in the Kilimanjaro district; they measured on the outside curve $10 \mathrm{ft} .4 \mathrm{in}$. in length and weighed respectively $235 \mathrm{lbs}$. and $225 \mathrm{lbs}$. There are two good tusks in the South African Museum, one said to be from Stanley Falls in the Congo Free State weighing $158 \frac{1}{2}$ lbs. and measuring $7 \mathrm{ft}$. 1 , another from the Camaroons weighing $137 \mathrm{lbs}$. and measuring $7 \mathrm{ft}$. 3 . The tusks of the female are much smaller and never reach a length of more than 3 or $4 \mathrm{ft}$.

In South Africa elephants never appear to have had such large tusks as in Equatorial Africa; Selous states that the average males' tusks weigh about $50 \mathrm{lbs}$, and females about 10 to $14 \mathrm{lbs}$.

Distribution.-The African elephant is found throughout Africa from Sierra Leone on the west and Abyssinia on the east, southwards to the Colony, but has of course been long driven away from the settled districts, and is now found only in the more inaccessible resorts.

Fossilised remains of the species have been found in Spain, Sicily and northern Africa, in which latter locality it probably existed within historical times, if the writings of Aelian, Pliny, Appian and Plutarch are to be trusted, and if the elephant alluded to by these writers was identical with that of Africa south of the Sahara, a fact on which some doubt has been cast by Blanc.

In South Africa the elephant is now almost exterminate1; within the Colony, however, there are a considerable number in the Knysna and Addo Bush in the divisions of Knysna, Uitenhage and Alexandria. In Zululand, there are a few near St. Lucia Bay; further north in Maputaland, in Zoutspansberg and Gazaland, and in the territory between Beira and the Zambesi they are still to be found in some numbers; there are also said to be some in 
Ovampoland and along the upper reaches of the Okovango and - Chobe rivers.

In the early days of van Riebeck (1653) elephants were plentiful everywhere up to the Cape peninsula, in fact, according to Theal, the last elephant was shot just beyond Cape Flats in 1702 ; the expedition of Captain Hop, in 1761, found plenty just north of the Oliphant River in what is now the district of Clanwilliam, while in the eastern half of the Colony elephant hunting was regularly pursued till about 1830 , and a good many yet remain, as above noticed. In Natal a few survived till 1860; in the north the hunters of the early part of the century made large bags near Kuruman; Harris in $\mathbf{1 8 3 6}$ shot chiefly in the Magaliesberg of the western Transvaal; Gordon Cumming in 1846 in Sechele's country in northern Bechuanaland, and Livingstone and Baldwin, in 1849 and 1858, found elephants innumerable on the Botletli River and near Lake Ngami, and finally Selous' hunting ground in the seventies and early eighties were in what is now Matabeleland and Mashonaland.

The South African Museum possesses a female mounted specimen and a skeleton of a male, both recently obtained in the Addo Bush not far from Port Elizabeth, and a skull of an older individual obtained some years ago in Knysna.

History.-The African elephant was well known in the classical times; the inscription of Adulis near Massowah, on the Red Sea, now destroyed, but of which a copy has been preserved, related how Ptolemy Euergetes (246-221 B.c.) captured Ethiopian elephants and used them for military purposes in his expeditions into Asia beyond the Euphrates as far as Persia, and there can be little doubt that the Carthaginians employed the African Elephant or possibly an allied species from Morocco, against the Romans in the Punic wars. During mediaeval times all accurate knowledge of the African elephant seems to have died out, so much so that Linnaeus believed the African and Indian species to be one. The earliest importation of a living example in modern times appears to have been one which was sent to the King of France by the King of Portugal from the Congo region; it reached France in 1668, and lived there several years, and on its death was dissected by Perrault. Even now-a-days African elephants are by no means common in Europe.

The best accounts of the habits of the African elephant are to be found in the works of Gordon Cumming, Andersson and Selous, as noted above. 
Habits.-The African elephant is not so strictly a forest animal as the Indian species; it is found often in comparatively open tracts and broken country, and often in bush which can hardly cover it when standing up, as for instance in the Addo, which is as a rule only 6 to 8 feet in height. The males, at any rate in the dry season, go about singly or in small bands of six to twenty individuals, while the females with calves and younger males are usually met with in larger bodies up to perhaps in some cases as many as 300 ; in the rainy season, which is the breeding time, the males and females are found associating with one another. In hot weather elephants usually sleep during the middle of the day, generally in a standing position under the shade of a tree, all the while flapping their large ears, probably with the object of driving away insect pests. Gordon Cumming asserts that in out-of-the-way districts they sleep lying on their sides, as was proved to his satisfaction by the impression of the tusks in the ground, this however, is not confirmed by Selous and other later writers. The pace of the elephant is fair, it is never more than a sort of shuffle trot, but a man would have a good deal of difficulty in keeping away from one. Their tread is very soft and inaudible. They travel chiefly at night, and cover incredible distances especially when disturbed. When pressed by the hunter they soon become tired and exhausted, and endeavour to revive themselves by drawing water with their trunks from their stomachs and squirting it over their heads. They ascend and descend steep places with wonderful facility, climbing up with great deliberation but descending very quickly, slipping down with their hind legs bent under them. They also swim very well with their trunks held high above the water and very little of their bodies showing.

The food of the African elephant consists of leaves and twigs, wild fruits, bark and roots, seldom apparently of grass; the older writers state that they plough up the ground in every direction in search of roots with their tusks, but Selous states that the particular root having been located by the trunk, the ground is removed by scraping it away with the forefoot, and that when the root is lain bare it is prized up with the tusks and well chewed for the sake of the sap, the woody portion being rejected.

They feed chiefly during the night and early morning, and when doing so spread out over a considerable tract of country.

Most observers agree that in hot weather elephants drink every night, while in the cooler weather every two or three nights is 
sufficient to satisfy them; they march off at sundown, reaching the water between 9 and 12 o'clock; after drinking and generally wallowing and spouting water all over themselves with their trunks, they return to their feeding grounds.

Very little is known about the breeding habits of the African species, the period of gestation is probably much the same as that of the Indian, i.e., about nineteen months; only one young one is produced at a birth. The calf sucks with the mouth not with the trunk, which is at first very short and not very flexible; the weaning period generally lasts for two years, and the milk tusks are shed at five or six months. Generally speaking, the maternal instinct is not strong, and at a panic the young one is soon deserted, though instances to the contrary have been adduced.

Far the keenest of the elephants' senses is that of smell, which is extraordinarily acute; their hearing is not very good and their sight is distinctly poor. Selous states that at fifty yards an elephant will not distinguish a man from a tree stump. Elephants are naturally exceedingly timid, and have a horror of man, so that " the scent of the smallest baby if conveyed to the olfactory nerves of one of a herd of elephants would put a whole troop to flight." When attacked, the elephant naturally becomes savage and often charges ; most hunters' experience, however, is that a single bullet is sufficient to turn one. All are agreed that the most dangerous and irascible individuals are the tuskless females which are not uncommon.

The African elephant, though much less common in captivity than his Indian cousin, is just as docile and amenable to discipline, although subject from time to time to periodical fits of rage, probably of a sexual nature, as was the case with the celebrated Jumbo so long in the London Zoological Gardens.

The flesh of the elephant appears to be coarse except certain tit-bits such as the heart, the thick part of the trunk, and the fat meat in the hollow just above the eye, all of which were considered as special delicacies by the old-time hunters of South Africa.

END OF VoL. I. 


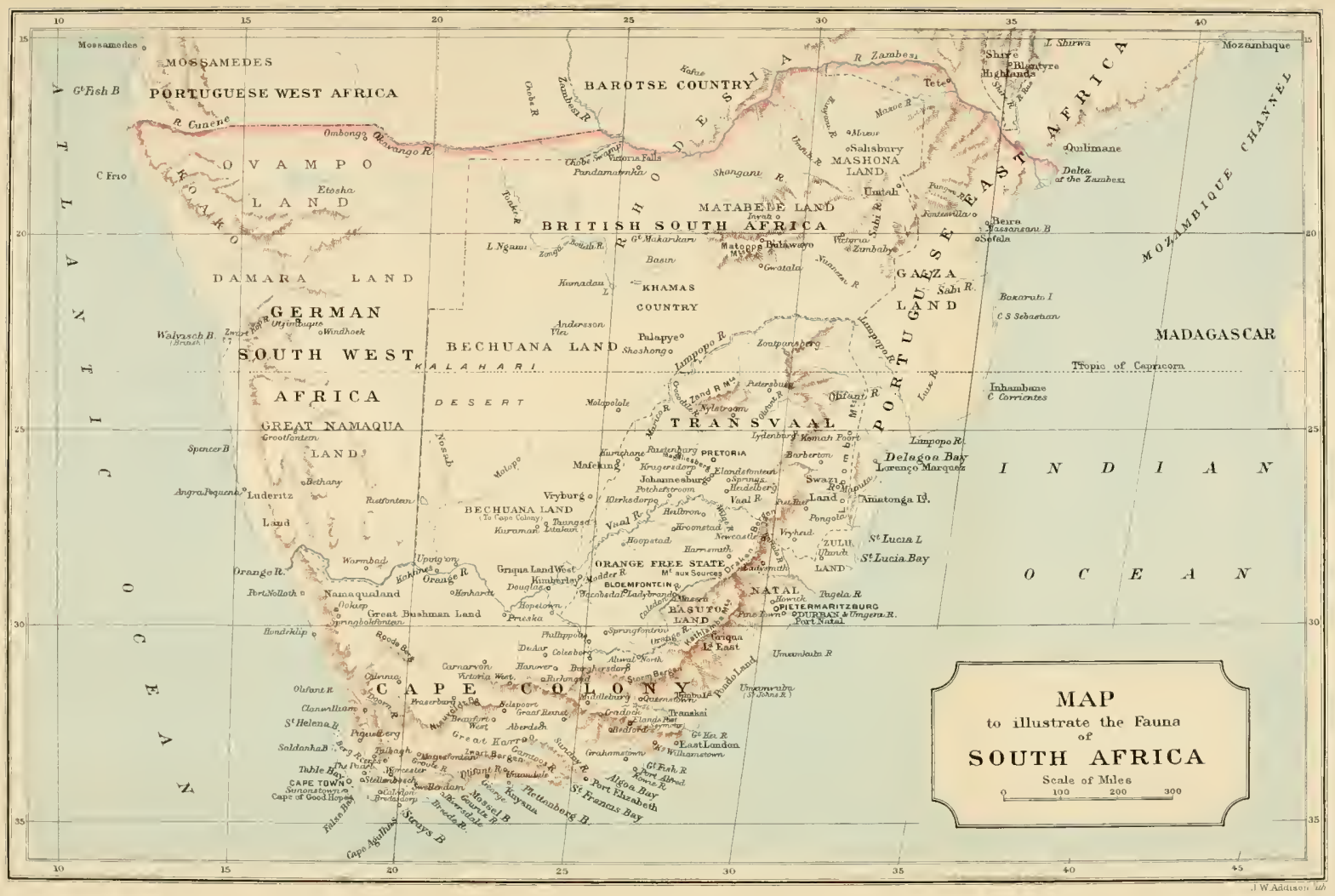






\title{
Boston Public Library \\ Central Library, Copley Square
}

\author{
Division of \\ Reference and Research Services
}

The Date Due Card in the pocket indicates the date on or before which this book should be returned to the Library. Please do not remove cards from this pocket. 

